\title{
Indirect Expropriation in International Law
}

\author{
Rafael Sebastián López Escarcena
}

$\mathrm{PhD}$ - The University of Edinburgh - 2008 


\section{Declaration}

I hereby declare that this thesis has been composed by myself. It is my own work and has not been submitted for any other degree or professional qualification.

Sebastian Lopez Escarcena

March, 2008 


\begin{abstract}
The protection of aliens offers an international minimum standard of treatment. The main interference risked by foreign investors is the expropriation of their property. This may occur in two forms: as an outright taking or as measures having an equivalent effect. Changes in international economics and politics have placed the latter in the centre of legal debate. Indirect takings refer to those measures that are not openly expropriatory, but result in the deprivation of the property of an alien. Identifying the boundaries between them and non-compensable regulatory measures is the chief problem in this area of international law. While the issue is left unsolved by the conceptual analysis of indirect takings, two doctrines provide useful guidelines on it. The first one has been identified as the sole-effect doctrine. According to this position, the central factor in establishing whether an indirect taking has occurred is the result of the host-state measures on the affected property. The second position is the so-called police powers doctrine. Besides the effect on the alien's property, this takes into account the purpose and the context of the respective measures. The present thesis investigates which of these doctrines conform to international law. For that purpose, it studies the protection of the property of aliens in the law of nations, as developed in the different international fora where the issue has been addressed, and the minimum standard of treatment on which it is based.
\end{abstract}




\section{Contents}

Abbreviations viii

List of cases $\quad$ xi

List of treaties and other instruments $\quad \mathrm{XXV}$

1. Introduction 1

2. From compensation to indirect takings 16

2.1. Calvo doctrine and nationalisations $\quad 18$

2.1.1. Against the international standard 20

2.1.2. The road to lump-sum agreements 25

2.2. The law of expropriation at the UN 30

2.2.1. Sovereignty and natural resources $\quad 32$

2.2.2. International economic orders 37

2.3. Changes in economy, politics and treaty-law 42

2.3.1. Investment protection at the turn of a century 43

2.3.2. A shift in the international debate 50

2.4. Conclusion $\quad 54$

3. International human rights law and property 56

3.1. A debated right and its deprivation 58

3.1.1. Inter-American and African approaches $\quad 59$

3.1.2. The European Convention and property 64

3.2. The peaceful enjoyment of possessions 70

3.2.1. Lesser interferences 71 
3.3. Expropriation in the European Convention

3.3.1. Indirect takings and public interest

3.3.2.. Conditions provided for by law

4.1. Takings in an ad hoc forum

4.1.1. Defining property and expropriation

4.1.2. Other measures affecting property rights

4.2. The problem of indirect takings

4.2.1. Constitutive acts

4.2.2. Claims that were rejected

112

4.3. Conditions of legality and their consequence

4.3.2. Compensation and its standard

120

4.4. Conclusion

5.1. Failure and success

5.1.1. Ad-hoc investment treaties

5.1.2. Lawful takings under BITs

5.2. Treaty law, judicial decisions

5.2.1. The expropriation of investments 
6.1. Unsuccessful attempts and soft-law

6.1.1. Early efforts to address expropriation

6.1.2. Guidelines for a lack of agreement

6.2. The US doctrine in international law

6.2.1. Different formulations for different approaches

6.2.2. Replacing the minimum for a maximum

6.3.1. Two rules for one standard

7.1. Changes in international case-law 
7.4. Conclusion

8. Conclusion

250

Bibliography

256 


\section{Abbreviations}

African Commission HPR African Commission on Human and Peoples'

AJIL

ASEAN

BIT

BYIL

Colum. JTN

Colum. $L R$

Corn. ILJ

Corn. $L Q$

Chic. JIL

ECJ

ECOSOC

ECT

Eur. Commission HR

Eur. Court HR

Eur. ELR

Eur. HRLR

EPIL

I/A Commission HR

I/A Court HR

ICSID Rev.

FCN

FET

FTA

FORUM

GATT

Harv. ILJ

Hast. ICLR

ICJ

ICJ Rep.

ICLQ

ICSID

ILC

ILJWP

IL

ILM

ILR

Iran-US CT
Rights

American Journal of International Law

Association of Southeast Asian Nations

Bilateral Investment Treaty

British Year Book of International Law

Columbia Journal of Transnational Law

Columbia Law Review

Cornell International Law Journal

Cornell Law Quarterly (today Cornell Law

Review)

Chicago Journal of International Law

European Court of Justice

Economic and Social Council of the United

Nations

Energy Charter Treaty

European Commission of Human Rights

European Court of Human Rights

European Environmental Law Review

European Human Rights Law Review

Encyclopedia of Public International Law

Inter-American Commission of Human Rights

Inter-American Court of Human Rights

ICSID Review - Foreign Investment Law Journal

Friendship, Commerce and Navigation Treaty

Fair and Equitable Treatment

Free Trade Agreement

International Law FORUM du Droit

International

General Agreement on Tariffs and Trade

Harvard International Law Journal

Hastings International and Comparative Law

Review

International Court of Justice

Reports of Judgments, Advisory Opinions and Orders (ICJ)

International \& Comparative Law Quarterly

International Centre for Settlement of Investment Disputes

International Law Commission

International Law and Justice Working Papers

The International Lawyer

International Legal Materials

International Law Reports

Iran-United States Claims Tribunal 


\begin{tabular}{|c|c|}
\hline Iran-US CTR & Iran-United States Tribunal Reports \\
\hline JDI & Journal du Droit International \\
\hline $\boldsymbol{J} \boldsymbol{J A}$ & Journal of International Arbitration \\
\hline$J P L$ & Journal of Public Law (now Emory Law Journal) \\
\hline JTLP & Journal of Transnational Law \& Policy \\
\hline JWIT & The Journal of World Investment \& Trade \\
\hline LPICT & $\begin{array}{l}\text { Law and Practice of International Courts and } \\
\text { Tribunals }\end{array}$ \\
\hline$L Q R$ & Law Quarterly Review \\
\hline Mercosur & $\begin{array}{l}\text { Mercado Común del Sur (Common Market of } \\
\text { the South) }\end{array}$ \\
\hline MAI & Multilateral Agreement on Investment \\
\hline MFN & Most-Favoured Nation Treatment \\
\hline MLR & Marquette Law Review \\
\hline Mich. JLL & Michigan Journal of International Law \\
\hline NAFTA & North American Free Trade Agreement \\
\hline Neth. ILR & Netherlands International Law Review \\
\hline Neth. YIL & Netherlands Yearbook of International Law \\
\hline NGO & Non-Governmental Organisation \\
\hline NIEO & New International Economic Order \\
\hline Nor. JIL & Nordic Journal of International Law \\
\hline$N w J I L B$ & $\begin{array}{l}\text { Northwestern Journal of International Law and } \\
\text { Business }\end{array}$ \\
\hline NYU ELJ & $\begin{array}{l}\text { New York University Environmental Law } \\
\text { Journal }\end{array}$ \\
\hline NYU LR & New York University Law Review \\
\hline OAS & Organization of American States \\
\hline OECD & $\begin{array}{l}\text { Organisation for Economic Cooperation and } \\
\text { Development }\end{array}$ \\
\hline PCIJ & Permanent Court of International Justice \\
\hline PCIJ Rep. & Collection of Judgments (PCIJ) \\
\hline PTIA & Preferential Trade and Investment Treaty \\
\hline $\mathrm{RdC}$ & $\begin{array}{l}\text { Recueil des Cours (Hague Academy of } \\
\text { International Law) }\end{array}$ \\
\hline $\boldsymbol{R} L \boldsymbol{A A}$ & Reports of International Arbitration Awards \\
\hline SJICL & $\begin{array}{l}\text { Singapore Journal of International \& } \\
\text { Comparative Law }\end{array}$ \\
\hline Tex. ILF & Texas International Law Forum (now Journal) \\
\hline UNCITRAL & $\begin{array}{l}\text { United Nations Commission for International } \\
\text { Trade Law }\end{array}$ \\
\hline UNCTAD & $\begin{array}{l}\text { United Nations Conference on Trade and } \\
\text { Development }\end{array}$ \\
\hline UK & United Kingdom \\
\hline UILR & University of Illinois Law Review \\
\hline UN & United Nations \\
\hline UNGA & United Nations General Assembly \\
\hline UPenn. JIEL & $\begin{array}{l}\text { University of Pennsylvania Journal } \\
\text { International Economic Law }\end{array}$ \\
\hline
\end{tabular}


US

Virg. JIL

Virg. $L R$

Yale LERP

Yale LSDWP

WTAM
United States of America

Virginia Journal of International Law

Virginia Law Review

Yale Law and Economics Research Paper

Yale Law School Draft Working Paper

World Trade and Arbitration Materials 


\section{List of Cases}

\section{PCIJ \& ICJ}

Advisory opinion on the legality or the threat or use of nuclear weapons, ICJ, 8 July 1996. (1996) 35 ILM 809.... Chapter 2

Anglo-Iranian Oil Co. (UK v. Iran), ICJ, Judgment, 22 July, 1952. Available online Chapter 7

Barcelona Traction (Belgium v. Spain), ICJ, Judgment, 5 February 1970. (1971) 3 ICJ Reports.... Chapters $1 \& 7$

Elettronica Sicula, S.p.A. (ELSI) (US v. Italy), ICJ, Judgment, 20 July 1989. (1989) 28 ILM 1138 Chapters 1, 5 \& 7

Factory at Chorzow case (Germany v Poland), PCIJ, Judgment, 25 May 1926. (1926) PCIJ Rep. Series A No 7 Chapter 4

Factory at Chorzow (Germany v Poland), PCIJ, Judgment, 13 September 1928. (1928) PCIJ Rep. Series A No 17 Chapters $1 \& 7$

Mavrommatis Palestine Concessions (Greece v UK), PCIJ, Judgment, 30 August 1924. (1924) PCIJ Rep. Series B No 3. Chapter 2

Military and Paramilitary Activities In and Against Nicaragua (Nicaragua v. US), ICJ, Judgment, 27 June 1986. (1986) 25 ILM 1023. Chapter 5

Oil Platforms (Iran v. US), ICJ, Judgment, 6 November 2003. (2003) 42 ILM 1334. Chapter 5

Oscar Chinn (UK v. Belgium), PCIJ, Judgment, 12 December, 1934. (1934) PCIJ Rep. Series A/B No 63 .Chapters 4 \& 7

United States Diplomatic and Consular Staff in Tehran Case (US v. Iran), ICJ, Provisional Measures, 15 December 1979. (1979) ICJ Rep. Chapter 4

United States Diplomatic and Consular Staff in Tehran Case (US v. Iran), ICJ, Partial Judgment, 14 May 1980. (1980) ICJ Rep. Chapter 4

\section{Human Rights Courts and Commissions}

A, B and Company AS v. Federal Republic of Germany, Eur. Commission HR, No. 7742/76. (1978) 14 Decisions and Reports 146. Chapter 3 
Advisory Opinion OC-10/89 of the I/A Court HR, 14 July, 1989, on the Interpretation of the American Declaration of the Rights and Duties of Man within the Framework of Article 64 of the American Convention on Human Rights. Available online. Chapter 3

AGOSI v. United Kingdom, Eur. Court HR, Series A No. 108, Judgment, 24 October 1986. Available online. .Chapter 3

Air Canada v. United Kingdom, Eur. Court HR, Series A No. 316-A, Judgment, 5 May 1995. Available online. Chapter 3

Akdivar and others v. Turkey, Eur. Court HR, Reports of Judgments and Decisions 1996-IV, Judgment, 16 September 1996. Chapter 3

Almeida Garrett, Mascarenhas Falcão and Others v. Portugal, Eur. Cout HR, Reports of Judgments and Decisions 2000-I, Judgment, 11 January 2000 . Chapter 3

Baner v. Sweden, Eur. Commission HR, No. 11763/85, (1989) 60 Decisions and Reports 128 . .Chapter 3

Belvedere Albergheria S.R.L. v. Italy, Eur. Court HR, Reports of Judgments and Decisions 2000-VI, Judgment, 30 May 2000. Chapter 3

Beyeler v. Italy, Eur. Court HR, Reports of Judgments and Decisions 2000-I, Judgment, 5 January 2000. Chapter 3

Bramelid \& Malmstrom v. Sweden, Eur. Commission HR, Nos. 8588/79 and 8589/79, (1982) 29 Decisions and Reports 64. Chapter 3

Broniowski v. Poland, Eur. Court HR, Reports of Judgments and Decisions 2004-V, Judgment, 22 June, 2004. Chapter 3

Carbonara and Ventura v. Italy, Eur. Court HR, Reports of Judgments and Decisions 2000-VI, Judgment, 30 May, 2000. .Chapter 3

Chassagnou and Others v. France, Eur. Court HR, Reports of Judgments and Decisions 1999-III, Judgment, 29 April, 1999. Chapter 3

Cinco Pensionistas v Perú, I/A Court HR, Series C No. 98, Judgment, 28 February 2003. Available online. Chapter 3

Communications 105/93, 128/94, 130/94 and 152/96, Media Rights Agenda and Constitutional Rights Project v. Nigeria, African Commission HPR, $12^{\text {th }}$ Activity Report 1998-99, Annex V, in R Murray and M Evans (ed), Documents of the African Commission on Human and Peoples' Rights (2001). Chapter 3 
Communications 140/94, 141/94 and 145/95, Constitutional Rights Project, Civil Liberties Organisation and Media Rights Agenda v. Nigeria, African Commission HPR, $13^{\text {th }}$ Activity Report 1999-2000, Annex V, in M Evans and R Murray (eds.), The African Charter on Human Rights and Peoples': the System in Practice, 19862000 (2002). Chapter 3

Comunidad Indigena Sawhoyamaxa v. Paraguay, I/A Court HR, Series C No. 146, Judgment, 29 March 2006. Available online. Chapter 3

Comunidad Indigena Yakye Axa v. Paraguay, I/A Court HR, Series C No. 125, Judgment, 17 June 2005. Available online. Chapter 3

Comunidad Mayagna (Sumo) Awas Tingni v. Nicaragua, I/A Court HR, Series C No. 79, Judgment, 31 August 2001. Available online. Chapter 3

Ekner and Hofauer v. Austria, Eur. Court HR, Series A No. 117, Judgment, 23 April 1987. Available online. .Chapter 3

Fredin v. Sweden, Eur. Court HR, Series A No. 192, Judgment, 18 February 1991. Available online. ..Chapter 3

Gasus Dosier- und Fordertechnik GmbH v. Netherlands, Eur. Court HR, Series A No. 306-B, Judgment, 23 February 1995. Chapter 3

Gratzinger and Gratzingerova v. Czech Republic, Eur. Court HR, Grand Chamber, Admissibility decision, 10 July, 2002. Available online. Chapter 3

Guillemin v. France, Eur. Court HR, Reports of Judgments and Decisions 1997-I, Judgment, 21 February 1997. Available online. Chapter 3

Handyside v. United Kingdom, Eur. Court HR, Series A No. 24, Judgment, 7 December 1976. Available online. .Chapter 3

Hentrich v. France, Eur. Court HR, Series A No. 296-A, Judgment, 22 September 1994. Available online. Chapter 3

Holy Monasteries v. Greece, Eur. Court HR, Series A No. 301-A, Judgment, 9 December 1994. Available online. Chapter 3

Hutten-Czapska v Poland, Eur. Court HR, Judgment, 22 February, 2005. Available online. Chapter 3

I/A Commission HR Res. No. 23/81, Case 2141 (United States), 6 March, 1981. Available online. Chapter 3

I/A Commission HR Res. No. 3/87, Case 9647 (United States), 22 September, 1987. Available online. Chapter 3 
Baruch Ivcher Bronstein v. Perú, I/A Court H.R., Series C No. 74, Judgment, 6 February 2001. Available online. Chapter 3

Allan Jacobsson v. Sweden, Eur. Court HR, Series A No. 163, Judgment, 25 October 1989. Available online

Chapter 3

Jahn and others v. Germany, Eur. Court HR, Judgment, 30 June, 2005. Available online. .Chapter 3

James and others v. United Kingdom, Eur. Court HR, Series A No. 98, Judgment, 21 February 1986. Available online Chapters $3 \& 7$

Kopecky v. Slovakia, Eur. Court HR, Reports of Judgments and Decisions 2004-IX, Judgment, 28 September 2004 .... Chapter 3

Lithgow and others $v$. United Kingdom, Eur. Court HR, Series A No. 102, Judgment 8 July 1986. Available online. Chapters $3 \& 7$

Loizidou v. Turkey, Eur. Court HR, Reports of Judgments and Decisions 1996-VI, Judgment, 18 December, 1996 Chapter 3

Malone v. United Kingdom, Eur. Court HR, Series A No. 82, Judgment, 2 August 1984. Available online. Chapter 3

Marckx v. Belguim, Eur. Court HR, Series A No. 31, Judgment, 13 June 1979. Available online Chapter 3

Matos e Silva Lda. and others v. Portugal, Eur. Court HR, Reports of Judgments and Decisions 1996-IV, Judgment, 16 September 1996. Chapter 3

Mellacher and others v. Austria, Eur. Court HR, Series A No. 169, Judgment, 19 December 1989. Available online. Chapter 3

The National \& Provincial Building Society, the Leeds Permanent Building Society and the Yorshire Building Society v. United Kingdom, Eur. Court HR, Reports of Judgments and Decisions 1997-VII, Judgment, 23 October 1997. .Chapter 3

Papamichalopoulos and Others v. Greece, Eur. Court HR, Series A No. 260-B, Judgment, 24 June 1993. Available online. Chapter 3

Phocas v. France, Eur. Court HR, Reports of Judgments and Decisions 1996-II, Judgment, 23 April 1996. Chapter 3

Pine Valley Developments Ltd and others v. Ireland, Eur. Court HR, Series A No. 222, Judgment, 29 November 1991. Available online Chapter 3 
Pinnacle Meat Processors v. United Kingdom, Eur. Commission HR, No. 33298/96, Admissibility decision, 21 October, 1998, (1998) Eur HR Rep CD 217 Chapter 3

Pressos Compania Naviera S.A. and others v. Belgium, Eur. Court HR, Series A No. 332, Judgment, 20 November 1995. Available online. .Chapter 3

Raimondo v. Italy, Eur. Court HR, Series A No. 281-A, Judgment, 22 February 1994. Available online. Chapter 3

Smith Kline and French Laboratories Ltd v Netherlands, Eur. Commission HR, (1990) 66 Decisions and Reports 70. Chapter 3

Spadea and Scalabrino v. Italy, Eur. Court HR, Series A No. 315-B, Judgment, 28 September 1994. Available online. .Chapter 3

Sporrong and Lönnroth v. Sweden, Eur. Court HR, Series A No. 52, Judgment, 23 September 1982. Available online. .Chapter 3

Stran Greek Refineries and Stratis Andreadis v. Greece, Eur. Court HR, Series A No. 301-B, Judgment, 9 December 1994. Available online... Chapter 3

Stretch v. United Kingdom, Eur. Court HR, Judgment, 24 June 2003. Available online. Chapter 3

Svenska Managementgruppen v. Sweden, No 11036/84, (1985) 45 Decisions and Reports 211. Chapter 3

Travers and 27 others v. Italy, Eur. Commission HR, No. 15117/89, (1995) 80 Decisions and Reports 5 Chapter 3

Tre Traktorer Aktiebolag v. Sweden, Eur. Court HR, Series A No. 159, Judgment, 7 July 1989. Available online. .Chapter 3

Van Marle and others $v$ Netherlands, Eur. Court HR, Series A No. 101, Judgment, 26 June 1986. Available online. .Chapter 3

Velosa Barreto v. Portugal, Eur. Court HR, Series A No. 334, Judgment, 21 November 1995. Available online. Chapter 3

Wasa Liv Omsesidigt v. Sweden, Eur. Commission HR, No. 13013/87, (1988) 58 Decisions and Reports 163 Chapter 3

Wiggins v. United Kingdom, Eur. Commission HR, No. 7456/76, (1979) 13 Decisions and Reports 40 . Chapter 3 


\section{Iran-US Claims Tribunal}

American Bell International, Inc., v. The Islamic Republic of Iran et al, Iran-US CT, Award No. 255-48-3, 19 September, 1986. (1988) 12 Iran-US CTR 170 .Chapter 4

American International Group, Inc. and American Life Insurance Company v. Islamic Republic of Iran and Central Insurance of Iran, Iran-US CT, Award No 93-2-3, 19 December 1983. (1985) 4 Iran-US CTR 96

..Chapter 4

Amoco International Finance Corporation v. The Government of the Islamic Republic of Iran et al, Iran-US CT, Partial Award No. 310-56-3, 14 July 1987. (1988) 15 IranUS CTR 189 .... Chapter 4

Harold Birnbaum v. The Islamic Republic of Iran, Iran-US CT, Award No. 549-9672, 6 July, 1993. (2000) 29 Iran-US CTR 260.

.Chapter 4

Lillian Byrdine Grimm v The Islamic Republic of Iran, Iran-US CT, Award No. 2571-1, 22 February, 1983. (1984) 2 Iran-US CTR 78. Chapter 4

Component Builders, Inc., Wood Components Co. and Moshofsky Enterprises v. The Islamic Republic of Iran, Bank Maskan Iran and Insurance Company of Iran, Iran-US CT, Award No. 431-395-3, 10 August, 1989. (1991) 23 Iran-US CTR

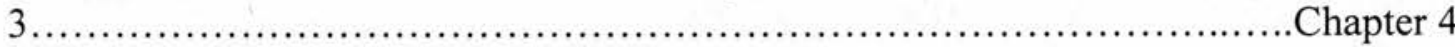

Computer Sciences Corporation v. The Government of the Islamic Republic of Iran et al, Iran-US CT, Award No. 221-65-1, 16 April, 1986. (1987) 10 Iran-US CTR 269. Chapter 4

Leonard and Mavis Daley v. The Islamic Republic of Iran, Iran-US CT, Award No. 360-10514-1, 20 April, 1988. (1989) 18 Iran-US CTR 232. Chapter 4

Dames \& More v. The Islamic republic of Iran et al, Iran-US CT, Award No. 97-543, 20 December, 1983. (1985) 4 Iran-US CTR 212. Chapter 4

Eastman Kodak Company, Eastman Kodak International Sales Co., and Kodak Inc. v. The Government of Iran et al, Iran-US CT, Partial Award No. 329-227/12384-3, 11 November 1987. (1988) 17 Iran-US CTR 153. Chapters 3 \& 4

Shanin Shain Ebrahimi, Cecilia Radene Ebrahimi and Christina Tandis Ebrahimi v. The Government of the Islamic Republic of Iran and National Iranian Oil Company, Iran-US CT, Award No. 560-44/46/47-3. 12 October, 1994. Available online. Chapter 4

Flexi-Van Leasing, Inc., v. The Government of the Islamic Republic of Iran, Iran-US CT, Award No. 259-36-1, 13 October, 1986. (1988) 12 Iran-US CTR 335 . Chapter 4 
Foremost Tehran, Inc. et al v. The Government of the Islamic Republic of Iran et al, Iran-US CT, Award No. 220-37/231-1, 11 April 1986. (1987) 10 Iran-US CTR 228.

Chapters $3 \& 4$

Constantine A. Gianoplus $v$. The Government of the Islamic Republic of Iran, Iran-US CT, Award No. 237-314-1, 20 June, 1986. (1988) 11 Iran-US CTR

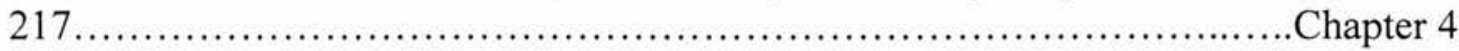

Ataollah Golpira v. The Islamic Republic of Iran, Iran-US CT, Award No. 32-211-2, 29 March, 1983. (1984) 2 Iran-US CTR 171 Chapter 4

Manuchehr Haddadi v. The United States of America, Iran-US CT, Award No 162763-3, 31 January 1985. (1987) 8 Iran-US CTR 20. .Chapter 4

Harza Engineering Company v. The Islamic Republic of Iran, Iran-US CT, Award No. 19-98-2, 30 December 1982. (1983) 1 Iran-US CTR 499. ..Chapter 4

Hood Corporation v. The Islamic Republic of Iran, Bank Markazi Iran and Bank Mellat, Iran-US CT, Award No. 142-100-3, July 13, 1984. (1986) 7 Iran-US CTR 36 Chapter 4

INA Corporation, v. The Government of the Islamic Republic of Iran, Iran-US CT, Award No. 184-161-1, 13 August, 1985. (1987) 8 Iran-US CTR 373. Chapter 4

International Systems \& Controls Corporation v. The Islamic Republic of Iran et al, Iran-US CT, Award No. 256-439-2, 26 September, 1986. (1988) 12 Iran-US CTR 239 ..Chapter 4

International Technical Products Corporation and ITP Export Corporation v. The Government of Islamic Republic of Iran et al, Iran-US CT, Award No. 196-302-3, 24 October, 1985. (1987) 9 Iran-US CTR 206. Chapter 4

ITT Industries, Inc., v. The Islamic Republic of Iran and The Organisation of Nationalised Industries of Iran, Iran-US CT, Award on Agreed Terms No. 47-156-2, 26 May, 1983. (1984) 2 Iran-US CTR 348. Chapter 4

Rouhollah Karubian v. The Government of the Islamic Republic of Iran, Iran-US CT, Award No. 569-419-2, 6 March, 1996. (1996) 8/III WTAM 177. Chapter 4

Reza Said Malek v. The Government of the Islamic Republic of Iran, Iran-US CT, Award No. 534-193-3, 11 August, 1992, (1996) 28 Iran-US CTR 246. ...Chapter 4

Mobil Oil Iran et al v. The Islamic Republic of Iran and The National Iranian Oil Company, Iran-US CT, Award No. 311-74/76/ 81/150-3, 14 July, 1987. (1988) 16 Iran-US CTR 3. 
Motorola, Inc., v. Iranian National Airlines Corporation and the Government of the Islamic Republic of Iran, Iran-US CT, Award No. 373-481-3, 28 June, 1988. (1989) 19 Iran-US CTR 73 Chapter 4

Oil Field of Texas, Inc., v. The Government of the Islamic Republic of Iran and National Iranian Oil Company, Iran-US CT, Award No. 258-43-1, 8 October, 1986. (1988) 12 Iran-US CTR 308. .Chapter 4

Thomas Earl Payne v. The Government of the Islamic Republic of Iran, Iran-US CT, Award No. 245-335-2, 8 August 1986. (1988) 12 Iran-US CTR 3. .Chapter 4

Petrolane, Inc., Eastman Whipstock Manufacturing, Inc., and Seahorse Fleet, Inc., v. the Government of the Islamic Republic of Iran et al, Iran-US CT, Award No. 518131-2, 14 August, 1991. (1992) 27 Iran-US CTR 64. ..Chapter 4

Phelps Dodge Corp. and Overseas Private Investment Corp. v. The Islamic Republic of Iran, Iran-US CT, Award No. 217-99-2, 19 March, 1986. (1987) 10 Iran-US CTR 121 Chapter 4

Phillips Petroleum Company Iran v The Islamic Republic of Iran and The National Iranian Oil Company, Iran-US CT, Award No. 425-39-2, 29 June, 1989. (1990) 21 Iran-US CTR 79. Chapter 4

Verney Rodney Pointon and Mary Lou Pointon v. The Government of the Islamic Republic of Iran, Iran-US CT, Award No. 516-322-1, 23 July, 1991. (1992) 27 IranUS CTR 49. .Chapter 4

Jack Rankin v. The Islamic Republic of Iran, Iran-US CT, Award No 326-10913-2, 3 November 1987. (1988) 17 Iran-US CTR 135. Chapter 4

Esahak Sabbonchian v. The Islamic Republic of Iran, Iran-US CT, Award No. 524313-2, 15 November, 1991. (1992) 27 Iran-US CTR 248. Chapter 4

James M. Saghi, Michael R. Saghi and Allan J. Saghi v. The Islamic Republic of Iran, Iran-US CT, Award No. 544-298-2, 22 January, 1993. (2000) 29 Iran-US CTR 20 Chapter 4

Schering Corporation v The Islamic Republic of Iran, Iran-US CT, Award No. 12238-3, 11 April 1984. (1985) 5 Iran-US CTR 361... Chapter 4

Sea-Land Service, Inc., v. The Government of the Islamic Republic of Iran and Ports and Shipping Organization, Iran-US CT, Award No 135-33-1, 22 June 1984. (1986) 6 Iran-US CTR 149. Chapter 4

SEDCO, Inc., and Sediran Drilling Company v. National Iranian Oil Company, and The Islamic Republic of Iran, Iran-US CT, First Interlocutory Award No ITL 55-1293, 28 October 1985. (1987) 9 Iran-US CTR 248 .Chapter 4 
SEDCO, Inc., v. National Iranian Oil Company, and The Islamic Republic of Iran, Iran-US CT, Interlocutory Award No 59-129-3, 27 March, 1986, (1987) 10 Iran-US CTR 180 Chapter 4

SEDCO, Inc. v National Iranian Oil Company and The Islamic Republic of Iran, IranUS CT, Award No. 309-129-3, 7 July, 1987. (1988) 15 Iran-US CTR 23 Chapter 4

Seismograph Service Corporation and Compagnie Française de Prospection Sismique v. National Iranian Oil Company and The Islamic Republic of Iran, Iran-US CT, Award No. 420-443-3, 31 March, 1989. (1990) 22 Iran-US CTR

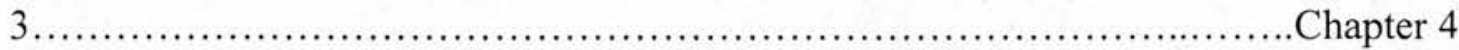

Alfred L. W. Short $v$ The Islamic Republic of Iran, Iran-US CT, Award No. 31211135-3, 14 July 1987. (1988) 16 Iran-US CTR 76. Chapter 4

Sola Tiles, Inc., v. The Government of the Islamic Republic of Iran, Iran-US CT, Award No. 298-317-1, 22 April, 1987. (1988) 14 Iran-US CTR 223...........Chapter 4

Starrett Housing Corporation, Starrett Systems, Inc., Starrett Housing International, Inc., $v$ The Government of the Islamic Republic of Iran et al, Iran-US CT, Interlocutory Award No. ITL 32-24-1, 19 December 1983. (1985) 4 Iran-US CTR 122. Chapters $4 \& 7$

Starrett Housing Corporation, Starrett Systems, Inc., Starrett Housing International, Inc., $v$ The Government of the Islamic Republic of Iran et al, Iran-US CT, Final Award No. ITL 314-24-1, 14 August, 1987. (1988) 16 Iran-US CTR 122. .Chapter 4

Emanuel Too v. Greater Modesto Insurance Associates and the United States of America, Iran-US CT, Award No. 460-880-2, 29 December, 1989. (1991) 23 Iran-US CTR 378 ..... Chapter 4

Tippets, Abbett, McCarthy, Stratton (TAMS) v. TAMS-AFFA Consulting Engineers of Iran, The Government of the Islamic Republic of Iran et al, Iran-US CT, Award No. 141-7-2, 29 June 1984. (1986) 6 Iran-US CTR 219. Chapter 4

United Painting, Inc., v. The Islamic Republic of Iran, Iran-US CT, Award No. 45811286-3, 20 December, 1989. (1991) 23 Iran-US CTR 351.............................. 4

William L. Pereira Associates v. Islamic Republic of Iran, Iran-US CT, Award No. 116-1-3, 19 March, 1984. (1985) 5 Iran-US CTR 198. Chapter 4

Kenneth P. Yeager v. The Islamic Republic of Iran, Iran-US CT, Partial Award No. 324-10199-1, 2 November, 1987. (1988) 17 Iran-US CTR 92. Chapter 4 


\section{Ad Hoc, ICSID \& UNCITRAL Arbitrations}

ADC Affiliate Limited and ADC \& ADMC Management Limited $v$. The Republic of Hungary, ICSID case No. ARB/03/16, Award, 2 October, 2006. Available online.... Chapters $5 \& 7$

ADF Group Inc. v. United States of America, ICSID case No. ARB(AF)/00/1, Award, 9 January, 2003. Available online. Chapter 7

Amco Asia Corporation et al $v$. The Republic of Indonesia, ICSID case No. ARB/81/1, Award, 21 November 1984. (1985) 24 ILM 1022..................Chapter 5

American Manufacturing \& Trading, Inc. (AMT) v. Republic of Zaire, ICSID case No. ARB/93/1, Award, 21 February, 1997. Available online. Chapter 7

Asian Agricultural Products Ltd (AAPL) v. Republic of Sri Lanka, ICSID case No. ARB/87/3, Award, 27 June, 1990. Available online. Chapter 5

Azurix Corp. v. The Argentine Republic, ICSID case No. ARB/01/12, Award, 14 July, 2006. Available online. Chapter 5

Biloune and Marine Drive Complex Ltd v. Ghana Investments Centre and the Government of Ghana, UNCITRAL arbitration, Award on Jurisdiction and Liability, 27 October 1989. (1994) 95 ILR 183. Chapter 5

CME Czech Republic B.V. v. The Czech Republic, UNCITRAL arbitration, Partial Award, 13 September 2001. Available online. Chapters $5 \& 7$

CMS Gas Transmission Company v. Republic of Argentina, ICSID case No. ARB/01/8, Award, 12 May, 2005. Available online. Chapter 7

Compañia de Aguas del Aconquija S.A. and Vivendi Universal S.A. v. Argentine Republic (Vivendi II), ICSID case No. ARB/97/3, Award, 20 August, 2007. Available online. Chapters 5 \& 7

Compañia del Desarrollo de Santa Elena S.A. v. Republic of Costa Rica, ICSID case No. ARB/96/1, Award, 17 February 2000. Available online. Chapters $1 \& 5$

Ethyl Corporation v. The Government of Canada, NAFTA, UNCITRAL arbitration, Award, 24 June 1998. Available online. Chapter 6

Enron Corporation Ponderosa Assets, L.P. v. Argentine Republic, ICSID case No. ARB/01/3, Award, 22 May, 2007. Available online. Chapter 7

Eureko B.V. v. Republic of Poland, Ad hoc arbitration, Partial Award, 19 August, 2005. Available online. Chapters 5 \& 7 
Marvin Feldman v. Mexico, NAFTA, ICSID Case No. ARB(AF)/99/1, Award, 16 December, 2002. Available online...................................... Chapter 6

GAMI Investments, Inc. v. The Government of the United Mexican States, NAFTA, UNCITRAL arbitration, Award, 15 November, 2004. Available online. Chapters $6 \& 7$

Generation Ukraine, Inc. v. Ukraine, ICSID case No. ARB/00/9, Award, 16 September 2003. Available online. Chapters $1 \& 5$

Alex Genin, Eastern Credit Limited, Inc. and A.S. Baltoil v. Republic of Estonia, ICSID case No. ARB/99/2, Award, 25 June, 2001. Available online. ... Chapter 7

Antoine Goetz et consorts c. Republique du Burundi, Affaire CIRDI ARB/95/3, Sentence, 10 February 1999. Available online. .Chapter 5

International Thunderbird Gaming Corporation v. The United Mexican States, UNCITRAL arbitration, Award, 26 January, 2006. Available online. Chapter 7

Ronald S. Lauder $v$. The Czech Republic, UNCITRAL arbitration, Award, 3 September, 2001. Available online. Chapters 5 \& 7

$L G \& E$ Energy Corp., LG\&E Capital Corp., LG\&E International Inc. V. Argentine Republic, ICSID case No. ARB/02/1, Decision on liability, 3 October, 2006. Available online. .Chapter 5

Liberian Eastern Timber Corporation (Letco) v. The Government of the Republic of Liberia, ICSID case No. ARB/83/2, Award, 31 March 1986, (1987) 26 ILM 647. Chapter 7

Ltd. Benvenuti et Bonfant srl. v. The Government of the People's Republic of the Congo, ICSID Case No. ARB/77/2, Award, 8 August 1980. (1982) 21 ILM 740 . ..Chapter 5

Loewen Group, Inc. and Raymond L. Loewen v. United States of America, ICSID case No. ARB(AF)/98/3, Award, 26 June, 2003. Available online Chapter 7

Emilio Agustin Maffezini and The Kingdom of Spain, ICSID case No. ARB/97/7, Award, 13 November 2000. Available online. Chapter 5

Metalclad Corporation v. United Mexican States, NAFTA, ICSID case No. ARB(AF)/97/1, Award, 30 August, 2000. Available online. .Chapters $6 \& 7$

Methanex Corporation v. United States of America, NAFTA, UNCITRAL arbitration, Final Award, 3 August, 2005. Available online. Chapter 6

Middle East Cement Shipping and Handling Co. v. Arab Republic of Egypt, ICSID case No. ARB/99/6, Award, 12 April 2002. Available online. .Chapters $5 \& 7$ 
Mondev International Ltd. $v$. United States of America, ICSID case No. ARB(AF)/99/2, Award, 11 October, 2002. Available online................ Chapter 7

MTD Equity Sdn. Bhd. and MTD Chile S.A. v. Republic of Chile, ICSID case No. ARB/01/7, Award, 25 May, 2004. Available online Chapter 7

Noble Ventures, Inc. v. Romania, ICSID case No. ARB/01/11, Award, 12 October, 2005. Available online Chapter 7

Occidental Exploration and Production Co. (OEPC) v. The Republic of Ecuador, UNCITRAL arbitration, Award, 1 July 2004. Available online Chapters 5 \& 7

Eudoro Armando Olguin v. Republic of Paraguay, ICSID Case No. ARB/98/5, Award, 26 July 2001. Available online. Chapter 5

Pope and Talbot. Inc. $v$. The Government of Canada, NAFTA, UNCITRAL arbitration, Interim Award, 26 June, 2000. Available online. .Chapter 6

Pope and Talbot. Inc. $v$. The Government of Canada, NAFTA, UNCITRAL arbitration, Award, 10 April, 2001. Available online Chapter 7

PSEG Global Inc. and Konya Ilgin Elektrik Üretim ve Ticaret Limited Şirketi v. Republic of Turkey, ICSID Case No. ARB/02/5, Award, 19 January, 2007. Available online. Chapter 7

Saluka Investments $B V$ v. The Czech Republic, UNCITRAL arbitration, Partial Award, 17 March, 2006. Available online. .Chapters 5 \& 7

S.D. Myers, Inc. v. The Government of Canada, NAFTA, UNCITRAL arbitration, Partial Award, 13 November, 2000. Available online. Chapters $6 \& 7$

Siemens A.G. v. The Argentine Republic, ICSID case No. ARB/02/8, Award, 6 February, 2007. Available online. Chapters 5 \& 7

Southern Pacific Properties (Middle East) Limited (SPP) v. Arab Republic of Egypt, ICSID Case No. ARB/84/3, Award, 20 May 1992. (1993) 32 ILM 933 Chapter 5

Técnicas Medioambientales TECMED S.A. v. The United Mexican States, ICSID case No. ARB (AF)/00/2, Award, 29 May, 2003. Available online Chapters 5 \& 7

Telenor Mobile Communications A.S. v. The Republic of Hungary, ICSID case No. ARB/04/15, Award, 13 September 2006. Available online Chapter 5

United Parcel of America Inc. (UPS) $v$ Government of Canada, Award on Jurisdiction, 21 November, 2002. Available online Chapter 7 
Waste Management, Inc. v. United Mexican States, ICSID case No. ARB(AF)/98/2, Award, 2 June 2000. Available online. Chapters $1 \& 7$

Wena Hotels Ltd. v. Arab Republic of Egypt, ICSID case No. ARB/98/4, Award, 8 December 2000. (2002) 41 ILM 896 Chapters $5 \& 7$

\section{Other International Tribunals}

American Independent Oil Co. (Aminoil) v. Kuwait, Reuter, Sultan, and Fitzmaurice, arbitrators, Award, 24 March 1982. (1982) 21 ILM 976. Chapters 4 \& 6

British Petroleum Exploration Co. v. Libyan Arab Republic, Lagergren, sole arbitrator, Award, 10 October, 1973. (1973) 53 ILR 297 Chapter 7

Liselotte Hauer $v$ Land RheinlandPfalz, ECJ, Case 44/79, Judgment 13 December, 1979. Available online .Chapter 3

George W. Hopkins (US v. Mexico), US-Mexican General Claims Commission, Opinion and decision, 31 March, 1926, (1926) 21 AJIL

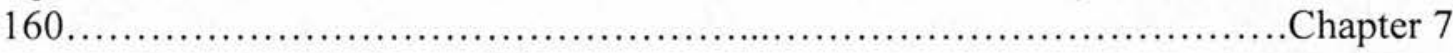

Isle of Palmas (The Netherlands v. US), Huber, sole arbitrator, Award, 4 April, 1928, (1928) 2 RIAA 829 Chapter 7

$J$ Nold, Kohlen-und Baustoffgroßhandlung $v$ Commission of the European Communities, ECJ, Case 4-73, Judgment, 14 May, 1974. Available

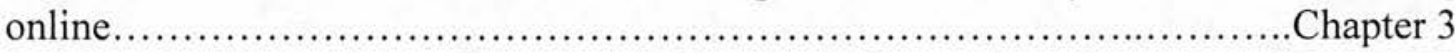

Lena Goldfields, Ltd. v. Union of Soviet Socialist Republics, Stutzer and Scott arbitrators, Award, 3 September 1930, reprinted in A Nussbaum, 'The Arbitration Between the Lena Goldfield's, Ltd. and the Soviet Government', (1950) Cornell LQ 31. .Chapter 4

Libyan American Oil Co. v. Libyan Arab Republic, Mahmassani, sole arbitrator, Award, 12 April 1977. (1981) 20 ILM 1................................Chapter 6

Neer claim (US v. Mexico), US-Mexican General Claims Commission, Opinion, 15 October, 1926. (1926) 4 RIAA 60, or (1927) AJIL 555.................................... 2

North American Dredging Company of Texas (US v. Mexico), US-Mexican General Claims Commission, Decision. (1926) 4 RIAA 26.......................Chapters $2 \& 6$

Norwegian Shipowners (Norway v. US), Anderson, Vogt, and Valloton, arbitrators, Award, 13 October, 1922. (1922) 1 RIAA 307. Chapters 4 \& 7

Sapphire International Petroleum Ltd. v. National Iranian Oil Company, Cavin, sole arbitrator, Award, 15 March 1963. (1967) 35 ILR 136. Chapter 4 
Texas Overseas Petroleum Co. \& California Asiatic Oil Co. (Topco/Calasiatic) v Libyan Arab Republic, Dupy, sole arbitrator, Award, 19 January 1977. (1978) 17 ILM 1 .

Chapters $2 \& 7$

\section{Domestic Courts}

Concrete Pipe and Products of California, Inc. v. Construction Laborers Pension Trust for Southern California, (1993) 508 US 602 .........................Chapter 6

Filartiga v. Peña-Irala, US Circuit Court of Appeals, $2^{\text {nd }}$ Circuit, 30 June, 1980. Available online. Chapter 3

Lochner v. People of the State of New York, (1905) 198 US 45...............Chapter 6 Lucas v. South Carolina Coastal Council, (1992) 505 US 1003................Chapter 6 Penn Central Transportation Co. v. New York City, (1978) 438 US

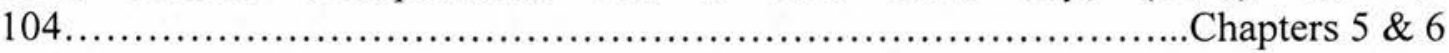

Pennsylvania Coal Co. v. Mahon, (1922) 260 US 393....................................... 6 


\section{List of Treaties and Other International Instruments}

\section{Treaties}

1778

Treaty of Amity and Commerce between France and the US. Available online Chapter 5

Treaty of Amity and Commerce between Prussia and the US. Available online Chapter 5

General treaty of Peace, Amity, Navigation and Commerce between New

Granada and the US. Available online Chapter 5

Treaty of Peace, Friendship, Commerce, and Navigation between Bolivia and the US. Available online Chapter 5

Treaty of Friendship, Commerce, and Navigation between Paraguay and the US. Available online. Chapter 5

General Treaty of Amity, Commerce, and Consular Privileges between El Salvador and the US. Available online. Chapter 5

Treaty of Friendship, Commerce and Navigation between Colombia and Italy. Available online. Chapter 2

Treaty of Friendship, Commerce, and Consular Rights between Austria and the US. Available online. .Chapter 5

Montevideo Convention on the Rights and Duties of States. Available online. Chapter 2 
American Treaty of Pacific Settlement (Pact of Bogotá). Available online Chapter 2

Convenio Económico de Bogotá (Economic Agreement of Bogotá). Available online. Chapter 7

Universal Declaration of Human Rights. Available online Chapter 3

Convention for the Protection of Human Rights and Fundamental Freedoms (European Convention on Human Rights). Available online..... Chapter 3

Treaty of Amity, Economic Relations, and Consular Rights between Iran and the US. Available online. Chapter 5

Treaty for the Promotion and Protection of Investments between Pakistan and Germany. Available online. Chapters $2 \& 5$

Traité entre la Suisse et la Tunisie relatif à la Protection et à l'Encouragement des Investissements de Capitaux (Switzerland-Tunisia BIT). Available online Chapter 5

Convention on the Settlement of Investment Disputes between States and Nationals of Other States (Washington Convention). Available online Chapters $2 \& 5$

International Covenant on Civil and Political Rights. Available online. .Chapter 3

International Covenant on Economic, Social, and Cultural Rights. Available online. Chapters $2 \& 3$

Treaty between Germany and Uganda concerning the Encouragement and Reciprocal Protection of Investments. Available online. ... Chapter 5 
Treaty of Amity and Economic Relations between Thailand and the US Chapter 5

Treaty of Amity and Economic Relations between Togo and the US. Chapter 5

Agreement concerning the Encouragement and Reciprocal Protection of Investments between Denmark and Indonesia. Available online........Chapter 5

American Convention on Human Rights (Pact of San José de Costa Rica). Available online. Chapter 3

Vienna Convention on the Law of Treaties. Available online Chapter 7

Agreement on Economic Co-operation between The Netherlands and Malaysia. Available online. Chapter 5

Convention entre la Suisse et l'Égypte concernant l'Encouragement et la Protection Réciproque des Investissements (Egypt-Switzerland BIT). Available online. Chapter 5

Agreement between the UK and Singapore for the Promotion and Protection of Investments. Available online Chapters $2 \& 5$

Agreement between the UK and Indonesia for the Promotion and Protection of Investments. Available online. Chapter 5

Treaty concerning the Promotion and Reciprocal Protection of Capital Investment between Benin and Germany. Available online. .Chapter 5

Vienna Convention on State Succession in Respect of Treaties. Available online. Chapter 2 
Agreement between the UK and the Philippines for the Promotion and Protection of Investments. Available online. Chapter 2

1981

African Charter on Human and Peoples' Rights. Available online.... Chapter 3

Declaration of Algeria concerning the Settlement of Claims by the US and Iran. (1983) 1 Iran-US CTR 9, or (1981) 20 ILM 231 Chapter 4

Treaty between Somalia and Germany concerning the Encouragement and Reciprocal Protection of Investments. Available online Chapter 5

Agreement between Cameroon and the UK for the Promotion and Protection of Investments. Available online. Chapter 5

Agreement between Belgium/Luxemburg and Sri Lanka for the Promotion and Protection of Investments. Available online. Chapter 5

Treaty between Egypt and the US concerning the Reciprocal Promotion and Protection of Investments. Chapter 5

Agreement for the Promotion and Protection of Investments between Sweden and Yemen. Available online. Chapter 7

Convention Establishing the Multilateral Investment Guarantee Agency. Available online. Chapters $6 \& 7$

Agreement between The Netherlands and Oman on the Encouragement and Reciprocal Protection of Investments. Available online. Chapter 5

Agreement between Malta and Belgium-Luxemburg concerning the Reciprocal Encouragement and Protection of Investments. Available online. Chapter 5

ASEAN Agreement for the Promotion and Protection of Investments. Available online. Chapters $6 \& 7$ 
Accordo tra Italia e Malaysia sulla Reciproca Promozione e Protezione degli Investimenti (Italy-Malaysia BIT). Available online. Chapter 5

Free Trade Agreement between Canada and the US. (1988) 27 ILM 281 Chapter 6

Accord entre la France et la Bulgarie sur l'Encouragement et la Protection Réciproque des Investissements (Algeria-Bulgaria BIT). Available online. Chapter 5

Accord entre la France et le Nigeria sur l'Encouragement et la Protection Réciproques des Investissements (France-Nigeria BIT). Available online. Chapter 5

Accordo per la Promozione e la reciproca Protezione degli Investimenti fra Argentina e Italia (Argentina-Italy BIT). Available online. Chapter 2

Agreement between Australia and Vietnam on the Reciprocal Promotion and Protection of Investments. Available online Chapter 5

Agreement between Denmark and Poland for the Promotion and the Reciprocal Protection of Investments. Available online. . . Chapter 5

Agreement between Hungary and Norway for the Promotion and Reciprocal Protection of Investments. Available online Chapter 5

Agreement between the Czech and the Slovak Republic and China for the Promotion and the Reciprocal Protection of Investments. Available online Chapter 5

Agreement on Encouragement and Reciprocal Protection of Investments between the Netherlands and Argentina. Available online. Chapter 7

North American Free Trade Agreement (NAFTA). Available online Chapters 2, 6 \& 7 
Accord entre la France et l'Algerie sur l'Encouragement et la Protection Réciproque des Investissements (Algeria-France BIT). Available online. Chapters $2 \& 5$

Agreement between Finland and Korea for the Promotion and Protection of Investments. Available online. Chapter 5

Agreement between the UK and Ukraine for the Promotion and Reciprocal Protection of Investments. Available online Chapter 5

Accordo tra Italia e Lituania sulla Promozione e Protezione degli Investimenti (Italy-Lithuania BIT). Available online. Chapter 5

Agreement between Estonia and Israel for the Promotion and Reciprocal Protection of Investments. Available online. Chapter 5

Agreement on Encouragement and Reciprocal Protection of Investments between Lithuania and The Netherlands. Available online. Chapter 5

Protocolo de Promoción y Protección Recíproca de Inversiones Provenientes de Estados No Partes del Mercosur (Buenos-Aires Protocol of Mercosur). Available online Chapters $2 \& 7$

Protocolo de Colonia para la Promoción y Protección Recíproca de Inversiones en el Mercosur (Colonia Protocol of Mercosur).Available online Chapters $2 \& 7$

Energy Charter Treaty (ECT). Available online Chapters $2,6 \& 7$

Acuerdo entre Chile y Paraguay para la Promoción y Protección Recíproca de las Inversiones (Chile-Paraguay BIT). Available online Chapter 7

Agreement between Denmark and Mongolia concerning the Promotion and Reciprocal Protection of Investments. Available online Chapter 5

Agreement between Sweden and Albania of the Promotion and Reciprocal Protection of Investments. Available online. Chapter 5

Convenio entre Noruega y Perú sobre la Promoción y Protección Recíproca de Inversiones (Norway-Perú BIT). Available online Chapter 5 
Accord entre Belgique-Luxembourg et la Côte d'Ivoire concernant la Promotion et la Protection Réciproques des Investissements. (Belgium and Luxembourg-Côte d'Ivoire BIT). Available online......................Chapter 7

Accord entre la France et le Libano sur l'Encouragement et la Protection Reciproques des Investissements (France-Lebanon BIT). Available online Chapter 7

Convenio entre Chile y Ecuador para la Promoción y Protección Recíprocas de Inversiones (Chile-Ecuador BIT). Available online Chapter 5

Acordo entre o Brasil e o Cuba para a Promoção e Proteção Recíproca de Investimentos (Brazil-Cuba BIT). Available online .Chapter 5

Acuerdo entre Costa Rica y Argentina para la Promoción y Protección Recíproca de las Inversiones (Argentina-Costa Rica BIT). Available online Chapter 2

Agreement on Reciprocal Promotion and Protection of Investments between Iran and South Africa. Available online. ..Chapter 7

Agreement between Canada and Armenia for the Promotion and Protection of Investments. Available online .Chapter 2

Agreement between the Czech Republic and Ireland for the Promotion and Reciprocal Protection of Investments. Available online.... Chapter 5

Treaty between the US and Jordan concerning the Encouragement and Reciprocal Protection of Investment. Available online. Chapter 5

Agreement between Australia and Lithuania on the Promotion and Protection of Investments. Available online .Chapter 5

Agreement between China and Swaziland on the Promotion and Reciprocal Protection of Investments. Available online Chapter 5

Agreement between Japan and Russia on the Encouragement and Protection of Capital Investments. Available online Chapter 5 
Agreement between Albania and Finland on the Promotion and Protection of Investments. Available online Chapter 5

2000

Acuerdo entre Chile y Colombia para la Promoción y Protección Recíproca de Inversiones (Chile-Colombia BIT). Available online Chapter 5

Agreement between Mexico and Austria on the Promotion and Protection of Investments. Available online Chapter 2

Agreement between Portugal and Turkey on the Reciprocal Promotion and Protection of Investments. Available online. Chapter 7

Acuerdo entre Guatemala y España para la Promoción y Protección Recíproca de Inversiones (Guatemala-Spain BIT). Available online Chapter 7

Agreement between Bahrain and Thailand for the Promotion and Protection of Investments. Available online Chapter 5

Agreement between Bosnia and Herzegovina and the UK for the Promotion and Protection of Investments. Available online. Chapter 7

Convenio entre Chile e Islandia para la Promoción y Protección Recíproca de las Inversiones (Chile-Islandia BIT). Available online .Chapter 2

Chile-US Free Trade Agreement. Available online. Chapters $2 \& 6$

Singapore-US Free Trade Agreement. Available online Chapters $6 \& 7$

Tratado de Libre Comercio entre Mexico y Uruguay (Mexico-Uruguay FTA). Available online. Chapter 6

Australia-US Free Trade Agreement. Available online. Chapter 6

Agreement between Iceland and Lebanon for the Promotion and Reciprocal Protection of Investments. Chapter 5 
Central America-Dominican Republic-US Free Trade Agreement (CAFTADR). Available online. Chapter 6

Morocco-US Free Trade Agreement. Available online...............Chapter 6

Tratado de Libre Comercio entre Chile y Corea del Sur (Chile-South Korea FTA). Available online. Chapter 6

Treaty between the US and Uruguay Concerning the Encouragement and Reciprocal Protection of Investments. Available online.... Chapters 1, 2, 5 \& 7

Agreement between Canada and Perú for the Promotion and Protection of Investments. Available online. Chapters $1,5 \& 7$

Agreement between Japan and Malaysia for an Economic Partnership. Available online. Chapter 6

Oman-US Free Trade Agreement. Available online Chapters $6 \& 7$

Panama-Singapore Free Trade Agreement. Available online. Chapter 6

\section{UN General Assembly Resolutions}

UNGA Res. 217 (III), 10 December. Available online. Chapter 3

UNGA Res. 523 (VI), 12 January. Available online Chapter 2

UNGA Res. 626 (VII), 21 December. Available online Chapter 2 1954

UNGA Res. 837 (IX), 14 December. Available online Chapter 2 1958

UNGA Res. 1314 (XIII), 12 December.Available online .Chapter 2 1960

UNGA Res. 1515 (XV), 15 December. Available online. Chapter 2 
UNGA Res. 1803 (XVII), 14 December. Available online Chapter 2 1966

UNGA Res. 2158 (XXI), 25 November. Available online Chapter 2

UNGA Res. 2200A (XXI) 16 December. Available online Chapter 2 1968

UNGA Res. 2386 (XXIII), 19 November. Available online Chapter 2 1970

UNGA Res. 2625 (XXV), 24 October. Available online Chapter 2 UNGA Res. 2692 (XXV), 11 December. Available online Chapter 2 1972

UNGA Res. 3016 (XXVII), 18 December. Available online Chapter 2 1973

UNGA Res. 3171 (XXVIII), 17 December. Available online Chapter 2 1974

UNGA Res. 3201 (S-VI), 1 May. Available online Chapter 2

UNGA Res. 3202 (S-VI), 1 May. Available online Chapter 2

UNGA Res. 3281 (XXIX), 12 December. Available online Chapter 2 1986

UNGA Res. 41/132, 4 December. Available online Chapter 3

\section{Other}

American Declaration of the Rights and Duties of Man. Available online. Chapter 3 
Charter for an International Trade Organization (Havana Charter). Available online Chapters $6 \& 7$

ICC International Code of Fair Treatment for Foreign Investments...Chapter 6 1955

GATT Resolution on International Investment for Economic Development......................................................... 5

Draft Convention on Investments Abroad (Abs/Shawcross Draft). Available online. Chapters $6 \& 7$

Draft Convention on the International Responsibility of States for Injuries to Aliens (Harvard Draft). (1961) 55 AJIL 545. .Chapter 6

OECD Draft Convention on the Protection of Foreign Property. (1968) 7 ILM 117. Chapters $5,6 \& 7$

UNCITRAL Arbitration Rules. Available online Chapter 7

Third Restatement of the Foreign Relations Law of the United States. American Law Institute, Restatement of the Law Third. The Foreign Relations Law of the United States (1987). Chapters $6 \& 7$ 1990

UN Draft Code of Conduct on Transnational Corporations. Available online. Chapters $6 \& 7$

World Bank Guidelines on the Treatment of Foreign Direct Investment. Available online Chapters $5,6 \& 7$ 
Annual Report of the I/A Commission HR. Available online ..Chapter 3

1998

Multilateral Agreement on Investment (MAI), Draft Consolidated Text. Available online. Chapters 6 \& 7

2001

ILC Articles on Responsibility of States for Internationally Wrongful Acts.

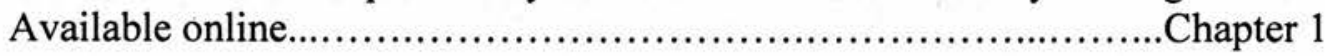
2006

Report of the ILC, Fifty-eighth Session (1 May - 9 June and 3 July - 11 August 2006). Available online. Chapter 2 


\section{INTRODUCTION}

That aliens should be protected is an old principle of the law of nations. Known to the Romans since Cicero's time, it was only developed in the $19^{\text {th }}$ century as a consequence of the evolution of world economy. ${ }^{1}$ This protective principle offers a minimum standard of treatment to foreigners. It provides essentially for two things: security of the person from injury or restraint, and the preservation of property from political risk in the host-state. ${ }^{2}$ That is to say, the protection of property from potential interferences based on ideological hostility towards foreign investment, nationalism, and changes in industry patterns and domestic state policy considerations. These interferences have generally adopted the form of the taking of foreign property, whether as an outright deprivation or a major infringement with it. ${ }^{3}$ The articulation of a branch of international law aimed at reducing political risk is a relatively recent development. Known as international investment law, it comprises today an older branch of the law of nations -the international law of expropriation. The latter is founded on three distinct, but closely related concepts: property, taking and compensation. ${ }^{4}$

\footnotetext{
' See F Dunn, 'International Law and Private Property Rights', (1928) 28 Colum. LR 166, at 171-3; and J Herz, 'Expropriation of Foreign Property', (1941) 35 AJIL 243, at 244.

${ }^{2}$ Dunn, supra note 1, at 176.

${ }^{3}$ See P Comeaux and N Kinsella, Protecting Foreign Direct Investment under International Law. Legal Aspects of Political Risk (1996), xvii; and M Sornarajah, The International Law on Foreign Investment (2004), 75-87.

${ }^{4}$ See R Dolzer, 'Indirect Expropriation of Alien Property', (1986) 1/I ICSID Rev. 41, at 41.
} 
Higgins observes that the right to hold property reflects a social instinct. As a consequence, it has a very long history. ${ }^{5}$ It is not uncommon to find a reference to property in the sources of international law. A definition, however, is hardly ever seen. ${ }^{6}$ According to Katzarov, a certain consensus among lawyers and scholars has evolved over its content, comprising a positive and negative aspect. ${ }^{7}$ On its positive side, property is an absolute right of disposal. In practice, it is only generally unlimited. On its negative side, it is an exclusive right, conferring upon its holder the power to forbid any other to perform an act of disposal. This notion of property is not restricted to tangibles. Rights have been accepted as an integral part of the concept of property in international law by tribunals and scholars. ${ }^{8}$ Not only the right to hold property, but also its social function have been commonly recognised by conservative and liberal authors, including Marxist ones. This notion, which can be traced back to medieval times, is found today in virtually all nations. ${ }^{9}$ There is an inherent tension in the co-existence of private property and its social function, as the requirements of society sometimes come into conflict with individual property rights.

\footnotetext{
5 R Higgins, 'The Taking of Property by the State: Recent Developments in International Law', (1982) 176/III RdC 259, at 273.

${ }^{6}$ See ibid., 269.

${ }^{7}$ See K Katzarov, The Theory of Nationalisation (1964), as referred to in Higgins, supra note 5, at 270.

${ }^{8}$ On the broad notion of property in the international law of expropriation, see, e.g., Herz, supra note 1, at 244-5; Higgins, supra note 5, at 271; M Pellonpää and M Fitzmaurice, 'Taking of Property in the Practice of the Iran- United States Claims Tribunal', (1988) 19 Neth. YIL 53, at 58; Comeaux and Kinsella, supra note 3, at 1-2; G Sacerdoti, 'Bilateral Treaties and Multilateral Instruments on Investment Protection', (1997) $269 R d C$ 251, at 381; H Sedigh, 'What Level of Host State Interference Amounts to a Taking under Contemporary International Law', (2001) 2/II JWIT 631, at 647; T Waelde and A Kolo, 'Environmental Regulation, Investment Protection and 'Regulatory Taking' in International Law', (2001) 50/IV ICLQ 811, at 835; Y Dinstein, 'Deprivation of Property of Foreigners under International Law', in N Ando et al (eds.), Liber Amicorum Judge Shigeru Oda (2002), 856; G Sampliner, 'Arbitration of Expropriation Cases under U.S. Investment Treaties - A Threat to Democracy or the Dog That Didn't Bark?', (2003) 18/I ICSID Rev. 1, at 14; Y Fortier and S Drymer, 'Indirect Expropriation in the Law of International Investment: I Know It When I See It, or Caveat Investor', (2004) 19/II ICSID Rev. 293, note 9 at 296; and J Paulsson and Z Douglas, 'Indirect Expropriation in Investment Treaty Arbitrations', in N Horn (ed), Arbitrating Foreign Investment Disputes. Procedural and Substantive Legal Aspects (2004), 152-3.

${ }^{9}$ See Higgins, supra note 5, at 274-5.

See, also, F Mann, 'Outlines of a History of Expropriation', (1959) 75 LQR 188, at 189.
} 
And this tension between personal and community interests is at the core of the notion of takings.

Expropriation was, and still is, the main interference risked by an alien investing abroad. There is no unanimously agreed-upon definition of it, however. The term is generally equated to the taking of property by the state. ${ }^{10}$ In other words, its actual or effective deprivation, either by ousting the owner and claiming the title, or by destroying the property or severely impairing its utility. ${ }^{11}$ Exceptionally, taking and expropriation have been distinguished in international case-law. In the ELSI case, for instance, the International Court of Justice (ICJ) had to interpret the terms taking and espropriati, used in the English and Italian versions -respectively- of a friendship, commerce and navigation treaty $(\mathrm{FCN})$ concluded between the US and Italy. In that opportunity, the ICJ considered the former to be "wider and looser" than the latter. ${ }^{12}$ Some authors have also perceived taking and expropriation to be different. For example, Paulsson and Douglas distinguish them on their effects. While a taking is non-compensable, they argue, an expropriation requires compensation. $^{13}$

Expropriations have received other names too. In the 1970 s, Weston called them -rather unsuccessfully- wealth deprivations, in an attempt to introduce a

\footnotetext{
${ }^{10}$ See, e.g., Pellonpää and Fitzmaurice, supra note 8, at 55; A Mouri, The International Law of Expropriation as Reflected in the Work of the Iran-U.S. Claims Tribunal (1994), 66; A Avanessian, Iran-United States Claims Tribunal in Action (1993), 29; Comeaux and Kinsella, supra note 3, at 3; R Jennings and A Watts, Oppenheim's International Law (1996), note 9 at 916; F. Beveridge, The Treatment and Taxation of Foreign Investment under International Law (2000), at 13; C Brower and J Brueschke, The Iran-United States Claims Tribunal (1998), note 1718 at 369; J Dugard, International Law. A South African Perspective (2000), 225; and D Wallace, 'Case Study under NAFTA: Lessons for the Wise?', in N Horn (ed), Arbitrating Foreign Investment Disputes. Procedural and Substantive Legal Aspects (2004), 255.

${ }^{11}$ See B Garner (ed), Black's Law Dictionary (1999), 453 \& 1467.

${ }^{12}$ Elettronica Sicula, S.p.A. (ELSI) (US v. Italy), International Court of Justice, Judgment, 20 July 1989, (1989) 28 ILM 1138, para. 113.

${ }^{13}$ See Paulsson and Douglas, supra note 8 , at 148-50.
} 
"normatively neutral statement" that would replace wealth for "the more popular 'property'", ${ }^{14}$ The other notions of expropriation normally used in doctrine, and sometimes in treaties and judicial decisions, refer to specific forms of takings. Nationalisations are the expropriation of one or more major industries or resources within a general programme of social and economic reform. ${ }^{15}$ Dolzer and Stevens call the transfer of property, to nationals of the host state, indigenisation. ${ }^{16}$ Requisition refers to the power of an occupant state to use the resources of the occupied territory and the services of the persons subject to the occupation regime for the maintenance of its military forces, in return for compensation. ${ }^{17}$ Takings or expropriation, however, should not be confused with sequestration, defined in comparative law as the action ordered by national authorities under its domestic law, by which the state assumes temporary control over an object of private property belonging to someone subject to its jurisdiction, without transfer of title and without the payment of compensation. ${ }^{18}$ An example of this form of measure is the seizure of property as a result of a sanction imposed by the state in the exercise of its policepowers. In all, there is an extensive literature on the terminology and classification of expropriations, a topic that remains not fully clear, consistent or established because it originates in domestic law and practice, and is not easily translated to the international level. $^{19}$

International law traditionally recognises the state's right to expropriate foreign property, under certain conditions. The state measure resulting in a deprivation will

\footnotetext{
${ }^{14}$ See B Weston, 'CConstructive Takings' under International Law: A Modest Foray into the Problem of 'Creeping Expropriation', (1975) 16/I Virginia LR 103, at 112-3.

${ }^{15}$ See I Brownlie, Principles of Public International Law (2003), 512-5.

${ }^{16}$ R Dolzer and M Stevens Bilateral Investment Treaties (1995), 98.

${ }^{17} \mathrm{R}$ Dolzer, 'Requisitions', in R Bernhardt (ed.), EPIL (2000), Vol. IV, at 205.

${ }^{18} \mathrm{R}$ Dolzer, 'Sequestration', in R Bernhardt (ed.), EPIL (2000), Vol. IV, at 383.

${ }^{19}$ UNCTAD, International Investment Agreements: Key Issues (2004), Vol. I, at 236.
} 
be considered lawful under international norms if it is for a public purpose, of a nondiscriminatory nature and followed by the payment of compensation. More recently, treaty and international case-law have added a fourth requirement: due process of law in the execution of the respective measure. ${ }^{20}$ If the national authorities fail to comply with any of these requirements, the taking would constitute a confiscation. ${ }^{21}$ The state would incur in international responsibility and would be liable for breaching the minimum standard governing the treatment of aliens. These norms only come into play where the property of foreigners is involved. In other words, international law does not generally provide a remedy to domestic claimants for the expropriation of their property by their own authorities. ${ }^{22}$ These apparently simple rules have lacked, however, clarity not only at the moment of establishing the time, form and amount of compensation that should be paid in case of a lawful or even an unlawful expropriation, but also at the moment of determining whether compensation is due at all.

According to the 2001 Articles on State Responsibility of the International Law Commission (ILC), a wrongful act entails two obligations for the responsible state under general international law: cessation and reparation. ${ }^{23}$ The latter was expressly recognised in 1928 by the Permanent Court of International Justice (PCIJ), in an often quoted passage of the Chorzow Factory case:

The essential principle contained in the actual notion of an illegal act -a principle which seems to be established by international practice and in particular by the decisions of arbitral tribunals- is that reparation must, so far as possible, wipe out all the consequences of the illegal act and re-establish the situation which would, in all

${ }^{20}$ See Chapter 5 infra.

${ }^{21}$ Brownlie, supra note 15 , at 509.

${ }^{22}$ Comeaux and Kinsella, supra note 3, at 5.

See Chapters 3 and 5 infra.

${ }^{23}$ See Arts. 30 and 31 of the Articles on Responsibility of States for Internationally Wrongful Acts, adopted by the International Law Commission in 2001. Available at $<$ http://www.un.org/law/ilc $>$ (last visited $31 \mathrm{March}, 2008)$. 
probability, have existed if that act had not been committed. Restitution in kind, or, if this is not possible, payment of a sum corresponding to the value which a restitution in kind would bear; the award if need be, of damages for loss sustained which would not be covered by restitution in kind or payment in place of it -such are the principles which should serve to determine the amount of compensation due for an act contrary to international law. ${ }^{24}$

In conformity with Article 34 of the ILC Articles, full reparation for the injury caused by an internationally wrongful act shall take the form of restitution, compensation and satisfaction, either singly or in combination. ${ }^{25}$ Restitution is the reestablishment of the situation which existed before the wrongful act was committed, when it is materially possible and the burden derived from it is proportional to the benefit to be obtained. ${ }^{26}$ It might involve the restitution of physical assets or sums of money. It might also involve the payment of a replacement value for a damaged asset, or the payment of the costs for its repair, as long as the asset is replaceable and marketable in a used condition. ${ }^{27}$ Restitution should normally prevail over compensation in international law. ${ }^{28}$ This means that the obligation to compensate will come into play only when the injury is not made good by restitution, covering any financially assessable damage, including loss of profits. ${ }^{29}$ In many cases it is simply not possible to restore the situation that existed before the commission of the wrongful act. For this reason, states and other subjects of international law

\footnotetext{
${ }^{24}$ See Factory at Chorzow (Germany v Poland), PCIJ, Judgment, 13 September 1928, (1928) PCIJ Rep. Series A No 17, at 47.

See, also, J Crawford, The International Law Commission's Articles on State Responsibility. Introduction, Text and Commentaries (2005), 211.

${ }^{25}$ See Art. 34 of the ILC Articles.

${ }^{26}$ See Art. 35 of the ILC Articles.

${ }^{27}$ I Marboe, 'Compensation and Damages in International Law. The Limits of the 'Fair Market Value", (2006) 7/V JWIT 723, at 744-5.

${ }^{28}$ The primacy of restitution can be traced back to the Chorzow Factory case. Arts. 35 and 36 of the ILC Articles refer to it too.

See Crawford, supra note 24, at 213-4, and Marboe, supra note 27, at 744.

${ }^{29}$ See Art. 36 of the ILC Articles.
} 
commonly seek compensation, which will normally consist of a monetary payment. ${ }^{30}$ Its determination is, therefore, an essential aspect of international law.

Compensation is also one of the requirements of a lawful taking. In doctrine, this term is distinguished from damages, which refers to the consequence of a breach of an international obligation. No such obligation is violated when a state lawfully expropriates foreign property. ${ }^{31}$ The ILC made no distinction between the two notions in its Articles, largely because it relied on the case-law of the PCIJ and the ICJ, and neither of these tribunals distinguishes them carefully in their judicial decisions. ${ }^{32}$ The issue is further confounded by the fact that international case-law recognises the same financial effect for both lawful and unlawful expropriations, in general. This situation has been exceptionally -and properly- criticised by tribunals, judges and authors. ${ }^{33}$ The practical difference between the two types of takings is usually found elsewhere; in the obligation of restitution, which would only originate from the commission of a wrongful act -i.e. of an unlawful expropriation. However, as Marboe points out:

Claimants in their written and oral submissions sometimes rely on the standard of compensation for a lawful expropriation, even if they are of the opinion that the expropriation was unlawful. This can be explained by the fact that restitution is often not regarded as the best or the most desirable remedy. Claimants and tribunals thus frequently turn immediately to the secondary remedy, the 'compensation'. Furthermore, the choice of this standard perhaps is considered to be helpful for the acceptability of their claim by the court or tribunal and by the respondent State because it does not 'punish' the State for having acted illegally. ${ }^{34}$

\footnotetext{
${ }^{30}$ See Crawford, supra note 24, at 218-9.

${ }^{31}$ Marboe, supra note 27, at 725-6.

${ }^{32} \mathrm{Ibid}$., note 3 at 724 \& note 14 at 726 .

${ }^{33}$ See ibid., 726-8.
}

See, also, D Bowett, 'State Contracts with Aliens: Contemporary Developments on Compensation for Termination or Breach', (1988) 59 BYIL 49, at 61; and G Sacerdoti, 'The Admission and Treatment of Foreign Investment under Recent Bilateral and Regional Treaties', (2000) 1/I JWIT 105, at 123.

${ }^{34}$ Marboe, supra note 27, at 728. 
The problem of compensation was highly debated by capital-importing and capital-exporting states after the emergence of the notion of nationalisation in the first half of the $20^{\text {th }}$ century. Particularly, the question of the amount of compensation required for an expropriation to be considered lawful ${ }^{35}$. This issue has been largely settled by treaty practice in the last decades. ${ }^{36}$ Ironically, the same changes in international economy and politics that brought the clarification of the problem of compensation have highlighted a long-present and, until not so long, dormant issue in the international law of expropriation: that of indirect takings.

Expropriations may occur as an outright taking or as measures having an equivalent effect. Normally referred to as direct expropriation, the former may come as a nationalisation or an expropriation, depending on whether the actual taking is of a general kind or is property or enterprise specific. ${ }^{37}$ Historically, outright takings were the first and most common form of expropriation, but are nowadays rare. ${ }^{38}$ Only occasionally, modern investment treaty cases relate to direct takings. ${ }^{39}$ It is generally easy to establish when a direct expropriation has occurred, for they are normally adopted through legislative or administrative measures. If it did occur, compensation is due, no matter what the cause of the taking was. ${ }^{40}$ Indirect expropriation refers to those measures that falling short of a direct taking, amount in their effects to one, thus requiring compensation. This type of taking, the prevalent

\footnotetext{
${ }^{35}$ U Kriebaum, 'Regulatory Takings: Balancing the Interests of the Investor and the State', (2007) 8/V JWIT 717 , at 717 .

${ }^{36}$ See Chapter 2 infra.

${ }^{37}$ UNCTAD, supra note 19 , at 235.

Both involve the physical taking of property.

Ibid., at 236.

${ }^{38}$ See UNCTAD, supra note 19, at $236 \& 240$.

${ }^{39}$ See, e.g., Compañia del Desarrollo de Santa Elena S.A. v. Republic of Costa Rica, ICSID case No. ARB/96/1, Award, 17 February 2000, available at <http://www.worldbank.org/icsid/cases > (last visited 31 March, 2008).

${ }^{40}$ Kriebaum, supra note 35 , at 717.
} 
form today, has received many different names and definitions in international law.

The terms de facto, disguised, creeping, consequential, or constructive expropriation, as well as regulatory takings, stress certain aspects of indirect expropriations in their definitions. The development of these notions has been progressive, which explains why some of them relate to behaviour that would not have provided a sound legal basis for an expropriation claim under a $\mathrm{FCN}$, but would do so under a bilateral investment treaty (BIT). ${ }^{41}$

Contrary to a de jure or formal taking, a de facto or informal one involves no express legislative or administrative measure announcing the expropriation. However, the benefit of the property for the owner is effectively neutralised by the correspondent governmental act. ${ }^{42}$ The name disguised expropriation indicates that it is not visibly recognisable as a taking. ${ }^{43}$ The notion of creeping expropriation emphasises the slow and incremental encroachment of the property rights of the alien by a group of measures that only retrospectively will become evident as a taking. ${ }^{44}$ Creeping expropriations are comprised of a number of elements, none of which can separately constitute the international wrong. ${ }^{45}$ Modern investment treaty case-law has defined them as:

\footnotetext{
${ }^{41}$ M Reisman and R Sloane, 'Indirect Expropriation and its Valuation in the BIT Generation', (2003) 74 BYIL 115, at 119.

See Chapter 5 infra.

${ }^{42}$ See, e.g., Mouri, supra note 10 , at 70.

${ }^{43}$ Sornarajah, supra note 3 , at 350.

See Barcelona Traction (Belgium v. Spain), ICJ, Judgment, 5 February 1970, Dissenting Opinion of Judge Fitzmaurice, (1971) 3 ICJ Rep.

${ }^{44}$ Reisman and Sloane, supra note 41, at 124; and Sornarajah, supra note 3, at 350.

${ }^{45}$ Waste Management, Inc. v. United Mexican States, ICSID case No. ARB(AF)/98/2, Award, 2 June 2000, Dissenting Opinion of Keith Highet, at para. 17, available at $<$ http://ita.law.uvic.ca/documents/WasteMgmt-Jurisdiction-dissent.pdf> (last visited 31 March, 2008).
} 
a form of indirect expropriation with a distinctive temporal quality in the sense that it encapsulates the situation whereby a series of acts attributable to the State over a period of time culminate in the expropriatory taking of such property. ${ }^{46}$

Consequential expropriations refer, according to Reisman and Sloane, to the failure of the host state to create, maintain, and properly manage the legal, administrative, and regulatory normative framework established in an investment treaty. ${ }^{47}$ A constructive expropriation points out to the fact that effects similar to a taking are produced, though externally the situation remains unchanged. ${ }^{48}$ Lately, regulatory takings have been added to the lexicon of international law to designate those measures that relate to the exercise of the host-state's powers to govern the social and economical activity within its boundaries. This concept derives from the doctrine on the Fifth Amendment of the US Constitution, and although it has not yet been formally used in treaties, it can be recognised in modern forms of expropriation described as tantamount or equivalent to the latter. ${ }^{49}$ All these forms of indirect expropriation are subsumed in its elusive definition: state measures that are not openly expropriatory, but result in the deprivation of the property of an alien. ${ }^{50}$

The conceptual analysis of indirect takings only illustrates how they may appear in practice, but leaves its main question unanswered: at what point does a regulatory measure become compensable? Or, more precisely, which is the element or elements that determine the existence of an expropriation under international law? The only possible approach to this problem is case-by-case. Such an approach has

\footnotetext{
${ }^{46}$ Generation Ukraine, Inc. v. Ukraine, ICSID case No. ARB/00/9, Award, 16 September 2003, at para. 20.22, available at $<$ http://ita.law.uvic.ca/documents/GenerationUkraine 000.pdf $>$ (last visited 31 March, 2008).

${ }^{47}$ Reisman and Sloane, supra note 41, at 128-9.

${ }^{48}$ Sornarajah, supra note 3 , at 350 .

${ }^{49}$ Waelde and Kolo, supra note 8, note 46 at 821; and Z AlQurashi, 'Indirect Expropriation in the Field of Petroleum', (2004) 5/VI JWIT 897, at 901.

${ }^{50} \mathrm{See}$ A Newcombe, 'The Boundaries of Regulatory Expropriation in International Law', (2005) 20/I ICSID Rev. 1, at 10.
} 
been widely adopted in doctrine and expressly recognised in recent treaties. ${ }^{51}$ It is obviously not a methodology that is specific to the issue of indirect expropriation, but one that will be used in most instances in which an adjudicator applies legal standards to a particular set of facts. ${ }^{52}$ As Paulsson and Douglas point out:

[t]he only real guidance with respect to the threshold of interference for state measures affecting investments is the product of inductive generalizations from the findings of international tribunals and domestic courts as to the factual circumstances that give rise to a [...] taking. ${ }^{53}$

Decision-makers in international law normally refer to the statements of other tribunals. According to Article 38 of the Statute of the ICJ, judicial decisions are subsidiary means for the determination of the rules of law. Though not a proper source of international law, they will be generally treated as authoritative statements by other decision-makers. Judicial decisions will aid them settling a dispute in two situations: when there is no applicable treaty or clear interpretation of an existing one, and when it is not easy to ascertain the existence or meaning of an international custom or general principle of law. ${ }^{54}$

\footnotetext{
${ }^{51}$ G Christie, 'What Constitutes a Taking of Property under International Law?', (1962) BYIL 307, at 308; American Law Institute, Restatement of the Law Third. The Foreign Relations Law of the United States (1987), § 712, Reporter's Note 6, at 211; Dolzer and Stevens, supra note 16, at 100; AlQurashi, supra note 49, at 905; Paulsson and Douglas, supra note 8, at 146; B Kunoy, 'Developments in Indirect Expropriation Case Law in ICSID Transnational Arbitration', (2005) 6/III JWIT 467, at 467 \& 473; Newcombe, supra note 50, at 6; and M Gutbrod and S Hindelang, 'Externalization of Effective Legal Protection against Indirect Expropriation. Can the Legal Order of Developing Countries Live up to the Standards Required by International Investment Agreements? A Disenchanting Comparative Analysis', (2006) 7/I JWIT 59, at 63.

See, also, e.g., Art. Annex B of the 2004 Treaty Concerning the Encouragement and Reciprocal Protection of Investment between Uruguay and USA, available at $<$ http://www.unctad.org/sections/dite/iia/docs/bits/US_Uruguay.pdf> (last visited 31 March, 2008); or Annex B.13 (1) of the 2006 Agreement for the Promotion and Protection of Investments between Canada and Perú, available at <http://www.unctad.org/sections/dite/iia/docs/bits/canada peru.pdf> (last visited 31 March, 2008).

${ }^{52}$ Fortier and Drymer, supra note 8, at 314.

${ }^{53}$ Paulsson and Douglas, supra note 8 , at 146.

${ }^{54}$ See A Boyle and C Chinkin, The Making of International Law (2006), 293-300.
}

See, also, Pellonpää and Fitzmaurice, supra note 8, at 56; Brower and Brueschke, supra note 10, at $642-3$; and Sornarajah, supra note 3 , note 6 at $317 \& 351$. 
The PCIJ and the ICJ have seldom referred to indirect expropriation in their judgments. ${ }^{55}$ The case-law on this issue derives mainly from the ever-growing number of arbitral awards in investor-to-state disputes based on BITs or investment chapters of economic integration agreements (EIAs). ${ }^{56}$ Outside international investment law, the protection of property from deprivation has been normally addressed by regional human-rights bodies too, particularly in Europe. ${ }^{57}$ Important judicial decisions for the international law of expropriation also emerge from ad hoc dispute-settlement institutions, most notably the Iran-United States Claims Tribunal (Iran-US CT). ${ }^{58}$ The case-law of domestic courts in the US is highly instructive as well, and should not be overlooked in any study on the law of indirect expropriation. $^{59}$

Two doctrines provide guidelines on the threshold problem, i.e. that of defining the boundaries between non-compensable regulatory measures and indirect takings. ${ }^{60}$ The first one has been identified as the sole-effect doctrine. According to this position, the central factor for establishing whether an indirect taking has occurred is the result of the governmental measures on the affected property. The purpose of these measures is not essential to this determination, nor is the fact that the actual title of the asset remains with the owner. This view goes back to the 1922 Norwegian

\footnotetext{
${ }^{55}$ See Chapter 7 infra.

${ }^{56}$ See Chapters 5 and 6 infra.

${ }^{57}$ See Chapter 3 infra.

${ }^{58}$ See Chapter 4 infra.

${ }^{59}$ See Chapter 6 infra.
}

${ }^{60}$ See, e.g., M Brunetti, 'Indirect Expropriation in International Law', (2003) 5/III FORUM 150, at 151; R Dolzer, 'Indirect Expropriations: New Developments?', (2003) 11 NYU ELJ 64, at 79-80;

R Dolzer and F Bloch, 'Indirect Expropriation: Conceptual Realignments?', (2003) 5/III FORUM 155, at 158; Fortier and Drymer, supra note 8, at 300; V Heiskanen, 'The Contribution of the Iran-United States Claims Tribunal to the Development of the Doctrine of Indirect Expropriation', (2003) 5/III FORUM 176, at 176-8; A Weiner, 'Indirect Expropriations: The Need for a Taxonomy of "Legitimate" Regulatory Purposes', (2003) 5/III FORUM 166, at 166; Kunoy, supra note 51, at 471; Newcombe, supra note 50, at 5-6, 9-10, 22, \& 25-9; Gutbrod and Hindelang, supra note 51, at 63-6; V Heiskanen, 'The Doctrine of Indirect Expropriation in Light of the Practice of the Iran-United States Claims Tribunal', (2007) 8/II JWIT 215, at 217; and U Kriebaum, supra note 35, at 724-9. 
Shipowners claim and the 1928 Chorzow Factory case. ${ }^{61}$ The sole-effect approach has received the implied support of many scholars. ${ }^{62}$ Its constitutive elements are already found in the concept of indirect taking given by Christie in the 1960s:

[an] interference with an alien's property [that] amount[s] to expropriation even when no explicit attempt is made to affect the legal title to the property, and even though the respondent State may specifically disclaim any such intention. ${ }^{63}$

The second position is the so-called police powers doctrine. Besides the effect on the alien's property, it takes into account the purpose and context of the respective measures when establishing whether the regulatory action of the state amounts to an indirect expropriation. This doctrine maintains that non-discriminatory measures adopted for a legitimate public purpose are necessarily lawful under international norms, and do not give rise to compensation. ${ }^{64}$ The police-powers solution can be traced back to the 1934 Oscar Chinn case. ${ }^{65}$ It has been recently endorsed by lastgeneration US BITs and free trade agreements (FTAs).

Both positions offer useful guidance to any decision-maker addressing the threshold problem. However, choosing one doctrine or the other is not indifferent for the chief actors of international investment law. Dolzer and Stevens explain that:

to the investor, the line of demarcation between measures for which no compensation is due and actions qualifying as indirect expropriations may well make

\footnotetext{
${ }^{61}$ See Christie, supra note 51, at 311; Higgins, supra note 5, at 323; Sedigh, supra note 8, at 647; and Reisman and Sloane, supra note 41, at 119-20.

For an early exposition of the sole-effect position, see Herz, supra note 1, at $248 \& 253$.

${ }^{62}$ See, e.g., Higgins, supra note 5, at 331; Waelde and Kolo, supra note 8, at 824-5, 827, \& 846; Dinstein, supra note 8, at 869; F Orrego Vicuña, 'Carlos Calvo, Honorary NAFTA Citizen', (2002) 11 NYU ELJ 19, at 27; B Appleton, 'Regulatory Takings: The International Law Perspective', (2003)11 NYU ELJ 35, at 37; I Madalena, 'Foreign Direct Investment and the Protection of the Environment: the Border between National Environmental Regulation and Expropriation', (2003) 12/III Eur. ELR 70, at 70; Reisman and Sloane, supra note 41, at 130 \& 141; A Redfern and M Hunter, Law and Practice of International Commercial Arbitration (2004), 586-7, \& 588-9; Paulsson and Douglas, supra note 8, at 158; Kunoy, supra note 51, at 468 \& 474; and Gutbrod and Hindelang, supra note 51, at 66 .

${ }^{63}$ Christie, supra note 51 , at 309.

${ }^{64}$ Heiskanen (2003), supra note 60, at 177.

${ }^{65}$ See Dolzer and Bloch, supra note 60, at 159.

An embryonic version of this view can be found in Dunn, supra note 1, at 180 .
} 
the difference between the burden to operate (or abandon) a non-profitable enterprise and the right to receive full compensation (either from the host State or under an insurance contract). For the host State, the definition determines the scope of the State's power to enact legislation that regulates the rights and obligations of owners in instances where compensation may fall due. ${ }^{66}$

The sole-effect position clearly stresses the interests of the foreign investors; its counterpart, those of the host-state. ${ }^{67}$ The present work investigates which of these two doctrines conform to international law -particularly, to its rules on the protection of aliens, and the international minimum standard of treatment on which they are based. For this purpose, six chapters -excluding the introduction and conclusionstudy the international law of expropriation: from the early protection of aliens in the law of nations, to the debate on compensation for takings, and beyond. They focus on the sophisticated solutions on indirect takings adopted in the different fora of contemporary international law in which property and its deprivation have been addressed.

Chapter two outlines the evolution of the law of expropriation in the $19^{\text {th }}, 20^{\text {th }}$ and $21^{\text {st }}$ centuries. A forum-based analysis of indirect takings follows this introductory part. Interferences with property under international human rights law are studied in chapter three. It traces the difficulties in the incorporation of property as a human right in multilateral instruments and its progressive recognition in the regional systems of Europe, the Americas and Africa. This chapter is centred, however, focuses on the development of the protection of property by the European Commission and Court of Human Rights. The case-law on expropriation of the IranUS CT is analysed in chapter four, which deals with its definition of property and

\footnotetext{
${ }^{66}$ Dolzer and Stevens, supra note 16 , at 99-100.

${ }^{67}$ See Waelde and Kolo, supra note 8, at 822-3.
} 
expropriation; other measures affecting property rights; the contours of indirect takings; and its conditions of legality and their consequence.

Foreign investment and its taking, as regulated in bilateral treaties and construed in international arbitration, are examined in chapter five. The conventional notions of investment and expropriation are seen through the eyes of their drafters and interpreters. International investment law, however, does not only derive from bilateral agreements. Chapter six studies the multilateral treaties that deal with property and its expropriation, as well as the failed attempts to regulate them and relevant soft-law instruments on the topic. Chapter seven offers a legal analysis of the sole-effect/police-powers controversy. It explains the rationale behind the rules on expropriation in international law, and looks at the latest shift in the debate over the protection of aliens. This last part of the work gives an interpretation on the concept of fair and equitable treatment, and traces its main elements in international investment arbitrations. The interaction between this protection and that against indirect takings is also addressed in this chapter.

The present thesis deals with indirect takings, but is ultimately about the property of aliens in the law of nations. It attempts to answer the threshold question from the standpoint of the minimum standard on which its protection is based; a standard that lies at the heart of the international law on expropriation, and international investment law in general. 


\section{FROM COMPENSATION TO INDIRECT TAKINGS}

Historical and ideological differences between capital-exporting and capitalimporting states explain the long debate on the payment of compensation for expropriation in the law of nations. According to developed states, an international minimum standard stressing the need for a prompt, adequate and effective compensation is required in case of taking of foreign property. Under this standard, the owner should receive the full value of his lost investment. Against it, developing and communist states, as well as those countries that gained their independence from colonial rule in the aftermath of the Second World War, proposed a national standard. Articulated during the process of nationalisation of foreign property, it was later developed by the UN General Assembly resolutions that asserted the principle of permanent sovereignty of the state over its natural resources and the concept of new international economic order (NIEO). This new alternative standard required an adequate or appropriate compensation that would consider all the relevant circumstances surrounding each particular taking. The determination of this compensation should be left to the expropriating state, in conformity with its municipal law, and would range from the full value of the taken property to none, depending on each particular case.

While these two views on the compensation for the taking of aliens' property collided at the UN, significant changes in international economy and politics gradually moulded state policies, legislation, and international practice on foreign 
investment. The collapse of communism and the progressive liberalisation of national and international economy led erstwhile statist-orientated countries to desire it. They enacted, for this purpose, investment codes, and concluded international agreements that protect foreign investors in the traditional terms advanced by capitalexporting states. Both the national and international treatment standards were included in these treaties. This meant the defeat of the exclusive standard of national treatment put forward by second and third world countries. They also discarded their position on compensation in these treaties, part of which had achieved international consensus at the UN in 1962. This situation and the increased governmental regulation in areas formerly ran by the state, like the industrial exploitation of natural resources, or of current public concern, like the protection of the environment, have modified the nature of the international legal debate. The always relevant problem of compensation has given way to that of indirect takings, as the most controversial issue in the law of expropriation today.

The present chapter deals with the classical international norms on takings and their challenges. These include the $19^{\text {th }}$ century Calvo doctrine and clause; the 1917 Russian revolution; the Mexican constitution of the same year; the nationalisations of the second half of the $20^{\text {th }}$ century and their lump-sum agreements. They also include the diplomatic controversy on the permanent sovereignty over natural resources and the NIEO that took place at the UN in the 1960s and 1970s. An introduction to the current doctrinal debate in the international law of expropriation completes this brief historical survey on the protection against takings. 


\subsection{Calvo doctrine and nationalisations}

Prior to the Second World War, imperial-powers provided the necessary degree of legal and administrative certainty to those investing in their colonial territories through their domestic laws and institutions. ${ }^{68}$ For those investing in noncolonial territories, mainly independent Latin American countries, the US and the imperial-powers developed an absolute international standard of treatment. ${ }^{69}$ According to it, aliens should be granted a minimum degree of protection, regardless of how the nationals of the host-state country were treated by their own authorities. Against this principle, Latin American states advanced the relative standard of national treatment. In conformity with it, aliens should not be treated differently from the nationals of the country that hosted them. ${ }^{70}$ The classical norms on the responsibility of states derive from this dispute, which explains why there was normally no distinction in the past between the rules of state responsibility and the substantive rules of treatment of aliens in the writings of scholars and the practice of states. Today, it is generally acknowledged that these two types of norms refer to different, but related, areas of international law. ${ }^{71}$

By the end of the $20^{\text {th }}$ century, the so-called international minimum standard had prevailed. ${ }^{72}$ Non-compliance with it by the host government makes it now liable

\footnotetext{
${ }^{68}$ On this period, see, in general, Sornarajah, 'Power and Justice in International Law', (1997) 1 SJICL 28, at 54-5; and Sornarajah, supra note 3, at 18-20.

${ }^{69}$ Vattel had already advocated this principle in the $18^{\text {th }}$ century. Sornarajah, supra note 3, note 34 at 19.

${ }^{70}$ This principle can be traced back to the works of Vitoria in the $16^{\text {th }}$ century. Ibid., 18-9.

${ }_{72}^{72}$ See A Cassese, International Law (2005), 243-4.

${ }^{72}$ See R Higgins, Problems \& Process. International Law and How We Use It (1994), 159; P Malanczuk, Akehurst's Modern Introduction to International Law (1997), 256; and Cassese, supra note 71 , at 121 .
} 
under the international law of state responsibility. The authorities infringing an international obligation are responsible for that breach and have to repair it. The government of the injured foreigner is entitled to ask for reparation through diplomatic means. ${ }^{73}$ It can resort to self-help, in the form of non-forcible action, so as to constrain the other state to correct the wrong, or even punish it for the violation of the international norm. Such action might take the form of economic sanctions, or the suspension or termination of a treaty, among other possibilities. Forcible measures involving armed reprisals and war were also an option in classical international law. ${ }^{74}$ Not anymore.

Also known as international standard of justice, the principle advanced by the US and Western European states was first described by the US-Mexican General Claims Commission in the 1926 Neer case:

[...] the treatment of an alien, in order to constitute an international delinquency, should amount to an outrage, to bad faith, to wilful neglect of duty, or to an insufficiency of governmental action so far short of international standards that every reasonable and impartial man would readily recognize its insufficiency. ${ }^{75}$

In its early formulations, this international standard included certain protections: that against denial of justice; indecent treatment if imprisoned; disorders, violence and deportation in abusive ways; and expropriation. ${ }^{76}$ The latter did not mean that the host-state had no right to take the property of aliens. It meant that the host-state could only take his property if the respective measure was lawful, i.e. if it

\footnotetext{
${ }^{73}$ See Malanczuk, supra note 72 , at 256-7.

Classical international law refers to the body of rules that existed before the Second World War. Those created in the ensuing years constitute contemporary international law.

See J Pastor Ridruejo, Curso de Derecho Internacional y Organizaciones Internacionales (2000), 5963.

${ }^{74}$ See, e.g., the 1902 dispute between Venezuela, on one side, and Great Britain, Germany and Italy, on the other, at note 85 infra.

${ }^{75}$ US-Mexican General Claims Commission, (1926) 4 RIAA 60, or (1927) AJIL 555.

${ }^{76}$ D Vagts, 'Minimum Standard', in R Berhardt (ed.), EPIL (1997), Vol. III, at 408.
} 
was adopted following three requirements: for public purposes, without discrimination, and accompanied by compensation. ${ }^{77}$

\subsubsection{Against the international standard}

The institution of diplomatic protection has its origins in the relations between Latin America and the US. In other parts of the world, like Africa and Asia, the system of extraterritorial jurisdiction had been employed to protect the rights of aliens. For instance, nationals of some European countries in the Ottoman empire benefited from so-called capitulations, by which the Sultan allowed them to be subject to the law of their nationality, and not to Ottoman law. ${ }^{78}$ But it was not only diplomatic protection that developed from the relations of Latin American states and the US -later joined by Western European countries. So did its negation. ${ }^{79}$ The initial assault on the $19^{\text {th }}$ century international protection of aliens came from Argentina, and took the name of Calvo doctrine. It proposed the standard of national treatment, derived from the principles of non-intervention and sovereign equality of states. ${ }^{80}$ This doctrine was an application of the principle of non-discrimination, both as a

\footnotetext{
${ }^{77}$ See R Dolzer, 'New Foundations of the Law of Expropriation of Alien Property', (1981) 75/III AJIL 553, at 557-8; P Norton, 'A Law of the Future or a Law of the Past? Modern Tribunals and the International Law of Expropriation', (1991) 85 AJIL 474, at 475-6; and A Cassese, International Law in a Divided World (1994), 317-320.

${ }^{78}$ See D Shea, The Calvo Clause: A Problem of Inter-American and International Law and Diplomacy (1955), 4-5, and 9-11; and D Quataert, The Ottoman Empire 1700-1922 (2006), 78-9.

See, also, Sornarajah, supra note 3, at 347-8.

${ }^{79}$ See Shea, supra note 78, at 20.

${ }^{80} \mathrm{See}$, in general, C Calvo, Le Droit International Théorique et Pratique (1896).

The doctrine was first stated in the 1868 Spanish version of this treatise.

M Garcia-Mora, 'The Calvo Clause in Latin American Constitutions and International Law', (1950) 33/IV MLR 205, at 205-6.

See, also, Shea, supra note 78, at 16-21.
} 
minimum and maximum standard of treatment. ${ }^{81}$ Calvo did not consider the content of the international standard to be unacceptable. He only claimed that both nationals and non-nationals of the host-country should be protected by the domestic law of the latter. As a consequence, disputes arising from its application should be settled by the courts of this state, under its municipal norms. ${ }^{82}$

The Calvo doctrine originated in the negative perception held in Latin America towards US foreign investment. Sornarajah explains that in this region:

foreign investment and the claims relating to the international law that protected it were perceived as instruments through which the United States was able to maintain its economic dominance in the region. [...] The idea that there were supranational norms which permitted the protection of the foreign investor was anathema to the Latin American jurists who argued that only protection that existed for foreign investment was to be found in the domestic legal systems of the host state. ${ }^{83}$

Not surprisingly, the US itself had embraced this position when it was a recipient of investment from Europe. Its authorities only changed their mind when the US became an exporter of capital into Latin America. ${ }^{84}$ European countries investing in the region also adopted the international minimum standard. In its name, capital-exporting states abusively exercised their right of diplomatic protection in Latin America during the late $19^{\text {th }}$ and early $20^{\text {th }}$ centuries. The most famous example of abuse was the naval blockade of the Venezuelan coast by Germany, Italy and the United Kingdom in 1902, who demanded reparation for Venezuela's sovereign-debt

\footnotetext{
${ }^{81}$ See F Francioni, 'Compensation for Nationalisation of Foreign Property: The Borderline between Law and Equity', (1975) 24/II ICLQ 255, at 269.

${ }^{82}$ See N Schrijver, Sovereignty over Natural Resources. Balancing Rights and Duties (1997), 178.

See, also, R Bishop, J Crawford and M Reisman, Foreign Investment Disputes. Cases, Materials and Commentary (2005), 3; and J Paulsson, Denial of Justice in International Law (2005), 20-1.

${ }^{83}$ Sornarajah, supra note 3, at 145-6.

${ }^{84}$ Ibid., 146.
} 
default and damages for their nationals. ${ }^{85}$ Calvo's theory was a direct reaction to this type of situations. ${ }^{86}$

As a corollary to his doctrine, Latin American countries inserted a clause in those concession contracts concluded with foreigners, by which the alien waived the right of diplomatic protection. ${ }^{87}$ Known as the Calvo clause, it meant that a foreign investor would be in the same position as a local one, both subject to the exclusive jurisdiction of the host state's courts at the moment of determining their rights and obligations. ${ }^{88}$ Article 9 paragraph 2 of the 1934 Montevideo Convention on the Rights and Duties of States illustrates the doctrine, when it stated that "[n]ationals and foreigners are under the same protection of the law and the national authorities and the foreigners may not claim rights other or more extensive than those of the nationals". ${ }^{89}$ Examples of the Calvo clause also include Article 21 of the 1892 Treaty of Friendship, Commerce and Navigation between Colombia and Italy, and Article 7 of the 1948 American Treaty of Pacific Settlements (Pact of Bogotá). The ColombiaItaly FCN provided that:

Both Contracting Parties wish to avoid disputes which could affect their friendly relationship and agree that in connection with disputes involving private parties arising out of criminal, civil or administrative matters, their diplomatic agents will abstain from intervention, save in case of denial of justice or extraordinary unlawful delay in the administration of justice. ${ }^{90}$

The Pact of Bogotá says:

\footnotetext{
${ }^{85}$ See, in general, M Silagi, 'Preferential Claims against Venezuela Arbitration', in R Bernhardt (ed.), EPIL (1997), Vol. III.

${ }^{86} \mathrm{~F}$ Garcia-Amador, 'Calvo Doctrine, Calvo Clause', in R Bernhardt (ed.), EPIL (1992), Vol. I, at 521.

See Shea, supra note 78, at 11-6.

${ }^{87}$ Garcia-Mora, supra note 80, at 206; Garcia-Amador, supra note 86, at 522; and Cassese, supra note 77 , at 50 .

${ }^{88}$ Redfern and Hunter, supra note 62 , at 562.

${ }^{89}$ Available at <http://www.yale.edu/lawweb/avalon/intdip/interam/intam03.htm> (last visited 31 March, 2008).

See Garcia-Amador, supra note 86, at 521.

${ }^{90}$ Quoted in Paulsson, supra note 82, at 22.
} 
The High Contracting Parties bind themselves not to make diplomatic representations in order to protect their nationals, or to refer a controversy to a court of international jurisdiction for that purpose, when the said nationals have had available the means to place their case before competent domestic courts of the respective State. ${ }^{91}$

Although the debate over the Calvo clause developed almost exclusively in the Americas, it became one of the most controversial issues in international law. ${ }^{92}$ Overall, this doctrine has not been generally well received in the international fora. ${ }^{93}$ The PCIJ recognised diplomatic protection as a right of the state, derived from international law, in the Mavrommatis case. ${ }^{94}$ Critics of the Calvo clause have referred to this judgment to conclude that diplomatic protection cannot be renounced by nationals. Several claims commissions and courts have dealt with the validity of the clause. The most famous of these cases is North American Dredging Company of Texas, settled by the US-Mexican General Claims Commission in $1926 .{ }^{95}$ In this landmark case, the tribunal adopted the rule known as limited validity of the Calvo clause, and thus avoided having to choose between upholding it altogether or denying its efficacy completely. According to this rule, there is no generally accepted norm of international law forbidding an individual to relinquish, to any extent and under any circumstances or conditions, the protection of his government. Although the individual would be legally bound by the clause to which he contractually agreed, the state of his nationality would not be bound by an agreement to which it was not a

\footnotetext{
${ }^{91}$ Available in Spanish at <http://www.oas.org/juridico/spanish/tratados/a-42.html $>$ (last visited 31 March, 2008).

${ }^{92}$ Shea, supra note 78 , at 6-7.

${ }^{93}$ See Shea, supra note 78, at 20-1; F Graham, 'The Calvo Clause: Its Current Status as a Contractual Renunciation of Diplomatic Protection', (1970) 6 Tex. ILF 289, at 295-7; and Schrijver, supra note 82 , at $178-80$.

${ }_{94}^{92}$ Mavrommatis Palestine Concessions (Greece v UK), PCIJ, Judgment, 30 August 1924, (1924) PCIJ Rep. Series B No 3.

${ }^{95}$ US-Mexican General Claims Commission, (1926) 4 RIAA 26.

See Shea, supra note 78, at 198-211; Graham, supra note 93, at 296-7; and Paulsson, supra note 82, at 29-32.
} 
party. In other words, his government would not be deprived from exercising its right of diplomatic protection. The Calvo clause would therefore only insist on the requirement of the exhaustion of local remedies before such an exercise. In practice, this solution downgraded the clause to an altogether superfluous provision, repeating a condition already included in the general rules of admissibility of diplomatic protection. ${ }^{96}$ Other judicial decisions followed this view.

In 2006, the ILC expressly decided "to leave open the question whether the State exercising diplomatic protection does so in its own right or that of its national or both". ${ }^{97}$ The ILC's Articles on Diplomatic Protection acknowledged that the Calvo clause was viewed as a regional custom in Latin America and "formed part of the national identity of many States". ${ }^{98}$ Nevertheless, it failed to recognise that several Latin American countries have enacted national legislation to promote the flow of investment into their economies, and that, as Schrijver points out:

[t]he changing attitude of a number of Latin American countries towards foreign investment is also reflected in their increasing participation in multilateral investment instruments such as ICSID and MIGA as well as in the increasing number of bilateral investment treaties they have concluded in recent years. ${ }^{99}$

The ILC did, however, recognise that capital-exporting states have vigorously disputed the validity of this clause. Quoting North American Dredging Company of Texas, the ILC finally endorsed the limited validity of the Calvo clause, as put forward in that case, expressly stating that this clause:

is difficult to reconcile with international law if it is to be interpreted as a complete waiver of recourse to international protection in respect of an action by the host State constituting an internationally wrongful act (such as denial of justice) or where the

\footnotetext{
${ }^{96}$ See Cassese, supra note 77 , at 50 .

See, also, Graham, supra note 93, at 296; and Schrijver, supra note 82, at 179-80.

${ }^{97}$ Report of the ILC, Fifty-eighth Session (1 May - 9 June and 3 July - 11 August 2006), Official Records of the UNGA, Sixty-first Session, Supplement No. 10 (A/61/10), at 26. See note 23, supra.

${ }^{98}$ Ibid., at 73-4.

${ }^{99}$ Schrijver, supra note 82 , at 181.

See, also, Paulsson, supra note 82 , at 27-9.
} 
injury to the alien was of direct concern to the State of nationality of the alien. The objection to the validity of the 'Calvo clause' in respect of general international law are certainly less convincing if one accepts that the right protected within the framework of diplomatic protection are those of the individual protected and not those of the protecting State. ${ }^{100}$

\subsubsection{The road to lump-sum agreements}

Two events would further undermine the international protection of foreign investment. Until 1917, the right of private property was recognised by the municipal legislation of almost every state. It was also protected by the international minimum standard, complemented by a non-exclusive national standard of treatment. Those Latin American countries that supported the Calvo-doctrine version of the latter, i.e. national treatment as an exclusive standard, were the sole exception to the general rule. This consensus among nations was broken by the Russian Revolution and its repudiation of the right of private property. The newly-created Soviet Union introduced to the international lexicon the term nationalisation to designate expropriations of a general character. ${ }^{101}$ Subsequent takings of the property of Russian nationals and foreigners, without compensation, followed. The communist authorities justified the lack of payment to aliens invoking the principle of national treatment. Western states only came slowly to terms with the Soviet nationalisations, but never formally accepted these measures as legal. ${ }^{102}$

Another revolution, this time in Mexico, led to the establishment of the social function of property at a constitutional level. In the early $20^{\text {th }}$ century, Mexican law

\footnotetext{
${ }^{100}$ See note 23, supra, at 73-4.

${ }^{101}$ Sometimes called "socialisations". Brownlie, supra note 15 , at 513.

${ }^{102}$ R Dolzer, 'Expropriation and Nationalization', in R Bernhardt (ed.), EPIL (1995), Vol. II, 320; and A Lowenfeld, International Economic Law (2003), 392-3.
} 
was built on individualism and private property as an absolute, untouchable right. ${ }^{103}$

One of the main purposes of the revolution that started in 1910 was the redefinition of this approach. ${ }^{104}$ The 1917 constitution, still in force in Mexico, achieved such an objective in its article 27 , which provides:

Ownership of the lands and waters included within the boundaries of the national territory belongs originally to the Nation, which has had and continues to have the right to transmit ownership thereof to private parties, thereby constituting private property.

Expropriations may only be made for reasons of public utility and by means of compensation.

The Nation shall have at all times the right to impose on private property the modalities required by public interest, as well as to regulate, for social benefit, the exploitation of natural resources capable of appropriation, in order to make an equitable distribution of public wealth, conserve them, achieve the balanced development of the country and improve the life conditions of the rural and urban population. $^{105}$

This remodelled notion of property, subordinated to the common welfare of the society, was in no case a new concept in the history of law. The social function of property had already been advanced by St. Thomas Aquinas in the medieval ages, and included in the influential Napoleonic civil code of the XIX century France. ${ }^{106}$ Although the Mexican version did not mean expropriation without compensation, it meant, as Lowenfeld points out:

distinctions between state-taking of a private home where a school or highway was to be built, and state ownership (or acquisition of ownership) of a major industry, such as electric power generation, petroleum exploration, or railroads. For the former, compensation, generally prior and more or less in full value, was contemplated, if not always implemented. For the latter, as well as for redistribution of land pursuant to agrarian reform programs, compensation was not excluded, but it need not be prior or prompt, and the state's ability to pay was an important factor in determining what level of compensation was appropriate. ${ }^{107}$

\footnotetext{
${ }^{103}$ Lowenfeld, supra note 102 , at 393-4.

${ }^{104}$ See Dunn, supra note 1, at 168-9.

${ }^{105}$ Available in Spanish at <http://pdba.georgetown.edu/Constitutions/Mexico/mexico1917.html> (last visited 31 March, 2008).

${ }^{106}$ Higgins, supra note 5, at 274-5.

${ }^{107}$ Lowenfeld, supra note 102, at 394
} 
The famous 1938 diplomatic exchange between the governments of the USA and Mexico, derived from the 1917 agrarian expropriations and 1938 nationalisation of the oil industry in the latter, summarised the opposed positions of capitalexporting and capital-importing countries regarding the issue of compensation. Reaffirming the principles of national and international treatment, the US Secretary of State, Cordell Hull, declared that "no government is entitled to expropriate private property, for whatever purpose, without provision for prompt, adequate, and effective payment therefore". ${ }^{108}$ Hull referred to this formula as the principle of just compensation, then extensively accepted in comparative constitutional law. ${ }^{109}$ Prompt, adequate and effective meant that compensation should not only correspond to the value of the property taken, but should also be paid speedily to the owner in a transferable currency. ${ }^{110}$ Mexico distinguished expropriations from nationalisations, admitted that only adequate compensation was due, and insisted on the Calvo doctrine, declaring -in the words of Cassese- that "international law only required $[\ldots]$ foreigners to be treated no less favourably than $[\ldots]$ nationals, and [that] the time and manner of payment must be determined under the laws of the expropriating State". 111

Eventually, Mexico and the USA agreed on the compensation to be paid, each insisting on their respective legal positions until the end. ${ }^{112}$ In the following years, nationalisations occurred in Eastern Europe, former Western colonies, and Latin America. All the countries under communist control nationalised private property,

\footnotetext{
${ }^{108}$ Ibid., 400.

${ }^{109}$ Ibid.

${ }^{110}$ See Chapter 5 infra.

${ }^{111}$ Cassese, supra note 71523.

${ }^{112}$ Dolzer and Stevens, supra note 16, at 320; and Vagts, supra note 76, at 409.

See, also, Herz, supra note 1, at 258.
} 
whether owned by their own citizens or by foreigners. For instance, Bulgaria, Czechoslovakia, Hungary and Poland, from 1945 to 1948; China, from 1949 to 1957; and Cuba, from 1959. ${ }^{113}$ In the decolonised states of Africa and Asia, as in Latin American countries, nationalisations befell on major natural resources. The AngloIranian Oil Company's properties in Iran, for example, were nationalised in 1951; the Suez Canal Company in Egypt in 1956; and Dutch properties in Indonesia in 1958-9. In the early 1970 s, nearly all the Arab states abrogated the concessions of the major Western oil companies or directly nationalised them. As to Latin America, mines and other major enterprises were subject to general expropriations in Argentina, Bolivia, Brazil, Chile, Guatemala, Perú, among other states. ${ }^{114}$

Expropriations were followed by state-to-state or state and former-owner negotiations, sometimes with the participation of intermediaries, like the World Bank which offered its good offices in the negotiations between Egypt and the Suez Canal Company. ${ }^{115}$ Negotiations normally led to lump-sum agreements. Through these treaties, the expropriating state allocated a single sum of money, determined on the basis of various criteria, which generally met halfway the conflicting interests of the two countries concerned. ${ }^{116}$ Lump-sum agreements settled, in a definitive form, difficult disputes arising from nationalisations, and were concluded in large numbers: around 200, since the end of the Second World War. ${ }^{117}$ They involved a compromise where the seized property was never returned, and the amounts given were lower than those originally claimed by the disposed foreigner. The negotiations which took

\footnotetext{
${ }^{113}$ See Comeaux \& Kinsella, supra note 3, at 63-4.

See, also, Bishop, Crawford and Reisman, supra note 82, at 4.

114 See Lowenfeld, supra note 102, at 405.

See, also, Bishop, Crawford and Reisman, supra note 82, at 5.

${ }^{115}$ Lowenfeld, supra note 102, at 405.

${ }^{116}$ Cassese, supra note 71 , at 525.

${ }^{117}$ R Lillich, 'Lump Sum Agreements', in R Bernhardt (ed.), EPIL (1997), Vol. III, at 269.
} 
place to conclude these treaties with the UK and USA, for instance, were described by Lowenfeld as follows:

In the case of the nationalizations in Eastern Europe, [...] the United States negotiated so-called 'lump-sum agreements' with each state, between 1948 (Yugoslavia) and 1982 (Czechoslovakia), under which the taking state kept the property but agreed to payment of stated sums over an extended period, and the United States agreed to adjudicate the claims of eligible former owners and make pro rata payments to them out of the funds recovered. In most cases the United States held some 'bargaining chips', such as frozen assets or promise of economic assistance. The United Kingdom also negotiated lump-sum agreements with the Eastern European states as well as Egypt but, with fewer bargaining chips (and less willingness to jeopardize its position as a financial center by blocking bank accounts), settled sooner than the United States and generally for lesser amounts relative to the value of the properties in question. ${ }^{118}$

Lump-sum agreements were concluded almost exclusively under political and economic considerations. For the host-state, law played a role only at the moment of deciding whether to take the measure, negotiate settlements and pay compensation. ${ }^{119}$ Sole-arbitrator Dupuy, in the Topco/Calasiatic case, considered lump-sum agreements to have no evidentiary value in international law because they were "inspired basically by considerations of expediency and not of legality". ${ }^{120}$ The Iran-US CT reached a similar conclusion in a number of its decisions. ${ }^{121}$ This circumstance introduced even more uncertainty to an already inefficient protection against expropriation, for none of the available solutions on the treatment of foreign investors offered a reliable picture of practice, and none was completely irrelevant. ${ }^{122}$

\footnotetext{
${ }^{118}$ Lowenfeld, supra note 102 , at 406.

${ }^{119}$ Ibid.

${ }^{120}$ Texas Overseas Petroleum Co. \& California Asiatic Oil Co. (Topco/Calasiatic) v Libyan Arab Republic, Dupy, sole arbitrator, Award, 19 January 1977, (1978) 17 ILM 1, para 69.

${ }^{121}$ See Mouri, supra note 10, at 354-7.

${ }^{122}$ Lowenfeld, supra note 102, at 406.
}

See, also, Sacerdoti, supra note 8, at 391; Lowenfeld, supra note 102, at 407; and Sornarajah, supra note 3 , at 22 . 


\subsection{The law of expropriation at the UN}

The spread of communism after 1945 and the newly obtained sovereignty of several African and Asian states after the decolonisation process ${ }^{123}$, led to a globalisation of the long-standing conflict between the US and Western Europe, and the Latin American states. ${ }^{124}$ Capital-importing countries blamed the weakness of their national economies on the foreign control over key industries and major natural resources, which were seen as vital for the welfare of the population and the security of the state. They concluded that their political independence was nothing but formal, and that the only way to achieve an authentic sovereignty was by gaining economical independence from developed states. ${ }^{125}$ This meant, in practice, the extension of the public sector through the nationalisation of both industries and natural resources, and the establishment of state monopolies. ${ }^{126}$

The classical international law of expropriation was aimed at protecting physical persons from situations involving individual takings. It soon proved to be inadequate to solve the new problems posed by these expropriatory measures of a general character. Former European-colonies claimed that the traditional rules of international law, in which formation they took no part, did not reflect their own cultural and legal traditions. ${ }^{127}$ They rejected the international minimum standard and supported the Calvo doctrine developed in Latin America. ${ }^{128}$ In an effort to assert

\footnotetext{
123 Along with some small countries in the Americas, like Barbados, Belize, Guyana, Jamaica, Surinam, and Trinidad \& Tobago, amongst others.

${ }^{124}$ See Sornarajah, supra note 68 , at 50 \& 54.

${ }^{125}$ See D Carreau and P Juillard, Droit International Économique (2003), 403. See, also, Bishop, Crawford and Reisman, supra note 82, at 3.

${ }^{126}$ See Cassese, supra note 71 , at 524; and UNCTAD, supra note 19 , at 7.

${ }^{127}$ Norton, supra note 77 , at 478.

${ }^{128}$ Sornarajah, supra note 3 , at $38,140-2$, \& 145-6.
} 
multilaterally the concept of economical independence at an international level, the capital-importing states challenged customary law at the UN. Technically, the resolutions of its General Assembly do not constitute a source of international law. Nevertheless, they can evidence customary norms, since they reflect the views of the states voting for it. ${ }^{129}$ As the ICJ declared in its 1996 Advisory Opinion on the Legality of the Threat or Use of Nuclear Weapons:

General Assembly resolutions, even if they are not binding, may sometimes have normative value. They can, in certain circumstances, provide evidence important for establishing the existence of a rule or the emergence of an opinion iuris. To establish whether this is true of a given General Assembly resolution, it is necessary to look at its content and the conditions of its adoption: it is also necessary to see whether an opinion iuris exists as to its normative character. Or a series of resolutions may show the gradual evolution of the opinion iuris required for the establishment of a new rule. ${ }^{130}$

The attempt of capital-importing states to modify customary international law was, then, well-aimed. The result of their effort was, however, inconclusive.

\subsubsection{Sovereignty and natural resources}

Gaining control over natural resources was one of the main motives that drove European states like Portugal, Spain, the Netherlands, the UK, France, and later Germany and Italy, to colonise overseas territories throughout the world. ${ }^{131}$ The exploitation of these resources was considered unlimited, and was left, almost exclusively, to the colonising state. ${ }^{132}$ During this period, the flow of assets within imperial limits was sufficiently protected by the laws of the correspondent power.

\footnotetext{
${ }^{129}$ Malanczuk, supra note 72 , at 52.

${ }^{130}$ Advisory opinion on the legality or the threat or use of nuclear weapons, ICJ, 8 July 1996, (1996) 35 ILM 809, at 826, para. 70.

${ }^{131}$ B Brower, 'Natural Resources, Sovereignty over', in R Bernhardt (ed.), EPIL (1997), Vol. III, 520.

${ }^{132}$ See, in general, M Hartwig, 'Colonies and Colonial Régime', in R Bernhardt (ed.), EPIL (1992), Vol. I.
} 
There was no need for an international law on foreign investment in these regions, and the making of these rules was restricted to the relations of the Latin American states and the US, and later European countries. ${ }^{133}$ After the decolonisation process of the second half of the $20^{\text {th }}$ century took place, it was only a matter of time until the newly independent states of Africa and Asia would espouse their claim to permanent sovereignty over natural resources to that of communist and Latin American countries. As Waelde recalls, the world was divided in this period in separate blocks: "[t]he rich and exploitative "North", on one side, and "the underveloped and striving 'South', and the sympathetic socialist countries", on the other. ${ }^{134}$ The theoretical link between the communist and developing countries' position was based on the right of self-determination, central to the decolonisation process and the notion of permanent sovereignty over natural resources, first referred by the Marxist-Leninist Declaration of Rights of the Operative and Exploited People of 10 July, $1918 .^{135}$ The reliance of capital-exporting states on property rights and the sanctity of contracts was challenged by capital-importing countries, who considered the right of economic self-determination of a state to outweigh any other. Claiming that full compensation in case of expropriation would turn any major restructuring of a national economy impossible, capital-importing states questioned classical international law and tried to establish customary rules of expropriation through UN General Assembly resolutions. $^{136}$

\footnotetext{
${ }^{133}$ Sornarajah, supra note 68 , at 54 .

${ }^{134} \mathrm{~T}$ Waelde, 'Requiem for New International Economic Order', in G Hafner et al (eds.), Liber Amicorum I. Seidl-Hohenveldern (1998), 774.

Such rhetoric can still be heard in certain academic and political circles, particularly in Latin America.

${ }^{135}$ See Hartwig, supra note 132, at 663.

${ }^{136}$ See Comeaux and Kinsella, supra note 2, at 65 .

See, in general, Brower, supra note 131.
} 
The first of these attempts was Resolution 523 (VI) of 1952. Although there was no express mention of the issue of expropriation, it emphasised that "underdeveloped countries have the right to determine freely the use of their natural resources". ${ }^{137}$ That year, the General Assembly expressly declared in Resolution 626 (VII) that "the right of peoples freely to use and exploit their natural wealth and resources is inherent in their sovereignty and is in accordance with the Purposes and Principles of the Charter of the United Nations". ${ }^{138}$ Two years later, based on the right of self-determination, the permanent sovereignty over natural wealth and resources was established by Resolution 837 (IX). ${ }^{139}$

In 1958 , the General Assembly established by Resolution $1314(\mathrm{XIII})^{140}$ the Commission on Permanent Sovereignty over Natural Resources. Following its report, Resolution 1803 (XVII) was adopted in $1962 .{ }^{141}$ Known as the Resolution on Permanent Sovereignty over Natural Resources, the General Assembly declared in it the inalienable right of all states to freely dispose their natural wealth and resources in accordance with their national interests. This right was linked to the principles of sovereign equality of states, self-determination and economic independence. Resolution 1803 (XVII) of 1962 further recognised some of the requirements of a lawful taking advanced by capital-exporting states, but in a weaker form:

Nationalization, expropriation or requisitioning shall be based on grounds or reasons of public utility, security or the national interest which are recognized as overriding purely individual or private interests, both domestic and foreign. In such cases the owner shall be paid appropriate compensation, in accordance with the rules in force

\footnotetext{
${ }^{137}$ See UNGA Res. 523 (VI), adopted on 12 January, 1952.

UN General Assembly resolutions are available at $<$ http://www.un.org/documents/resga.htm $>$ (last visited 31 March, 2008).

${ }_{138}^{138}$ See UNGA Res. 626 (VII), adopted on 21 December, 1952.

${ }^{139}$ See UNGA Res. 837 (IX), adopted on 14 December, 1954.

${ }^{140}$ Adopted on 12 December that year.

${ }^{141}$ Before this resolution, the General Assembly had recommended the respect of the sovereign right of every state to dispose of its wealth and its natural resources, in conformity with the rights and duties of States under international law, in Res. 1515 (XV), adopted on 15 December, 1960.
} 
in the State taking such measures in the exercise of its sovereignty and in accordance with international law. In any case where the question of compensation gives rise to a controversy, the national jurisdiction of the State taking such measures shall be exhausted. However, upon agreement by sovereign States and other parties concerned, settlement of the dispute should be made through arbitration or international adjudication. ${ }^{142}$

Besides the international minimum standard, this resolution reaffirmed the principle of pacta sunt servanda by stating that "[f]oreign investment agreements freely entered into by or between sovereign states shall be observed in good faith $[\ldots] "{ }^{143}$

Resolution 1803 (XVII) of 1962 was adopted by 87 votes to 2, with 12 abstentions. France and South Africa voted no, and the communist-bloc, plus Ghana and Burma, abstained. The USA voted in favour, but stated -for the record- that according to Resolution 1803 (XVII) "the owner shall be paid" meant that the payment of compensation was not discretionary but an obligation of the state, and that "appropriate compensation" would be interpreted as meaning, under international law, prompt, adequate and effective compensation. ${ }^{144}$ This resolution recognises the power of the state to take private property, a principle already mentioned by Grotius, known today as the state's right to expropriate or nationalise. ${ }^{145}$ It also recognises the rule of pacta sunt servanda, dating back to Cicero and Ulpian, as applied to investment agreements. ${ }^{146}$ The right to expropriate and nationalise is an attribute of sovereignty, as much as its limitation by means of the principle of pacta sunt servanda. ${ }^{147}$ Since both principles conform to the very nature of international norms founded on the notion of sovereignty, their recognition

${ }^{142}$ UNGA Res. 1803 (XVII) of 1962, para 4.

See, in general, the whole resolution adopted that year on 14 December.

${ }^{143}$ Ibid., para 8.

${ }^{144}$ See Lowenfeld, supra note 102, at 407-410.

${ }^{145}$ See F Mann, 'Outlines of a History of Expropriation', (1959) $75 L Q R$ 188, at 192.

${ }^{146}$ See M Lachs, 'Pacta Sunt Servanda', in R Bernhardt (ed.), EPIL (1997), Vol. III, at 847.

${ }^{147}$ See Beveridge, supra note 10 , at 7, 21 \& 24. 
by the resolution was easily considered to evidence customary international law. ${ }^{148}$ This was, for instance, the position adopted by Dupuy, the sole arbitrator in the Topco/Calasiatic case. $^{149}$

Due to the consensus achieved by the contending group of states in 1962, even the payment of an "appropriate" compensation was acknowledged for many years a customary status. ${ }^{150}$ Lowenfeld explains that Resolution 1803 (XVII) was fairly regarded to:

$[\ldots]$ constitute a consensus of sorts between developed and less developed countries, around four basic principles:

- that compensation must be paid in the event of taking of alien property;

- that such compensation must be paid in accordance with international law;

- that investment agreements between states and private parties have a binding effect; and

- that arbitration agreements between states and private parties have a binding effect. $^{151}$

The General Assembly addressed the issue of permanent sovereignty over natural resources again in 1966, when Resolution 2158 (XXI) recognised, in order to improve its exercise:

[...] the right of all countries, and in particular of the developing countries, to secure and increase their share in the administration of enterprises which are fully or partly operated by foreign capital and to have a greater share in the advantages and profits derived therefrom on an equitable basis, with due regard to development needs and objectives of the peoples concerned and to mutually acceptable contractual practices. $^{152}$

104 countries voted in favour of this resolution, while 6 states abstained, including the USA, who criticised its lack of clarity on the problem of

\footnotetext{
${ }^{148}$ See, in general, Pellonpää and Fitzmaurice, supra note 8, note 30 at 61 ; Mouri, supra note 10 , note 197 at 65 \& 359-62; Comeaux and Kinsella, supra note 3, at 68; Dinstein, supra note 8, at 851; Brownlie, supra note 15, at 519; and Carreau and Juillard, supra note 125, at 404.

${ }_{149}$ Texas Overseas Petroleum Co. \& California Asiatic Oil Co. (Topco/Calasiatic) case, supra note 120, paras. 86-7.

${ }^{150}$ See, e.g., Dugard, supra note 10, at 228.

${ }^{151}$ Lowenfeld, supra note 102, at 410.

${ }^{152}$ UNGA Res. 2158 (XXI) of 1966, para. 5. See, in general, the whole resolution adopted that year on 25 November.
} 
expropriation. $^{153}$ That same year, the right of permanent sovereignty over natural resources was included in Article 1 paragraph 2 of the International Covenant on Economic, Social and Cultural Rights. ${ }^{154}$ After reaffirming this right in Resolutions 2386 (XXIII) of $1968^{155}, 2692$ (XXV) of $1970^{156}$, and 3016 (XXVII) of $1972^{157}$, the

General Assembly went a step further in 1973, when its Resolution 3171 (XXVIII)

plainly stated an exclusive national treatment standard in the following terms:

[...] the application of the principle of nationalization carried out by States, as an expression of their sovereignty in order to safeguard their natural resources, implies that each State is entitled to determine the amount of possible compensation and the mode of payment, and that any disputes which might arise should be settled in accordance with the national legislation of each State carrying out such measures. ${ }^{158}$

This declaration was founded on the principles of self-determination and sovereign equality of states, as recognised in Resolution 2625 (XXV) of 1970, which contains the Declaration on Principles of International Law concerning Friendly Relations and Co-operation among States in accordance with the Charter of the United Nations. ${ }^{159}$ The replacement of an "appropriate" compensation, for only a "possible" one, and the fact that its determination was left solely to the domestic legislation of the expropriating state, led to the adoption of Resolution 3171 (XXVIII) of 1973 by 108 votes in favour to 1 , with 16 abstentions, including this time 10 Western European countries and the USA. ${ }^{160}$ These abstentions certainly

\footnotetext{
${ }^{153}$ Lowenfeld, supra note 102 , at 411 .

${ }^{154}$ Art. 1 para. 2 of this treaty provides that:

All peoples may, for their own ends, freely dispose of their natural wealth and resources without prejudice to any obligations arising out of international economic co-operation, based upon the principle of mutual benefit, and international law. [...]

UNGA Res. 2200A (XXI) of 1966, adopted on 16 December.

The International Covenant on Economic, Social and Cultural Rights entered into force in 1976.

${ }^{155}$ UNGA Res. 2386 (XXIII) of 1968, adopted on 19 November.

${ }^{156}$ UNGA Res. 2692 (XXV) of 1970, adopted on 11 December.

${ }^{157}$ UNGA Res. 3016 (XXVII) of 1972, adopted on 18 December.

${ }^{158}$ UNGA Res. 3171 (XXVIII) of 1973, para. 3. See, in general, the whole resolution adopted that year on 17 December.

${ }_{159}$ See, in general, UNGA Res. 2625 (XXV) of 1970, adopted on 24 October.

${ }^{160}$ Lowenfeld, supra note 102 , at 412.
} 
reduced the legal weight of this resolution. The developed countries' opposition, almost a year later, to the adoption of the so-called Charter of Economic Rights and Duties of States would confirm the lack of opinio iuris of this new approach on the issue of compensation.

\subsubsection{International economic orders}

Seeking greater sympathy for their particular interests in the international economic system, and expecting to neutralise the 1947 General Agreement on Tariffs and Trade (GATT), developing countries decidedly encouraged the creation in 1964 of the United Nations Conference on Trade and Development (UNCTAD) as their "institutionalized mouthpiece" in the field of international economic relations. ${ }^{161}$ By the beginning of the 1970 s, however, capital-importing states had given up on their intention of reforming the international economic order. The idea of its replacement by a new one strongly emerged in these years. ${ }^{162}$ The success of the Organization of the Petroleum Exporting Countries (OPEC) in substantially increasing the prices of this natural resource in 1973, served as a catalyst that brought together developing countries in support of a call for a NIEO. Communist states declared themselves immune from most of the demands that this order involved. Nevertheless, they supported the third-world, as part of their strategy of political and economic competition with Western states. ${ }^{163}$ Designed to better

\footnotetext{
${ }^{161}$ C Tomuschat, 'New International Economic Order', in R Bernhardt (ed.), EPIL (1997), Vol. III, at 579

${ }^{162} \mathrm{Ibid}$.

${ }^{163}$ Waelde, supra note 134 , at 782.
} 
was defined by Tomuschat:

as a body of general legal, political and economic principles, outlined in various resolutions and declarations of the United Nations, which, as a whole, [were] intended to provide a blueprint for an alternative international economic system, the overriding objective of which [was] an international redistribution of wealth to the advantage of developing States and to be achieved by systematic preferential treatment of this group of States on all levels of international economic relations. ${ }^{164}$

In 1974, the Sixth Special Session of the UN General Assembly adopted the

Declaration on the Establishment of the New International Economic Order.

Reaffirming once more the sovereign equality of states and self-determination, the resolution confirmed the:

[f]ull permanent sovereignty of every State over its natural resources and all economic activities. In order to safeguard these resources, each State is entitled to exercise effective control over them and their exploitation with means suitable to its own situation, including the right to nationalization or transfer of ownership to its nationals, this right being an expression of the full permanent sovereignty of the State. ${ }^{165}$

This declaration was supplemented by the Programme of Action on the Establishment of a New International Economic Order, included in UN General Assembly Resolution 3202 (S-VI) of the same year. ${ }^{166}$ Both resolutions were adopted by consensus, notwithstanding the reservations registered by developed States. ${ }^{167}$ Inspired in them, the most important document encompassing the principles of NIEO was the Charter of Economic Rights and Duties of States, adopted by the UN General Assembly Resolution 3281 (XXIX) of $1974 .^{168}$ Twelve

\footnotetext{
${ }^{164}$ Tomuschat, supra note 161 , at 578 .

${ }^{165}$ UNGA Res. 3201 (S-VI) of 1974, para. 4 (e). See, in general, the whole resolution adopted that year on 1 May.

${ }_{166}$ Adopted on 1 May, 1974.

${ }^{167}$ E Petersmann, 'Charter of Economic Rights and Duties of States', in R Bernhardt (ed.), EPIL (1992), Vol. I, at 562.

${ }^{168}$ This three 1974 resolutions - UNGA Res. 3201 (S-VI), 3202 (S-VI), and 3281 (XXIX)- have been described as "probably [...] the most important, comprehensive, far-reaching -and controversialresolutions of the General Assembly in economic matters".

Waelde, supra note 134, at 772 .
} 
years after Resolution 1803 (XVII) of 1962, and less in conformance with the position of developed countries, the General Assembly declared this time that each state has the right:

[t]o nationalize, expropriate or transfer ownership of foreign property, in which case appropriate compensation should be paid by the State adopting such measures, taking into account its relevant laws and regulations and all circumstances that the State considers pertinent. In any case where the question of compensation gives rise to a controversy, it shall be settled under the domestic law of the nationalizing State and by its tribunals, unless it is freely and mutually agreed by all States concerned that other peaceful means be sought on the basis of the sovereign equality of States and in accordance with the principle of free choice of means. ${ }^{169}$

Belgium, Denmark, the Federal Republic of Germany, Luxembourg, the UK, and the USA voted against this resolution. Austria, Canada, France, Israel, Italy, Japan, the Netherlands, Norway, and Spain abstained. ${ }^{170}$ With 120 votes in favour to 6 , and 10 abstentions, to a very large extent, this resolution confirmed the Mexican doctrine set forth in the diplomatic correspondence ensued with the US in 1938. In fact, it was no other than the president of Mexico who first suggested the idea of a legally binding Charter of Economic Rights and Duties of States. And it was this country that officially introduced in the Second Committee of the General Assembly a draft Charter that would be voted and adopted as Resolution 3281 (XXIX) in 1974. ${ }^{171}$ Again, the standard of compensation was typified as "appropriate" and its determination was left exclusively to the domestic laws of the nationalising or expropriating state. As with Resolution 3171 (XXVIII) of 1973, all the major capitalexporting states either opposed or abstained from the 1974 Charter and its national treatment standard. ${ }^{172}$ This circumstance minimised the legal impact of the Charter:

\footnotetext{
${ }^{169}$ UNGA Res. 3281 (XXIX) of 1974, art. 2.2 (c). See, in general, the whole resolution adopted that year on 12 December.

${ }^{170}$ Lowenfeld, supra note 102, at 413.

${ }^{171}$ See Petersmann, supra note 167, at 561-2.

${ }^{172} \mathrm{Ibid}$., 562, and Norton, supra note 77, at 478.
} 
its challenge to international law was limited to a political one. ${ }^{173}$ According to Petersmann, the drafting history and the voting of the resolution deprived its content of the character of opinio iuris, "at least on the part of [its] dissenters and abstainers, which included the main addressees of many of the Charter demands". ${ }^{174}$ In the Topco/Calasiatic case, Dupuy considered the Charter to have nothing more than a lege ferenda value and only for those states that adopted it. For those countries voting against it, Dupuy even concluded that this resolution was contra legem. ${ }^{175}$ Lowenfeld recalls that, in its historical context:

[a]t minimum, the Charter on the Rights and Duties of States was a concerted effort by the developing countries to repudiate a system of law in whose creation they played little or no part. [...] Viewed more than a quarter century later, the Charter [...] seems less significant than it appeared at the time. If there was indeed an effort to divorce international investment form international law, that effort did not succeed, [n]early all the capital-exporting states either voted against [it] or abstained, so that the consensus attributed to Resolution 1803 of 1962 [...] could not be attributed to the Charter. ${ }^{176}$

Against this background, the UN General Assembly abandoned the practice of advocating a NIEO in its resolutions on international economic cooperation. In some cases, it has even expressly endorsed the old or traditional economic order. ${ }^{177}$ Several reasons explain the collapse of the NIEO. According to Waelde, the concept was politically and commercially unworkable, for -in his words- "[i]t was not possible to direct or regulate international business by resolutions at diplomatic conferences". ${ }^{178}$ Third-world governments eventually realised that international trade and foreign

\footnotetext{
${ }^{173}$ See Lowenfeld, supra note 102 , at 413-4.

See, in general, Pellonpää and Fitzmaurice, supra note 8, note 30 at 61; Petersmann, supra note 167, at 562; I Seidl-Hohenveldern, 'Aliens, Property', in R Bernhardt (ed.), EPIL (1992), Vol. I, at 118; Mouri, supra note 10, at 359-62; Comeaux and Kinsella, supra note 3, at 68; Brownlie, supra note 15, at 518; and Carreau and Juillard, supra note 125, at 404 .

${ }_{174}^{17}$ Petersmann, supra note 167 , at 564.

175 Texas Overseas Petroleum Co. \& California Asiatic Oil Co. (Topco/Calasiatic) case, supra note 120 , paras. 87-8.

${ }^{176}$ Lowenfeld, supra note 102, at 413.

See, also, Dinstein, supra note 8, at 851 .

${ }^{177}$ Tomuschat, supra note 161 , at 581 .

${ }^{178}$ Waelde, supra note 134 , at 778 .
} 
investment were not responsible for underdevelopment. As a result, open marketeconomies were established in these countries, and the inward-orientation of national policies was replaced by an outward-orientation of them. ${ }^{179}$ Furthermore, the statist model of development was seriously discredited, due to corruption practices in thirdworld states, and the fall of communism or its transformation -as in China and Vietnam- left those countries supporting the NIEO without an alternative model to capitalism. In all, the very notion of a third world, with its own characteristics and interests, disappeared after the other two blocks -the first and second worlds- faded away with the end of the Cold War. ${ }^{180}$

\subsection{Changes in economy, politics and treaty-law}

The political and economical background that explained the $20^{\text {th }}$ century nationalisation process, and the ensuing debate on compensation at the General Assembly, has been essentially transformed in the last decades. ${ }^{181}$ Politically, permanent sovereignty over natural resources is no longer a priority for those states that gained control over these elements. Moreover, the favourable scenario that had given capital-importing countries a unity of purpose and, consequently, a considerable diplomatic weight, has been substantially modified by the recovery of the developed states from the 1970 s oil crisis and the collapse of communism at the end of the 1980s. Economically, foreign investment is no longer focused exclusively on the area of natural resources. Other sectors like manufacturing, services and high

\footnotetext{
${ }^{179}$ Ibid., 779-80.

${ }^{180}$ See ibid., 780-2.

${ }^{181}$ See UNCTAD, supra note 19, at 11-2.
} 
technology are increasingly attracting foreign investors today. These changes in international politics and economics had led to a withdrawal of the state from the direction of business worldwide. Deregulation and privatisation became key topics in the governmental agendas of most states, whether developed or developing. By the end of the last century, foreign investors had returned to former second and third world countries, encouraged by the liberalisation of investment conditions and economic growth. $^{182}$

The mixture of fear and desire that foreign investment represented to developing states is largely part of the past. It is no longer perceived as negative in a globalised world, based on deep and extended links between national societies. ${ }^{183}$ Property rights and market-oriented policies have been increasingly recognised. State-run enterprises have become privatised companies that need foreign investment to operate and thrive in profitable, but highly-regulated sectors of the economy. In this context, the old hesitation between restricting or facilitating foreign investment is gone, even in those states that supported the Charter of Economic Rights and Duties of States in $1974 .{ }^{184}$ It was not only the decline and fall of the Soviet Union and its satellites that made them change their mind. It was also the economic stagnation of most of Africa and Latin America, which sharply contrasted with the fast economic development of the East Asian states that had welcomed foreign investment and free-market policies, like Hong Kong, Singapore, South Korea, Taiwan, and Thailand. In the end, even those countries that did not reject foreign investors, but did not encourage them either, realised that an attractive investment

\footnotetext{
${ }^{182}$ See Waelde, supra note 134 , at 783-4.

${ }^{183}$ See Bishop, Crawford and Reisman, supra note 82, at 7-8.

${ }^{184}$ See Comeaux and Kinsella, supra note 3, at xxi-iii; and Waelde, supra note 134, at 783-5.
} 
climate was needed if they were to profit from foreign capital in their development process. $^{185}$

\subsubsection{Investment protection at the turn of a century}

Following the debt crisis of the $1980 \mathrm{~s}$, foreign direct investment (FDI) -i.e. when the manager holds control of the company ${ }^{186}$ - is now perceived as more attractive by host-states than foreign indirect or portfolio investment -this is, when the management and control of the company are dissociated. ${ }^{187}$ The main reasons for this new approach towards FDI are that it is easily available, it does not burden the capital-importing country with debt, and it brings additional contributions to the host-state, for example, in terms of know-how, technology, and skills. ${ }^{188}$ Numerous other benefits of FDI for the host country can be mentioned. Just to name a few, those highlighted by Rubins are worth recalling: "wage increases, reduced unemployment, increased demand for local goods, inflow of foreign capital, opening of markets, improved balance of payments, $[\ldots]$ increased tax revenues, and improved infrastructure". ${ }^{189}$

Developing countries, eager to regulate and attract foreign investment, have committed themselves to its encouragement and protection through national laws

\footnotetext{
${ }^{185}$ See A Lowenfeld, 'Investment Agreements and International Law', (2003) 42 Colum. JTN 123, at 126-7.

${ }^{186}$ FDI may take the form of a new venture or the acquisition of an existing one. S Riesenfeld, 'Foreign Investments', in R Bernhardt (ed.), EPIL (1995), Vol. II, at 435.

${ }^{187}$ Portfolio investment normally takes the form of a movement of money, aimed at buying shares in a foreign company or other security instruments by which capital is raised abroad for ventures. Sornarajah, supra note 3 , at 7.

${ }^{188}$ UNCTAD, supra note 19 , at 12.

189 N Rubins, 'The Notion of 'Investment' in International Investment Arbitration', in N Horn (ed.), Arbitrating Foreign Investment Disputes. Procedural and Substantive Legal Aspects (2004), note 10 at 286.
} 
enacted to deal specifically and solely with the investment of aliens in one piece of legislation. They are known as investment codes. ${ }^{190}$ Despite being the result of different social, economical and legal traditions, these codes bear extensive similarities and even uniformity on particular topics. Examples of investment codes are the Korean Foreign Capital Inducement Act of 1966; the Chilean Statute of Foreign Investment of 1974; the Namibian Foreign Investment Act of 1990; and the Polish Foreign Investment Law of $1991 .{ }^{191}$ The primary purpose of investment codes is the promotion of FDI, and to that effect they regulate its admission and standards of treatment ${ }^{192}$. These standards include national and most-favoured-nation (MFN) treatment; sometimes fair and equitable treatment (FET); the free transfer of capital and profits; the protection against expropriation; and a dispute settlement mechanism. ${ }^{193}$

Treaties dealing with the promotion and protection of foreign investment have come to confirm and supplement domestic policies and provisions favourable to it. BITs started to be signed and ratified on the second half of the $20^{\text {th }}$ century by developed and developing countries, not only to encourage foreign investment, but also to protect it. ${ }^{194}$ This second aspect of BITs explains their spread. Host-states compete to offer potential investors a credible protection of foreign property mostly by concluding BITs. These treaties allow governments to make clear commitments which explicitly involve states, not just private parties and governmental officials. A

\footnotetext{
${ }^{190} \mathrm{R}$ Buxbaum and S Riesenfeld, 'Investment Codes', in R Bernhardt (ed.), EPIL (1995), Vol. II, at 1440; and A Parra, 'Principles Governing Foreign Investment, as Reflected in National Investment Codes', (1992) 7/II ICSID Rev. 428, at 428.

${ }^{191}$ See, in general, Parra, supra note 190.

192 See P Bernardini, 'Investment Protection under Bilateral Investment Treaties and Investment Contracts', (2001) 2/II JWIT 235, at 238-9; and UNCTAD, supra note 19, at 14-6.

${ }^{193}$ See, in general, Parra, supra note 190.

${ }^{194}$ See Dolzer and Stevens, supra note 16, at 351; Redfern and Hunter, supra note 62, at 564-6; and UNCTAD, supra note 19, at 2-4, 13 \& 18-20.

See, also, Chapter 5 infra.
} 
mandatory dispute-settlement mechanism enhances the enforcement of those commitments. ${ }^{195}$ The first BIT was entered into by Germany and Pakistan in $1959 .{ }^{196}$ The number of agreements concluded worldwide since then has increased substantially. By 2006, almost 2,500 BITs had been signed, most of them after 1990 . The total number of BITs in force was more than 1,800 by the end of $2005 .{ }^{197}$ BITs have even been concluded between developing states ${ }^{198}$, and developed ones. ${ }^{199}$ At the end of 2004, one-fourth of the total number of BITs concluded worldwide corresponded to those signed between developing states. ${ }^{200}$ The only countries that have not yet concluded at least one BIT are city states or island microstates. ${ }^{201}$ Bilateral, trilateral and multilateral EIAs currently complement the international law of foreign investment. ${ }^{202}$ One example is the 1992 North American Free Trade Agreement (NAFTA) between Canada, Mexico and the US. ${ }^{203}$ Notwithstanding its

\footnotetext{
${ }^{195}$ See, in general, Z Elkins, A Guzman and B Simmons, 'Competing for Capital: The Diffusion of Bilateral Investment Treaties, 1960-2000', (2008) 1 UILR 265.

${ }^{196}$ Available at $<$ http://www.unctad.org/sections/dite/iia/docs/bits/germany_pakistan.pdf> (last visited 31 March, 2008).

197 See UNCTAD, supra note 19, at 18; UNCTAD, Developments in International Investment Agreements in 2005 (2006), 2; and UNCTAD, The Entry into Force of Bilateral Investment Treaties (2006), 2

${ }^{198}$ B Kishaiyian, 'The Utility of Bilateral Investment Treaties in the Formulation of Customary International Law', (1994) 14 Nw JILB 327, at 327; Schrijver, supra note 82, at 191; and UNCTAD, supra note 19, at 19.

See, e.g., the 1997 Argentina-Costa Rica BIT, available in Spanish at

$<$ http://www.unctad.org/sections/dite/iia/docs/bits/argentina_costarica_sp.pdf > (last visited 31 March, 2008).

${ }^{199}$ See, e.g., the 1975 Singapore-UK BIT, available at

$<$ http://www.unctad.org/sections/dite/iia/docs/bits/uk_singapor.pdf > (last visited 31 March, 2008).

${ }^{200}$ This increase reflects an emphasis in recent development strategies based on South-to-South cooperation and investment, and the emergence as global players of companies in developing countries.

UNCTAD, Recent Developments in International Investment Agreements (2005), 3-4.

${ }^{201}$ Such as Monaco or Liechtenstein, and Kiribati or St. Kitts \& Nevis.

Elkins, Guzman and Simmons, supra note 195, at 299-300.

${ }^{202}$ See Redfern and Hunter, supra note 62, at 565-6; and UNCTAD, supra note 19, at 13, \& 17-8.

See, also, Chapter 6 infra.

${ }^{203} \mathrm{See}$ Chapter 11 on Investment of NAFTA.
} 
sectorial character, the multilateral 1994 Energy Charter Treaty (ECT) also includes important investment provisions. ${ }^{204}$

There are other examples too. The Common Market of the South, commonly referred to as Mercosur, is a customs union between Argentina, Brazil, Paraguay, Uruguay, and Venezuela. The investment of aliens and related issues are addressed in its 1994 Colonia and Buenos Aires Investment Protocols. ${ }^{205}$ The Colonia Protocol covers foreign investments from nationals of member-states in the territory of any other member-state, and includes in its Article 4 a protection against expropriation which resembles that of NAFTA. Article 1 defines investment in traditional broad terms, comprising tangibles and intangibles, and Article 9 gives the investor the option of having an investment dispute with the host-state settled by arbitration under the rules of the International Centre for Settlement of Investment Disputes (ICSID), or the UN Commission on International Trade Law (UNCITRAL). The Buenos Aires Protocol covers foreign investments from nationals of non-member states in the territory of any member-state, and provides the same protections as the Colonia Protocol, including the settlement of investor-to-state disputes through international arbitration. Neither of the two Mercosur protocols is, however, in force today. ${ }^{206}$ The natural reluctance of Brazil towards the international protection of foreign investment, the numerous BIT arbitrations initiated against Argentina, and the

\footnotetext{
${ }^{204}$ See Part III and V of ECT.

${ }^{205}$ The Colonia Protocol for the Reciprocal Promotion and Protection of Investments in Mercosur was approved by Common Market Council Decision No. 11/93 of 17 January 1994. Available in Spanish at <http://www.sice.oas.org/Trade/MRCSR/colonia/pcolonia_s.asp> (last visited $31 \mathrm{March}, 2008$ ).

The Buenos Aires Protocol on the Promotion and Protection of Investments in Mercosur from NonMember Countries was approved by Common Market Council Decision No. 11/94 of 5 August 1994. Available in Spanish at:

<http://www.cancilleria.gov.ar/comercio/mercosur/normativa/decision/1994/dec1 194.html> (last visited 31 March, 2008).

206 A comparison between both instruments is available in Spanish at $<$ http://www.ftaaalca.org/ngroups/ngin/publications/spanish99/cint_mer.asp> (last visited 31 March, 2008).
} 
entrance of Venezuela as a member to the customs union in 2005, considerably reduce the chances of obtaining the necessary number of ratifications for these instruments. But this situation does not change the overall picture of international investment law, for the total number of EIAs that contain a commitment to liberalise, promote and protect foreign investment was more than 230 by $2006 .^{207}$

This impressive network of BITs and EIAs is mainly aimed at facilitating trade and investment flows. The promotion and protection of foreign investment is achieved through provisions on its admission, general standards of treatment and mechanisms for the settlement of investment disputes. ${ }^{208}$ Among these standards are, for instance, FET, full protection and security, non-discrimination, observance of specific undertakings, national and MFN treatment, and free transfer of funds. Although BITs and the corresponding chapters of EIAs do not follow a uniform design, they tend to establish the international adjudication of investor-to-state disputes and corroborate the customary requirements of a lawful expropriation with an extraordinary homogeneity. ${ }^{209}$ This circumstance, and the inclusion of a national treatment, combined with applications of the international standard, like the protection against expropriation, FET, and full protection and security, among others, has meant the demise of the Calvo doctrine in treaty-law -i.e. of an exclusive national treatment for all types of investors in the host-state.

The wide conclusion of BITs and EIAs in Latin America only came to confirm the abandonment of the NIEO, even in the region of its birth. The settlement

\footnotetext{
${ }^{207}$ UNCTAD, Developments (2006), supra note 197, at 7.

${ }^{208}$ See Comeaux and Kinsella, supra note 3, at 101-4, \& 115-25; Lowenfeld, supra note 102, at 473485; Redfern and Hunter, supra note 62, at 580-592; and UNCTAD, supra note 200, at 11-13.

${ }^{209}$ See, e.g., Chapter 10 of the 2003 Free Trade Agreement between Chile and USA, available at $<$ http://www.ustr.gov/Trade_Agreements/Bilateral/Chile_FTA/Final_Texts/Section_Index.html $>$ (last visited 31 March, 2008), in relation with ECT's Arts. 10 to 17 of Part III and Art. $2 \overline{6}$ of Part V.
} 
of investor-to-state disputes through international arbitration, as well as the Hull formula, has been included in the treaties concluded by the country of Carlos Calvo Argentina-; by the state that advanced the concept of adequate or appropriate compensation -Mexico-; and by the first country to call for a NIEO in 1952, during the debate of the draft of the International Covenant on Human Rights -Chile. ${ }^{210}$ Many Latin American states have also become a member to the Multilateral Investment Guarantee Agency (MIGA). ${ }^{211}$ More importantly, most of them have become a party to the 1965 Convention on the Settlement of Investment Disputes between States and Nationals of Other States (Washington Convention). ${ }^{212}$ Following the then predominant NIEO approach in the region, these states had stayed out of this treaty during the 1960s and the 1970s. While some Latin American countries only became parties to the Washington Convention in the 1980s, most of them did in the $1990 \mathrm{~s} .{ }^{213}$ Nevertheless, things change quickly in this volatile region. Argentina is currently the country with the highest number of investment claims lodged against it before ICSID: 42 , by November $2005 .^{214}$ The amounts awarded by arbitral panels to claimants in investment-treaty arbitrations are normally large and sometimes extremely large, particularly for a developing country like Argentina. Its government might face a hard choice: paying and mortgaging its future development,

\footnotetext{
210 See, e.g., Art. 5 and 8 of the 1990 Argentina-Italy BIT, available in Italian at $<$ http://www.unctad.org/sections/dite/iia/docs/bits/italy_argentina_it.pdf> (last visited 31 March, 2008); Arts. 5 and 11 of the 2001 Austria-Mexico BIT, available at <http://www.unctad.org/sections/dite/iia/docs/bits/austria_mexico.pdf> (last visited 31 March, 2008); and Arts. 5 and 8 of the 2003 Chile-Iceland BIT, available in Spanish at $<$ http://www.direcon.cl/documentos/ISLANDIA.pdf> (last visited 31 March, 2008).

See, also, Mouri, supra note 10, at 360.

${ }^{211}$ See Chapter 7 infra.

See, also, C Dalrymple, 'Politics and Foreign Direct Investment: The Multilateral Investment Guarantee Agency and the Calvo Clause', (1996) 29 Corn. ILJ 161.

${ }_{212}$ The Washington Convention entered into force on 14 October, 1966 and is available at $<$ http://www.worldbank.org/icsid> (last visited 31 March, 2008).

${ }^{213}$ For a list of the contracting states to the Washington Convention, see ibid.

${ }^{214}$ UNCTAD, Latest Developments in Investor-State Dispute Settlement (2005), 3.
} 
or not paying and being shunned from the powerful group of open-market, tradeoriented, pro-investment states. If forced into this choice, the Argentinian authorities have already showed their reluctance to follow the second path. The recent withdrawal of Venezuela from the World Bank, and of Bolivia from the Washington Convention, leaves open the question of whether this growing opposition to the international minimum standard will affect what, until recently, appeared to be a clear trend towards foreign investment and free-market rules not only in Latin America, but also in the other regions of the globe.

\subsubsection{A shift in the international debate}

The new economic, political and legal framework of the last decades has not modified the fact that takings are the main risk a foreign investor can face in the host country. Nonetheless, the debate on the international law of expropriation has moved from the problem of compensation to that of indirect takings. In recent years, international treaties have endorsed the notion of permanent sovereignty over natural resources and nationalisation advanced by capital-importing countries in the $20^{\text {th }}$ century; returned to the Hull formula or similar ones supported by capital-exporting countries since the $19^{\text {th }}$ century; consistently included the notion of indirect taking without defining it; and confirmed the general failure of the NIEO with regards to international investment law. ${ }^{215}$

The customary nature of the rights of permanent sovereignty over natural resources and nationalisation can be traced back to the UN General Assembly

\footnotetext{
${ }^{215}$ See Chapters 5 \& 6 infra.
} 
Resolution 1803 (XVII) of 1962. It has now been confirmed by the expropriation provisions of BITs and some EIAs, which include nationalisations as another form of taking, thus implicitly recognising the permanent sovereignty over natural resources advocated by communist, Latin American and newly decolonised countries. ${ }^{216}$ Article 13 of the 1978 Vienna Convention on State Succession in Respect of Treaties, in force since 1996, also refers expressly to the "permanent sovereignty over natural wealth and resources". ${ }^{217}$ In the area of energy law, the ECT also includes an express recognition of this right in its Article 18, titled "Sovereignty over Energy Resources". In recent years, the permanent sovereignty over natural resources has been interpreted and applied as a source of duties, as well as rights, with respect to the treatment of foreign investors. ${ }^{218}$ According to Schrijver, this means that:

Assertions of economic sovereignty of host States now include recognitions of obligations, for example to respect international law, to observe in good faith contractual and treaty obligations and to provide fair treatment to foreign investors, including appeal possibilities and recourse to international dispute-settlement mechanisms $[\ldots] .{ }^{219}$

On the specific problem of compensation, international treaties typically refer to a "prompt, adequate and effective" compensation ${ }^{220}$ or to other formulas, such as "just" compensation, followed by requirements -for example, a specific method of

\footnotetext{
${ }^{216}$ See, e.g., Art. 5 of the 1993 Algeria-France BIT, available in French at $<$ http://www.unctad.org/sections/dite/iia/docs/bits/france_algeria_fr.pdf $>$ (last visited 31 March, 2008);

and Art. 1110 of NAFTA, available at

$<$ http://www.nafta-sec-alena.org/DefaultSite/index_e.aspx?DetailID=78> (last visited 31 March, 2008).

${ }^{217}$ Available at $<$ http://untreaty.un.org/ilc/texts/instruments/english/conventions/3_2_1978.pdf > (last visited 31 March, 2008).

${ }^{218}$ Schrijver, supra note 82, at 171.

${ }^{219}$ Ibid., 251.

${ }^{220}$ E.g., Art. 8 of the 1997 Armenia-Canada BIT, available at

$<$ http://www.unctad.org/sections/dite/iia/docs/bits/canada_armenia.pdf > (last visited 31 March, 2008); and Art. 13 of the ECT, available at

$<$ http://www.encharter.org/fileadmin/user_upload/document/EN.pdf> (last visited 31 March, 2008).
} 
valuation- that make them similar in practice to the former. ${ }^{221}$ The conventional adoption of the capital-exporting countries' view on this issue indicates a deflection from the appropriate compensation standard and a return to the Hull or comparable formulas, so stubbornly rejected by capital-importing states in the diplomatic forum. $^{222}$ This is noteworthy, considering that the payment of an appropriate compensation in conformance with international law was regarded as an international legal custom, applicable in case of expropriation or nationalisation, after the adoption by the General Assembly in 1962 of Resolution 1803 (XVII).

Until the recent nationalisation wave in certain Latin American countries, including Bolivia, Ecuador and Venezuela, the last major expropriation of a general kind took place in Libya, in 1973. This concept still haunts from time to time the political debate not only in developing countries, but even in developed ones, like the UK. Although nationalisation is, under certain conditions, a legal option of the state, it is no longer the central issue in international law of expropriation. Takings are currently more likely to be aimed at individual properties or enterprises, and to assume a more subtle character: an indirect form. Guzman mentions, among the reasons for the fall of the use of outright seizures as a policy tool:

the success of [least developed countries (LDCs)] in removing control of property from the hands of former colonial powers and their citizens, a fall in the popularity of state ownership, a desire to attract new investment, a belief among LDCs that they can benefit from investment as long as it is regulated, improvement in the managerial and administrative expertise of LDC governments, changed international economic conditions, and changed behavior [sic] on the part of investors who have adopted investment strategies that are less vulnerable (e.g., joint ventures, structures that leave certain important operations outside of the host country, strategically

\footnotetext{
${ }^{221}$ See Dolzer and Stevens, supra note 16, at 108-9 \& 114-7; Sacerdoti, supra note 8, at 394-5; and UNCTAD, supra note 19 , at $235 \& 243-5$.

See, e.g., Art. 5 of the 1980 Philippines-UK BIT, available at $<$ http://www.unctad.org/sections/dite/iia/docs/bits/uk_philippines.pdf> (last visited 31 March, 2008).

${ }^{222}$ Lowenfeld, supra note 102 , at $483-4$.
} 
placed management from the home country without whom the value of assets fall substantially, and so on). ${ }^{223}$

Two categories of costs face a country that chooses to directly expropriate a foreign investor. Not only the government may be far less competent to run the enterprise than the original owner, but the country's international reputation will be damaged before other states and potential investors. ${ }^{224}$ Gutbrod and Hindelang agree with Guzman, and add that:

States which wish to import capital do not like to be associated with posing a permanent, non-calculable threat to foreign-owned property but prefer to present themselves as places with very stable, reliable and orderly regulatory environments. ${ }^{225}$

In this new context, the establishment of the boundaries between noncompensable regulatory measures and indirect takings is the main question that the international law of expropriation has to answer these days. ${ }^{226}$ Heiskanen, quoting Dolzer, describes the new scenario as follows:

the focus of debate in international investment law has shifted from the standard of compensation to the definition of expropriation. As a result of this shift, which has taken place in the context of the ongoing economic globalization and the global adoption of neo-liberal policies, the key issue in the field is no longer whether full or only 'appropriate' compensation should be paid, but rather whether any expropriation has occurred in the first place. As the State increasingly withdraws from its role as an economic actor-owner or manager of enterprises- to the role of a regulator, the tools it employs also change. In this new context, where nationalizations of enterprises or entire industries become less common, if not extinct, and are replaced by regulatory interventions, 'the single most important development in state practice has become the issue of indirect expropriations'. ${ }^{227}$

The need to answer the threshold question is compounded by the fact that unlike nationalisation programmes, which are adopted and implemented under

\footnotetext{
${ }^{223}$ A Guzman, 'Why LDCs Sign Treaties that Hurt Them: Explaining the Popularity of Bilateral Investment Treaties', (1998) 38 Virginia JIL 639, note 23 at 647.

${ }^{224}$ See ibid., 663-4.

${ }^{225}$ Gutbrod and Hindelang, supra note 51 , at 59.

See, also, Reisman and Sloane, supra note 41, at 118.

${ }^{226}$ See, e.g., Waelde and Kolo, supra note 8; Dolzer, supra note 60, at 64-5; Dolzer and Bloch, supra note 60 , at 155; Heiskanen (2003), supra note 60, at 176; Sornarajah, supra note 3 , at $344-5$; and UNCTAD, supra note 19, at 237.

${ }^{227}$ Heiskanen (2007), supra note 60 , at 215.
} 
exceptional circumstances, the regulation of vital areas of public interest is now part of the state's routine. ${ }^{228}$ BITs and the investment chapters of EIAs address the issue of takings by speaking not only speak of "expropriation" or "nationalisation", but also of "direct" or "indirect" 229 nationalisation or expropriation, and measures "equivalent" 230 or "tantamount"231 to these. The problem is that BITs and EIAs merely mention such concepts without defining any of them. Even though direct takings are normally easy to recognise; indirect expropriations are not. A definition is surely lacking. Or at least, reliable guidelines to help decision and policy-makers distinguish non-compensable measures from indirect expropriations.

\subsection{Conclusion}

Before 1917, expropriations were identified with individual takings. Two positions could be clearly distinguished in this period when approaching this area of international law. Acknowledging the interest of each state in the proper treatment of its nationals and their property abroad, capital-exporting countries upheld the international minimum standard and the principle of diplomatic protection. Conversely, affirming the complete and exclusive jurisdiction over persons and events in its territory, capital-importing countries endorsed the national treatment standard and the principle of territorial sovereignty represented by the Calvo doctrine. The former position eventually prevailed, due to the economic and military power of the states supporting it. At least, until the emergence in 1917 of the notion of nationalisation during the Russia revolution, and the remodelled concept of private

\footnotetext{
${ }^{228}$ Kriebaum, supra note 35 , at 718 .

${ }^{229}$ E.g., Art. 6 of the 2004 Uruguay-USA BIT, cited at note 51, supra.

${ }^{230}$ E.g., Art. 13 of the ECT, cited at note 220 , supra.

${ }^{231}$ E.g., Art 1110 of NAFTA, cited at note 216 , supra.
} 
property in the Mexican constitution of that year. The 1938 diplomatic exchange between the US and Mexico summed up the views of the opposed groups of states. The extensive nationalisation process, the subsequent conclusion of lump-sum agreements, and the General-Assembly based controversy involving well established legal concepts such as sovereignty, self-determination, equality of states, pacta sunt servanda, non-intervention and the peaceful settlement of disputes, brought further uncertainty to a handful of already erratic rules of customary international law.

Changes in the international politics and economy of the last half of the $20^{\text {th }}$ century have strongly undermined this enduring dispute between capital-exporting and capital-importing countries. Today, developing states no longer protect themselves from FDI, but compete for it, mainly by offering legal protection to those aliens investing abroad. To this effect, BITs and EIAs have been widely concluded in the last decades, in terms that only confirm the failure of an exclusive national treatment standard and the proposed NIEO. Legal customs, whether established or still debated, like the concept of nationalisation as an implied acknowledgement of the host state's right of permanent sovereignty over natural resources; the international adjudication of investor-to-state disputes; and the reception of the customary requirements for a lawful expropriation in the terms stubbornly put forward by developed countries, have been widely introduced in the provisions of these treaties.

In the domestic sphere, the liberalisation and development of national and international politics and economy, conveying the recognition of property rights and the enactment of investment codes, has also led to the expansion of the scope of state regulation. Health; planning and land use; antitrust; securities; consumer and 
environmental protection; amongst other, have joined traditional areas of public policy like taxation and labour. This situation and the conventional incorporation of the Hull and equivalent formulas, along with the undefined concepts of expropriation and nationalisation in their direct and indirect forms, has finally replaced in the international legal debate the problem of compensation for that of defining indirect takings. 


\section{INTERNATIONAL HUMAN RIGHTS LAW AND PROPERTY}

Property is a human right protected by international law since its inclusion in the 1948 Universal Declaration. Although not considered within the guaranteed rights of the 1966 International Covenants on Civil and Political Rights, and on Economic, Social and Cultural Rights, its deprivation is regulated by treaty law in Europe, the Americas and Africa. Within the three regional systems of human rights, however, it is mainly in Europe that expropriation has been analysed and studied since the early 1950s. Far from the ideological debate at the UN between capitalimporting and capital-exporting states, based on the opposition of the principles of national and international treatment of aliens, the European Commission and Court of Human Rights have developed an influential case-law on interferences with property. This case-law derives from their interpretation of Article 1 of the First Protocol of the European Convention on Human Rights.

According to Article 1, as construed by these institutions, the state is not prevented from interfering with the use of property. A measure that produces this result is justified when the correspondent authorities observe a fair balance between individual and community interests. For this purpose, the state is given a wide margin of appreciation. The European Commission and Court have recognised three related rules in this provision: lesser interferences to the peaceful enjoyment of possessions, the control on its use, and the deprivation of property. Each rule is 
found, respectively, in the first sentence of Article 1, in the second sentence of the same paragraph, and in its second paragraph. Distinguishing among these rules is not easy in practice. The European Court has given a broad interpretation to the notion of control on the use of property. Conversely, the concept of expropriation has been construed more restrictively. In this context, this tribunal will consider lesser interferences only when it is not able to establish a deprivation or control on the use. From the three forms of interference that comprise Article 1, only deprivations create a right to compensation. And only in relation with those non-nationals that were victims to an expropriatory measure. The state will enjoy a wide margin of appreciation at the moment of establishing the amount of compensation due, especially in cases of nationalisation. On this respect, the European Court requires an amount reasonably related with the property taken, but not necessarily full compensation.

This chapter deals with property and its deprivation in international human rights law. It centres on the protection of this right in the Americas, Africa, and Europe. The relevance of the decisions of the European Commission and Court explains the focus given to the practice of these institutions regarding not only the deprivation of property, but also lesser interferences and the control on its use. This case-law is addressed in detail, explaining the nuances surrounding each of the rules included in Article 1 of the First Protocol. The chapter ends with the study of the meaning given by these institutions to certain concepts included in the third rule: public interest, conditions provided by municipal law, and those stipulated by general principles of international law. 


\subsection{A debated right and its deprivation}

The right to property is part of the 1948 Universal Declaration of Human Rights. Article 17 of this declaration states that "(1) Everyone has the right to own property alone as well as in association with others", and "(2) No one shall be arbitrarily deprived of his property". ${ }^{232}$ Adopted as a UN General Assembly resolution ${ }^{233}$, the Universal Declaration was the result of a collective effort of the post-Second World War international society that included, for the first time in the history of international law, states with important differences in their political, social, economic and cultural backgrounds. According to Cassese, its aim was to find the lowest common denominator in the conception of basic human rights, and the relationship between state and individual. ${ }^{234}$ This legally non-binding instrument focused on civil and political rights, rather than on economic, social, and cultural rights. $^{235}$ Although it reflected a developed states' view of human rights, the Universal Declaration has been considered to evidence customary international law. ${ }^{236}$ It forbade arbitrary deprivations of property and, therefore, acknowledged the right to expropriate by implication. ${ }^{237}$ The two legally binding 1966 multilateral treaties known as the UN Covenants, one on civil and political rights, and the other

\footnotetext{
${ }^{232}$ Available at <http://www.un.org/rights/50/decla.htm> (last visited 31 March, 2008).

${ }^{233}$ UNGA Res. 217 (III), adopted on 10 December, 1948.

${ }^{234}$ Cassese, supra note 77 , at 299.

${ }^{235}$ Ibid.

${ }^{236}$ See F Tschofen, 'Multilateral Approaches to the Treatment of Foreign Investment', (1992) 7/II ICSID Rev. 384, at 388 .

See, also, Filartiga v. Peña-Irala, US Circuit Court of Appeals, $2^{\text {nd }}$ Circuit, 30 June, 1980, Opinion by Circuit Judge Kaufman. Available at

$<$ http://www.icrc.org/ihl-nat.nsf/0/27721 clb47e7ca90c1256d18002a2565? OpenDocument> (last visited 31 March, 2008).

${ }^{237}$ Tschofen, supra note 236 , at $407-8$.
} 
on economic, social and cultural rights, were based on the Universal Declaration. ${ }^{238}$

The Covenants, however, did not include the right of property, revealing a second and third world approach to human rights. ${ }^{239}$ This omission was in conformity with the trend to undermine international customary norms, which in the past had protected the property of aliens from expropriation through the Hull formula. ${ }^{240}$ The right to own property was only reasserted by the UN in 1986, in a General Assembly resolution. $^{241}$ Meanwhile, two regional human-rights treaties followed in the footsteps of the Universal Declaration and acknowledged the state's right of expropriation by implication in Europe and the Americas during the 1950s and 1960s. A couple of decades later, another regional human-rights treaty recognised this right in Africa.

\subsubsection{Inter-American and African approaches}

Article XXIII of the 1948 American Declaration of the Rights and Duties of Man expressly established that "[e]very person has a right to own such private property as meets the essential needs of decent living and helps to maintain the

\footnotetext{
${ }^{238}$ Ibid., 388.

The International Covenant on Civil and Political Rights and its first Optional Protocol, and the International Covenant on Economic, Social and Cultural Rights, were opened for signature, ratification and accession by UN General Assembly Res. 2200 A (XXI), adopted on 16 December, 1966.

Both treaties entered into force in 1976

${ }^{239}$ Cassese, supra note 77 , at 303 .

See A Robertson and J Merrills, Human Rights in the World (1996), 37 \& 276.

${ }^{240}$ Cassese, supra note 77, at 303.

${ }^{241}$ I Seidl-Hohenveldern, International Economic Law (1992), 132.

See UNGA Res. 41/132 of 4 December, 1986.
} 
dignity of the individual and of the home". ${ }^{242}$ Originally, the American Declaration was a legally non-binding instrument adopted within the context of the Organization of American States (OAS). It came to be considered by the Inter-American Commission on Human Rights and the Inter-American Court of Human Rights as incorporated into the OAS Charter, only after the amendment of the latter in 1967 and $1970 .^{243}$ The Inter-American Commission even considered the American Declaration in the 1990 s to establish "universal and regional rules which have become rules of customary international law and, as such $[\ldots]$ obligatory in $[\ldots]$ international law". ${ }^{244}$ By then, the Inter-American human rights system had established a more detailed regulation of the right of property in another legally binding instrument. Article 21 of the 1969 American Convention on Human Rights also known as the Pact of San José de Costa Rica ${ }^{245}$ - contains a protection against expropriation. Consequently, it recognises the correspondent right of the state to expropriate by implication, following certain requirements which constitute a minimum standard of treatment applicable not only to foreigners, but also to nationals of the state adopting the respective measure. Article 21 provides:

\footnotetext{
${ }^{242}$ The American Declaration was approved by the Ninth International Conference of American States held in Bogotá, Colombia, in 1948. Available at <http://www.hrcr.org/docs/OAS_Declaration/oasrights.html> (last visited 31 March, 2008).

${ }^{243} \mathrm{~S}$ Davidson, The Inter-American Human Rights System (1997), 23-30.

See Res. No. 23/81, Case 2141 (United States), 6 March, 1981, Annual Report of the I/A Commission HR 1980-1981, available at <http://www.cidh.org/annualrep/80.81eng/USA2141.htm> (last visited 31 March, 2008);

and Res. No. 3/87, Case 9647 (United States), 22 September, 1987, Annual Report of the I/A Commission HR 1986-1987, available at <http://www.cidh.org/annualrep/86.87eng/EUU9647.htm> (last visited 31 March, 2008).

${ }^{244}$ 'Report on Nicaragua', Annual Report of the I/A Commission HR 1993, available at $<$ http://www.cidh.org/annualrep/93eng/TOC.htm> (last visited 31 March, 2008).

See, also, S Davidson, 'The Civil and Political Rights Protected in the Inter-American Human Rights System', in D Harris and S Livingstone (eds.), The Inter-American System of Human Rights (1998), 276.

Finally, see Advisory Opinion OC-10/89 of the I/A Court HR, 14 July, 1989, on the Interpretation of the American Declaration of the Rights and Duties of Man within the Framework of Article 64 of the American Convention on Human Rights, available at $<$ http://www1.umn.edu/humanrts/iachr/b_11_4j.htm> (last visited 31 March, 2008). ${ }^{245}$ In force since 1978 .
} 
1. Everyone has the right to the use and enjoyment of his property. The law may subordinate such use and enjoyment to the interest of society.

2. No one shall be deprived of his property except upon payment of just compensation, for reasons of public utility or social interest, and in the cases and according to the forms established by law.

3. Usury and any other form of exploitation of man by man shall be prohibited by law. ${ }^{246}$

Property was one of the most debated rights during the preparatory stage of the

American Convention. Some delegations even tried to remove any reference to it from the treaty, but in the end the right to property and its social function were included in the approved text of the Convention. ${ }^{247}$ Since then, the Inter-American Commission has considered Article 21 as a rule of customary international law. ${ }^{248}$

The Inter-American Court has dealt exceptionally with this right. According to it, Article 21 refers to property in the traditional wide sense attached to the word, comprising tangible and intangible assets. ${ }^{249}$ Under this broad interpretation, the private and communal property of indigenous peoples has also been considered protected by Article 21. ${ }^{250}$ The only case presented before the Court that relates

\footnotetext{
${ }^{246}$ Available at $<$ http://www.cidh.org/Basicos/English/Basic3.American\%20Convention.htm> (last visited 31 March, 2008).

${ }^{247}$ See Comunidad Mayagna (Sumo) Awas Tingni v. Nicaragua, I/A Court HR, Series C No. 79 , Judgment, 31 August 2001, para. 145 \& note 57. Available in Spanish at <http://www.corteidh.or.cr/docs/casos/articulos/Seriec_79_esp.pdf> (last visited 31 March, 2008).

${ }^{248}$ Davidson, supra note 244, at 276.

See 'Report on Nicaragua', Annual Report of the I/A Commission HR 1993, supra note 244.

${ }^{249}$ See Baruch Ivcher Bronstein v. Perú, I/A Court HR, Series C No. 74, Judgment, 6 February 2001, paras, 122. Available in Spanish at

<http://www.corteidh.or.cr/docs/casos/articulos/Seriec_74_esp.pdf> (last visited 31 March, 2008).

See, also, Comunidad Mayagna (Sumo) Awas Tingni case, supra note 247, para. 144; Cinco

Pensionistas v Perú, I/A Court HR, Series C No. 98, Judgment, 28 February 2003, para. 103, available in Spanish at $<\mathrm{http}: / / \mathrm{www}$.corteidh.or.cr/docs/casos/articulos/Seriec_98_esp.pdf $>$ (last visited 31 March, 2008);

Comunidad Indigena Yakye Axa v. Paraguay, I/A Court HR, Series C No. 125, Judgment, 17 June 2005 , para. 137, available in Spanish at

<http://www.corteidh.or.cr/docs/casos/articulos/seriec_125_esp.pdf> (last visited 31 March, 2008); and Comunidad Indigena Sawhoyamaxa v. Paraguay, I/A Court HR, Series C No. 146, Judgment, 29 March 2006, para. 121, available in Spanish at $<\mathrm{http}: / /$ www.corteidh.or.cr/docs/casos/articulos/seriec_146_esp2.pdf> (last visited 31 March, 2008).

${ }^{250}$ See Comunidad Mayagna (Sumo) Awas Tingni case, supra note, paras. 148-9 \& 151; Comunidad Indigena Yakye Axa case, supra note 249, paras. 135-7; and Comunidad Indigena Sawhoyamaxa case, supra note 249 , paras. 118-21.
} 
directly, so far, to an indirect taking is Ivcher. The applicant was a naturalised Peruvian citizen who owned a television network where he had been denouncing serious violations of human rights and acts of corruption. In conformity to a domestic statute, owners of telecommunications media companies in Perú must be of this nationality. Based on this norm, the Peruvian state annulled Mr. Ivcher's nationality in order to remove him from the editorial control of his television network. As a consequence, a judicial resolution suspended the exercise of the applicant's rights in the company and revoked his appointment as a director and chairman. Mr. Ivcher was prevented from transferring his shares and receiving dividends, and from taking part in board meetings, where the minority shareholders took important decisions, like increasing the company's capital. This judicial measure even prevented $\mathrm{Mr}$ Ivcher's wife, co-owner of the shares, from enforcing her rights. ${ }^{251}$ The case was submitted to the Inter-American Court by the Commission, following the two-tier procedure established in the Convention. Implicitly endorsing the concept of indirect expropriation, and quoting the case-law of the European Court of Human Rights, the Court said:

To determine whether Mr. Ivcher was deprived of his property, the Court should not restrict itself to evaluating whether a formal dispossession or expropriation took place, but should look beyond mere appearances and establish the real situation behind the situation that was denounced. ${ }^{252}$

The tribunal found no evidence of public utility or social interest in the domestic judicial decision that prevented Mr. Ivcher from exercising his property rights. Moreover, the tribunal found no indication that the applicant received

On the relation between private property and the communal property of indigenous peoples, see Comunidad Indigena Yakye Axa case, supra note 249, paras. 143-51; and Comunidad Indigena Sawhoyamaxa case, supra note 249, paras. 126-41.

${ }_{251}^{25}$ See Baruch Ivcher Bronstein case, supra note 249, paras, 125-7.

${ }^{252}$ Ibid., para, 124.

The Inter-American Court made reference to Belvedere Albergheria S.R.L. v. Italy, Eur. Court HR, Reports of Judgments and Decisions 2000-VI, Judgment, 30 May 2000, para. 53. 
compensation for the deprivation of the enjoyment and use of his property, or that the measure that affected him was adopted satisfying the minimum requirements of due process of law. ${ }^{253} \mathrm{Mr}$. Ivcher's deprivation of property was thus considered inappropriate, arbitrary and in breach of Article 21 of the American Convention. ${ }^{254}$ In the words of Orrego:

It was $[\ldots]$ held that although the claimant was not deprived of his property of company shares, he was in fact deprived by judicial decision of the fundamental rights associated with such property, namely the right to vote in the company and to receive dividends. ${ }^{255}$

Article 14 of the 1981 African Charter on Human and Peoples' Rights also establishes the right of expropriation by implication. ${ }^{256}$ The terms of this provision are broad. In conformity with it, not only "[t]he right to property shall be guaranteed", but also "[i]t may only be encroached upon in the interest of public need or in the general interest of the community and in accordance with the provisions of appropriate laws" ${ }^{257}$ Like Article 1 of the First Optional Protocol to the European Convention, and contrary to Article 21 of the American Convention, Article 14 does not refer explicitly to the payment of compensation in any form. The few pronouncements of the African Commission on Human and Peoples' Rights regarding this provision relate with the state's sealing up of premises of publications. ${ }^{258}$ In Media Rights Agenda, the African Commission found a violation to the right protected by Article 14 in these terms:

\footnotetext{
${ }^{253}$ Baruch Ivcher Bronstein case, supra note 249, para, 130.

${ }^{254}$ Ibid., paras, 130-1.

${ }^{255}$ Orrego Vicuña, supra note 62, at 22.

256 This treaty is in force since 1986.

257 Art. 14 of the African Charter on Human and Peoples' Rights is available at $<$ http://wwwl.umn.edu/humanrts/instree/zl afchar.htm> (last visited 31 March, 2008).

${ }^{258}$ See C Heyns, 'Civil and Political Rights in the African Charter', in M Evans and R Murray (eds.), The African Charter on Human Rights and Peoples': the System in Practice, 1986-2000 (2002), 1745.
} 
The right of property necessarily includes a right to have access to property of one's own and the right that one's property not be removed. The decrees which enabled these premises to be sealed up and for publications to be seized cannot be said to be 'appropriate' or in the interest of the public or the community in general. [...] In addition, the seizure of the magazines for reasons that have not been shown to be in the public need or interest also violates the right to property. ${ }^{259}$

This view was reaffirmed in Constitutional Rights Project, where the African

Commission declared:

The government did not offer any explanation for the sealing up of the premises of many publications, but maintained the seizure in violation of direct court orders. [...] The right to property necessarily includes a right to have access to one's property and the right not to have one's property invaded or encroached upon. The Decrees which permitted the newspapers' premises to be sealed up and publications to be seized cannot be said to be 'appropriate' or in the interest of the public or the community in general. The Commission finds a violation of Article $14 .^{260}$

\subsubsection{The European Convention and property}

The Council of Europe advanced in 1950 the Convention for the Protection of Human Rights and Fundamental Freedoms. ${ }^{261}$ Its aim was, to encourage a cohesive democratic bloc of states that would serve as a buttress against communism and the resurgence of national-socialism. ${ }^{262}$ Better known as the European Convention on Human Rights, this international agreement had to reflect the views of the members of the Council, which ranged from capitalist to socialist states. For this purpose, its drafters tried to include those core values that create and maintain a democratic

\footnotetext{
${ }^{259}$ Communications 105/93, 128/94, 130/94 and 152/96, Media Rights Agenda and Constitutional Rights Project v. Nigeria, African Commission HPR, $12^{\text {th }}$ Activity Report 1998-99, Annex V, para. 77, in R Murray and M Evans (ed), Documents of the African Commission on Human and Peoples' Rights (2001), at 727.

${ }_{260}$ Communications 140/94, 141/94 and 145/95, Constitutional Rights Project, Civil Liberties Organisation and Media Rights Agenda v. Nigeria, African Commission HPR, $13^{\text {th }}$ Activity Report 1999-2000, Annex V, para. 54, as quoted in Evans and Murray, supra note 259, at 175.

${ }^{261}$ This treaty entered into force in 1953.

${ }^{262} \mathrm{H}$ Mountfield, 'Regulatory Expropriations in Europe: The Approach of the European Court of Human Rights', (2003) 11 NYU ELJ 136, at 138.
} 
society, while at the same time respecting the political, social and economic differences of the parties, present at the moment of its signature. ${ }^{263}$ Based on Article 17 of the Universal Declaration, the earliest list of basic civil and political rights considered by the first drafting committee of the European Convention did include the right of property, but it was later deleted on the suggestion that this right was not a fundamental requirement of a democratic society. ${ }^{264}$ According to Robertson and Merrills, it was then clear that the inclusion of the right of property would only be acceptable to Western socialist governments if the relevant provision would not prevent states from nationalising private property. ${ }^{265}$ The Council decided not to defer the signature of the European Convention until an agreement on an acceptable wording for this right and those of education and to free elections would be reached. ${ }^{266}$ The right of property was, therefore, not included in the adopted text of this treaty. Two years later, an agreement on the wording of the protection of property was reached. Incorporated in Article 1 of the First Optional Protocol to the European Convention, it said:

Every natural or legal person is entitled to the peaceful enjoyment of his possessions. No one shall be deprived of his possessions except in the public interest and subject to the conditions provided for by law and by the general principles of international law.

The preceding provisions shall not, however, in any way impair the right of a State to enforce such laws as it deems necessary to control the use of property in accordance with the general interest or to secure the payment of taxes or other contributions or penalties. ${ }^{267}$

\footnotetext{
${ }^{263}$ See ibid., 138-9.

${ }^{264}$ See D Harris, M O'Boyle and C. Warbrick, Law of the European Convention on Human Rights (1995), 516; and J Merrills and A Robertson, Human Rights in Europe. A Study of the European Convention on Human Rights (2001), 7-9.

${ }^{265}$ See Merrills and Robertson, supra note 264, at 12.

${ }^{266}$ See ibid., 12-3.

${ }^{267}$ Signed in 1952, the First Protocol came into force in 1954. The European Convention and all its protocols are available at <http://www.echr.coe.int/NR/rdonlyres/D5CC24A7-DC13-4318-B4575C9014916D7A/0/EnglishAnglais.pdf> (last visited 31 March, 2008).
} 
The right of property has been dubbed the problem child of the European family of rights and freedoms. ${ }^{268}$ The difficulties that surrounded its introduction among those protected by the European Convention explain the fact that Article 1 neither mentions expropriation as such, nor includes the right to be compensated in an express form. This right is only implied in the reference to general principles of international law regarding deprivations of property, a formula adopted as a compromise between those states in favour of mentioning compensation and those against it. $^{269}$

Article 1 was soon criticised in doctrine as an inadequate and excessively weak provision, establishing an economic and social entitlement rather than a proper right. ${ }^{270}$ The European Court of Human Rights has not shared this vision. According to it, by recognising the right to the peaceful enjoyment of possessions, Article 1 is in substance guaranteeing the right of property of both tangible and intangible assets. The wording of the other official version of the European Convention confirms the conclusion of the Court. In the French text, the first paragraph of Article 1 talks about "biens" and "propiéte", instead of "possessions". 271 The European Court, however, has not considered the right to acquire property as protected by the Convention. ${ }^{272}$ In this context, the European Commission and Court have interpreted

\footnotetext{
${ }^{268}$ D Anderson, 'Compensation for Interference with Property', (1999) 4/VI Eur. HRLR 543, at 545.

${ }^{269}$ H Ruiz Fabri, 'The Approach Taken by the European Court of Human Rights to the Assessment of Compensation for "Regulatory Expropriations" of the Property of Foreign Investors', (2003) 11 NYU $E L J 148$, at 151.

${ }^{270}$ Mountfield (2003), 139-40.

See Anderson, supra note 268, at 545; and R Clayton and H Tomlinson, The Law of Human Rights (2000), 1302.

${ }^{271}$ See G Gretton, 'The Protection of Property Rights', in A Boyle et al (eds.), Human Rights and Scots Law (2002), 276-7.

${ }^{272}$ See Marckx v. Belguim, Eur. Court HR, Series A No. 31, Judgment, 13 June 1979, para. 63.
} 
possessions to comprise, for instance, contractual rights ${ }^{273}$, company shares ${ }^{274}$, goodwill in a business ${ }^{275}$, fishing rights $^{276}$, patents $^{277}$, and planning permissions. ${ }^{278}$ According to Condorelli, neither the Commission nor the Court have identified with precision the contours of the right of property, thus allowing the progressive enlargement of this legal concept according to the needs of an evolving society. ${ }^{279}$ But such approach is not without limits. The European Court, for example, has considered the enjoyment of aesthetic or environmental qualities of possessions as not guaranteed under Article $1 .^{280}$

The meaning given by the European Court to the term possessions is an autonomous one. ${ }^{281}$ As a consequence, the determination of its existence in a specific situation is not affected by the non-recognition of an interest as a right or its legal qualification, when recognised, under the relevant municipal law. ${ }^{282}$ Nevertheless,

\footnotetext{
${ }^{273}$ See A, B and Company AS v. Federal Republic of Germany, Eur. Commission HR, No. 7742/76, (1978) 14 Decisions and Reports 146.

${ }^{274}$ See Bramelid \& Malmstrom v. Sweden, Eur. Commission HR, Nos. 8588/79 and 8589/79, (1982) 29 Decisions and Reports 64.

${ }^{275}$ See Van Marle and others $v$ Netherlands, Eur. Court HR, Series A No. 101, Judgment, 26 June 1986.

All judgments of the European Court are available at

$<$ http://www.echr.coe.int/ECHR/EN/Header/Case-Law/HUDOC/HUDOC+database/> (last visited 31 MAcrh, 2008).

${ }^{276}$ See Baner v. Sweden, Eur. Commission HR, No. 11763/85, (1989) 60 Decisions and Reports 128.

277 See Smith Kline and French Laboratories Ltd v Netherlands, Eur. Commission HR, (1990) 66 Decisions and Reports 70.

${ }^{278}$ See Pine Valley Developments Ltd and others v. Ireland, Eur. Court HR, Series A No. 222, Judgment, 29 November 1991.

See, in general, Harris, O'Boyle and Warbrick, supra note 264, at 517-9; Clayton and Tomlinson, supra note 270, at 1305-7; and C Ovey and R White, Jacobs and White, The European Convention on Human Rights (2006), 349-58.

${ }^{279}$ L Condorelli, 'Premier Protocole Additionel. Article 1', in L Pettiti, E Decaux and P Imbert (eds.), La Convention Europeénne des Droits de l'Homme (1999), 975.

${ }^{280}$ Clayton and Tomlinson, supra note 270, at 1307.
}

See, also, P Van Dijk and G Van Hoof, Theory and Practice of the European Convention on Human Rights (1998), 620.

${ }^{281}$ Gasus Dosier- und Fordertechnik GmbH v. Netherlands, Eur. Court HR, Series A No. 306-B, Judgment, 23 February 1995, para. 53.

See, also, Broniowski v. Poland, Eur. Court HR, Reports of Judgments and Decisions 2004-V, Judgment, 22 June, 2004, para. 129.

${ }^{282}$ See Harris, O'Boyle and Warbrick, supra note 264, at 517; Van Dijk and Van Hoof, supra note 280, at 619-20; Clayton and Tomlinson, supra note 270, at 1304; and Fabri, supra note 269, at 153. 
the correspondent applicant must demonstrate that his interest has an economic value. That is to say, in the words of Clayton and Tomlinson, a legal right to some benefit, even if is contingent upon satisfaction of certain conditions. ${ }^{283}$ Expectations are generally not regarded as possessions because they lack the necessary degree of certainty or concreteness. ${ }^{284}$ Exceptionally, the European Court has considered them within this concept. Licences to serve alcoholic beverages ${ }^{285}$ or to extract gravel $^{286}$, among others, are included in this term only if the licence-holder has a reasonable and legitimate expectation as to their lasting nature. ${ }^{287}$ From this perspective, claims can also be considered possessions. ${ }^{288}$ This is how the European Court construed in Pressos Compania Naviera, for instance, the legitimate expectation that an unresolved claim will be decided in accordance with the general law. ${ }^{289}$ In sum, as the European Court observed in Kopecky:

'Possessions' can be either 'existing possessions' or assets, including claims, in respect of which the applicant can argue that he or she has at least a 'legitimate expectation' of obtaining effective enjoyment of a property right. By way of contrast, the hope of recognition of a property right which it has been impossible to exercise effectively cannot be considered a 'possession' within the meaning of Article 1 of Protocol No. 1, nor can a conditional claim which lapses as a result of the nonfulfilment of the condition ${ }^{290}$.

\footnotetext{
${ }^{283}$ Clayton and Tomlinson, supra note 270 , at 1305 .

${ }^{284}$ Harris, O'Boyle and Warbrick, supra note 264, at 517.

${ }_{285}$ See Tre Traktorer Aktiebolag v. Sweden, Eur. Court HR, Series A No. 159, Judgment, 7 July 1989.

${ }^{286}$ See Fredin v. Sweden, Eur. Court HR, Series A No. 192, Judgment, 18 February 1991.

${ }^{287}$ Clayton and Tomlinson, supra note 270 , at 1305.

${ }^{288}$ See, e.g., Stran Greek Refineries and Stratis Andreadis v. Greece, Eur. Court HR, Series A No. 301-B, Judgment, 9 December 1994, para. 62; Gratzinger and Gratzingerova v. Czech Republic, Eur. Court HR, Grand Chamber, Admissibility decision, 10 July, 2002, para. 69. Available at $<\mathrm{http}: / /$ vlex.com/vid/26838945> (last visited 31 MAcrh, 2008); and Stretch v. United Kingdom, Eur. Court HR, Judgment, 24 June 2003, para. 32.

${ }^{289}$ See Pressos Compania Naviera S.A. and others v. Belgium, European Court, Series A No. 332 , Judgment, 20 November 1995.

See, also, Anderson, supra note 268, at 546.

${ }^{290}$ Kopecky v. Slovakia, Eur. Court HR, Reports of Judgments and Decisions 2004-IX, Judgment, 28 September 2004, para. 35 .

On legitimate expectations and the European Court, see, in general, Kriebaum, supra note 35, note 65 at 734 .
} 
It took some time before the first case on Article 1 was decided by the European Court. ${ }^{291}$ The increasingly complex regulations, derived from the marketoriented policies favoured in the continent during the last decades, and the establishment of the individual right of petition before the Court by Protocol 11 of the European Convention ${ }^{292}$, prompted a large and authoritative case-law on Article 1. ${ }^{293}$ State measures can interfere with the peaceful enjoyment of possessions in three different degrees under this provision. Lesser interferences, deprivations, and controls on the use of property have been identified by the European Court of Human Rights as distinct, but somehow connected rules. ${ }^{294}$ The second and third rules -this is, deprivations and controls on its use- are particular instances of the first rule -i.e. of lesser interferences with possessions. ${ }^{295}$ The fact that these rules are related explains the general approach of the European Court when considering cases under Article 1. The tribunal will first establish whether a deprivation or a control on the use of property has taken place: in both cases there has to be a reasonable and

${ }^{291}$ See Handyside v. United Kingdom, Eur. Court HR, Series A No. 24, Judgment, 7 December 1976.

${ }^{292}$ In force since 1998.

${ }^{293}$ See Gretton, supra note 271, at 291.

${ }^{294}$ This test was first applied by the European Court in 1982. See Sporrong and Lönnroth v. Sweden, Eur. Court HR, Series A No. 52, Judgment, 23 September 1982, para. 61.

See, also, Holy Monasteries v. Greece, Eur. Court HR, Series A No. 301-A, Judgment, 9 December 1994, para. 56; Carbonara and Ventura v. Italy, Eur. Court HR, Reports of Judgments and Decisions 2000-VI, Judgment, 30 May, 2000, para. 58; and Jahn and others v. Germany, Eur. Court HR, Judgment, 30 June, 2005, para. 78.

See, in general, Harris, O'Boyle and Warbrick, supra note 264, at 521; Van Dijk and Van Hoof, supra note 280, at 618; Clayton and Tomlinson, supra note 270, at 1302; Merrills and Robertson, supra note 264, at 235; Ruiz Fabri, supra note 269, at 152; and Ovey and White, supra note 278, at 346.

${ }^{295}$ See, e.g., AGOSI v. United Kingdom, Eur. Court HR, Series A No. 108, Judgment, 24 October 1986, para. 48 .

See, also, James and others v. United Kingdom, Eur. Court HR, Series A No. 98, Judgment, 21 February 1986, para. 37.

These two rules cover the three main legislative powers: the taking of private property for public use, the regulation of its use and taxation.

Clayton and Tomlinson, supra note 270, at 1303. 
foreseeable national legal basis for the measure. ${ }^{296}$ Only if neither has occurred, will it study whether the state has interfered with this right in any other way. ${ }^{297}$

\subsection{The peaceful enjoyment of possessions}

Under Article 1, the state can justify interferences with the right of property "in the public interest and subject to the conditions provided for by the law and by the general principles of international law", in relation with the second rule, and "in the general interest", in relation with the third rule. It is unlikely that any particular distinction was intended between public and general interest. The European Court has not attempted to distinguish them either. ${ }^{298}$ Moreover, the tribunal has applied a single test for the three rules at the moment of establishing whether an interference is justified or not. Each will require the achievement of a fair balance between the interests of the individual and the community. In the application of the balance test, the correspondent state has consistently been given a wide margin of appreciation not only to identify the public or general interest involved, but also to assess if it prevails over that of individuals or legal entities. ${ }^{299}$ This margin is wider in cases falling under the third rule. ${ }^{300}$ The payment of compensation will generally play an

\footnotetext{
${ }^{296}$ Mountfield, supra note 262, at 141.

${ }^{297}$ See T Allen, Property and The Human Rights Act 1998 (2005), 110-2; and Ovey and White, supra note 278 , at 347 .

${ }^{298}$ Gretton, supra note 271 , at 281.

${ }^{299}$ Clayton and Tomlinson, supra note 270, at 1314.

${ }^{300}$ See Sporrong and Lönnroth case, supra note 294, para. 69.

See, also, Holy Monasteries case, supra note 294, para. 70; and Velosa Barreto v. Portugal, Eur. Court HR, Series A No. 334, Judgment, 21 November 1995, para. 36.

See, in general, Van Dijk and Van Hoof, supra note 280, at 628; Clayton and Tomlinson, supra note 270 , at 1303 \& 1314; and Ovey and White, supra note 278 , at 341 .
} 
important role in the determination of the proportionality of an interference with property. ${ }^{301}$ The European Court expressly declared so in James:

Clearly, compensation terms are material to the assessment whether the contested legislation respects a fair balance between the various interests at stake and, notably, whether it does not impose a disproportionate burden on the applicants. ${ }^{302}$

Given the common analytical approach adopted by this tribunal to all interventions with property, the practical relevance of the distinction among lesser interferences, deprivations and controls on use, lies in the payment of compensation. ${ }^{303}$ According to the case-law of the European Commission and Court, lesser interferences and controls on the use of property do not create a right to compensation. In cases of deprivation, these institutions have considered that the protection of Article 1 would be illusory and ineffective in the absence of a compensatory principle equivalent to that of European comparative law. ${ }^{304}$ Full compensation is, nevertheless, not guaranteed in all circumstances. ${ }^{305}$

\subsubsection{Lesser interferences}

The European Court of Human Rights first distinguished state interferences with property, different from deprivations or controls on its use, in the most widely

\footnotetext{
${ }^{301}$ Anderson, supra note 268 , at 548.

302 James and others case, supra note 295, para. 54.

${ }^{303}$ Anderson, supra note 268 , at 554.

${ }^{304}$ See, e.g., Pinnacle Meat Processors v. United Kingdom, Eur. Commission HR, No. 33298/96, Admissibility decision, 21 October, 1998, (1998) Eur HR Rep CD 217; Baner case, supra note 276; and Lithgow and others v. United Kingdom, Eur. Court HR, Series A No. 102, Judgment 8 July 1986, para 120.

See, also, Higgins, supra note 5, at 360; Clayton and Tomlinson, supra note 270, at 1311-13; and Mountfield, supra note 262, at 141-2.

${ }^{305}$ See. e.g., Holy Monasteries case, supra note 294, para. 71.
} 
cited judgment under Article 1 of the Protocol. ${ }^{306}$ In Sporrong, the Swedish government had granted long-term expropriation permits to the city of Stockholm. ${ }^{307}$ Although not depriving the applicants' rights by themselves, these permits gave the authorities the power to do so in the future. The city of Stockholm then adopted prohibitions on construction on the applicants' properties. After being in force for twenty three and eight years, respectively, Mr. Sporrong and Mr. Lönnroth complained that these permits made it impossible to sell or build anything in these properties, and difficult to invest or obtain mortgages for them. The applicants argued that this situation amounted to an interference with their right to a peaceful enjoyment of their possessions. The European Commission of Human Rights found no violation of Article 1, and concluded that the measures where enforced in the general interest and where thus justifiable. ${ }^{308}$ But the approach of the European Court in this case was both different and novel. Before Sporrong, it was generally assumed that claims related with Article 1 should take the form of either a deprivation or a control on the use of property. In Sporrong, the European Court found that the state can interfere with the peaceful enjoyment of possessions by measures that do not amount to deprivations or controls on its use. Applying the fair balance test between the individual and community interests, this tribunal concluded that a violation of the rule established in the first sentence of Article 1 had taken place. ${ }^{309}$

Loizidou is another example of a finding on lesser interferences. This case originated in an application against Turkey lodged with the European Commission

\footnotetext{
${ }^{306}$ C Yannaca-Small, 'Indirect Expropriation' and the 'Right to Regulate' in International Investment Law', in OECD, Working Papers on International Investment (2004), Nr. 4, at 13.

${ }^{307}$ Under the 1972 Expropriation Act.

${ }^{308}$ See Higgins, supra note 5, at 344.

${ }^{309}$ See, in general, Sporrong and Lönnroth case, supra note 294.
} 
by a Cypriot national. ${ }^{310}$ Mrs. Loizidou owned land in northern Cyprus before the Turkish occupation. After it, she was prevented from returning and enjoying her property. The Court considered the continuous denial of access to Mrs. Loizidou's land by Turkish military personnel as an interference with her rights under Article 1. But it did not regard the violation as a deprivation or a control on the use of property. The tribunal regarded the breach to "clearly fall $[\ldots]$ within the meaning of the first sentence of that provision $[\ldots]$ as an interference with the peaceful enjoyment of possessions" and observed "that hindrance can amount to a violation of the Convention just like a legal impediment". ${ }^{311}$

Although the condition of public or general interest is not expressly mentioned in this sentence of Article 1, the European Court has considered it applicable to any interference by the host-state within this provision. In Beyeler, the tribunal declared that:

The principle of a 'fair balance' inherent in Article 1 of Protocol No. 1 itself presupposes the existence of a general interest of the community. [...] it should be reiterated that the various rules incorporated in Article 1 are not distinct in the sense of being unconnected and that the second and third rules are concerned only with particular instances [...]. One of the effects of this is that the existence of a 'public interest' required under the second sentence, or the 'general interest' referred to in the second paragraph, are in fact corollaries of the principle set forth in the first sentence, so that an interference with the exercise of the right to the peaceful enjoyment of possessions within the meaning of the first sentence of Article 1 must also pursue an aim in the public interest. ${ }^{312}$

The distinction between deprivations and controls on the use of possessions is not always easy. According to van Dijk and van Hoof, when property is clearly affected by a state measure and it is not possible to identify a deprivation or a control on its use, the European Court will decide the respective case in conformity with the

\footnotetext{
${ }^{310}$ See, in general, Loizidou v. Turkey, Eur. Court HR, Reports of Judgments and Decisions 1996-VI, Judgment, 18 December, 1996.

${ }^{311}$ Ibid., para. 63.

${ }^{312}$ Beyeler v. Italy, Eur. Court HR, Reports of Judgments and Decisions 2000-I, Judgment, 5 January 2000 , para. 111.
} 
rule laid down in the first sentence of Article $1 .{ }^{313}$ Lesser interferences are, therefore, a residual category in this provision. ${ }^{314}$ Ovey and White observe that the Court has adopted a broad approach to the notion of the control on the use of property, leaving comparatively few cases to be considered under this rule. ${ }^{315}$ The European Commission and Court had found violations to the protection of peaceful enjoyment of possessions in, for instance, the refusal of a housing licence to an applicant to live in his own house ${ }^{316}$; the provisional transfer of the applicants' land to other landowners as part of a consolidation plan $^{317}$; the annulment by law of an arbitration award in favour of the applicants ${ }^{318}$; an urban development scheme which impeded the development of the applicant's property for many years ${ }^{319}$; and public interest declarations -issued as a preliminary expropriation-, and prohibitions to build or change the use of certain parcels of land. ${ }^{320}$ Anderson observes that lesser interferences:

[have] been applied to both restrictions which are consistent with Article 1 and might just as well have been characterised as controls of use, and to particularly blatant interferences which could easily have been described as deprivations. ${ }^{321}$

More recently, the European Court considered the problem of interferences with the right of peaceful enjoyment of possessions in one of the numerous cases involving claims of restitution of property from central and eastern European states.

\footnotetext{
${ }^{313}$ Van Dijk and Van Hoof, supra note 280, at 626; and A Mowbray, Cases and Materials on the European Convention on Human Rights (2007), 924.

${ }^{314}$ Anderson, supra note 268, at 546; and Gretton, supra note 271, at 278.

${ }^{315}$ Ovey and White, supra note 278 , at 319.

${ }^{316}$ See Wiggins v. United Kingdom, Eur. Commission HR, No. 7456/76, (1979) 13 Decisions and Reports 40.

${ }^{317}$ See Ekner and Hofauer v. Austria, Eur. Court HR, Series A No. 117, Judgment, 23 April 1987

${ }^{318}$ See Stran Greek Refineries and Statis Andreadis case, supra note 288.

${ }^{319}$ In fact, more than 16 years.

See Phocas v. France, Eur. Court HR, Reports of Judgments and Decisions 1996-II, Judgment, 23 April 1996.

${ }^{320}$ See Matos e Silva Lda. and others v. Portugal, Eur. Court HR, Reports of Judgments and Decisions 1996-IV, Judgment, 16 September 1996.

${ }^{321}$ Anderson, supra note 268, at 551-2.
} 
Broniowski relates to the re-drawing of the eastern border of Poland after the Second World War along the Bug River ${ }^{322}$. Polish nationals living in those territories beyond it were then repatriated and had to abandon their property. Poland took upon itself the obligation to compensate these people. As other repatriates, Mr. Broniowski was entitled to buy land from the state and have the value of his abandoned property considered in the purchase price. Because of the number of persons involved in this scheme ${ }^{323}$, Poland decided to reduce the pool of land available to them by excluding state agricultural and military property. The Polish state was therefore unable to fulfil its obligation of compensation. When this exclusion was later declared unconstitutional, Poland considered its duty to be discharged towards all those repatriates that had been somehow compensated. In the case of Mr. Broniowski, this meant approximately two per cent of the value of the house and land abandoned by his grandmother. Applying the fair balance test, the European Court concluded that the applicant "as an individual [...] had to bear a disproportionate and excessive burden which cannot be justified in terms of the legitimate general community interest pursued by the authorities". ${ }^{324}$ A violation of Article 1 was thus found.

The concept of lesser interferences developed by the European Court has exerted some influence in other international fora. It reappeared in the case-law of the Iran-US CT, particularly in its decisions construing the phrase "other measures affecting property rights". ${ }^{325}$ The notion of lesser interferences also looms, for

\footnotetext{
${ }^{322}$ See, in general, Broniowski case, supra note 281.

${ }^{323}$ From 1944 to $1953,1,240,000$ persons were repatriated. Broniowski case, supra note 281, para. 12.

${ }^{324}$ Ibid, para. 187.

${ }^{325}$ See, e.g., Foremost Tehran, Inc. et al v. The Government of the Islamic Republic of Iran et al, IranUS CT, Award No. 220-37/231-1, 11 April 1986, (1987) 10 Iran-US CTR 228; and Eastman Kodak Company, Eastman Kodak International Sales Co. and Kodak (Near East) Inc. v. The Government of Iran et al, Iran-US CT, Partial Award No. 329-227/12384-3, 11 November 1987, (1988) 17 Iran-US. CTR 153.
} 
instance, in Cinco Pensionistas, a case brought before the Inter-American Court of Human Rights. As its name indicates, Cinco Pensionistas referred to five individuals affected by an arbitrary -and considerable- de facto reduction of their pensions by Perú. ${ }^{326}$ As in Ivcher, the Inter-American Court ruled against the Peruvian state. In this case, however, the tribunal avoided any express mention of a deprivation of property, opting for rather vaguer terms as conculcar -to infringe- or violar -to breach. $^{327}$

\subsubsection{Control on the use of property}

The second paragraph of Article 1 refers to state measures that fall short of deprivation, but interfere with the right of property to a higher degree than those established in the first sentence of this provision. The state has a wide power to enforce those laws that are necessary to control the use, enjoyment or disposition of property in conformity with the general interest ${ }^{328}$, or to secure the payment of taxes. So is its margin of appreciation to judge the necessity of the measure adopted, from the standpoint of the principle of fair balance. ${ }^{329}$ This means that the review of the state action by the European Court will be limited to the establishment of a reasonable relationship of proportionality between the means employed and the aim sought to be realised. ${ }^{330}$ Compensation will not always be payable for controls on use

\footnotetext{
See, in general, Chapter 4 infra.

${ }^{326}$ See Cinco Pensionistas case, supra note 249.

${ }^{327}$ Ibid., para. 121.

${ }^{328}$ See Allen, supra note 297, at 119.

${ }^{329}$ Clayton and Tomlinson, supra note 270 , at 1317.

${ }^{330}$ Allan Jacobsson v. Sweden, Eur. Court HR, Series A No. 163, Judgment, 25 October 1989, para. 55 .
} 
of property. Its availability, however, will be one of the factors taken into account in the assessment of the balance test, and its payment should normally support a finding of non-violation of Article $1 .^{331}$ This criterion of fair balance is flexible. A measure will be disproportionate when the public interest could have been satisfied without imposing an excessive burden on someone. In practice, the European Court will not easily conclude that a fair balance between the individual and community interest was lacking. ${ }^{332}$ Chassagnou and Hutten-Czapska are rare examples of cases in which the Court found state authorities to fail the proportionality test when controlling the use of property.

Chassagnou was referred by the European Commission to the Court, and was based on the application lodged by ten French nationals claiming that the compulsory transfer of the hunting rights over their land to a municipal hunters association constituted a violation to Article $1 .^{333}$ The claimants were forced to tolerate the presence of armed men and gun dogs on their land every year, even though they did not want to hunt on their land, and objected -on ethical grounds- to the fact that others might come to it and do so. Although the Court noted that the claimants had not been deprived of their right of property, it also noted that the compulsory transfer of their hunting rights over it prevented them from using these rights which are directly linked to that of property. ${ }^{334}$ The tribunal did recognise a general interest in a

\footnotetext{
See, also, Mellacher and others v. Austria, Eur. Court HR, Series A No. 169, Judgment, 19 December 1989, para. 48; AGOSI case, supra note 295, para. 52; and Spadea and Scalabrino v. Italy, Eur. Court HR, Series A No. 315-B, Judgment, 28 September 1994, para. 33.

331 Nevertheless, in several cases the European Commission and Court have concluded that the challenged measure was proportionate, notwithstanding the failure to compensate the affected applicant for the reduction in the value of his property.

Anderson, supra note 268, at 550-1.

${ }^{332}$ Van Dijk and Van Hoof, supra note 280, at 639; and Allen, supra note 297, at 119.

${ }^{333}$ See, in general, Chassagnou and Others v. France, Eur. Court HR, Reports of Judgments and Decisions 1999-III, Judgment, 29 April, 1999.

${ }^{334}$ Ibid, para. 74.
} 
law aimed at avoiding unregulated hunting and encouraging the rational management of game stocks. ${ }^{335}$ Nonetheless, it concluded that the result of the concrete measure established by such a law -this is, compelling small landowners to transfer hunting rights over their land, so that others can make use of it in a way which is totally incompatible with their beliefs- placed the claimants in a situation which upsets the fair balance between the protection of the right of property and the requirements of the general interest. As a consequence, the European Court found the control on use to constitute a violation of Article $1 .^{336}$

Hutten-Czapska also originated in an application lodged with the European Commission, later transferred to the Court when Protocol 11 to the European Convention came into force. ${ }^{337}$ The claimant complained about the situation created by the implementation of laws which imposed tenancy agreements and set an inadequate level of chargeable rent on her property in Poland. These measures were implemented as part of special lease-schemes applied during the communist regime and temporarily after its demise. As in Chassagnou, the European Court noted that the claimant never lost her right to sell her property and that the authorities did not apply any measures resulting in the transfer of her ownership. Nevertheless, it acknowledged the fact that:

she could not exercise her right of use in terms of physical possession as the house was occupied by the tenants and that her rights in respect of letting the flats, including her right to receive rent and to terminate leases, were subject to a number of statutory limitations. ${ }^{338}$

In Hutten-Czapska, the Court again recognised a general interest in the laws enacted and implemented by the state. In this case, laws aimed at securing the social

\footnotetext{
${ }^{335} \mathrm{Ibid}$, para. 79.

${ }^{336}$ Ibid, para. 85 .

${ }^{337}$ See, in general, Hutten-Czapska v Poland, Eur. Court HR, Judgment, 22 February, 2005.

${ }^{338}$ Ibid, para. 145 .
} 
protection of tenants and ensuring the gradual transition from state-controlled rent to a fully negotiated contractual rent, during the period of reform after the collapse of a communist regime. ${ }^{339}$ The Court, however, found that the laws enacted and implemented by the state entailed a disproportionate and excessive burden on the claimant, one which cannot be justified by any legitimate interest of the community pursued by it. $^{340}$

Even though Article 1 does not expressly require controls on the use of property to be in conformity with law, the European Court has considered itself competent to review the lawfulness of these measures. ${ }^{341}$ The tribunal will respect the legislature's judgment on the general interest involved in cases of control on the use, unless that appraisal is manifestly not in accordance with law ${ }^{342}$ or without reasonable foundation. ${ }^{343}$ In this context, purposes considered to be in the general interest are, for instance, social and economic policies related with town planning ${ }^{344}$; alcohol consumption ${ }^{345}$; housing ${ }^{346}$; the protection of nature ${ }^{347}$ and the environment ${ }^{348}$; and the combat of international drugs trafficking. ${ }^{349}$ Regarding taxes, contributions, and penalties, the European Commission has declared that taxation measures will adversely affect the guarantee established in the second paragraph of Article 1 only if they place an excessive burden on the person concerned or

\footnotetext{
${ }^{339} \mathrm{Ibid}$, para. 160.

The Court had no jurisdiction over the facts that occurred before the ratification of Poland of the First Protocol to the European Convention in 1994.

See ibid., para. 140.

${ }^{340}$ Ibid., para. 188.

${ }^{341}$ Van Dijk and Van Hoof, supra note 280, at 640.

${ }^{342}$ Tre Traktorer Aktiebolag case, supra note 285, para. 58.

${ }^{343}$ Mellacher and others case, supra note 330, para. 45.

${ }^{344}$ See Allan Jacobsson case, supra note 330, para. 55.

${ }^{345}$ See Tre Traktorer Aktiebolag case, supra note 285, para. 58.

${ }^{346}$ See Mellacher and others case, supra note, para. 45.

${ }^{347}$ See Fredin case, supra note 286.

${ }^{348}$ See Pine Valley Developments Ltd and others case, supra note 278.

${ }^{349}$ See Air Canada v. United Kingdom, Eur. Court HR, Series A No. 316-A, Judgment, 5 May 1995.
} 
fundamentally interfere with his financial position. ${ }^{350}$ In relation with measures taken by the state to enforce tax obligations, the European Court has held that it will respect the authorities' assessment unless it is devoid of reasonable foundation. ${ }^{351}$ As a result, the second paragraph of Article 1 allows national authorities an almost unlimited power to impose restrictions on the use of property in accordance with the general interest. ${ }^{352}$

In contrast with the narrow reading given by the European Court to the notion of deprivation, the concept of control on the use of property has received a wider one. Clayton and Tomlinson, point out that the elimination of one of the bundle of rights comprising ownership, for instance, will usually not be enough to deprive someone of his or her ownership, but this infringement may amount to a control on the use of property. ${ }^{353}$ However, not all interference short of deprivation will necessarily be considered such an act by the European Court. ${ }^{354}$ A state may control the use of property by requiring certain actions or imposing certain restrictions in the activities of individuals and legal entities. ${ }^{355}$ The European Court has a longstanding tendency to classify measures that by most ordinary standards would be considered deprivations as controls on use. ${ }^{356}$ The seizure of obscene publications ${ }^{357}$; refusal to register as certified accountants ${ }^{358}$; withdrawal of licences ${ }^{359}$; rent controls $^{360}$;

\footnotetext{
${ }^{350}$ See Svenska Managementgruppen v. Sweden, No 11036/84, (1985) 45 Decisions and Reports 211, Wasa Liv Omsesidigt v. Sweden, Eur. Commission HR, No. 13013/87, (1988) 58 Decisions and Reports 163; and Travers and 27 others v. Italy, Eur. Commission HR, No. 15117/89, (1995) 80 Decisions and Reports 5.

${ }^{351}$ Gasus Dosier- und Fordertechnik GmbH case, supra note 281, para. 60.

${ }^{352}$ Van Dijk and Van Hoof, supra note 280, at 638.

See, also, Harris, O'Boyle and Warbrick, supra note 264, at 534.

${ }^{353}$ Clayton and Tomlinson, supra note 270 , at 1309.

${ }^{354}$ Harris, O'Boyle and Warbrick, supra note 264, at 534-5.

${ }^{355}$ See Harris, O'Boyle and Warbrick, supra note 264, at 535; and Clayton and Tomlinson, supra note 270 , at 1309 .

${ }^{356}$ Anderson, supra note 268, at 553.

${ }^{357}$ See Handyside case, supra note 291.

${ }^{358}$ See Van Marle and others case, supra note 275.
} 
planning restrictions ${ }^{361}$; temporary seizure of property in criminal proceedings ${ }^{362}$; temporary seizure of an aircraft for drugs enforcement ${ }^{363}$; and retrospective tax legislation $^{364}$, are all examples of control on the use of property. Under the second paragraph of Article 1, states are even entitled to adopt measures which affect the execution of contracts in force. ${ }^{365}$

\subsection{Expropriation in the European Convention}

According to the second sentence of Article 1, deprivations of property are permitted if the respective state measure is adopted in the public interest, subject to the conditions provided by national law, and by the general principles of international law. Expropriations, as such, are not mentioned in this provision. Nevertheless, the European Court has considered the notion of deprivation to cover not only direct takings of property, but also measures that amount to them. ${ }^{366}$ The tribunal explained in Sporrong that:

In the absence of a formal expropriation, that is to say a transfer of ownership, the Court [...] must look behind the appearances and investigate the realities of the situation complained of $[\ldots]$. Since the Convention is intended to guarantee rights that are "practical and effective" [...], it has to be ascertained whether that situation amounted to a de facto expropriation $[\ldots] .^{367}$

\footnotetext{
${ }^{359}$ See Tre Traktorer Aktiebolag case, supra note 285.

See, also, Fredin case, supra note 286.

${ }^{360}$ See Mellacher and others case, supra note 330.

${ }^{361}$ See Pine Valley Developments Ltd and others case, supra note 278.

${ }^{362}$ See Raimondo v. Italy, Eur. Court HR, Series A No. 281-A, Judgment, 22 February 1994.

${ }^{363}$ See Air Canada case, supra note 349.

${ }^{364}$ See The National \& Provincial Building Society, the Leeds Permanent Building Society and the Yorshire Building Society v. United Kingdom, Eur. Court HR, Reports of Judgments and Decisions 1997-VII, Judgment, 23 October 1997.

${ }^{365}$ Mellacher and others case, supra note 330, para. 51.

${ }^{366}$ Fredin case, supra note 286, para. 42.

${ }^{367}$ Sporrong and Lönnroth case, supra note 294, para. 63.
} 
Neither a sole-effect nor a police-powers approach is followed by the European Court on the problem of indirect takings. Ovey and White observe that the extinction of the rights of the owner will be the main criterion at the moment of determining whether a deprivation has taken place. ${ }^{368}$ However, not all acts producing this result will necessarily constitute an expropriation. They might well be treated as a control on the use of property. ${ }^{369}$ Within this context, the destruction of property will be tantamount to a deprivation. ${ }^{370} \mathrm{~A}$ restriction of rights will not constitute an expropriation, though it might be a lesser interference. ${ }^{371}$ Temporary seizures of property will not constitute deprivations, but they might amount to a control on the use of property. ${ }^{372}$ According to Clayton and Tomlinson, when there is no formal extinction of legal rights, in general:

the Court has been cautious in finding that [an] interference might nevertheless amount to 'deprivation' in fact. Such a 'de facto deprivation' can only be established where there has been a substantial interference with the enjoyment of possessions, contrary to law, without a formal divesting of the owner of title. ${ }^{373}$

\footnotetext{
${ }^{368}$ Ovey and White, supra note 278 , at 358 .

${ }^{369}$ Clayton and Tomlinson, supra note 270, at 1308.

${ }^{370}$ See, e.g., Akdivar and others v. Turkey, Eur. Court HR, Reports of Judgments and Decisions 1996IV, Judgment, 16 September 1996, para. 88.

${ }^{371}$ See, e.g., Matos e Silva, Lda. and others case, supra note 320 , paras. $79 \& 85$.

${ }^{372}$ See, e.g., Handyside case, supra note 291, para. 63.

${ }^{373}$ Clayton and Tomlinson, supra note 270, at 1308.

The approach of the European Court of Justice to the problem of indirect takings has been similar to that of the European Court of Human Rights.

See Allen, supra note 297, at 15-6, and UNCTAD, Investment Provisions in Economic Integration Agreements (2006), 109-10.

See, also, e.g., J Nold, Kohlen-und Baustoffgroßhandlung $v$ Commission of the European Communities, ECJ, Case 4-73, Judgment, 14 May, 1974. Available at

$<$ http://eur-lex.europa.eu/LexUriServ/LexUriServ.do?uri=CELEX:61973J0004:EN:HTML> (last visited 31 March, 2008);

and Liselotte Hauer $v$ Land RheinlandPfalz, ECJ, Case 44/79, Judgment 13 December, 1979. Available at

$<$ http://eur-lex.europa.eu/LexUriServ/LexUriServ.do?uri=CELEX:61979J0044:EN:HTML> (last visited 31 March, 2008)
} 


\subsubsection{Indirect takings and public interest}

One of the cases were the European Court of Human Rights did find a deprivation of property in the form of an indirect expropriation is Papamichalopoulos. This dispute related to the transference of the applicants' land to a Navy fund in Greece. Although such property was not available for state disposal under Greek law at that moment, the Navy constructed a base and a holiday resort in the area. The applicants obtained domestic judicial recognition of their titles to the land, but could not enforce these judgments. Different attempts were made to obtain from the authorities land of equal value in exchange, but all failed. The applicants further claimed damages for the land transfers without success in the Greek courts. The European Court found an interference with the applicants' right of property. Although the applicants were never formally expropriated, since the property was in fact transferred to the Navy, they were "unable either to make use of their property or to sell, bequeath, mortgage or make a gift of it" ${ }^{374}$ The European Court concluded that this interference was not for the purpose of controlling the use of property and:

that the loss of all ability to dispose of the land in issue, taken together with the failure of the attempts made so far to remedy the situation complained of, entailed sufficiently serious consequences for the applicants de facto to have been expropriated in a manner incompatible with their right to the peaceful enjoyment of their possessions. ${ }^{375}$

An indirect taking was also found by the European Court in relation with a different kind of state measure. In Hentrich, the applicants bought land in France, over which -some months later- the tax authorities of Alsace exercised a right of preemption based on a French law, then in force, that allowed the state to offer the

\footnotetext{
${ }^{374}$ Papamichalopoulos and Others v. Greece, Eur. Court HR, Series A No. 260-B, Judgment, 24 June 1993, para. 43.

${ }^{375}$ Ibid., para. 45.
} 
owners to pay the price specified in the contract of sale, and a ten per cent premium provided for by law, when the sale price was considered to be too low. The purpose of this right was to prevent tax evasion. The applicants unsuccessfully challenged the measure adopted by the French authorities in domestic courts, before turning to the European Court in search of redress. The application of the fair balance test to this case led the European Court to find a violation of Article 1, mainly because:

as a selected victim of the exercise of the right of pre-emption, Mrs Hentrich 'bore an individual and excessive burden' which could have been rendered legitimate only if she had had the possibility -which was refused her- of effectively challenging the measure taken against her. ${ }^{376}$

Another example of an indirect expropriation is Pressos Compania Naviera. In this case, the applicants' ships were involved in collisions in territorial waters of Belgium and the Netherlands, as a result of the negligence of Belgian pilots on board of these. Some of the applicants initiated legal proceedings against the Belgian state and others against a private company offering pilot services. None were successful on account of a Belgian law that exempted retroactively the state and other organisers of pilot services from their liability for negligent acts. ${ }^{377}$ According to the European Court, this law:

simply extinguished, with retrospective effect going back thirty years and without compensation, claims for very high damages that the victims of the pilot accidents could have pursued against the Belgian State or against the private companies concerned, and in some cases even in proceedings that were already pending. ${ }^{378}$

The tribunal found that a fair balance between the individual and collective interests was not kept. Therefore, an interference with the applicants' right of property had taken place. According to the European Court, a violation of Article 1 was committed, since:

\footnotetext{
${ }^{376}$ Hentrich v. France, Eur. Court HR, Series A No. 296-A, Judgment, 22 September 1994, para. 49.

${ }^{377}$ Pressos Compania Naviera S.A. and others case, supra note 289, para. 34.

${ }^{378}$ Ibid., para. 39.
} 
[t] he financial considerations cited by the Government and their concern to bring Belgian law into line with the law of neighbouring countries could warrant prospective legislation in this area to derogate from the general law of tort.

Such considerations could not justify legislating with retrospective effect with the aim and consequence of depriving the applicants of their claims for compensation. ${ }^{379}$

Directly related with the fair balance test is the notion of public interest. In conformity with the second sentence of Article 1, the measure resulting in a deprivation must be aimed at this objective. Although there is no conventional definition of such a term, the European Court has considered it to be similar to that of general interest, known in international law as public purpose. ${ }^{380}$ This condition will require a balancing of the individual and collective concerns. ${ }^{381}$ The object of such a test is to differentiate, as Higgins worded it, takings for purely private gain on the part of the ruler from those for reasons related to the economic and social preferences of the country concerned. ${ }^{382}$

The European Court has given the state great autonomy when adopting measures that interfere with the right of property. According to Ovey and White, for the tribunal there is almost a presumption that a national measure is in the public interest. ${ }^{383}$ This explains its reluctance to review the identification of the collective interest involved made by the state adopting the respective measure. ${ }^{384}$ In early cases related with takings of property, the European Commission and Court held that states had an unlimited right to determine the necessity of such deprivation. ${ }^{385}$ This almost absolute right has been replaced by the wide margin of appreciation illustrated in

\footnotetext{
${ }^{379}$ Ibid., para. 43.

${ }^{380}$ Ruiz Fabri, supra note 269, at 158.
}

See, also,. Higgins, supra note 5, at 371; and Anderson, supra note 268, at 547.

${ }^{381}$ Ovey and White, supra note 278 , at 361.

${ }^{382}$ Higgins, supra note 5, at 371.

${ }^{383}$ Ovey and White, supra note 278 , at 362.

${ }^{384}$ See Harris, O'Boyle and Warbrick, supra note 264, at 522 \& 529; Van Dijk and Van Hoof, supra note 278, at 631-2; Clayton and Tomlinson, supra note 270, at, 1315; Mountifield, supra note 262, at 140; and Ovey and White, supra note 278, at 362.

${ }^{385}$ Ruiz Fabri, supra note 269 , note 48 at 158. 
James. In this case, the applicants were trustees -acting under a will- of an area in central London where a large estate was developed. A leasehold law conferred rights of acquisition to the occupants of this estate. A number of them exercised this right and deprived the trustees of their ownership in a number of properties. The applicants claimed that this compulsory transfer gave rise to a violation of Article 1 . In essence, the applicants were complaining against the terms and conditions of the contested legislation, not against the manner of execution of the law by a state authority. ${ }^{386}$ From this perspective, the European Court started its analysis of the situation by declaring that:

a deprivation of property effected for no reason other than to confer a private benefit on a private party cannot be 'in the public interest'. Nonetheless, the compulsory transfer of property from one individual to another may, depending upon the circumstances, constitute a legitimate means for promoting the public interest. ${ }^{387}$

Not only did this tribunal consider that the taking of property in pursuance of a policy calculated to enhance social justice within the community can be properly described as being in the public interest, but also that an expropriation adopted in pursuance of a legitimate policy may be in such an interest, even if the community at large has no direct use or enjoyment of the property taken. ${ }^{388}$ The European Court's general view on the margin of appreciation provides a clear guideline on how to approach other cases involving deprivations of property for public purpose:

Because of their direct knowledge of their society and its needs, the national authorities are in principle better placed than the international judge to appreciate what is 'in the public interest'. Under the system of protection established by the Convention, it is thus for the national authorities to make the initial assessment both of the existence of a problem of public concern warranting measures of deprivation of property and of the remedial action to be taken [...].

Furthermore, the notion of 'public interest' is necessarily extensive. In particular, as the Commission noted, the decision to enact laws expropriating property will commonly involve consideration of political, economic and social issues on which

\footnotetext{
${ }^{386}$ James and others case, supra note 295, para. 36.

${ }^{387}$ Ibid., para. 40.

${ }^{388}$ Ibid., paras. $41 \& 45$.
} 
opinions within a democratic society may reasonably differ widely. The Court, finding it natural that the margin of appreciation available to the legislature in implementing social and economic policies should be a wide one, will respect the legislature's judgment as to what is 'in the public interest' unless that judgment be manifestly without reasonable foundation. ${ }^{389}$

The justification for this wide margin of appreciation is, then, that national authorities know better the needs of their societies. ${ }^{390}$ This extensive conception of public purpose makes it unlikely for any tribunal to deny the general interest claimed by the state adopting a measure that deprives someone of his or her property. ${ }^{391}$ On this basis, for instance, the European Court concluded that the leasehold law involved in James was compatible with Article 1. This margin, although considerable, is not without limits and -as the European Court declared in Broniowski- "the exercise of the State's discretion, even in the context of the most complex reform of the State, cannot entail consequences at variance with Convention standards". ${ }^{392}$ According to Ruiz Fabri:

[t]he Court's review is limited in practice to verifying whether, in the abstract, the deprivation of property has pursued a legitimate aim in the public interest. This means that any probing judicial review will focus on other criteria. ${ }^{393}$

\subsection{2.. Conditions provided for by law}

In conformity with the second sentence of Article 1, an expropriatory measure must be subject not only to the conditions established in municipal law, but also to those established in the general principles of international law. This means that any taking in breach of domestic norms amounts to a violation of Article $1 .^{394}$ The act of

\footnotetext{
${ }^{389}$ Ibid., para. 46.

${ }^{390}$ Ruiz Fabri, supra note 269, at 158.

${ }^{391}$ Ibid., 159.

${ }^{392}$ Broniowski case, supra note 281, para 183.

${ }^{393}$ Ruiz Fabri, supra note 269, at 159.

${ }^{394}$ Ovey and White, supra note 278 , at 361.
} 
deprivation adopted by the state must have a basis in municipal rules. ${ }^{395}$ The European Court has considered this condition not merely to refer back to domestic norms, but also to the quality of these rules, "requiring it to be compatible with the rule of law, which is expressly mentioned in the preamble to the Convention". ${ }^{396}$ National law should, therefore, be adequately accessible and sufficiently precise. ${ }^{397}$ In addition, it must have foreseeable consequences, and the taking itself should be surrounded by basic procedural safeguards. ${ }^{398}$ Whether the deprivation is subject to the conditions provided by municipal law requires a case-to-case analysis, where the European Court will only look for manifest violations of domestic norms. ${ }^{399}$ It will not examine the correct application of national law. In this respect, the European Court will refer to the judgment of the relevant domestic court in order not to function as a "fourth instance". ${ }^{400}$

The second sentence of Article 1 also means that any taking in breach of the general principles of international law will amount to a violation of it. These principles entitle non-nationals to protection against arbitrary expropriations by the host state in the form of compensation for the loss of their property. ${ }^{401}$ According to Ruiz Fabri, a special reference to them was a result of a compromise between states which refused any mention of compensation and states which desired such a mention. ${ }^{402}$ European case-law actually describes, in general, a form of protection

\footnotetext{
${ }^{395}$ Harris, O'Boyle and Warbrick, supra note 264, at 530.

${ }^{396}$ Malone v. United Kingdom, Eur. Court HR, Series A No. 82, Judgment, 2 August 1984, para. 67.

${ }^{397}$ Lithgow and others case, supra note 304, para. 110.

${ }^{398}$ Hentrich case, supra note 376 , para. 42.

${ }^{399}$ Ruiz Fabri, supra note 269 , note 57 at 159.

See, e.g., Allen, supra note 297, at 95.

${ }^{400}$ Van Dijk and Van Hoof, supra note 280, at 635.

${ }^{401}$ See Ovey and White, supra note 278 , at 362.

${ }^{402}$ Ruiz Fabri, supra note 269, at 151.
} 
that is very close to the requirements of these principles of international law. ${ }^{403}$ The standard of compensation is, however, only incorporated for cases of deprivation, not for those related with controls on the use or lesser interferences with property. ${ }^{404}$ Article 1 would strongly imply that there is no duty to compensate for normal regulation. $^{405}$

The European Court has concluded that a reference to the general principles of international law does not entitle nationals of the expropriating state to this guarantee. $^{406}$ While such an approach conforms to the international minimum standard enjoyed by foreigners under international law, it contradicts the equal application of human rights law in the host-state. It also runs counter the European Convention itself, for Article 14 expressly prohibits discrimination in the enjoyment of its substantive rights on grounds of national origin. The reason for this position was explained in James in the following terms:

Especially as regards a taking of property effected in the context of a social reform, there may well be good grounds for drawing a distinction between nationals and non-nationals as far as compensation is concerned. To begin with, non-nationals are more vulnerable to domestic legislation: unlike nationals, they will generally have played no part in the election or designation of its authors nor have been consulted on its adoption. Secondly, although a taking of property must always be effected in the public interest, different considerations may apply to nationals and non-nationals and there may well be legitimate reason for requiring nationals to bear a greater burden in the public interest than non-nationals. ${ }^{407}$

The tribunal confirmed their exclusion from the protection of Article 1 by referring to the travaux préparatoires of the Protocol. ${ }^{408}$ There would be, consequently, no compensation for the deprivations of the property of nationals of

\footnotetext{
${ }^{403}$ Ibid., 173.

${ }^{404}$ Clayton and Tomlinson, supra note 270, at, 1313; Higgins, supra note 5, at 360; and Mountfield, supra note 262, at 141-2.

${ }^{405}$ Yannaca-Small, supra note 306 , at 7.

${ }^{406}$ See Anderson, supra note 268, at 549.

${ }^{407}$ James and others case, supra note 295, para. 63

See, also, Lithgow and others case, supra note 304, paras. 111-9.

${ }^{408}$ James and others case, supra note 295, para. 64.
} 
the host state. At least, in theory. Due to the application of the fair balance test, however, their position is rarely -if ever- less favourable than that of nonnationals. ${ }^{409}$ As the European Court declared in Holy Monasteries:

the taking of property without payment of an amount reasonably related to its value will normally constitute a disproportionate interference and a total lack of compensation can be considered justifiable under Article 1 only under exceptional circumstances. $^{410}$

Regarding the standard of compensation in case of deprivation, the Court has not followed international law. While according to the latter, the alien is entitled to a prompt, adequate and effective compensation of the value of his of her property taken, Article 1 requires neither this standard nor the same level of compensation for every category of deprivation. ${ }^{411}$ The European Court will give the state a wide margin of appreciation when it comes to compensation. That is to say, it will respect the judgment of the domestic authorities on the terms and conditions of the compensation, unless that it is manifestly without reasonable foundation. ${ }^{412}$ For this purpose, the European Court will distinguish between nationalisations and other forms of takings, as the state's margin of appreciation appears to be wider in the former. The tribunal explained in Lithgow that:

Article 1 (P1-1) does not [...] guarantee a right to full compensation in all circumstances, since legitimate objectives of 'public interest', such as pursued in measures of economic reform or measures designed to achieve greater social justice, may call for less than reimbursement of the full market value. ${ }^{413}$

According to the European Court, the amount of compensation due in case of deprivation is that reasonably related to the value of the expropriated property. In any

\footnotetext{
${ }^{409}$ Harris, O'Boyle, and Warbrick, supra note 264, at 532; and Anderson, supra note 268, at 549.

${ }^{410}$ Holy Monasteries case, supra note 294, para. 71.

${ }^{411}$ Harris, O'Boyle, and Warbrick, supra note 264, at 533.

${ }^{412}$ Ruiz Fabri, supra note 269 , at 166.

${ }^{413}$ Lithgow and others case, supra note 304, para. 121.

See, also, Harris, O'Boyle, and Warbrick, supra note 264, at 533; and Ruiz Fabri, supra note 269, at $166 \& 170$.
} 
case, compensation must be adequate. This is, it should take into account the damage arising from the length of the deprivation, and be paid within a reasonable time. ${ }^{414}$ Excessive delays in receiving final compensation by those deprived of their property will amount to a breach of the fair balance requirement. ${ }^{415}$

\subsection{Conclusion}

The right of property of tangible and intangible assets is protected, primarily, by regional instruments of human rights. Among these, one provision stands out as the main source for the study of expropriation in this area of international law: Article 1 of the First Protocol to the European Convention. The case-law related with this provision recognises three different, but connected rules. A single test is applied to determine if the measure interfering with this right is justifiable: the observance of a fair balance between the interests of the individual and the community. National authorities have a wide margin of appreciation at the moment of establishing whether this test is observed or not. The European Court has adopted a broad notion of control on use, thus leaving few cases to be considered as deprivations or lesser interferences. A measure that interferes with the right of property to a higher degree than a lesser interference, but falls short of a deprivation, is a control on the use. The state may exercise this control by requiring certain actions or imposing certain restrictions in the activities of persons. To this respect, the power of the state is almost unlimited. The European Court will respect the judgment of the national

\footnotetext{
${ }^{414}$ Guillemin v. France, Eur. Court HR, Reports of Judgments and Decisions 1997-I, Judgment, 21 February 1997, para. 54.

${ }^{415}$ Almeida Garrett, Mascarenhas Falcão and Others v. Portugal, Eur. Cout HR, Reports of Judgments and Decisions 2000-I, Judgment, 11 January 2000, para. 54.
} 
authorities regarding the general interest involved, unless this assessment is manifestly not in accordance with law or without reasonable foundation. As with lesser interferences, the control on the use of property does not create a right to compensation for those affected by the respective measure.

The term expropriation is not expressly mentioned in Article 1. The European Commission and Court have nevertheless interpreted the notion of deprivation of possessions to cover both direct and indirect takings. The extinction of the owner's legal rights is the benchmark at the moment of establishing whether an expropriation has occurred. If there is no formal extinction of legal rights, an indirect taking will require a substantial interference with the right of property. In conformity with Article 1, measures that deprive a natural or legal person of the use of his possessions must be adopted in the public interest. This term is not defined in the First Protocol, but the European Court has identified it as general interest. In other words, public purpose, as it is commonly known in international law. This requires a fair balance between the welfare of the individual and the community. The European Court will respect the sovereign exercise by the state of its sovereign right to expropriate. A wide margin of appreciation will, therefore, be given to the national authorities at the moment of judging the public interest of the respective measure. The expropriatory act must also be subject to the conditions established by municipal and international law. This does not only mean that the measure needs to be based in domestic norms that are compatible with the rule of law. It also means that non-nationals are entitled to compensation in case of expropriation. An international minimum standard is therefore recognised to this respect, within the limits of the wording of Article 1. Full compensation, nevertheless, is not guaranteed. According to the European Court, the 
amount required by this provision is that reasonably related with the value of the taken property. Again, the state enjoys a wide margin of appreciation when establishing the standard of compensation. This range will be wider in cases of nationalisations. In practice, both nationals of the host state and foreigners are compensated for deprivations. The sole-effect doctrine is not found in Article 1 or in its interpretation by the European Court. Facts that would normally be classified as deprivations might be given the category of controls on use by this tribunal, even of lesser interferences. This situation and the lack of an absolute standard of compensation for the deprivation of property allows the European Court to take into account not only the interests of the aliens, but also those of the host state, without having to resort to the sole-effect's counterpart in cases of interference with the rights of property: the police-powers theory. 


\section{EXPROPRIATION IN THE IRAN-US CLAIMS TRIBUNAL}

The Iran-US CT was set up in 1981 as part of the political compromise reached by the Iranian and US governments. In conformity with its constitutive treaty, the tribunal was established to settle disputes between the nationals of both states arising out of interferences with a conventional international minimum standard of treatment, which protected them against expropriations and other measures affecting property rights. No definition was given in this instrument to property. The Iran-US CT chose the traditional wide notion of foreign investment, comprising tangibles and intangibles. Expropriation was interpreted by the tribunal as covering both de jure and de facto takings, the latter derived not only from acts but also from omissions. Before the establishment of the Iran-US CT, only a handful of decisions given by claims commissions, the PCIJ, arbitral tribunals and the ICJ, had referred to the expropriation of aliens. ${ }^{416}$ The judgments of the Iran-US CT formed the first clear and detailed international case-law on this issue. The link between expropriation, taking and deprivation was thus established in a generally coherent jurisprudence, which illustrates when an act constitutes one and when it does not.

The tribunal recognised and developed the protection against expropriation included in the customary international minimum standard, without losing sight of the jurisdiction given in its constitutive treaty. The Iran-US CT did not hesitate to solve the thorny issue of the state's intent at the moment of taking the property of an

\footnotetext{
${ }^{416}$ See Chapter 7 infra.
} 
alien. Adopting a sole-effect approach in most of the cases brought before it, the Iran-US CT awarded compensation when there was a non-ephemeral and unreasonable interference of the state with the enjoyment of the constituent elements of the right of property. That is to say, with the use or control of the property and of the economic benefits derived from it. The tribunal also construed and applied the notion of other measures affecting property rights, included in its jurisdiction. Through the application of this concept the Iran-US CT was able to award compensation in those situations were the deprivation did not amount to a taking. To this effect, the tribunal relied on the interpretation given by the European Commission and Court of Human Rights to the notion of lesser interferences.

The jurisprudence of the tribunal is, in general, expressly reasoned and publicly available. ${ }^{417}$ For this reason, the work of the Iran-US CT constitutes an indispensable guide for decision-makers confronted with the difficult problem of establishing the boundaries of compensable and non-compensable state measures. International arbitral tribunals in investor-to-state disputes have referred profusely in their awards to the case-law of the Iran-US CT. The present chapter studies this jurisprudence. It deals with the tribunal's definition of property and expropriation, as well as with its views on those acts that constitute a taking and those that do not. The notion of other measures affecting property rights, as developed in the case-law of this tribunal, is duly analysed too. Finally, the traditional requirements of public purpose, nondiscrimination and compensation are seen from the Iran-US CT's standpoint.

\footnotetext{
${ }^{417}$ Art. 32 of the Tribunal Rules of Procedure of 3 May 1983.

Available at <http://www.iusct.org/tribunal-rules.pdf $>$ (last visited 31 March, 2008), or reprinted in (1984) 2 Iran-US CTR 433.
} 


\subsection{Takings in an ad hoc forum}

The 1979 Iranian revolution that replaced the constitutional monarchy under the $S h a h^{418}$ for an Islamic Republic under the Rahbar ${ }^{419}$, gave rise to most -if not allthe expropriation claims presented to the Iran-US CT. ${ }^{420}$ In the context of a strong anti-Western rhetoric that led to political and civil unrest, US business dependents and representatives were gradually repatriated or forced to depart the country. The new government wanted the complete control of certain vital sectors of the economy, so banks, insurance companies, some heavy industries, and the oil industry were nationalised in 1979 and 1980. Besides direct expropriations, the Iranian government also implemented other measures that affected foreign investors. For example, it encouraged the formation of workers' councils to manage their businesses, and replaced those managers and directors designated by the respective company for those appointed by the authorities of Iran. When at the end of 1979, the US Embassy in Teheran was seized and nationals of this state were taken hostages, all existing business contacts between the two countries were brought to an end.

Iran failed to comply with the orders to release the hostages issued by the International Court of Justice in the United States Diplomatic and Consular Staff in Tehran Case. ${ }^{421}$ An unsuccessful rescue operation launched by the US ensued, as

\footnotetext{
${ }^{418}$ Persian for "monarch", the title of former Iranian rulers.

${ }^{419}$ Persian for "supreme leader", currently the highest political and religious authority in Iran.

${ }^{420} \mathrm{G}$ Aldrich, The Jurisprudence of the Iran-United States Claims Tribunal (1996), 171.

See, also, C Brower, "Current Developments in the Law of Expropriation and Compensation: A Preliminary Survey of Awards of the Iran-United States Claims Tribunal', (1987) 21 IL 639, at 641-3; or Brower and Brueschke, supra note 10, at 369-72.

${ }^{421}$ See S Riesenfeld and D Caron, 'United States-Iran Agreement of January 19, 1981 (Hostages and Financial Agreements)', in R Bernhardt (ed.), EPIL (2000), Vol. IV, at 1218-7.

See, in general, United States Diplomatic and Consular Staff in Tehran Case (US v. Iran), International Court of Justice, Provisional Measures, 15 December 1979, (1979) ICJ Rep.; and United
} 
well as the adoption of internal measures by the latter to exert economic pressure on the new government in Iran, the most important of which was the freezing of Iranian assets in the US. Negotiations finally took place between the two states during 1980 under the good offices of the Algerian government. ${ }^{422}$ The crisis was settled in 1981 through a group of treaties known as the "Algiers Accords", one of which was the Claims Settlement Declaration that established the Iran-US CT. ${ }^{423}$

\subsubsection{Defining property and expropriation}

According to Article II paragraph 1 of the Claims Settlement Declaration, the Iran-US CT was set up to resolve disputes between nationals of both countries arising, among other things, out of "expropriations and other measures affecting property rights". These disputes had to be resolved in conformity with Art. V of the same treaty. This is:

on the basis of respect for law, applying such choice of law rules and principles of commercial and international law as the Tribunal determines to be applicable, taking into account relevant usages of the trade, contract provisions and changed circumstances. ${ }^{424}$

Although Article II paragraph 1 did not define "property rights", the tribunal followed the general approach in international legal practice and opted for a broad notion of property, including both tangibles and intangibles. This solution followed

States Diplomatic and Consular Staff in Tehran Case (US v. Iran), International Court of Justice, Partial Judgment, 14 May 1980, (1980) ICJ Rep.

${ }^{422}$ See Riesenfeld and Caron, supra note 421 , at 1218-9.

${ }^{423}$ Declaration of the Government of the Democratic and Popular Republic of Algeria Concerning the Settlement of Claims by the Government of the United States of America and the Government of the Islamic Republic of Iran, (1983) 1 Iran-US CTR 9, or (1981) 20 ILM 231. Also available at $<$ http://www.iusct.org/claims-settlement.pdf> (last visited 31 March, 2008).

Besides the Claims Settlement Declaration, the Algiers Accords consisted of three political agreements and two technical ones.

See Brower, supra note 420, at 640; and Riesenfeld and Caron, supra note 421, at 1219.

${ }^{424}$ See J Wetsberg, 'Applicable Law, Expropriatory Takings and Compensations in Cases of Expropriation: ICSID and Iran - United States Claims Tribunal Case Law Compared', (1993) 8/I ICSID Rev. 1, at 5-6 \& 8-10. 
that adopted by the 1922 Norwegian Shipowner's claim, the 1926 Chorzow Factory

case, and the 1934 Oscar Chinn case. ${ }^{425}$ In the interlocutory award of Starrett, the Iran-US CT declared that property must be deemed to comprise physical assets as well as contract rights. ${ }^{426}$ This wide concept was confirmed in the final award of the same case, where the tribunal stated that "[i]t is a well-settled rule of customary international law that a taking of one property right may also involve a taking of a closely connected ancillary right" ${ }^{427}$ In conformity with this broad notion of property, management rights ${ }^{428}$, the right to receive dividend payments ${ }^{429}$, and other shareholders' rights and interests ${ }^{430}$, inter alia, would be included within the Claims Settlement Declaration. The partial award of Amoco International Finance gave a concept of takings that illustrates the wide scope of its object:

[e]xpropriation, which can be defined as a compulsory transfer of property rights, may extend to any rights which can be the object of a commercial transaction, i.e. freely sold and bought, and thus has a monetary value. ${ }^{431}$

\footnotetext{
${ }^{425}$ See Norwegian Shipowners (Norway v. US), Anderson, Vogt, and Valloton, arbitrators, Award, 13 October, 1922, (1922) 1 RIAA 307, at 325; Factory at Chorzow case (Germany v Poland), PCIJ, Judgment, 25 May 1926, (1926) PCIJ Rep. Series A No 7, at 44; and Oscar Chinn (UK v. Belgium), PCIJ, Judgment, 12 December, 1934, (1934) PCIJ Rep. Series A/B No 63, at 88.

See, also, A Reinisch, 'Expropriation', 5-7. Unpublished paper of the International Law Association's Committee on International Law on Foreign Investment, available at $<\mathrm{http} / / \mathrm{www}$.ilahq.org/pdf/Foreign\%20Investment/ILA\%20paper\%20Reinisch.pdf> (last visited 31 March, 2008).

${ }^{426}$ Starrett Housing Corporation, Starrett Systems, Inc., Starrett Housing International, Inc., $v$ The Government of the Islamic Republic of Iran et al, Iran-US CT, Interlocutory Award No. ITL 32-24-1, 19 December 1983, (1985) 4 Iran-US CTR 122, at 156-7.

${ }^{427}$ Starrett Housing Corporation, Starrett Systems, Inc., Starrett Housing International, Inc., $v$ The Government of the Islamic Republic of Iran et al, Iran-US CT, Final Award No. ITL 314-24-1, 14 August, 1987, (1988) 16 Iran-US CTR 122, at 230.

See, also, Phillips Petroleum Company Iran $v$ The Islamic Republic of Iran and The National Iranian Oil Company, Iran-US CT, Award No. 425-39-2, 29 June, 1989, (1990) 21 Iran-US CTR 79, at 115.

${ }^{428}$ See SEDCO, Inc., and Sediran Drilling Company v. National Iranian Oil Company, and The Islamic Republic of Iran, Iran-US CT, First Interlocutory Award No ITL 55-129-3, 28 October 1985, (1987) 9 Iran-US CTR 248, at 277.

${ }^{429}$ See Foremost Tehran, Inc. et al case, supra note 325, at 244-50.

${ }^{430}$ See Thomas Earl Payne v. The Government of the Islamic Republic of Iran, Iran-US CT, Award No. 245-335-2, 8 August 1986, (1988) 12 Iran-US CTR 3, at 7-11.

See, in general, Brower and Brueschke, supra note 10, at374-5.

${ }^{431}$ Amoco International Finance Corporation v. The Government of the Islamic Republic of Iran et al, Iran-US CT, Partial Award No. 310-56-3, 14 July 1987, (1988) 15 Iran-US CTR 189, at 220.
} 
This scope was, nonetheless, not unlimited. The tribunal excluded, for instance, claims that sought compensation for personal injuries. ${ }^{432}$

The Iran-US CT considered expropriation and taking to be synonyms. According to Mouri a distinction appears to have been made between these concepts and deprivation. As he explains, in the tribunal's case-law "expropriation always results in a deprivation of the owner of that property or right", but "the converse is not always true: deprivation is not in all circumstances an act of expropriation". ${ }^{433}$ In most cases where a deprivation was found, however, the tribunal did conclude that it amounted to a taking. ${ }^{434}$ Judge Brower declared in Eastman Kodak that an expropriation usually implies "that the State involved has itself acquired the benefit of the affected alien's property or at least has been the instrument of its redistribution". ${ }^{435}$ Acknowledging that this might not always be the case, in Tippets, Abbett, McCarthy, Stratton (TAMS) the tribunal preferred to use "deprivation" over "taking", because "the latter may be understood to imply that the Government has acquired something of value, which is not required" ${ }^{436}$ Nevertheless, the Iran-US CT concluded in the same case that both:

A deprivation or taking of property may occur under international law through interference by a state in the use of that property or with the enjoyment of its benefits, even where legal title to the property is not affected. ${ }^{437}$

\footnotetext{
${ }^{432}$ See Manuchehr Haddadi v. The United States of America, Iran-US CT, Award No 162-763-3, 31 January 1985, (1987) 8 Iran-US CTR 20, at 22.

See, also, Jack Rankin v. The Islamic Republic of Iran, Iran-US CT, Award No 326-10913-2, 3 November 1987, (1988) 17 Iran-US CTR 135, at 148.

${ }^{433}$ Mouri, supra note 10 , at 88.

See, also, ibid., 66-9.

${ }^{434}$ G Aldrich, 'What Constitutes a Compensable Taking: The Decisions of the Iran-United States Claims Tribunal', (1994) 88 AJIL 585, at 589; or Aldrich, supra note 420, at 178; and Wetsberg, supra note 424 , at 15 .

${ }^{435}$ Eastman Kodak Company, Eastman Kodak International Sales Co., and Kodak Inc. case, supra note 325, Concurring and Dissenting Opinion of Judge Brower, at $173 \& 181$.

${ }^{436}$ Tippets, Abbett, McCarthy, Stratton (TAMS) v. TAMS-AFFA Consulting Engineers of Iran, The Government of the Islamic Republic of Iran et al, Iran-US CT, Award No. 141-7-2, 29 June 1984, (1986) 6 Iran-US CTR 219, at 225.

${ }^{437}$ Ibid.
} 
As illustrated in this last paragraph, the Iran-US CT construed the term "expropriation" used in the Claims Settlement Declaration to cover not only de jure, but also de facto takings. ${ }^{438}$ The tribunal dealt with few claims of direct expropriation, and it had no problems in finding that a taking took place when there was an Iranian law expressly nationalising an industry or a particular entity. ${ }^{439}$ The majority of the cases brought before the tribunal were related with claims of indirect expropriation, where either there was a de facto seizure of property without any formal declaration announcing the taking, or there was such formal declaration, but a de facto taking had allegedly occurred at an earlier date. ${ }^{440}$ Both acts and omissions were included in the tribunal's case-law on indirect expropriation. The Iran-US CT generally required an affirmative action from the government that adopted the challenged measure before finding that a taking attributable to the latter had occurred. ${ }^{441}$

The tribunal further distinguished the term "taking" or "expropriation" from "appropriation", the latter being not an act of the state, but of a private person -like the party to a contract- that results in the owner's deprivation. ${ }^{42}$ Brower and Brueschke point out that the tribunal's awards often seem "somewhat lax" when keeping strict conceptual distinctions between acts constituting "expropriation", "deprivation", or "appropriation". According to them, the main reason for this attitude

\footnotetext{
${ }^{438}$ See Mouri, supra note 10, at 70-99; and Brower and Brueschke, supra note 10, at 376-83.

${ }^{439}$ See, e.g., American International Group, Inc. and American Life Insurance Company v. Islamic Republic of Iran and Central Insurance of Iran, Iran-US CT, Award No 93-2-3, 19 December 1983, (1985) 4 Iran-US CTR 96; or Amoco International Finance case, supra note 431.

${ }^{440}$ See Brower and Brueschke, supra note 10, at 377-8.

See, also, M Brunetti, 'The Iran-United States Claims Tribunal, NAFTA Chapter 11, and the Doctrine of Indirect Expropriation', (2001) 2 Chic. JIL 203, at 205.

${ }^{441}$ Brower and Brueschke, supra note 10, at 383 .

${ }^{442}$ Mouri, supra note 10, at 172-4.

See, e.g., SEDCO, Inc. v National Iranian Oil Company and The Islamic Republic of Iran, Iran-US CT, Award No. 309-129-3, 7 July, 1987, (1988) 15 Iran-US CTR 23; and Component Builders, Inc., Wood Components Co. and Moshofsky Enterprises v. The Islamic Republic of Iran, Bank Maskan Iran and Insurance Company of Iran, Iran-US CT, Award No. 431-395-3, 10 August, 1989, (1991) 23 Iran-US CTR 3, at 25-7.
} 
was the fact that a decision of the tribunal was "immediately and automatically satisfied from the Security Account, regardless of [its] theoretical basis". ${ }^{443}$

The establishment of the date of the taking was a difficult task for the judges. Most of the indirect expropriation cases presented before the tribunal corresponded to claims of creeping or constructive takings. This date was important not only in relation to the jurisdictional deadline fixed in the constitutive treaty of the Iran-US $\mathrm{CT}^{444}$, but also for the valuation of the property taken, the determination of the exchange rate of the currency in which the compensation was to be paid, and the moment from which the interest was to run on the award. ${ }^{445}$ International Technical Products gave a solution to this problem in the following terms:

Where the alleged expropriation is carried out by way of a series of interferences in the enjoyment of the property, the breach forming the cause of action is deemed to take place on the day when the interference has ripened into more or less irreversible deprivation of the property rather than on the beginning date of the events. The point at which interference ripens into a taking depends on the circumstances of the case and does not require that legal title has been transferred. ${ }^{446}$

In this case, the Iran-US CT considered expropriation claims to be outstanding "on the date of the taking of property". This standard was later followed by several other awards. $^{447}$

\footnotetext{
${ }^{443}$ Brower and Brueschke, supra note 10 , at 380 .

${ }^{444}$ The tribunal had jurisdiction over claims and counterclaims that were outstanding on the $19^{\text {th }}$ of January, 1981.

Art. II para. 1 of the Claims Settlement Declaration. See note 432, supra.

${ }^{445}$ Brower and Brueschke, supra note 10, at 430-1.

${ }^{446}$ International Technical Products Corporation and ITP Export Corporation v. The Government of Islamic Republic of Iran et al, Iran-US CT, Award No. 196-302-3, 24 October, 1985, (1987) 9 IranUS CTR 206, at 240-1.

${ }^{447}$ See, e.g., International Systems \& Controls Corporation v. The Islamic Republic of Iran et al, IranUS CT, Award No. 256-439-2, 26 September, 1986, (1988) 12 Iran-US CTR 239, at 263; and Reza Said Malek v. The Government of the Islamic Republic of Iran, Iran-US CT, Award No. 534-193-3, 11 August, 1992, (1996) 28 Iran-US CTR 246, at 288-9.
} 


\subsubsection{Other measures affecting property rights}

The international minimum standard, applicable under the Claims Settlement Declaration, offered Iranian and US nationals a protection that went beyond that traditionally offered by the law of expropriation. This instrument gave the Iran-US CT jurisdiction over disputes arising not only out of expropriations, but also out of "other measures affecting property rights". The tribunal found deprivations that fitted this description in a number of cases where the level of the interference did not amount to an actual taking. ${ }^{448}$ This phrase was given a broad meaning, and a variety of measures -whether actions or omissions, and irrespective of their form of execution- were considered to be able to affect the property of Iranian or US nationals. Even the failure to exert due diligence in the protection of the foreign investor, or a tortious act affecting his property, were exceptionally accepted as included in this phrase. ${ }^{449}$ According to Mouri, in general:

the Tribunal's awards based on the phrase 'other measures affecting property rights' required a threshold showing that the State committed serious, specific, and unreasonable acts of interference with the actual use and benefit of a particular property or with the fundamental property rights of a given claimant, with irreversible deprivative consequence similar to that arising from expropriation. ${ }^{450}$

Heiskanen points out that the Iran-US CT resorted to "other measures" exceptionally, and that only few claims were resolved solely on this basis, while the

\footnotetext{
${ }_{448}^{44}$ Mouri, supra note 10, at 67-8: and Brower and Brueschke, supra note 10, at 379.

${ }^{449}$ See, e.g., Schering Corporation $v$ The Islamic Republic of Iran, Iran-US CT, Award No. 122-38-3, 11 April 1984, (1985) 5 Iran-US CTR 361; and Alfred L. W. Short v The Islamic Republic of Iran, IranUS CT, Award No. 312-11135-3, 14 July 1987, (1988) 16 Iran-US CTR 76.

Cf. Lillian Byrdine Grimm v The Islamic Republic of Iran, Iran-US CT, Award No. 25-71-1, 22 February, 1983, (1984) 2 Iran-US CTR 78, at 79; and International Systems \& Controls Corporation case, supra note 447 , at $263-4$.

See, in general, Mouri, supra note 10, at 119-29.

${ }^{450}$ Mouri, supra note 10 , at 129.
} 
bulk of them involved takings. ${ }^{451}$ The tribunal found the Iranian authorities liable for subjecting the claimant to "other measures" in TAMS. An equally owned entity called TAMS-AFFA had been created in 1975 by TAMS, a US partnership, and an Iranian firm $(\mathrm{AFFA})^{452}$, for the sole purpose of performing engineering and architectural services on the Tehran International Airport. TAMS-AFFA's articles of partnership established the joint control of the entity by its partners. This meant that any decision should require the consent of at least one member appointed by TAMS and one member appointed by AFFA, and that the authority to sign documents creating obligations for TAMS-AFFA was vested in two individuals, one appointed by each partner. At the beginning of 1979 , the Tehran International Airport project stopped almost completely as a result of the Iranian revolution. The government of Iran appointed then a temporary manager for AFFA, who also assumed as manager of TAMS-AFFA and started to sign by himself checks on its behalf, as well as making personnel and other decisions without consulting TAMS. Negotiations took place during 1979 between the US company and the manager of TAMS-AFFA with some success, but this trend was reversed after the hostage crisis occurred at the end of the same year, and TAMS-AFFA stopped reporting to the foreign investor and responding to its letters and faxes. The Iran-US CT considered TAMS to be deprived of its property interests in TAMS-AFFA from this moment. However, no taking was found. The tribunal concluded that Iran was responsible for "other measures" affecting the claimant's rights. ${ }^{453}$

Foremost Tehran is another example of a lesser interference with the property of a foreign investor. That is to say, one that did not amount to an expropriation. In

\footnotetext{
${ }^{451}$ Heiskanen (2003), supra note 60, at 179; and Heiskanen (2007), supra note 60, at 219.

${ }^{452}$ Aziz Farmanfarmaian and Associates.

${ }^{453}$ See Tippets, Abbett, McCarthy, Stratton (TAMS) case, supra note 436, at 225.
} 
this case, a US group of companies (Foremost) owned a percentage in an Iranian joint stock company (Pak Dairy). ${ }^{454}$ After expatriating its personnel in Iran, Pak Dairy declared dividends in 1979, 1980 and 1981, and paid them to Iranian stockholders, while refusing to pay them to the foreign investor. ${ }^{455}$ One of Foremost's main representatives in Iran was ousted by the government from the board of directors in 1980 and replaced by an Iranian national acting on the instructions of his state. That same year, Pak Dairy's board informed Foremost its decision of making no payments to foreign shareholders. The US group claimed before the tribunal that a taking of its interest in the company had occurred as a "cumulative result of a number of instances of interference with the exercise of its rights as a shareholder". ${ }^{456}$ The Iran-US CT established that the non-payment of dividends to Foremost was an interference with its rights, compensable under the rubric of "other measures affecting property rights". The tribunal supported its conclusion by reference to the Sporrong case, decided by the European Court of Human Rights in 1982, where a violation of Article 1 of the First Optional Protocol of the European Convention on Human Rights was found in the form of a lesser interference with the protected peaceful enjoyment of possessions. $^{457}$

In Eastman Kodak, a US investor established in Iran a corporation to act as distributor of its products and to operate a finishing photo laboratory (Rangiran). ${ }^{458}$ With the advent of the Iranian revolution in 1978, Eastman Kodak's expatriate management personnel left the country. Rangiran continued functioning with Iranian

\footnotetext{
${ }^{454}$ Sherkat Sahami Labaniat Pasteurize Pak.

${ }^{455}$ Exceptionally, the stock dividend declared in 1980 was distributed to Foremost too.

${ }^{456}$ See Foremost Tehran, Inc. et al case, supra note 325, at 224.

${ }^{457}$ See ibid., 251-2.

See, also, Chapter 3 supra.

${ }^{458}$ Rangiran Photographic Services Co.
} 
nationals appointed by the foreign investor, who where later joined by a couple of US nationals that returned to assume management functions in Iran. After the hostage crisis in 1979, these last remaining expatriate officers left the country, and Rangiran's accounts in Iranian banks were frozen by order of the government of Iran. A worker's council conformed by employees of the company was then instructed to assume the supervision of Rangiran and an Iranian national was appointed as its manager by the state. The shareholders of the company decided in 1980 to place it in liquidation. The worker's council accepted this decision, but later Iran sealed Rangiran's office building, preventing the personnel from working until the company appointed a liquidator acceptable to the government. The board of liquidators appointed by the shareholders of the company declared Rangiran as bankrupt, an action that was later confirmed by a court in Tehran. In its partial award the Iran-US CT found no expropriation, especially because "the Claimant, as majority shareholder, was able effectively to decide to liquidate and to declare Rangiran bankrupt". ${ }^{459}$ Nevertheless, expressly following the Sporrong case and the award in Foremost, the tribunal was satisfied that Eastman Kodak's claim for expropriation "must be taken to include a claim for a lesser degree of interference with its property rights" and concluded that Iran's actions amounted to "other measures". 460

Karubian was yet another award based on "other measures affecting property rights". In this proceeding, the Iranian state enacted land-reform acts in 1979 and 1982 by which certain undeveloped plots should become government property. The implementation and enforcement of these norms remained contingent upon the determination that the respective immovables were in fact undeveloped, but no such

\footnotetext{
${ }^{459}$ Eastman Kodak Company, Eastman Kodak International Sales Co. and Kodak (Near East) Inc.case, supra note 325, at 169.

${ }^{460} \mathrm{Ibid}$.
} 
action was taken regarding Mr. Karubian's properties. The uncertainty as to the status of these plots produced doubts over the ownership of the lands, since the correspondent title deeds were susceptible of being cancelled at any time. Quoting both Foremost Tehran and Eastman Kodak, the Iran-US CT found no expropriation resulting from the Iranian legislation. The tribunal concluded, nonetheless, that the uncertainty surrounding the ownership of the properties would have made it difficult for the claimant to find a buyer for his plots. This situation represented an impairment of his right to dispose of them and adversely affected Karubian's property under the Claims Settlement Declaration. ${ }^{461}$ The facts of this case bring to mind those of the Sporrong case and it came as no surprise that the Iran-US found no expropriation out of the state's legislation, but "other measures affecting property rights".

\subsection{The problem of indirect takings}

The findings on expropriation of the Iran-US CT depended on the circumstances that surrounded the respective claim and the type of property that was taken. ${ }^{462}$ Almost in all of these cases, the tribunal applied customary international law. ${ }^{463}$ In Harza Engineering, the Iran-US CT agreed with the claimant's assertion "that a taking of property may occur under international law, even in the absence of a formal nationalization or expropriation, if a government has interfered unreasonably with the use of property". ${ }^{464}$ Other cases in which this standard was followed include

\footnotetext{
${ }^{461}$ Rouhollah Karubian v. The Government of the Islamic Republic of Iran, Iran-US CT, Award No. 569-419-2, 6 March, 1996, (1996) 8/III WTAM 177.

${ }^{462}$ See Brower and Brueschke, supra note 10 , at 378-9.

${ }^{463}$ Brunetti, supra note 440 , at 205.

${ }^{464}$ Harza Engineering Company v. The Islamic Republic of Iran, Iran-US CT, Award No. 19-98-2, 30 December 1982, (1983) 1 Iran-US CTR 499, at 504.
} 
Ataollah Golpira and International Technical Products. ${ }^{465}$ The description of the standard was different in other decisions. For instance, in the interlocutory award of Starrett, the Iran-US CT stated that under international law "measures taken by a State can interfere with property rights to such an extent that these rights are rendered so useless that they must be deemed to have been expropriated". ${ }^{466}$ TAMS, on the other hand, considered a taking to occur "whenever events demonstrate that the owner was deprived of fundamental rights of ownership and it appears that this deprivation is not merely ephemeral". ${ }^{467}$ According to Brower and Brueschke, this requirement "is somewhat ambiguous but generally should be taken to mean that the deprivation is not of such a temporary or short duration that compensation should not be awarded". ${ }^{468}$ In Gianoplus, the Iran-US CT came out with yet another description, when it declared that "[u]nder appropriate circumstances government interference depriving an owner of effective use and control of property may give rise to a claim for expropriation". ${ }^{469}$ This standard of "effective deprivation" had already been used by the PCIJ in the Chorzow Factory and Oscar Chinn cases. ${ }^{470}$

\footnotetext{
${ }^{465}$ Ataollah Golpira v. The Islamic Republic of Iran, Iran-US CT, Award No. 32-211-2, 29 March, 1983, (1984) 2 Iran-US CTR 171, at 177; and International Technical Products Corporation and ITP Export Corporation case, supra note 446, at 238-9.

${ }^{466}$ Starrett Housing Corporation, Starrett Systems, Inc., Starrett Housing International, Inc. case, supra note 426 , at 154 .

See, also, Foremost Tehran, Inc. et al case, supra note 325, at 244.

${ }^{467}$ Tippets, Abbett, McCarthy, Stratton (TAMS) case, supra note 436, at 225.

See, also, Phelps Dodge Corp. and Overseas Private Investment Corp. v. The Islamic Republic of Iran, Iran-US CT, Award No. 217-99-2, 19 March, 1986, (1987) 10 Iran-US CTR 121, at 130.

${ }^{468}$ Brower and Brueschke, supra note 10 , note 1763 at 378.

${ }^{469}$ Constantine A. Gianoplus $v$. The Government of the Islamic Republic of Iran, Iran-US CT, Award No. 237-314-1, 20 June, 1986, (1988) 11 Iran-US CTR 217, at 221.

See, also, Starrett Housing Corporation, Starrett Systems, Inc., Starrett Housing International, Inc. case, supra note 426, at 156.

${ }^{470}$ See Sedigh, supra note 8, at 644-6.
} 


\subsubsection{Constitutive acts}

All the nuances in the wording employed by the tribunal might suggest that there was more than one applicable standard. It is clear, however, that the case-law of the Iran-US CT did not focus on semantics, but on the impact of the alleged taking. Brower explains that the standard applied explicitly and implicitly by the tribunal required an unreasonable interference with the foreigner's property caused by actions attributable to the host-state. ${ }^{471}$ What in fact constituted this unreasonable interference varied depending on the circumstances of the respective case, to the point where according to Brower and Brueschke- it is impossible to discern in Iran-US CT's caselaw a single standard for determining when an expropriation has occurred. ${ }^{472}$ Sedigh even concluded that "the boundary between regulation and expropriation becomes the unreasonableness of an interference, and the unreasonableness of an interference would depend on the nature of the affected property and the means used" ${ }^{473}$ Such a conclusion would imply that the Iran-US CT adopted a police-powers solution, when it actually applied the sole-effect rule in most expropriation claims. In other words, the tribunal's answer to the threshold question called for something more than just an unreasonable interference.

The finding of a formal or informal expropriation by the Iran-US CT required the establishment of two facts by the claimant. The first one was that a taking of possession, a transfer of property, or its distribution by the state had occurred. The

\footnotetext{
${ }^{471}$ Brower, supra note 420 , at 644 .

${ }^{472}$ Brower and Brueschke, supra note 10, at 440.

See, also, Pellonpää and Fitzmaurice, supra note 8 , at 85 .

${ }^{473}$ Sedigh, supra note 8 , at 682.
} 
second one was the denial of its use to the owner. ${ }^{474}$ The Iran-US CT applied both requirements to cases involving the indirect taking of physical properties and business operations. In those cases involving the seizure of tangible objects, the tribunal had no difficulties in finding a taking from the date that the owner's access to his property was obstructed, if the correspondent act was attributable to the Iranian government. ${ }^{475}$ In this respect, even acts performed by the judiciary were considered to be susceptible of producing expropriatory effects. ${ }^{476}$ The tribunal's conclusion in Dames and More, that a "unilateral taking of possession of property and the denial of its use to the rightful owners may amount to an expropriation even without a formal decree regarding title to the property" ${ }^{\prime 47}$, is an example of the application of these conditions to a particular claim of this type. ${ }^{478}$ Concerning companies and business operations, the Iran-US CT replaced the first requirement -i.e. the taking of possession, transfer or distribution of the property by the state- with that of irreversible control by the state over the business or company, and the second requirement -the denial of the property's use to the owner- with that of deprivative consequences of such control

\footnotetext{
${ }^{474}$ Mouri, supra note 10 , at 88 .

${ }^{475}$ Pellonpää and Fitzmaurice, supra note 8, at 86; and Brower and Brueschke, supra note 10, at 434 . See American Bell International, Inc., v. The Islamic Republic of Iran et al, Iran-US CT, Award No. 255-48-3, 19 September, 1986, (1988) 12 Iran-US CTR 170, at 214-5; and Kenneth P. Yeager v. The Islamic Republic of Iran, Iran-US CT, Partial Award No. 324-10199-1, 2 November, 1987, (1988) 17 Iran-US CTR 92, at 108-9.

See, in general, Brower and Brueschke, supra note 10, at 384-91.

${ }_{476}$ See Oil Field of Texas, Inc., v. The Government of the Islamic Republic of Iran and National Iranian Oil Company, Iran-US CT, Award No. 258-43-1, 8 October, 1986, (1988) 12 Iran-US CTR 308 , at 318 .

${ }^{477}$ Dames \& More v. The Islamic republic of Iran et al, Iran-US CT, Award No. 97-54-3, 20 December, 1983, (1985) 4 Iran-US CTR 212, at 223.

${ }^{478}$ See, also, William L. Pereira Associates v. Islamic Republic of Iran, Iran-US CT, Award No. 116-13, 19 March, 1984, (1985) 5 Iran-US CTR 198; Computer Sciences Corporation v. The Government of the Islamic Republic of Iran et al, Iran-US CT, Award No. 221-65-1, 16 April, 1986, (1987) 10 Iran-US CTR 269; Sola Tiles, Inc., v. The Government of the Islamic Republic of Iran, Iran-US CT, Award No. 298-317-1, 22 April, 1987, (1988) 14 Iran-US CTR 223; and Leonard and Mavis Daley v. The Islamic Republic of Iran, Iran-US CT, Award No. 360-10514-1, 20 April, 1988, (1989) 18 IranUS CTR 232.
} 
over virtually all of the value of the owner's property. ${ }^{479}$ In ITT, Jugde Aldrich held

that:

while assumption of control over property by a government does not automatically and immediately justify a conclusion that the property has been taken by the government, thus requiring compensation under international law, such a conclusion is warranted whenever events demonstrate that the owner was deprived of fundamental rights of ownership and it appears that this deprivation is not merely ephemeral. ${ }^{480}$

This rule was followed by the Iran-US CT in other awards. ${ }^{481}$ In this context, the tribunal assessed the appointment of managers and supervisors by the Iranian state pursuant to newly-enacted legislation as an "important", "significant", or "relevant" factor, but not conclusive at the moment of establishing whether an expropriation had occurred. ${ }^{482}$ The decisive element for making this finding was, as Aldrich explains, that the deprivation of property produced as a consequence of such a measure was not transitory. ${ }^{483}$ In the words of the interlocutory award of SEDCO, when there is "no reasonable prospect of return of control, a taking should conclusively be found to have occurred as of that date". ${ }^{484}$ According to Brower and Brueschke:

given the factual nature of the Tribunal's inquiry its decisions have never fixed on a mechanical standard for determining whether or when the appointment of managers has effected a taking. It has considered many factors, including whether the owner has been excluded from the ordinary dissemination of financial information and income distributions, as well as the scope of functions assumed by the Governmentappointed managers. ${ }^{485}$

\footnotetext{
${ }^{479}$ Mouri, supra note 10 , at 94.

See, in general, Brower and Brueschke, supra note 10, at 394-410.

${ }^{480}$ ITT Industries, Inc., $v$. The Islamic Republic of Iran and The Organisation of Nationalised Industries of Iran, Iran-US CT, Award on Agreed Terms No. 47-156-2, 26 May, 1983, Concurring Opinion of Judge Aldrich, (1984) 2 Iran-US CTR 348, at 351-2.

${ }^{481}$ See, e.g., Tippets, Abbett, McCarthy, Stratton (TAMS) case, supra note 436, at 225.

${ }^{482}$ See Thomas Earl Payne case, supra note 430, at 11; Motorola, Inc., v. Iranian National Airlines Corporation and the Government of the Islamic Republic of Iran, Iran-US CT, Award No. 373-481-3, 28 June, 1988, (1989) 19 Iran-US CTR 73, at 85; and James M. Saghi, Michael R. Saghi and Allan J. Saghi v. The Islamic Republic of Iran, Iran-US CT, Award No. 544-298-2, 22 January, 1993, (2000) 29 Iran-US CTR 20, at 41 \& 44-5.

See, also, Sedigh, supra note 8, at 648-9.

${ }^{483}$ Aldrich, supra note 434 , at 592.

${ }^{484}$ SEDCO, Inc., and Sediran Drilling Company case, supra note 428, at 276-9.

${ }^{485}$ Brower and Brueschke, supra note 10 , at 398.
} 
The Iran-US CT often recognised that an ephemeral interruption of control would not constitute by itself an expropriation. ${ }^{486}$ In practice, however, the tribunal generally considered the correspondent assumption by the government-appointed individual to be definitive or permanent rather than provisional or temporary, as labelled by the Iranian state. Exceptionally, the tribunal did find an interference to be temporal in Motorola. ${ }^{487}$ Aldrich points out that:

by the time the first claims for expropriation or other takings of property began to be decided by the Tribunal in late 1983, the interference with property rights had endured for at least three years or more, and the continuation of strained relations between Iran and the United States gave the Tribunal little reason to believe that such interference would soon end. Consequently, the often difficult question of when allegedly temporary interference with the rights of property owners should be considered to have ripened into a compensable taking or deprivation of those rights rarely troubled the Iran-United States Claims Tribunal. ${ }^{488}$

In most cases involving the interference of the control over property, the tribunal came to the conclusion that the respective expropriation occurred precisely at this moment, i.e. when the manager or supervisor assumed his duties. ${ }^{489}$

Besides the physical seizure of property or its deprivation through the appointment of managers or supervisors, the Iran-US CT found an expropriation in cases involving, for instance, involuntary or forced transactions ${ }^{490}$; the refusal of the Iranian government to return property subject to a lease ${ }^{491}$; the loss of goods left with that state ${ }^{492}$; and its failure to grant a re-export permit for equipment in Iran. ${ }^{493}$

\footnotetext{
${ }^{486}$ Aldrich, supra note 420, at 187.

${ }^{487}$ See Motorola, Inc., case, supra note 482 , at 85

${ }^{488}$ Aldrich, supra note 420, at 172.

${ }^{489}$ Aldrich, supra note 434 , at 589.
}

See, e.g., Harold Birnbaum v. The Islamic Republic of Iran, Iran-US CT, Award No. 549-967-2, 6 July, 1993, (2000) 29 Iran-US CTR 260.

${ }^{490}$ See American Bell International, Inc. case, supra note 475.

${ }^{491}$ See Oil Field of Texas, Inc. case, supra note 476, at 319.

${ }^{492}$ See United Painting, Inc., v. The Islamic Republic of Iran, Iran-US CT, Award No. 458-11286-3, 20 December, 1989, (1991) 23 Iran-US CTR 351.

${ }^{493}$ See Petrolane, Inc., Eastman Whipstock Manufacturing, Inc., and Seahorse Fleet, Inc., v. the Government of the Islamic Republic of Iran et al, Iran-US CT, Award No. 518-131-2, 14 August, 1991, (1992) 27 Iran-US CTR 64. 


\subsubsection{Claims that were rejected}

In a number of cases, no taking was found by the Iran-US CT. Expropriation

claims were rejected, for instance, when the challenged act was not attributable to the Iranian state. ${ }^{494}$ As Heiskanen recalls:

The adoption of the effects doctrine did not mean that the Tribunal automatically attributed all irregularities that occurred in Iran during the Islamic Revolution to the Government of Iran. The Tribunal stressed that the key issue in drawing the line between the deprivation of a property right and the materialization of a political risk was the atrributability of the loss to the Government; if the loss could not be attributed to the Government, there could be no liability. ${ }^{495}$

On this regard, the Iran-US CT followed the traditional requirements of state responsibility in international law, today included in Article 2 of the Articles on Responsibility of States for Internationally Wrongful Acts, adopted by the ILC in $2001 .^{496}$ Various failures of proof also prevented some claimants from obtaining a finding in their favour. ${ }^{497}$ In certain cases, they were not the owners of the allegedly taken properties. ${ }^{498}$ In others, the claimant retained some control over the property. ${ }^{499}$

${ }^{494}$ See Flexi-Van Leasing, Inc., v. The Government of the Islamic Republic of Iran, Iran-US CT, Award No. 259-36-1, 13 October, 1986, (1988) 12 Iran-US CTR 335.

${ }^{495}$ Heiskanen (2007), supra note 60 , at 224.

${ }^{496}$ According to this provision:

There is an internationally wrongful act of a State when conduct consisting of an action or omission:

(a) is attributable to the State under international law; and

(b) constitutes a breach of an international obligation of the State.

See note 23, supra.

On the question of attributability in the case-law of the Iran-US CT, see, in general, Brower, supra note 420, at 652-6; Pellonpää and Fitzmaurice, supra note 8, at 72-85; Aldrich, supra note 434, at 6045; Aldrich, supra note 420, at 197-200, \& 207-8; Brower and Brueschke, supra note 10, at 442-71; and Sedigh, supra note 8, at 666-76.

${ }^{497}$ See, e.g., Verney Rodney Pointon and Mary Lou Pointon v. The Government of the Islamic Republic of Iran, Iran-US CT, Award No. 516-322-1, 23 July, 1991, (1992) 27 Iran-US CTR 49.

${ }^{498}$ See Esahak Sabbonchian v. The Islamic Republic of Iran, Iran-US CT, Award No. 524-313-2, 15 November, 1991, (1992) 27 Iran-US CTR 248.

499 See Seismograph Service Corporation and Compagnie Française de Prospection Sismique $v$. National Iranian Oil Company and The Islamic Republic of Iran, Iran-US CT, Award No. 420-443-3, 31 March, 1989, (1990) 22 Iran-US CTR 3. 
The Iran-US CT sometimes awarded partial compensation under other measures affecting property rights in this type of situations. The tribunal further refused to find the Iranian state responsible for the taking of minority shareholders' property, as a consequence of the nationalisation of the majority shareholders' assets. ${ }^{500}$ A similar situation was found in relation with the nationalisation of the banking institutions in Iran. The mere assumption of control over these entities was not considered a taking of the funds in the respective bank accounts or an interference with the banking transactions normally provided by them. ${ }^{501}$ Exceptionally, the tribunal held the Iranian state responsible for a taking when it found that a specific measure adopted by the government-controlled bank had a serious deprivative impact on the claimant. ${ }^{502}$

Regarding the expropriatory effect of state regulations, the Iran-US CT declared in the interlocutory award of SEDCO that it is "an accepted principle of international law that a State is not liable for economic injury which is a consequence of bona fide 'regulation' within the accepted police powers of States". ${ }^{503}$ At first sight, this might seem a police-powers solution. However, in the same case the tribunal recognised that the duty to compensate will arise if this regulation damages the property to a "substantial or excessive degree". 504 This is a clear sole-effect approach. The only claim rejected by the Iran-US CT on grounds of police-powers was Emanuel Too. In this proceeding, an Iranian national owned an insured motel and restaurant in Turlock, California. In 1980 the motel-restaurant was destroyed by fire, the cause of which was identified as arson. Mr. Too contended that he had been the

\footnotetext{
${ }^{500}$ See Ataollah Golpira case, supra note 465.

${ }^{501}$ See William L. Pereira Associates case, supra note 478.

${ }^{502}$ Mouri, supra note 10 , at 147.

${ }^{503}$ SEDCO, Inc., and Sediran Drilling Company case, supra note 428, at 275.

${ }^{504} \mathrm{Ibid}$., note 25 at 275 .
} 
victim of "unknown prejudiced Americans", who had previously threatened him. ${ }^{505}$ The police and fire departments in Turlock investigated the incident without arriving to any final conclusions. The insurance company did not pay out the proceeds of the respective policy to the claimant, and the motel-restaurant was subject to a forced sale. The Internal Revenue Service of the US (IRS) sold at public auction a liquor permit held by Mr. Too and the proceeds were used to pay part of overdue employment taxes owed by the claimant. The claimant was also the owner of a coldstorage trailer found in the state of Arizona. The authorities of that state made efforts to inform Mr. Too of that fact and that there was an impeding auction for abandoned property. The claimant did not try to recover the trailer and it was sold at auction by the State of Arizona. Mr. Too argued that he had been wrongfully expropriated by the US. In a wording that reminds that of SEDCO, the Iran-US CT quoted the American Law Institute's Third Restatement of the Foreign Relations Law of the United States ${ }^{506}$, and declared that:

a State is not responsible for loss of property or for other economic disadvantage resulting from bona fide general taxation or any other action that is commonly accepted as within the police power of States, provided it is not discriminatory and is not designed to cause the alien to abandon the property to the State or to sell it at a distress price. ${ }^{507}$

According to the tribunal, the IRS' action was not aimed at Mr Too because he was an Iranian, nor was it "deliberately intended to cause him to abandon the property to the State or to sell it at a distress price". ${ }^{508}$ The action of the IRS was the result of Mr Too's failure to pay taxes withheld by him to his employees' salaries, and there is no state responsibility from a lawful levy for overdue taxes. As to cold-storage trailer

\footnotetext{
${ }^{505}$ Emanuel Too v. Greater Modesto Insurance Associates and the United States of America, Iran-US CT, Award No. 460-880-2, 29 December, 1989, (1991) 23 Iran-US CTR 378, at 379.

${ }^{506}$ See Chapter 6 infra.

${ }^{507}$ Emanuel Too case, supra note 505, at 387.

${ }^{508} \mathrm{Ibid}$. at $387-8$.
} 
left in Arizona, "[t]here is no question that the disposition of abandoned property is commonly accepted as a lawful action within the police powers of States, again provided that such a disposition does not discriminate against aliens". ${ }^{509}$ No taking was therefore found.

Exchange control restrictions were a problem related with that of state regulations. In several cases it was claimed that these measures constituted an expropriation. ${ }^{510}$ The Iran-UC CT did not preclude the possibility of characterising them as a taking, but subjected this determination to their harmony with the International Monetary Fund's Articles of Agreement. There was no award in which such harmony was not found. ${ }^{511}$

\subsection{Conditions of legality and their consequence}

The Iran-US CT recognised the three traditional requirements of a lawful taking: i.e., public purpose, non-discrimination, and compensation. Its jurisprudence, however, mostly did not support due process of law as an independent condition of legality. ${ }^{512}$ In any case, the tribunal judged the legality of an expropriation by reference to international law. ${ }^{513}$ In Amoco, the Iran-US CT declared that:

[c]onformity with domestic law is not usually cited as a condition for an internationally lawful nationalization, and the Treaty specifies no such condition. It is therefore doubtful whether it is one of the requisites of international law. The case law on this point is not very helpful. Violation of domestic law, when invoked, is

\footnotetext{
${ }^{509}$ Ibid., at 388 .

${ }^{510}$ See Hood Corporation v. The Islamic Republic of Iran, Bank Markazi Iran and Bank Mellat, IranUS CT, Award No. 142-100-3, July 13, 1984, (1986) 7 Iran-US CTR 36.

${ }^{511}$ Mouri, supra note 10 , at 148 .

512 See, in general, Pellonpää and Fitzmaurice, supra note 8, at 60-72; and Mouri, supra note 10, at 320-47.

${ }^{513}$ See Brower and Brueschke, supra note 10, at 502-3.
} 
most often analyzed as evidence of the lack of fulfilment of one of the conditions imposed by international law, such as the existence of a public purpose. ${ }^{514}$

The interpretation given by the tribunal to general interest and nondiscrimination clearly favoured the economic-sovereignty of the state. The national authorities' assertion that the expropriatory measure was adopted on the public purpose, on a non- discriminatory basis, created a strong presumption for the Iran-US CT that these conditions had been duly fulfilled. ${ }^{515}$ This wide margin of appreciation is similar to that given to the state in the case-law of the European Court of Human Rights concerning Article 1 of the First Optional Protocol. ${ }^{516}$ It was best illustrated in Amoco, where the Iran-US CT declared that:

[a] precise definition of the 'public purpose' for which an expropriation may be lawfully decided has neither been agreed upon in international law nor even suggested. It is clear that, as a result of the modern acceptance of the right to nationalize, this term is broadly interpreted, and that States, in practice, are granted extensive discretion. ${ }^{517}$

In fact, there was virtually no award in which a taking was found unlawful based specifically on the lack of this condition. ${ }^{518}$ For example, the Iran-US CT stated in the same case that the nationalisation of foreign investment, to obtain revenues from the exploitation of natural resources for the development of a country, "has not generally been denounced as unlawful and illegitimate". 519 This discretion of national authorities was not, however, considered absolute by the tribunal. Not only it expressly declared that a state has no right to expropriate a foreign investment only for financial purposes, but also considered a taking exclusively aimed at avoiding contractual obligations of the state -or of an entity controlled by it- to be unlawful

\footnotetext{
514 Amoco International Finance case, supra note 431, at 225.

${ }^{515}$ See, e.g., American International Group, Inc. case, supra note 439, at 105.

${ }^{516}$ See Chapter 3 supra.

${ }^{517}$ Amoco International Finance case, supra note 431, at 233.

${ }^{518}$ Mouri, supra note 10 , note 968 at 325.

${ }^{519}$ Amoco International Finance case, supra note 431, at 233.
} 
under international norms, as it would be contrary to the principle of good faith and to the "well-settled rule that a State has the right to commit itself by contract to foreign corporations". ${ }^{520}$ For this conclusion, the tribunal referred to Aminoil. ${ }^{521}$

\subsubsection{The effect or impact of the measure}

The state is liable to pay compensation for a taking. This duty is based on the loss or damages suffered by the foreign investor as result of the correspondent measure. Neither the doctrines of acquired rights, pacta sunt servanda or unjust enrichment were found by the Iran-US CT to constitute the basis of this obligation. Regarding this last theory, though, the tribunal declared in Sea-Land that it "is widely accepted as having been assimilated into the catalogue of general principles of law available to be applied by international tribunals", for:

The concept of unjust enrichment had its origins in Roman Law, where it emerged as an equitable device 'to cover those cases in which a general action for damages was not available'. It is codified or judicially recognised in the great majority of the municipal legal systems of the world $[\ldots] .{ }^{522}$

The Iran-US CT quoted the Lena Goldfields arbitration on the issue. ${ }^{523}$ According to Pellonpää and Fitzmaurice, non-payment did not render the expropriation illegal in the Iran-US CT's case-law, provided that some indication of it

\footnotetext{
${ }^{520}$ Ibid.

${ }^{521}$ American Independent Oil Co. (Aminoil) v. Kuwait, Reuter, Sultan, and Fitzmaurice, arbitrators, Award, 24 March 1982, (1982) 21 ILM 976.

${ }^{522}$ Sea-Land Service, Inc., $v$. The Government of the Islamic Republic of Iran and Ports and Shipping Organization, Iran-US CT, Award No 135-33-1, 22 June 1984, (1986) 6 Iran-US CTR 149, at 168.

${ }^{523}$ Lena Goldfields, Ltd. v. Union of Soviet Socialist Republics, Stutzer and Scott arbitrators, Award, 3 September 1930, reprinted in A Nussbaum, 'The Arbitration Between the Lena Goldfield's, Ltd. and the Soviet Government', (1950) Cornell LQ 31.

See, in general, Mouri, supra note 10, at 315-9.
} 
was made at the time of the taking. ${ }^{524}$ The tribunal adopted a sole-effect solution on the problem of intent, and generally found that worthy economic or social objectives motivating an expropriation did not exempt the host-state from the obligation to pay compensation. The tribunal was apparently influenced in this respect by the decisions of the Chorzow Factory case and the Norwegian Shipowners' claim. ${ }^{525}$ As Aldrich points out, Article II paragraph 1:

explicitly gave the Tribunal jurisdiction over claims that arouse out of both 'expropriations' and 'other measures affecting property rights', thereby suggesting clearly that neither the terminology nor the intent of actions attributable to either Government would affect the Tribunal's jurisdiction to award compensation if the actions had adversely affected a claimant's property rights. ${ }^{526}$

Already in 1983, he had declared in ITT that "[t]he intent of the government is less important than the effects of the measures on the owner, and the form of [these] measures $[\ldots]$ is less important than the reality of their impact". ${ }^{527}$ A couple of months later, the Iran-US CT recognised in Starrett that state measures rendering property-rights useless must be deemed expropriatory under international law, even though the state did not purport to have taken them. ${ }^{528}$ In 1984 , the tribunal came to the opposite conclusion in Sea-Land. The claimant was a US corporation engaged in international transportation by water of containerised cargo. Since 1978, Sea-Land encountered increasing difficulties in the continued use of a cargo facility built and operated by it in the port of Bandar Abbas, Iran, due to unexplained absence of government officials in charge of customs, immigration, health, etc. These difficulties led to the suspension and eventual termination of its operations. The Iran-US CT concluded that the country was in a state of upheaval following the 1979 revolution,

\footnotetext{
${ }^{524}$ Pellonpää and Fitzmaurice, supra note 8, at 70.

${ }^{525}$ See Mouri, supra note 10 , at 258-9.

${ }^{526}$ Aldrich, supra note 420, at 173.

${ }^{527}$ ITT Industries, Inc. case, supra note 480, Concurring Opinion of Judge Aldrich, at 352.

528 Starrett Housing Corporation, Starrett Systems, Inc., Starrett Housing International, Inc. case, supra note 426 , at 154 .
} 
and nothing suggested that the Iranian authorities had embarked on a policy of intentional disruption or non-cooperation with Sea-Land. According to the tribunal, a finding of expropriation would require, at the very least, a deliberate governmental interference with the foreign investor depriving it of the use and benefit of its investment. ${ }^{529}$ No intentional course of conduct directed against Sea-Land was found, and the expropriation claim was dismissed. The Iran-US CT referred its finding to Oscar Chinn. ${ }^{530}$ Judge Holtzmann disagreed with this conclusion and expressly declared that:

the critical question is the objective effect of a government's acts, not its subjective intentions. Acts by a government which have the effect of depriving an alien of his property are considered expropriatory in international law, whatever the government's intentions. ${ }^{531}$

The police-powers finding in Sea-Land obtained no support in subsequent awards. ${ }^{532}$ In TAMS, and Payne, the tribunal repeated the sole-effect statement of Judge Aldrich in ITT, i.e. that the intent of the government is less important than the effects of the measures on the owner, and that the form of the measures of control or interference is less important than the reality of their impact. ${ }^{533}$ Phillips was no exception. The Iran-US CT again declared that "a government's liability to compensate for expropriation of alien property does not depend on proof that the expropriation was intentional". ${ }^{534}$ The interlocutory award in SEDCO and the award in Phelps Dodge also reproduced Judge's Aldrich words. ${ }^{535}$ Phelps Dodge was a US corporation who had invested in an Iranian company established for the purpose of

\footnotetext{
${ }_{529}$ Sea-Land Service, Inc. case, supra note 522, at 166.

${ }^{530}$ Oscar Chinn case, supra note 425 , at 86.

${ }^{531}$ Sea-Land Service, Inc. case, supra note 522, Opinion of Judge Holtzmann, at 207.

${ }^{532}$ Aldrich, supra note 434, at 603; or Aldrich supra note 420, at 206-7.

${ }^{533}$ Tippets, Abbett, McCarthy, Stratton (TAMS) case, supra note 436, at 225-6; and Thomas Earl Payne case, supra note 430 , at 10-1.

${ }^{534}$ Phillips Petroleum Company Iran case, supra note 427, at 115.

${ }^{535}$ See SEDCO, Inc., and Sediran Drilling Company case, supra note 428, at 274-5; and Phelps Dodge Corp. and Overseas Private Investment Corp. case, supra note 467, at 130.
} 
manufacturing and selling various wire and cable products. During 1979 and 1980, there was a progressive erosion of the claimant's ability to exercise its ownership rights. At the end of 1980 , the management of the company was transferred to agencies of the Iranian government and the control of its factory was directly assumed by these authorities. The Iran-US CT found that Phelps Dodge was deprived of virtually all of the factory's value from this moment, and added:

The Tribunal fully understands the reasons why the Respondent felt compelled to protect its interests through this transfer of management, and the Tribunal understands the financial, economic and social concerns that inspired the law pursuant to which it acted, but those reasons and concerns cannot relieve the Respondent of the obligation to compensate Phelps Dodge for its loss. ${ }^{536}$

The Iran-US CT confirmed this view in Birnbaum. This case settled the claim of a US national who alleged to have been expropriated of his ownership interest in an Iranian architectural and engineering partnership (AFFA $)^{537}$, liquidated by the state of Iran. The tribunal found that the ownership interests of Mr. Birnbaum were taken on the date the provisional manager appointed by the Iran authorities effectively took control of the company. The Iran-US CT expressly declared that " $[\mathrm{t}]$ he Respondent's reasons and concerns for taking control of AFFA cannot relieve it from responsibility to compensate the Claimant for the taking", and that "a government cannot avoid liability for compensation by showing that its actions were taken legitimately pursuant to its own laws". 538

\footnotetext{
${ }^{536}$ Phelps Dodge Corp. and Overseas Private Investment Corp. case, supra note 467, at 130.

${ }^{537}$ Abdolaziz Farmanfarmaian \& Associates.

${ }^{538}$ Harold Birnbaum case, supra note 489, at 270.
} 


\subsubsection{Compensation and its standard}

In Phillips, the Iran-US CT held that the distinction between lawful and unlawful takings was relevant in relation to restitution as an available remedy for the affected claimant. ${ }^{539}$ The tribunal was, nevertheless, normally reluctant to grant restitution because it could not ensure specific performance. This reluctance also reflected, as Brower and Brueschke explain, "the customary practice that restitution is generally available only where the taking is found to be unlawful and the fact that the Tribunal $[\ldots]$ never found Iran's taking of American property to have been unlawful" ${ }^{540}$ The 1955 Iran-US Treaty of Amity, Economic Relations, and Consular Rights (Iran-US FCN) established the applicable standard of compensation for lawful takings of nationals of either country in the territory of the other. In a clear reference to the Hull Formula, Article IV paragraph 2 provided that the property of these nationals:

shall not be taken except for a public purpose, nor shall it be taken without the prompt payment of just compensation. Such compensation shall be in an effectively realizable form and shall represent the full equivalent of the property taken; and adequate provision shall have been made at or prior to the time of taking for the determination and payment thereof. ${ }^{541}$

The tribunal did not restrict its analysis to this treaty provision. Numerous awards and separate opinions of several judges also addressed the issue of the standard of compensation in customary international law. Westberg points out that one of the reasons for this situation was the Iranian challenge to the validity of the treaty in some early disputes:

\footnotetext{
${ }^{539}$ Phillips Petroleum Company Iran case, supra note 427, at 122.

${ }^{540}$ Brower and Brueschke, supra note 10, at 476-7.

541 Available at <http://www.parstimes.com/law/iran_us_treaty.html> (last visited 31 March, 2008).
} 
Choosing in these cases to avoid the question of the Treaty's status, the Tribunal ruled the question irrelevant on reasoning that the treaty provisions on compensation were synonymous with the requirements of customary international law. ${ }^{542}$

The first award to do so was ITT. Judge Aldrich's concurring opinion to this award concluded that the applicable rules of customary international law were not significantly different from those of the treaty: "[i]n either case, a taking of property must be accompanied by the prompt payment of just compensation which is effective and adequate to compensate fully for the value of the property taken". ${ }^{543}$ Judge Aldrich made express reference to the Norwegian Shipowners claim and Chorzow Factory case. His position was later confirmed by American International, TAMS, Phelps Dodge, SEDCO, Sola Tiles and Petrolane ${ }^{544}$. The standard of appropriate compensation was only applied exceptionally by the Iran-US CT in Ebrahimi. ${ }^{545}$ In spite of it, the tribunal awarded the claimants in this case an amount described by Aldrich as one that could reasonably be considered full compensation. ${ }^{546}$

The duty to pay compensation for both expropriations and nationalisations was expressly recognised in the INA case. In this award, the tribunal acknowledged that although nationalisations "are not per se unlawful", a lawful one would, nevertheless,

\footnotetext{
542 J Westberg, 'Compensation in Cases of Expropriation and Nationalization: Awards of the IranUnited States Claims Tribunal', (1990) 5/II ICSID Rev. 256, note 68 at 271.

${ }^{543}$ ITT Industries, Inc. case, supra note 480, Concurring Opinion of Judge Aldrich, at 354.

${ }^{544}$ See American International Group, Inc. and American Life Insurance Company case, supra note 439, at 102-6; Tippets, Abbett, McCarthy, Stratton (TAMS) case, supra note 436, at 225; Phelps Dodge Corp. and Overseas Private Investment Corp. case, supra note 467, at 132; SEDCO, Inc., v. National Iranian Oil Company, and The Islamic Republic of Iran, Second Iran-US CT, Interlocutory Award No ITL 59-129-3, 27 March, 1986, (1987) 10 Iran-US CTR 180, at 189; Sola Tiles, Inc. case, supra note 478, at 234-7; and Petrolane, Inc., Eastman Whipstock Manufacturing, Inc., and Seahorse Fleet, Inc. case, supra note 493, at 99.

${ }^{545}$ See Shanin Shain Ebrahimi, Cecilia Radene Ebrahimi and Christina Tandis Ebrahimi v. The Government of the Islamic Republic of Iran and National Iranian Oil Company, Iran-US CT, Award No. 560-44/46/47-3, 12 October, 1994, at paras. 88-98. Available at $<$ http://uk.westlaw.com/search/default.wl?rs=WLUK7.07\&fn= top\&sv=Split\&mt=ScotsLaw\&db=IN T-IRAN\&vr $=2.0 \& \mathrm{rp}=\% 2$ fsearch $\% 2$ fdefault.wl\&sp $=$ ukatedu- $000>$ (last visited 30 August, 2007).

${ }^{546}$ Aldrich, supra note 420 , at 238.

See, also, Wetsberg, supra note 424, at 15, \& 16-8; and Brower and Brueschke, supra note 10, at 536.
} 
also "impose on the government concerned the obligation to pay compensation". 547 The tribunal then applied the treaty standard, which it considered to be similar to that of customary international norms. The Iran-US CT went on to declare obiter that, regarding lawful large-scale nationalisations, international law had undergone a "gradual reappraisal, the effect of which may be to undermine the doctrinal value of any 'full' or 'adequate' (when used as identical to 'full') compensation standard", 548 This declaration triggered separate opinions by Judges Lagergren and Holtzmann. The former argued that international law recognised a flexible standard allowing for partial compensation in cases of large-scale nationalisations. The latter was emphatical in denying this change in the law. ${ }^{549} I N A$ 's approach was not followed by other decisions. ${ }^{550}$

According to the case-law of the Iran-US CT, the standard of full compensation was applicable not only for expropriations and nationalisations, but also for lawful and unlawful takings. Regarding expropriations that involved contract rights, the tribunal found that the valuation should also take into account the legitimate expectations of the foreign investor. ${ }^{551}$ Punitive damages were not awarded by the tribunal, not even when the expropriation was found not to be in conformity with customary international law. ${ }^{552}$ Before the establishment of the Iran-US CT, the

\footnotetext{
${ }^{547}$ INA Corporation, v. The Government of the Islamic Republic of Iran, Iran-US CT, Award No. 184161-1, 13 August, 1985, (1987) 8 Iran-US CTR 373, at 378.

${ }^{548}$ Ibid.

${ }^{549}$ See Westberg, supra note 542, at 273-5.

${ }^{550}$ See Brower and Brueschke, supra note 10, note 2326 at 491.

${ }^{551}$ See Mobil Oil Iran et al v. The Islamic Republic of Iran and The National Iranian Oil Company, Iran-US CT, Award No. 311-74/76/ 81/150-3, 14 July, 1987, (1988) 16 Iran-US CTR 3; and Phillips Petroleum Company Iran case, supra note 427. See, in general, Mouri, supra note 10, at 399-403.

${ }^{552}$ See, e.g., Amoco International Finance Corporation case, supra note 431, at 248.

See, also, Brower and Brueschke, supra note 10, at 477.
} 
award in Sapphire ${ }^{553}$ had already recognised the full compensation standard, comprising the loss suffered-damnum emergens- and the profit lost -lucrum cessans. ${ }^{554}$ The unrestricted application of this distinction has been criticised in doctrine, for the concepts of damnum emergens and lucrum cessans stem from the law of damages, and not from the law of expropriation. ${ }^{555}$ Amoco was the sole award of the Iran-US CT to depart from the otherwise uniformly applied principle of full compensation. In this case, the tribunal concluded that the taking was lawful and that the Iran-US FCN's requirement of compensation was applicable. Nevertheless, it sought the aid of customary rules for interpreting and implementing this condition and embarked on an extensive analysis of the Chorzow Factory case. The analysis led the Iran-US CT to conclude that compensation for a lawful taking includes damnum emergens -this is, the value of the expropriated property-, but not lucrum cessans -i.e. lost profits -, while an unlawful taking would require both. ${ }^{556}$

According to Pellonpää and Fitzmaurice, the tribunal equated damnum emergens to the going concern value of the company taken, with "a somewhat broad meaning, also encompassing elements (notably 'commercial prospects') which also might be argued to fall under lucrum cessans". ${ }^{557}$ In his concurring opinion to this award, Judge Brower considered the tribunal's finding to be "a misreading of Chorzow Factory and a misunderstanding of economics". He argued that the ICJ's case presented a simple scheme: lawful takings would entitle the claimant to damnum emergens and lucrum cessans, while unlawful expropriations to restitution of the

\footnotetext{
${ }^{553}$ This was an arbitration between a Canadian firm and the National Iranian Oil Company, regarding the nationalisation of Iran's oil industry in 1952.

${ }^{554}$ See Sapphire International Petroleum Ltd. v. National Iranian Oil Company, Cavin, sole arbitrator, Award, 15 March 1963, (1967) 35 ILR 136.

${ }^{555}$ Marboe, supra note 27, at 728 .

See Chapter 5 infra.

${ }_{557}^{556}$ See Amoco International Finance Corporation case, supra note 431, at 214, 222-4, 244, \& 246-52.

${ }^{557}$ Pellonpää and Fitzmaurice, supra note 8 , at 125.
} 
property taken or, if this is impossible or impracticable, to damages equal to damnum emergens and lucrum cessans, plus any consequential damages. ${ }^{558}$ The finding in Amoco was rejected implicitly in Starrett and explicitly in Phillips. ${ }^{559}$ In this last case, the tribunal expressly declared that the distinction between lawful and unlawful expropriation under customary international law, as evidenced in the Chorzow Factory case:

is relevant only to two possible issues: whether restitution of the property can be awarded and whether compensation can be awarded for any increase in the value of the property between the date of taking and the date of the judicial or arbitral decision awarding compensation. The Chorzow decision provides no basis for any assertion that a lawful taking requires less compensation than that which is equal to the value of the property on the date of taking. ${ }^{560}$

Full compensation was not applied, nonetheless, to those cases involving "other measures affecting property rights". The applicable standard in these proceedings was that established for lawful expropriations in Amoco. This is, damnum emergens, but not lucrum cessans. ${ }^{561}$ The different standard established for "other measures" allowed the Iran-US CT to find an interference with the foreign investor's right of property in those cases where its members were reluctant to grant the claimant a full compensation. As Aldrich explains, it was questionable:

whether either the Foremost or the Kodak award would have rejected liability for a taking or deprivation of property rights if the Claims Settlement Declaration had not permitted the Tribunal to give the claimants partial compensation under the guise of compensation for 'other measures affecting property rights'. ${ }^{562}$

He adds:

\footnotetext{
558 Amoco International Finance Corporation case, supra note 431, Concurring Opinion of Judge Brower, at 300-1.

559 See Starrett Housing Corporation, Starrett Systems, Inc., Starrett Housing International, Inc. case, supra note 427; and Phillips Petroleum Company Iran case, supra note 427.

See, also, Brower and Brueschke, supra note 10, at 506 \& 512.

See, also, Westberg, supra note 542, at 265-6.

${ }^{560}$ Phillips Petroleum Company Iran case, supra note 427, at 122.

${ }^{561}$ Mouri, supra note 10 , at 390.

${ }^{562}$ Aldrich, supra note 434 , at 591.
} 
Certainly, it was my impression that Judges Lagergren and Virally, the chairmen of the Tribunal chambers for Foremost and Kodak, respectively, generally sought what they considered to be equitable results and were not always comfortable with the full compensation standard that the 1955 Treaty of Amity between the United States and Iran made applicable to all takings of property rights. ${ }^{563}$

\subsection{Conclusion}

The Iran-US CT acknowledged the traditional international minimum standard of treatment in its application of the protection against expropriation and other measures affecting property rights established in its constitutive treaty. It is not unusual to find in the tribunal's decisions a reference to customary international law. It is also not unusual to find a reference to statements of international claims commissions, the PCIJ, arbitral tribunals and the ICJ in the area of expropriation of foreign property. The Iran-US CT recognised the three conditions for a lawful taking. The broad interpretation given to the requirements of public purpose and nondiscrimination gave host-states a wide margin of appreciation at the moment of adopting regulatory measures, similar to that enjoyed by the parties of the European Convention on Human Rights. Its assertion that the respective measure was adopted in the general interest of the national community, on a non-discriminatory basis, was a strong presumption for the Iran-US CT that these two conditions had been fulfilled. As to other measures affecting property rights, the tribunal considered this phrase to include not only measures within the scope of the concept of expropriation, but also other acts and omissions that seriously and unreasonably interfered with the property of an alien. Irreversible deprivative consequences, similar to those arising out of a taking were, nevertheless, generally required. The Iran-US CT supported its "other

\footnotetext{
${ }^{563} \mathrm{Ibid}$.
} 
measures" findings on the notion of lesser interferences found in Article 1 of the First Protocol to the European Convention on Human Rights.

Most of the cases brought before the Iran-US CT involved claims of creeping or constructive expropriations. This situation made difficult the determination of the date of the taking. The tribunal's solution consisted on establishing, on a case-by-case basis, the moment at which the interference had ripened into a more or less irreversible deprivation of property. A finding on expropriation also depended on the circumstances that surrounded the respective claim. The threshold applied by the tribunal was that of a non-ephemeral and unreasonable interference, depriving the owner of the effective use and control of his property. That is to say, the moment when the foreign investor's fundamental rights of ownership were rendered so useless that they must be deemed to have been taken. According to the tribunal, any expropriation, whether formal or informal, required the determination that a taking, transfer, or distribution of the property by the host state had occurred, and that the owner had been denied the use of its investment. In cases of expropriations of companies and business operations, these conditions were replaced by the host state's irreversible control of the respective entity and the deprivative consequences of this control over the property of the foreigner. Almost without exception, the Iran-US CT upheld the sole-effect rule and concluded that the intention of the state is less important than the consequence of the measure. National authorities are therefore liable to compensate an expropriated foreign investor whether the respective measure was motivated by worthy economic or social objectives or not. The tribunal exceptionally recognised a police-powers exception, but from a sole-effect perspective. It acknowledged that a state is not liable for economic injury as a 
consequence of bona fide regulation, within their accepted regulatory powers. However, if this regulation damages the alien's property to a substantial and excessive degree, then the host state will be responsible to pay compensation.

The Iran-US CT only distinguished lawful from unlawful takings concerning restitution as an applicable remedy. The term "just compensation", used in the IranUS FCN, was generally understood by the tribunal as equivalent to the full value of the expropriated property. The Iran-US CT found this standard of full compensation to be similar to that of customary international law, and was applied in a majority of the cases of expropriations and nationalisations, either lawful or unlawful. Aliens affected by other measures received a lower amount. This different standard enabled the tribunal to compensate a foreign investor for a lesser interference in those situations where the measure did not amount to a taking. 


\section{BILATERAL TREATIES AND INTERNATIONAL ARBITRATION}

A century before international human rights tribunals and the Iran-US CT dealt with expropriation claims, FCNs had already guaranteed the protection of US nationals investing abroad. By the end of the 1950s, another type of bilateral treaty came to replace them. More ambitious than FCNs in their scope of investment protection, and at the same time less exacting in their terms, BITs were at first only concluded between developed and developing countries that needed funds or materials to boost their economies. The change of attitude towards private property and foreign investment in former second-world countries and third-world states, led to the conclusion of BITs between developing countries, and between some developed states. The wide network of concluded BITs establish an international minimum standard, comprising the protection against takings, fair and equitable treatment, full protection and security, and most-favoured nation treatment, as well as national treatment. This network includes today even the reluctant Latin American countries, commonly associated with the Calvo doctrine, the principle of permanent sovereignty over natural resources, and the dated NIEO.

BITs follow the three traditional conditions of a lawful taking, i.e. public purpose, non-discrimination, and compensation. They also add a fourth requirement: due process of law. Property is called investment and is defined in BITs. This notion is important to the expropriation provision, for anything within its contours will be 
protected against it. Direct and indirect takings are mentioned, but not defined in BITs. The development of the concept of indirect expropriation is left to the case-law of international arbitral tribunals established under the dispute settlement provisions of these treaties. The awards of ad hoc and ICSID panels normally refer to other judicial decisions in the field of expropriation. The case-law of the Iran-US CT is frequently relied upon, as well as that of international arbitral panels established under the settlement provisions of investment codes and investment agreements. International human rights tribunals are also quoted, particularly the case-law on deprivations of property of the European Court. These awards have not only influenced the interpretation of BITs by international tribunals, but have also led to developments in treaty-law itself.

The investment protection in $\mathrm{FCNs}$, their failure, and the comparative success of BITs, are analysed in this chapter. It deals with the four requirements of a lawful expropriation in the latter, and addresses the interaction between the concepts of investment and indirect taking in them. The evolution of these concepts in recent BITs is also explained. The present chapter illustrates their interpretation and application by ad hoc and ICSID arbitral panels with references to several awards on indirect expropriation. Finally, it studies the evolution of the answers given to the threshold question in BIT arbitrations, focusing on the sole-effect and police-powers rules adopted in these judicial decisions. 


\subsection{Failure and success}

FCNs are the forerunners of BITs. ${ }^{564}$ International agreements of different titles are encompassed under this generic name. The 1785 Treaty of Amity and Commerce between Prussia and the US is an FCN. ${ }^{565}$ Another example is the 1955 Treaty of Amity, Economic Relations, and Consular Rights between Iran and the US. ${ }^{566}$ As these titles suggest, FCNs were mainly aimed at promoting trade and shipping, and only exceptionally included provisions protecting the property of aliens. This type of treaties was especially favoured by the US, which concluded FCNs in different waves since the $18^{\text {th }}$ century. ${ }^{567}$ Throughout almost two hundred years, it established a vast network of bilateral treaties, first with European and Latin American states, and later with countries of Asia and Africa.

The investment provisions in early FCNs were limited to an absolute standard of treatment that guaranteed the "special protection to the persons and property" 568 or "full and perfect protection for [...] persons and property" party. The first expropriation provisions in FCNs are already found in the late $19^{\text {th }}$

\footnotetext{
${ }^{564} \mathrm{See}$, in general, K Vandevelde, 'The Bilateral Investment Treaty Program of the United States', (1988) 21 Cornell ILJ 201, at 203-8; J Salacuse, 'BIT by BIT: The Growth of Bilateral Investment Treaties and Their Impact on Foreign Investment in Developing Countries', (1990) 24/III $I L$ 655, at 656-7; K Vandevelde, 'U.S. Bilateral Investment Treaties: the Second Wave', (1993) 14 Mich. JIL 621, at 624-5; Dolzer and Stevens, supra note 16, at 3-4; Guzman, supra note 223, at 652-3; D Blumemwitz, 'Treaties of Friendship, Commerce and Navigation', in R Bernhardt (ed.), EPIL (2000), Vol. IV; and Sornarajah, supra note 3, at 209-11.

${ }^{565}$ Available at <http://www.yale.edu/lawweb/avalon/diplomacy/germany/prus1785.htm> (last visited 31 March, 2008).

${ }_{566}^{56 e e}$ note 541, supra.

${ }^{567}$ Vandevelde (1988), supra note 564, at 204
}

The first FCN was the 1778 Treaty of Amity and Commerce between France and the US, available at <http://www.yale.edu/lawweb/avalon/diplomacy/france/fr1788-1.htm> (last visited 31 March, 2008).

${ }^{568}$ Art. XIII of the 1858 Treaty of Peace, Friendship, Commerce, and Navigation between Bolivia and the US, available at <http:/www.yale.edu/lawweb/avalon/diplomacy/bolivia/bolivia01.htm> (last visited 31 March, 2008).

${ }^{569}$ Art. IX, para. 3, of the 1859 Treaty of Friendship, Commerce, and Navigation between Paraguay and the US, available at $<\mathrm{http}$ :/www.marad.dot.gov/Programs/Treaties/Paraguay.html $>$ (last visited 31 March, 2008). 
century. They forbade the seizure of "vessels, cargoes, merchandise and effects", belonging to nationals of the other party, without payment of "equitable and sufficient compensation" ${ }^{570}$ In the first half of the $20^{\text {th }}$ century, FCNs expressly established the requirement of due process. ${ }^{571}$

After the Second World War, a new wave of FCNs were negotiated and concluded by the US. The protection of foreign investment was now the main objective, and a detailed takings provision guaranteeing prompt, adequate and effective compensation was included. ${ }^{572}$ This time, however, developing countries were reluctant to accept the international minimum standard requested by the US for its nationals.

\subsubsection{Ad-hoc investment treaties}

Parties to the General Agreement on Tariffs and Trade (GATT) adopted in 1955 the Resolution on International Investment for Economic Development, urging for the conclusion of bilateral treaties providing for its protection and security. ${ }^{573}$ Following this resolution, European countries started to negotiate and conclude a new type of international agreement, dealing exclusively with foreign investment: BITs. The

${ }^{570}$ Art. VIII of the 1870 General Treaty of Amity, Commerce, and Consular Privileges between El Salvador and the US; and Art. VIII of the 1846 General treaty of Peace, Amity, Navigation and Commerce between New Granada and the US, as quoted in Vandevelde (1988), supra note 564, at 205.

This guarantee was later broadened to property in general.

Ibid.

${ }^{571}$ See Art. I, para. 6, of the 1928 Treaty of Friendship, Commerce, and Consular Rights between Austria and the US.

${ }^{572}$ An $e . g$. of this new model was Art. IV paragraph 2 of the 1955 Iran-US FCN.

See Chapter 4 supra.

${ }^{573}$ L Loppacher and W Kerr, 'Investment Rules. The U.S. Agenda in Bilateral Trade Agreements', (2006) 7/I JWIT 39, at 45.

This area was not covered by GATT.

Guzman, supra note 223, at 653. 
theory of economic development behind BITs was different from that in FCNs. The latter relied on a simple view, summarised by Reisman and Sloane in these terms:

Merely put foreign investment into an underdeveloped economy, and, provided the host state refrains from expropriating the investment, it will generate a reasonable profit while the host state will experience the benefits of the multiplier effect. ${ }^{574}$

BITs require from the host-state much more than just refraining from taking the property of aliens. Their aim is to develop in capital-importing states the minimal administrative and legal framework that promotes and protects investment in capitalexporting countries. ${ }^{575}$ The success of BITs was gradual. The reason for this positive reception is not entirely clear. According to Salacuse:

it may lie in the fact that the European countries were less demanding than was the United States with respect to guarantees on such matters as free convertibility of local currency, abolition of performance requirements, and protection against expropriation. Moreover, the special relationship between European countries and their former colonies may have predisposed some newly independent nations to look favorably on concluding investment treaties with their previous colonial rulers. ${ }^{576}$

The good results of the European experience encouraged the US to launch its own BIT programme in $1977^{577}$. The last FCNs concluded by the US were the 1966 Treaties of Amity and Economic Relations with Togo, and Thailand. The first US BIT was that with Egypt, concluded in 1982. Today, BITs are one of the most important instruments for US investment abroad. ${ }^{578}$

The starting point of BITs are models, prototypes or draft treaties designed by a developed state, generally on the basis of the failed 1967 Draft Convention on the Protection of Foreign Property undertaken by the Organisation for Economic Co-

\footnotetext{
${ }^{574}$ Reisman and Sloane, supra note 41 , at 116.

${ }^{575}$ Ibid., 117-8.

576 Salacuse, supra note 564 , at 657.

577 See Vandevelde (1988), supra note 564, at 208-11; and Vandevelde (1993), supra note 564, at 6247.

${ }^{578}$ Loppacher and Kerr, supra note 573, at 46.
} 
operation and Development (OECD). ${ }^{579}$ This explains the homogeneity of BITs. A review of them confirms the regular assertion of most of their elements in standard terms. Besides takings, both the European and US models cover the same areas: admission, treatment, and dispute settlement. The US model contains, however, more detailed rules than the European version. Unlike the latter, the treatment provisions of the US model are not only applicable after the investment has been establishment; the pre-establishment phase of the investment is also covered. ${ }^{580}$ These differences are explained, in part, by the fact that the US version has included, since its first model, a mixture of provisions taken from modern FCNs and European BITs. ${ }^{581}$

The titles in most BITs openly declare a duality of purposes that illustrates the complementary interests of capital-exporting and capital-importing states: the reciprocal encouragement or promotion of investments, and their protection. ${ }^{582}$ The first objective was originally pursued by developing states. Since many third and former second-world countries had poor records concerning the respect of the right of private property, BITs were an unambiguous sign addressed to the international society revealing a crucial transformation of the respective state's policy towards

\footnotetext{
579 See Chapter 6 infra.

See, also, Salacuse, supra note 564, at 662-4; Dolzer and Stevens, supra note 16, at 1-3 \& 13; Sacerdoti, supra note 8, at 300-1; and P Juillard, 'MAI : A European View', (1998) 31 Corn. ILJ 477, at 477 .

The OECD is an international organisation with 30 member states "sharing a commitment to democratic government and the market economy".

See $<$ http://www.oecd.org $>$

${ }^{580}$ M-F Houde and C Yannaca-Small, 'Relationships between International Investment Agreements', in OECD, Working Papers on International Investment (2004), Nr. 1, at 4.

${ }^{581}$ See Vandevelde (1993), supra note 564, at 626.

${ }^{582}$ See, e.g., the 1968 Denmark-Indonesia BIT, called "Agreement concerning the encouragement and reciprocal protection of investments", available at

$<\mathrm{http}$ //www.unctad.org/sections/dite/iia/docs/bits/denmark_indonesia.pdf > (last visited 31 March, 2008);

and the 1994 Estonia-Israel BIT titled "Agreement [...] for the promotion and reciprocal protection of investments", available at <http://www.unctad.org/sections/dite/iia/docs/bits/estonia_israel.pdf $>$ (last visited 31 March, 2008).
} 
foreign investment. ${ }^{583}$ Whether this goal has been achieved in practice is open to question. ${ }^{584}$ The second purpose answered initially to the concerns of developed countries: protecting the foreign investor from eventual abuses by the host state in the exercise of its authority. An impartial device to settle controversies, as well as enforcement mechanisms for the treaty provisions, is an essential part of the protective purpose of BITs. Almost all of these international agreements have dispute settlement provisions regulating not only conflicts between the parties over the interpretation or application the respective treaty, but also those between the foreign investor and the host-state over the observance of its provisions, known as investment disputes.

BITs normally refer the conflicts between the investor and state to pre-existing arbitration rules, after a period of consultation between the parties. ${ }^{585}$ The majority of BITs make a reference to ICSID, an autonomous international organisation within the World Bank group that facilitates the settlement of investment disputes through conciliation and arbitration. The applicable procedural rules in these cases are those

\footnotetext{
583 Sornarajah, supra note 3 , at 214-5.
}

See, also, Dolzer and Stevens, supra note 16, at 12; V Been and J Beauvais, 'The Global Fifth Amendment: NAFTA's Investment Protection and the Misguided Quest for an International "Regulatory Takings" Doctrine', (2003) 78 NYU LR 30, at 118-20 \& 126; and Reisman and Sloane, supra note 41 , at 116 .

584 Some authors have concluded that BITs have little positive effect on the FDI that flows to developing countries:

See, e.g., J Tobin and S Rose-Ackerman, 'Foreign Direct Investment and the Business Environment in Developing Countries: the Impact of Bilateral Investment Treaties', (2004) 293 Yale Law and Economics Research Paper, available at <http://papers.ssrn.com/sol3/papers.cfm?abstract_id=557121> (last visited 31 March, 2008);

or J Tobin and S Rose-Ackerman, 'When BITs have some bite', (2006) Yale Law School Draft Working Paper, available at $<$ http://www.law.yale.edu/documents/pdf/When_BITs_Have_Some_Bite.doc $>$ (last visited 31 March, 2008).

See, also, Been and Beauvais, supra note 583, at 123-4.

Others are of the opinion that a higher number of BITs raises the FDI flows to developing countries:

See, e.g., E Neumayer and L Spess, 'Do Bilateral Investment Treaties Increase Foreign Direct Investment to Developing Countries? (2005) LSE Research Online, available at $<$ http://papers.ssrn.com/sol3/papers.cfm?abstract_id=616242> (last visited $31 \mathrm{March}, 2008$ ).

${ }^{585}$ Dolzer and Stevens, supra note 16 , at 119. 
contained in ICSID's constitutive treaty, the 1965 Washington Convention. ${ }^{586}$ Some BITs refer to arbitration under the rules of UNCITRAL, or to the Court of Arbitration of the International Chamber of Commerce (ICC) ${ }^{587} \mathrm{Ad}$ hoc arbitration is also a possibility in certain situations. ${ }^{588}$ The settlement mechanism for an investment dispute is available on the basis of the host-state's unilateral promise contained in an investment code, or most often in a $\mathrm{BIT}^{589}$, and not on its contractual relationship with the claimant. ${ }^{590}$ This is one of the biggest innovations in contemporary international law, but one that took some time before it was exercised by its main beneficiary, the foreign investor. ${ }^{591}$

Clear legal rules designed not only to supplant local legislation and institutions, but also to prevent controversial international customs to arise, are regularly included in BITs as part of their protective purpose. ${ }^{592}$ This objective has allowed capitalexporting states to counter unwanted trends in customary international law and guide

\footnotetext{
${ }^{586}$ An e.g. of this type of dispute settlement provision is Art. 8 of the 1990 France-Nigeria BIT, available in French at <http://www.unctad.org/sections/dite/iia/docs/bits/france_nigeria_fr.pdf $>$ (last visited 31 March, 2008).

See, also, Art. 9 of the 1994 Lithuania-The Netherlands BIT, available at $<$ http://www.unctad.org/sections/dite/iia/docs/bits/netherlands_lithuania.pdf > (last visited 31 March, 2008).

${ }^{587}$ Dolzer and Stevens, supra note 16 , at 129.

E.g. Art. 8 of the 1993 Ukraine-UK BIT, available at

<http://www.unctad.org/sections/dite/iia/docs/bits/uk_ukraine.pdf> (last visited 31 March, 2008).

See, also, Art. 9 of the 1999 Albania-Finland BIT, available at

$<$ http://www.unctad.org/sections/dite/iia/docs/bits/finland_albania_eng_fn.pdf $>$ (last visited 31 March, 2008);

or Art. 9 of the 2002 Bahrain-Thailand BIT, available at

$<$ http://www.unctad.org/sections/dite/iia/docs/bits/thailand_bahrain.pdf> (last visited 31 March, 2008).

${ }^{588}$ See, e.g., Annex B to the 1998 Australia-Lithuania BIT, available at

$<\mathrm{http} / /$ www.unctad.org/sections/dite/iia/docs/bits/australia_lithuania.pdf> (last visited 31 March, 2008).

${ }^{589}$ Or even in an EIA.

See Chapter 6 infra.

${ }^{590}$ See J Paulsson, 'Arbitration Without Privity", (1995) 10/II ICSID Rev. 232.

591 The first claim under the dispute settlement provisions of a BIT was only brought by one in 1987.

Redfern and Hunter, supra note 62, at 565.

See Asian Agricultural Products Ltd (AAPL) v. Republic of Sri Lanka, ICSID case No. ARB/87/3, Award, 27 June, 1990. Available at <http://ita.law.uvic.ca/documents/AsianAgriculture-Award.pdf $>$ (last visited 31 March, 2008).

${ }^{592}$ Salacuse, supra note 564 , at 661 .
} 
the interpretation of treaty provisions by arbitral panels. In the case of expropriation, one of the main objectives of the US programme was to oppose historical challenges to the Hull formula, which had gained momentum in the 1960 s and 1970 s. ${ }^{593}$ More recently, following the experience of NAFTA and recent BIT arbitrations, the new US model has expressly rejected the sole-effect rule, allowing those arbitral panels called to settle claims of indirect takings against the US to apply a wide policepowers exception.

This last situation illustrates the ironic fate of those treaties designed to protect the interests of nationals investing abroad. Notwithstanding the ultimate failure of FCNs and the success of BITs, both types of treaties share a common characteristic: unexpected consequences, in practice, for the interests of the capital-exporting state that supported their conclusion. For example, while an $\mathrm{FCN}$ allowed the US to exercise diplomatic protection on behalf of its nationals and bring an action against Italy before the ICJ in the ELSI case $\mathrm{S}^{594}$ and another one provided the standard of compensation under which the expropriation claims were assessed in the Iran-US $\mathrm{CT}^{595}$, the FCN with Japan helped this country to gain access to the internal market and basic exemptions in the US ${ }^{596}$, another one was the basis of an action brought against the US before the ICJ in the Nicaragua case ${ }^{597}$, and the FCN with Iran allowed the this country to bring a claim against the US before the ICJ in the Oil Platforms case. ${ }^{598}$ Concerning BITs, the same provisions designed to protect the investment of developed states in developing countries, have been used by foreign

\footnotetext{
${ }^{593}$ Vandevelde (1993), supra note 564, at 625.

${ }^{594}$ See Elettronica Sicula, S.p.A. (ELSI) case, supra note 12.

595 See Chapter 4 supra.

${ }^{596}$ Sornarajah, supra note 68 , at 57.

597 See Military and Paramilitary Activities In and Against Nicaragua (Nicaragua v. US), International Court of Justice, Judgment, 27 June 1986, (1986) 25 ILM 1023.

${ }^{598}$ See Oil Platforms (Iran v. US), International Court of Justice, Judgment, 6 November 2003, (2003) 42 ILM 1334.
} 
investors in the former to challenge the sovereign regulatory measures adopted by the respective host-state. ${ }^{599}$

\subsubsection{Lawful takings under BITs}

The protection against the expropriation of foreign property is the most important guarantee of BITs. All of them contain such a stipulation in a similar, if not identical, wording. ${ }^{600}$ A lawful taking is consistent with the treaty. Under BITs, it requires a public purpose, a non-discriminatory basis, the payment of compensation to the foreign investor, and due process of law. The first BIT ever concluded already considered these four conditions in its expropriation provision. ${ }^{601}$ The latest BIT models have not innovated on this issue. ${ }^{602}$ Unfortunately, this distinction between lawful and unlawful takings is rendered meaningless in practice, for both types of expropriation will receive the same standard of compensation. The Iran-US CT, for instance, generally did not differentiate between them at the moment of awarding compensation. ${ }^{603}$ Neither do BITs. The applicable standard is the Hull formula or similar ones, whether there is a breach of the treaty or not.

There is no definition of "public purpose" in international law. ${ }^{604}$ BITs refer to the first requirement of a lawful expropriation not only in these terms ${ }^{605}$, but also as

\footnotetext{
${ }^{599}$ Even nationals of developing countries have lodged claims against developed states.

See, e.g., Emilio Agustin Maffezini and The Kingdom of Spain, ICSID case No. ARB/97/7, Award, 13 November 2000, available at <http://ita.law.uvic.ca/documents/Maffezini-Award-English.pdf $>$ (last visited 31 March, 2008).

${ }^{600}$ Lowenfeld, supra note 102 , at 476.

${ }^{601}$ See Art. 3 para. 2 of the 1959 Germany-Pakistan BIT.

See, also, note 196, supra.

${ }^{602}$ See Art. 13 para. 1 of the 2006 Canada-Perú BIT, cited at note 51, supra.

${ }^{603}$ See Dinstein, supra note 8 , at 864. See, also, Chapter 4 supra.

${ }^{604}$ Dolzer and Stevens, supra note 16 , at 104.
} 
public "policy" ${ }^{\prime 606}$ or "interest". ${ }^{607}$ This condition is aimed at preventing the host state from adopting measures only for private reasons, not for the collective good. ${ }^{608}$ The prohibition of discrimination in case of expropriation is normally included in BITs with no further qualification. ${ }^{609}$ Both requirements may overlap at times -Mouri explains- since "a taking which is not for a public purpose is to some extent discriminatory" ${ }^{610}$ According to the Third Restatement, the discrimination prohibited by international law implies unreasonable distinction. ${ }^{611}$ This circumstance may be difficult to determine in practice. The crucial test will rest in the good faith of the state adoption the challenged measure. ${ }^{612}$ The rule on non-discrimination applied to expropriations forbids the state to take the property of nationals of a specific state or to give the deprived foreigner a differential treatment as to the procedure and the amount of compensation. ${ }^{613}$ The national and most-favoured-nation treatment (MFN) clauses in BITs, as well as the FET provision, reiterate this requirement of nondiscrimination. Dolzer and Stevens explain that the inclusion of this standard in the expropriation provision is "presumably justified by the assumption that the treatment

\footnotetext{
${ }^{605}$ See, e.g., Art. 5 para. 1 of the 1982 Cameroon-UK BIT, available at $<$ http://www.unctad.org/sections/dite/iia/docs/bits/uk_cameroun.pdf> (last visited 31 March, 2008). ${ }^{606}$ See, e.g., Art. 3 para. 2 of the 1978 Benin-Germany BIT, available at $<$ http://www.unctad.org/sections/dite/iia/docs/bits/germany benin.pdf> (last visited 31 March, 2008). ${ }^{607}$ See, e.g., Art 5 para. 1 of the 1982 Belgium-Sri Lanka BIT, available at $<$ http://www.unctad.org/sections/dite/iia/docs/bits/belg_lux_srilanka.pdf> (last visited 31 March, 2008).

${ }^{608}$ Dolzer and Stevens, supra note 16, at 105.

${ }^{609}$ Sacerdoti, supra note 8, at 389.

See, e.g., Art. 5 para. 2 of the 1993 Algeria-France BIT, cited at note 216, supra.

See, also, Art. 6 para. 1 of the 2004 Iceland-Lebanon BIT, available at

$<$ http://www.unctad.org/sections/dite/iia/docs/bits/lebanon_iceland.pdf> (last visited 31 March, 2008).

${ }^{610}$ Mouri, supra note 10, at 328.

${ }^{611}$ American Law Institute, supra note 51, at 200.

${ }^{612}$ A Maniruzzaman, 'Expropriation of Alien Property and the Principle of Non-Discrimination in International Law of Foreign Investment: An Overview', (1998) 8 JTLP 57, at 67.

${ }^{613}$ Sacerdoti, supra note 8 , at 388 .
} 
clauses refer to subsisting investments and that therefore these general clauses might no longer be applicable once an expropriatory measure has taken effect". ${ }^{614}$

The uncertainty on the standard of compensation in customary international law, derived from the long standing dispute between capital-exporting and capitalimporting states, led virtually all BITs to address the issue expressly. ${ }^{615}$ A majority of these treaties subscribe to the Hull formula. ${ }^{616}$ Almost all BITs concluded by Latin American states, for example, implicitly reject the "appropriate" standard by incorporating a provision that requires the payment of prompt, adequate or just and effective compensation in case of expropriation. ${ }^{617}$ The adoption of the Hull formula is done either by referring expressly to a "prompt, adequate and effective" compensation $^{618}$, by describing the compensation due in case of expropriation in conformance with the meaning of this set of words ${ }^{619}$, or by including a different formula -like, just compensation- accompanied by a specific method of valuation that makes it similar in practice to the former. ${ }^{620}$ There is no different standard for nationalisations and expropriations.

\footnotetext{
${ }^{614}$ Dolzer and Stevens, supra note 16 , at 106.

${ }^{615} \mathrm{Ibid}$., 108-9.

${ }^{616}$ See, e.g., Higgins, supra note 5, at 315; Dolzer and Stevens, supra note 16, at 97; Sacerdoti, supra note 8, at 395; Reisman and Sloane, supra note 41, at 135; and UNCTAD, supra note 19, at 245.

The non-binding 1992 World Bank Guidelines on the Treatment of Foreign Direct Investment, designed to complement BITs, provides for appropriate compensation, but then immediately adds that it will be deemed as such "if it is adequate, effective and prompt". Guideline IV, Sections 1 and 2, available at $<$ http://ita.law.uvic.ca/documents/WorldBank.pdf $>$ (last visited 31 March, 2008).

See Chapter 6 infra.

${ }^{617} \mathrm{See}$ A Escobar, 'Introductory Note on Bilateral Investment Treaties Recently Concluded by Latin American States', (1996) 11/I ICSID Rev. 86, at 90.

${ }^{618}$ See, e.g., Art. 5 para. 1 of the 1993 Finland-Korea BIT, available at

$<$ http://www.unctad.org/sections/dite/iia/docs/bits/korea_finland.pdf> (last visited 31 March, 2008).

See, also, Art. V para. 1 of the 1996 Chile-Ecuador BIT, available in Spanish at

<http://www.unctad.org/sections/dite/iia/docs/bits/chile_ecuador_sp.pdf> ( last visited 31 March, 2008).

${ }^{619}$ See, e.g., Art VI paras. 1 and 2 of the 1991 Hungary-Norway BIT, available at

$<$ http://www.unctad.org/sections/dite/iia/docs/bits/hungary_norway.pdf > (last visited 31 March, 2008).

${ }^{620}$ See, e.g., Art. 4 of the 1987 The Netherlands-Oman BIT, available at
} 
Prompt does not mean immediate, but it does mean with no deferment. This term is generally used in BITs to resolve disputes on the amount of the compensation. By adding this word, it is implied that interests are included in its payment and they accrue from the date of the taking ${ }^{621}$. Adequate is normally defined as "market" or "fair market" value before the expropriation took place. ${ }^{622}$ "Genuine" or "real" are usually considered to indicate the same standard. ${ }^{623}$ BITs hardly ever include an express regulation on the methods of calculation of this value. ${ }^{624}$ Not even last generation BITs regulate such methods expressly. ${ }^{625}$ Effective means in a form usable by the foreign investor, i.e. in a freely convertible currency with no restrictions regarding its transfer. ${ }^{626}$ In other words, the Hull standard requires the payment of the fair market value of the expropriated asset ("adequate"), speedily ("prompt"), and in a convertible currency ("effective"). ${ }^{627}$ The concept of due process derives from the

<http://www.unctad.org/sections/dite/iia/docs/bits/netherlands_oman.pdf> (last visited 31 March, 2008).

See Chapter 2 supra.

${ }^{621}$ Lowenfeld, supra note 102, at 481.

See Art. VI para. 2 of the 2000 Chile-Colombia BIT, available in Spanish at

<http://www.unctad.org/sections/dite/iia/docs/bits/chile_colombia_sp.pdf> ( last visited $31 \mathrm{March}$, 2008).

${ }^{622}$ See, e.g., Art. 6 para. 1 of the 2004 Uruguay-USA BIT, cited at note 51, supra.

${ }^{623}$ Redfern and Hunter, supra note 62, at 593.

${ }^{624}$ Dolzer and Stevens, supra note 16, at 110; and Sacerdoti, supra note 8, at 398.

For this reason, the 1992 World Bank Guidelines on the Treatment of Foreign Direct Investment suggests that for a going concern, with a proven record of profitability, the valuation should be made on the basis of the discounted cash flow value, used for establishing the present value of the expected future earnings of the business. For a non-going concern with lack of profitability, it should be made on the basis of the liquidation value. And for other assets, on the basis of the replacement value or the book value, in case such value has been recently assessed or has been determined as of the date of the taking. "Going concern", "discounted cash flow value", "liquidation value", "replacement value", and "book value" are all defined in this provision.

See Guideline IV, Section 6, cited at note 616, supra.

See, also, Chapter 6 infra.

${ }^{625}$ E.g., Art. 13 para. 2 of the 2006 Canada-Perú BIT only says that the "[v]aluation criteria shall include going concern value, asset value including declared tax value of tangible property, and other criteria, as appropriate, to determine fair market value".

See note 51, supra.

${ }^{626}$ Lowenfeld, supra note 102, at 482.

See, e.g., Art. 5 para. 1 of the 1997 Czech Republic-Ireland BIT, available at $<$ http://www.unctad.org/sections/dite/iia/docs/bits/czech_ireland.pdf> (last visited 31 March, 2008).

${ }^{627}$ Redfern and Hunter, supra note 62, at 589. 
Fifth and Fourteenth Amendments to the 1778 Constitution of the USA, and has a defined content only in US law. ${ }^{628}$ It is, nevertheless, used in the BITs of other countries as well. In fact, nearly all of these treaties include the requirement. ${ }^{629}$ Due process of law refers to the expropriation procedure, and indicates that the foreign investor has a right to prior notification and to a fair hearing before the taking occurs. ${ }^{630}$ Some BITs allude to expropriatory measures taken "under domestic legal procedures" or "in a legally established manner". ${ }^{631}$ Due process also suggests that the measure must be adopted by an unbiased official after a reasonable period of time. ${ }^{632}$ In some BITs, this requirement involves the availability of judicial review of the expropriatory measure. ${ }^{633}$

Against the background of a large number of homogenous treaties, the question of the influence of BITs on the customary law of expropriation has been asked several times. In doctrine, the positions range from those considering BITs to evidence international customs ${ }^{634}$, to those denying them any influence on the latter. ${ }^{635}$ The

See, also, Sacerdoti, supra note 33, at 123.

${ }^{628}$ G Fletcher and S Sheppard, American Law in a Global Context. The Basics (2005), 59-60; and UNCTAD (2004), 245.

${ }^{629}$ See, e.g., Art. 7 para 1 of the 1991 Australia-Vietnam BIT available at $<$ http://www.unctad.org/sections/dite/iia/docs/bits/australia_vietnam.pdf> (last visited 31 March, 2008).

See, also, Art. 5 para. 1 of the 1998 China-Swaziland BIT, available at

$<\mathrm{http}$ //www.unctad.org/sections/dite/iia/docs/bits/china_swaziland.pdf> (last visited 31 March, 2008).

${ }^{630}$ Dolzer and Stevens, supra note 16 , at 106.

631 See, e.g., Art. 6 para. 1 of the 1995 Norway-Perú BIT, available in Spanish at

$<$ http://www.unctad.org/sections/dite/iia/docs/bits/norway_peru_esp.pdf $>$ (last visited 31 March, 2008).

See, also, Art. 5 para. 1 of the 1998 Japan-Russia BIT, available at

$<$ http://www.unctad.org/sections/dite/iia/docs/bits/russia japan.pdf> (last visited 31 March, 2008).

${ }^{632}$ Dolzer and Stevens, supra note 16 , at 106.

${ }^{633}$ See, e.g., Art. 5 para 11975 Singapore-UK BIT, cited at note 199, supra.

See, also, Art. 5 para. 1 of the 1995 Denmark-Mongolia BIT, available at

<http://www.unctad.org/sections/dite/iia/docs/bits/denmark_mongolia.pdf> (last visited 31 March, 2008).

${ }^{634}$ See, e.g., Mann, supra note 9, at 249-50; Dolzer and Stevens, supra note 16, at 117; Brownlie, supra note 15, at 520; Lowenfeld, supra note, at 185, at 128; Lowenfeld, supra note 102, at 488; Reisman and Sloane, supra note 41 , note 158 at 150; S Hindelang, 'Bilateral Investment Treaties, Custom and a Healthy Investment Climate - The Question of Whether BITs Influence Customary 
geographical scope of BITs, comprising both developed and developing states, strongly supports the first of these views today. EIAs, widely concluded in the last years, corroborate this conclusion. ${ }^{636}$ It would seem that, in the long run, developed states were successful in confirming the Hull rule and preventing a new custom to arise, through state practice. At least in international investment law, the appropriate compensation standard is still relevant, for instance, in the case-law on nationalisations of the European Court of Human Rights. ${ }^{637}$

\subsection{Treaty law, judicial decisions}

The individual and social aspects of property are present in the interaction of the investment and the takings provisions in BITs. A measure may or may not amount to an expropriation, depending on how investment is defined. ${ }^{638}$ In other words, anything contained in this concept will be protected from direct and indirect takings. The notion of investment identifies the tangibles and intangibles to which the respective treaty applies. It also establishes the nature of the obligations created by it. ${ }^{639}$ BITs normally include a definition of investment followed by an open-ended list of examples that acknowledges the dynamic nature of this concept in international

International Law Revisited', (2004) 5/V JWIT 769, at 798-809; and J Salacuse and N Sullivan, 'Do BITs Really Work: An Evaluation of Bilateral Investment Treaties and Their Grand Bargain', (2005) 46/I Harv. ILJ 67, at 112-5.

${ }^{635}$ Kishaiyian, supra note 198, at 329 \& 372-375; Sacerdoti, supra note 8, at 395-7; Guzman, supra note 223 , at $643-4,666-9,678-80, \&$ 684-7; Sornarajah, supra note 3, at 205-6; and Cassese, supra note 71 , at 524-5.

${ }_{636}^{636}$ See Chapter 6 infra.

${ }^{637}$ See Chapter 3 supra.

${ }^{638}$ UNCTAD, supra note 19 , at 136.

${ }^{639}$ P Muchlinski, 'The Rise and Fall of the Multilateral Agreement on Investment: Where Now?', (2000) $34 I L$ 1033, at 1040; and UNCTAD, supra note 19, at 113. 
law. ${ }^{640}$ But it also creates uncertainty. For this reason, recent treaty models have included long and detailed lists of examples in their definitions ${ }^{641}$, and sometimes even an exhaustive list instead of a definition. ${ }^{642}$

BITs recognise, since the early 1960s, the well-accepted principle of international law that an expropriation may materialise in a direct or indirect form. ${ }^{643}$ Treaty-law often refers to takings as "expropriations" or "nationalisations". It also often describes them as state actions that have an "effect equivalent to" 644 or are "tantamount to" ${ }^{645}$ expropriation or nationalisation. These formulas give a hint on how to construe the respective treaty on the problem of intent. ${ }^{646}$ Occasionally, BITs refer to takings as "deprivations" or "dispossessions", of a "direct or indirect" character. ${ }^{647}$ None of these concepts is normally defined in the correspondent treaty. ${ }^{648}$ Last-generation BITs try to minimise this vagueness by outlining the expropriatory measures included in the correspondent provision. They also offer a

\footnotetext{
${ }^{640}$ Salacuse, supra note 634 , at 664. notion, giving BIT and EIA draftsmen a great degree of flexibility.

Redfern and Hunter, supra note 62, at 569.

${ }^{641}$ See, e.g., Art. 1 of the 2004 Uruguay-USA BIT, cited at note 51, supra.

${ }^{642}$ See, e.g. Art. 1 of the 2006 Canada-Perú BIT, cited at note 51, supra.

${ }^{643}$ Sacerdoti, supra note 8, at 382 .
}

The lack of a definition of investment in the 1965 Convention on the Settlement of Investment Disputes between States and Nationals of Other States also recognises the non-static character of this

See, e.g., Art. 3 of the 1961 Switzerland-Tunisia BIT, available in French at

$<\mathrm{http} / /$ www.unctad.org/sections/dite/iia/docs/bits/tunisia_switzerland_fr.pdf $>$ (last visited $31 \mathrm{March}$, 2008).

${ }^{644}$ See, e.g., Art. 6 of the 1988 Italy-Malaysia BIT, available in Italian at $<$ http://www.unctad.org/sections/dite/iia/docs/bits/italy_malasyia_it.pdf > (last visited 31 March, 2008) See, also, Art. 4 para. 2 of the 1997 Brazil-Cuba BIT, available in Portuguese at $<$ http://www.unctad.org/sections/dite/iia/docs/bits/Brazil cuba_por.pdf> (last visited 31 March, 2008). ${ }^{645}$ See, e.g., Art. 4 para. 2 of the 1981 Germany-Somalia BIT, available at $<$ http://www.unctad.org/sections/dite/iia/docs/bits/germany_somalia.pdf $>$ (last visited 31 March, 2008).

See, also, Art. 5 para. 1 of the 1997 Jordan-USA BIT, available at $<$ http://www.unctad.org/sections/dite/iia/docs/bits/us_jordan.pdf> (last visited 31 March, 2008).

${ }^{646}$ Kriebaum, supra note 35 , at 722 .

${ }^{647}$ See, e.g., Art. 4 of the 1987 Belgium-Malta BIT, available at $<$ http://www.unctad.org/sections/dite/iia/docs/bits/bel lux malta.pdf $>$ (last visited 31 March, 2008). See, also, Art. 4 para. 1 of the 1995 Albania-Sweden BIT, available at: $<$ http://www.unctad.org/sections/dite/iia/docs/bits/sweden_albania.pdf $>$ (last visited 31 March, 2008). ${ }^{648}$ Dolzer and Stevens, supra note 16 at 98. 
police-powers solution on the question of intent, different from the sole-effect one of former BITs. ${ }^{649}$

\subsubsection{The expropriation of investments}

Indirect or portfolio investment was not protected by customary international law in the past. Any risk related with it was regarded as commercial, leaving the alien as the sole responsible for the respective contingency. The situation was different for FDI. Potential interferences with it by the host state were considered political risks and received the protection of customary international law through the principles of state responsibility and diplomatic protection. ${ }^{650}$ Today, BITs cover both portfolio investment and FDI. The ideologically charged notion of property, rarely mentioned in the sources of international law, is now referred to as investment and defined in a large network of treaties.

The concept of investment can be found in those articles related with the scope of application of the respective BIT. A general definition is normally followed by a list of examples that includes movable and immovable property; interests in companies, such as shares, stocks and debentures; claims to money and titles to performance; intellectual property rights; and business concessions and similar rights. ${ }^{651}$ The fact that the definition of investment in BITs is broad does not imply

\footnotetext{
${ }^{649}$ See, e.g., Annex B.13 (1) of the 2006 Canada-Perú BIT, cited at note 51, supra.

See, also, Kriebaum, supra note 35, at 722-3.

${ }^{650}$ Sornarajah, supra note 3 , at 8.

${ }^{651}$ See Salacuse, supra note 634, at 664; Dolzer and Stevens, supra note 16, at 26; and Rubins, supra note 189 , at 292-3.

E.g. of such a provision include:

Art. 8 para. 1 of the 1966 Germany-Uganda BIT, available at
} 
that foreign investors have an absolute right of entry under these treaties. Many BITs limit the benefits of its provisions to investments approved by the state parties. ${ }^{652}$ Others specify that an investment is covered only if it is made in accordance with the laws and regulations of the host state. ${ }^{653} \mathrm{~A}$ further qualification refers to the moment when the investment was made. Recent treaties, however, offer protection to investments made after their entry into force, as well as those made before that time. ${ }^{654}$ The latest US BIT model, for example, uses an elaborate formula for its definition of investment. It comprises, among other things, a number of contracts and authorisations, so that the breach of these agreements or the withdrawal of these licenses or permits would constitute an expropriation. ${ }^{655}$ The same provision contains an explanatory footnote clarifying that the characterisation of licenses, permits or similar instruments as investments depends on the rights of the holder under domestic

<http://www.unctad.org/sections/dite/iia/docs/bits/germany_uganda_eng_gr.pdf > (last visited 31 March, 2008);

Art. 1 para. 3 of the 1973 Egypt-Switzerland BIT, available in French at $<$ http://www.unctad.org/sections/dite/iia/docs/bits/egypt_switzerland_fr.pdf> (last visited $31 \mathrm{March}$, 2008);

Art. 1 (a) of the 1976 Indonesia-UK BIT, available at

$<$ http://www.unctad.org/sections/dite/iia/docs/bits/uk_indonesia.pdf> (last visited 31 March, 2008); and Art. 1 para. 1 of the 1989 Bulgaria-France BIT, available in French at $<$ http://www.unctad.org/sections/dite/iia/docs/bits/france_bulgaria_fr.pdf $>$ (last visited 31 March, 2008).

Only exceptionally, BITs will cover FDI and not portfolio investment.

E.g., Art. 1 para. 1 of the 1991 Denmark-Poland BIT, after giving a general definition of investment and the correspondent exemplary list, adds that it:

shall refer $[\ldots]$ to all investments in companies made for the purpose of establishing lasting economic relations between the investor and the company and giving the investor the possibility of exercising significant influence on the management of the company concerned.

Available at $<$ http://www.unctad.org/sections/dite/iia/docs/bits/denmark_poland.pdf $>$ (last visited 31 March, 2008).

${ }^{652}$ See, e.g., Art. 1 para. 3 of the 1971 Malaysia-Netherlands BIT, available at $<$ http://www.unctad.org/sections/dite/iia/docs/bits/netherlands_malaysia.pdf $>$ (last visited $31 \mathrm{March}$, 2008).

${ }^{653}$ See, e.g., Art. 1 para. 1 of the 1991 China-Czech Republic BIT, available at $<$ http://www.unctad.org/sections/dite/iia/docs/bits/czech_china.pdf> (last visited 31 March, 2008).

${ }^{654}$ Dolzer and Stevens, supra note 16, at 45-6.

See, e.g., Art. 1 para. 1 of the 1994 Italy-Lithuania BIT, available in Italian at <http://www.unctad.org/sections/dite/iia/docs/bits/italy_lituania_it.pdf> (last visited 31 March, 2008). ${ }^{655}$ See Art. 1 of the 2004 Uruguay-USA BIT, cited at note 51, supra. 
law. ${ }^{656}$ This and other declarations are the result of the abundant case-law on investment disputes. ${ }^{657}$

The tests applied by international tribunals to determine that the indirect taking of an investment has occurred are inconsistent. The severity of the impact on owner's property, the degree of interference, and the intention of the governmental action coexist uneasily in the case-law on expropriation. ${ }^{658}$ The severity of the impact and the degree of interference are related. The former refers to the ability of the foreign investor to use, enjoy, and dispose his property. ${ }^{659}$ The latter, excludes mere restrictions on this ability. ${ }^{660}$ In general, arbitral panels established under investment codes, investment agreements and BITs have applied the substantial interference standard, i.e. the destruction of such ability. ${ }^{661}$ ICSID tribunals, for example, have required the total dispossession of at least one of the patrimonial attributes of property, to consider a measure or group of measures challenged to amount to an indirect expropriation. ${ }^{662}$ As Kriebaum points out: "[t]he investor need not be deprived of its physical property, but it has to be deprived of the economic benefit of its investment". ${ }^{663}$ Normally, international arbitral panels will focus on the effect of the respective measure and not on the intent of the government behind its adoption. ${ }^{664}$

\footnotetext{
${ }^{656}$ Note 3 to Art. 1 of the 2004 Uruguay-USA BIT, cited at note 51, supra.

${ }^{657}$ The cumulative number of treaty-based investor-to-state claims, including NAFTA arbitrations, was 219 by November 2005. 132 have been brought before ICSID tribunals and 87 before other arbitral panels.

UNCTAD, supra note 214 , at 1-2.

${ }^{658}$ See Gutbrod and Hindelang, supra note 51, at 63-6.

${ }^{659}$ Ibid., 63.

${ }^{660}$ Madalena, supra note 62 , at 78.

${ }^{661}$ U Kriebaum, 'Partial Expropriation', (2007) 8/I JWIT 69, at 69-72.

${ }^{662}$ Kunoy, supra note 95 , at 485.

Even if they have delayed effects.

Ibid., 487.

${ }^{663}$ Kriebaum, supra note 661 , at 71.

${ }^{664}$ See, e.g., Kunoy, supra note 95, at 469.
} 

arbitrations.

The uncertainties surrounding the indirect expropriation of foreign investments, particularly the potential and actual application of the sole-effect rule on investments in the US, has led the national authorities of this country to add the following declaration in an annex to its latest BIT model:

1. [The takings provision] is intended to reflect customary international law concerning the obligation of States with respect to expropriation.

2. An action or a series of actions by a Party cannot constitute an expropriation unless it interferes with a tangible or intangible property right or property interest in an investment.

3. [The takings provision] addresses two situations. The first is known as direct expropriation, where an investment is nationalized or otherwise directly expropriated through formal transfer of title or outright seizure.

4. The second situation addressed by [the takings provision] is known as indirect expropriation, where an action or series of actions by a Party has an effect equivalent to direct expropriation without formal transfer of title or outright seizure.

(a) The determination of whether an action or series of actions by a Party, in a specific fact situation, constitutes an indirect expropriation, requires a case-by-case, fact-based inquiry that considers, among other factors:

(i) the economic impact of the government action, although the fact that an action or series of actions by a Party has an adverse effect on the economic value of an investment, standing alone, does not establish that an indirect expropriation has occurred;

(ii) the extent to which the government action interferes with distinct, reasonable investment-backed expectations; and

(iii) the character of the government action.

(b) Except in rare circumstances, non-discriminatory regulatory actions by a Party that are designed and applied to protect legitimate public welfare objectives, such as public health, safety, and the environment, do not constitute indirect expropriations. ${ }^{65}$

This annex confirms the broad concept of property and tries to avoid the debate that arose in NAFTA arbitrations in relation to the meaning of measures "tantamount to nationalization or expropriation". ${ }^{666}$ The relation between the takings provision and customary international law is aimed at more conservative interpretations by arbitral panels. Most importantly, the annex gives the international standard of treatment a

\footnotetext{
${ }^{665}$ Annex B of the 2004 Uruguay-USA BIT, cited at note 51, supra.

${ }^{666}$ See Chapter 6 infra.
} 
particular national content: that developed in the US regulatory takings doctrine. It names the three factors put forward by the US Supreme Court in the Penn Central case for the determination of an indirect expropriation. ${ }^{667}$ This is, the economic impact of the measure, the interference with the investor's legitimate expectations, and the character of the governmental action. Even though the US model refers to the economic impact of the measure, it expressly rejects a sole-effect solution. In fact, it openly adopts a police-powers exception for non-discriminatory regulatory measures aimed at public purposes, which can easily be interpreted as a police-powers rule. ${ }^{668}$ The latest Canadian model follows the US approach in similar terms, but not the new British, Mexican and Spanish versions. ${ }^{669}$

Articles 12 and 13 of the US BIT, paragraphs 2 and 3, respectively, should be read in relation to the police-powers rule contained in its Annex B. They declare that nothing in this treaty shall be construed to prevent the contracting parties from adopting, maintaining, or enforcing any measure otherwise consistent with its provisions, which they consider appropriate to ensure that the investment activity in their territory is undertaken in a manner sensitive to environmental or labour concerns. The footnote in Article 1, providing that "[t]he term "investment" does not include an order or judgment entered in a judicial or administrative action" also follows the US regulatory takings doctrine, where judicial decisions cannot constitute expropriation. $^{670}$

\footnotetext{
${ }^{667}$ See Chapter 6 infra.

${ }^{668}$ Fortier and Drymer, supra note 8 , at 318-9.

${ }^{669}$ See Arts. 10 and 11, and Annex B.13 (1) of the 2006 Canada-Perú BIT, cited at note 51, supra. See, also, International Institute for Sustainable Development, Investment Treaty News, 16 May, 2006, available at <http://www.iisd.org/pdf/2006/itn_may16_2006.pdf> (last visited $31 \mathrm{March,2008);} \mathrm{and}$ International Institute for Sustainable Development, Investment Treaty News, 2 November, 2006, available at <http://www.iisd.org/pdf/2006/itn_nov2_2006.pdf> (last visited 31 March, 2008); referring to the 2006 Mexico-UK BIT; and the 2006 Mexico-Spain BIT.

${ }^{670}$ Note 4 to Art. 1 of the 2004 Uruguay-USA BIT, cited at note 51, supra.
} 


\subsubsection{Some claims before arbitral panels}

Investment disputes generally confirm the customary minimum standard of treatment which protects aliens from expropriation. Following the case-law of the PCIJ, the European Court of Human Rights, and the Iran-US CT, these awards adopt a traditional definition of property, including tangibles as well as intangibles. ${ }^{671}$ Both actions and omissions can lead to a finding of indirect expropriation. This view is consistent with that of the 2001 ILC's Articles on State Responsibility. ${ }^{672}$ Early international arbitrations based on the settlement provisions of investment agreements concluded between the host-state and the alien illustrate the interaction of a broad concept of property and that of indirect taking. Benvenuti et Bonfant, for instance, refers to a series actions and omissions of the Congolese authorities considered in 1980 to have the cumulative effect of a de facto expropriation of an Italian investor. ${ }^{673}$ In Biloune, the investment involved the development of a hotel resort complex in the city of Accra, Ghana, by the joint venture of a Syrian national and a governmental entity. The work was well advanced when state officials issued an order to stop it. According to them, a building permit was lacking. The authorities demolished part of the complex, and the foreign investor was arrested, held in

\footnotetext{
See note 51, supra.

See, also, Been and Beauvais, supra note 583, at 79.

${ }^{671}$ See Chapters 3 \& 4 supra.

${ }^{672}$ See Crawford, supra note 24 , at 77.

Olguin is a rare example in which the tribunal refused to recognise omissions as constitutive of indirect expropriation.

Eudoro Armando Olguin v. Republic of Paraguay, ICSID Case No. ARB/98/5, Award, 26 July 2001, para. 84, available in Spanish at <http://ita.law.uvic.ca/documents/Olguin-award-sp.pdf $>$ (last visited 31 March, 2008).

${ }^{673}$ See Ltd. Benvenuti et Bonfant srl, v. The Government of the People's Republic of the Congo, ICSID Case No. ARB/77/2, Award, 8 August 1980, (1982) 21 ILM 740.
} 
custody without charge, deported from Ghana, and not allowed to return. The site was closed and the project remained uncompleted. Mr. Biloune claimed damages for the taking, denial of justice, and violation of human rights. The tribunal decided that it only had jurisdiction over the controversy which the parties had agreed to submit to arbitration. This is, the investment dispute. In relation to the alleged lack of permit, the panel concluded that though the letter of the law supported the contention that the work could not go forward without it, the practice with regard to this site indicated an exception to this rule. ${ }^{674}$ Concerning the conjunction of the stop work order, the demolition, the arrest, the detention, and the deportation of Mr. Biloune without the possibility of re-entry, the tribunal concluded that these measures prevented the foreign investor from pursuing an approved project, thus constituting a constructive expropriation of the foreign investor's contractual rights on it and, accordingly, the taking of the value of his interest in the joint venture. ${ }^{675}$

Recent cases have relied on the minimum standard of treatment as well. A BIT arbitration concluded in 2000 that the physical seizure of the assets of a British investor, by an Egyptian public company, amounted to a de facto expropriation. Quoting $T A M S^{676}$, the arbitral panel in Wena Hotels found Egypt responsible for the "non-ephemeral" deprivation of the alien's "fundamental rights of ownership" derived from this seizure. ${ }^{677}$ The tribunal agreed with $A m c o$ 's assertion that "a case of expropriation exists not only when a state takes over private property, but also when the expropriating state transfers ownership to another legal or natural person", and

${ }^{674}$ Biloune and Marine Drive Complex Ltd v. Ghana Investments Centre and the Government of Ghana, UNCITRAL arbitration, Award on Jurisdiction and Liability, 27 October 1989, (1994) 95 ILR 183 , at 208 .

${ }^{675}$ Ibid., 209.

${ }^{676}$ See Chapter 4 supra.

${ }^{677}$ Wena Hotels Ltd. v. Arab Republic of Egypt, ICSID case No. ARB/98/4, Award, 8 December 2000, (2002) 41 ILM 896, at 914-5, paras. 98-101. 
that a taking "also exists merely by the state withdrawing the protection of its courts from the owner expropriated, and tacitly allowing a de facto possessor to remain in possession of the thing seized". ${ }^{678}$

Transfer of property to the state adopting the measure has not been considered a necessary condition for finding an indirect taking. However, its appropriation constitutes prima facie proof of an expropriation. ${ }^{679}$ Olguin and Lauder are exceptions to the general trend on transfer of property in indirect takings. ${ }^{680}$ This last arbitration and $C M E$ were settled in 2001 with only days of difference. Both tribunals described indirect expropriation as measures that do not involve an overt taking, but effectively neutralise the benefit or enjoyment of the alien's property. ${ }^{681}$ Each panel reached, however, opposed findings over the same facts, on the basis of different interpretations of the concept of property. In Lauder no taking was found. The panel came to this conclusion by applying a restrictive view of the rights attached to property. ${ }^{682}$ Conversely, the notion of investment invoked by the tribunal in $C M E$ was very broad. It included the income producing potential of property rights. ${ }^{683}$ From this perspective, the destruction of the commercial value of the investment was equated to

${ }^{678}$ Ibid., 914, para. 97.

In Amco, however, the revocation of an investment license was not considered a taking, but a breach of a sui generis legal relationship -comparable to a contract- between the alien and Indonesia. The arbitral panel found a violation by the host state of a principle similar to that of pacta sunt servanda in international law, on one hand, and of the respect due for the acquired rights of the US investor, derived from that legal relationship, on the other. The proceedings in Amco where instituted under the relevant settlement provision of an investment agreement between the foreign investor and the hoststate, and the relevant provision of an investment code of the Indonesia.

See Amco Asia Corporation et al v. The Republic of Indonesia, ICSID case No. ARB/81/1, Award, 21 November 1984, (1985) 24 ILM 1022, at 1030, \& 1033-5, especially paras. 189, $244 \& 248$.

${ }^{679}$ Newcombe, supra note 50 , at 8 .

${ }^{680}$ See Eudoro Armando Olguin case, supra note 672, para. 84; and Ronald S. Lauder v. The Czech Republic, UNCITRAL arbitration, Award, 3 September, 2001, para. 203, available at $<$ http://ita.law.uvic.ca/documents/LauderAward.pdf> (last visited 31 March, 2008).

${ }^{681}$ See Ronald S. Lauder case, supra note 680, paras. 200-1.

See, also, CME Czech Republic B.V. v. The Czech Republic, UNCITRAL arbitration, Partial Award, 13 September 2001, para. 604, available at

$<$ http://ita.law.uvic.ca/documents/CME-2001PartialAward.pdf> (last visited 31 March, 2008).

${ }^{682}$ Paulsson and Douglas, supra note 8, at 150.

${ }^{683} \mathrm{Ibid}$. 
its deprivation. Paulsson and Douglas explain that CME's solution is normally favoured in investment disputes, exposing "the limitations of a purely legal or formalistic concept of property [common in direct takings case-law] that is not sensitive to the economic rights or expectations associated with the property". ${ }^{684}$

Another BIT arbitration where an indirect taking was found is Middle East Cement. This case referred to a de facto revocation of a license by Egypt, and the seizure and auction of a ship, among other claims. A Greek investor was allowed by decree to import, and store cement in a quay near the El-Abadia Port in Suez, as well as to pack and dispatch it within the country. After some years, the authorities prohibited by another decree certain imports of cement, directly affecting the alien's activity. The applicable BIT mentioned "business concessions conferred by law or under contract" within its definition of investment. The tribunal had no doubt that licenses were included in this phrase ${ }^{685}$, and had no problems in finding that the measure adopted by Egypt deprived the foreign investor of the use and benefit of its investment, even though it retained nominal ownership of the respective rights. ${ }^{686}$ Egypt was also found responsible for the administrative seizure and auction of a ship of the Greek investor, after the enactment of the decree that tacitly revoked its license. These measures were considered in 2002 by the tribunal to have effects "tantamount to expropriation" ${ }^{687}$ The other claims of the Greek investor were rejected.

\footnotetext{
${ }^{684}$ Ibid., 152-3.

${ }^{685}$ Middle East Cement Shipping and Handling Co. v. Arab Republic of Egypt, ICSID case No. ARB/99/6, Award, 12 April 2002, paras. 100-1, available at $<$ http://ita.law.uvic.ca/documents/MECement-award.pdf> (last visited 31 March, 2008).

${ }^{686} \mathrm{Ibid}$. , para. 107.

${ }^{687} \mathrm{Ibid}$, para. 144.
} 


\subsection{The question of intent}

Most judicial decisions of ad hoc and ICSID panels follow the sole-effect rule, awarding compensation for the effective deprivation of the foreign investor. Hoststates enjoy a wide margin of appreciation in this case-law, similar to that recognised by the European Court of Human Rights and the Iran-US CT. ${ }^{688}$ Arbitral panels will normally refrain from challenging the motives of national authorities. Goetz, for instance, stated that in the absence of manifest error, an international tribunal should not substitute its own judgment for the host state's discretionary evaluation of the public purpose involved in the adoption of a particular measure. ${ }^{69}$ The panel in this BIT-based arbitration concluded that the revocation of the French national's free zone benefits by the government of Burundi completely deprived the claimant of the utility of his investment, thus amounting to a measure having an effect similar to a taking. ${ }^{690}$

Contradictions on this issue, however, are not uncommon. They appear even within a single judicial decision. Biloune expressly declared in 1989 that " $[\mathrm{t}] \mathrm{he}$ motivations for the actions and omissions of Ghanaian governmental authorities are not clear[,] [b]ut the Tribunal need not establish those motivations to come to a conclusion in the case". ${ }^{691}$ After a few lines, the same ad hoc panel implicitly refuted its sole-effect approach by recognising a police-powers rule in the form of a broad exception worded in these terms:

such prevention of [the foreign investor] from pursuing its approved project would constitute constructive expropriation of [the alien's] contractual rights in the project

\footnotetext{
${ }^{688}$ See Chapters 3 \& 4 supra.

${ }^{69}$ Antoine Goetz et consorts c. Republique du Burundi, Affaire CIRDI ARB/95/3, Sentence, 10 February 1999, para. 126, available in French at $<$ http://ita.law.uvic.ca/documents/Goetz-Award.pdf> (last visited 31 March, 2008). ${ }^{690}$ Ibid., para. 124.

${ }^{691}$ Biloune and Marine Drive Complex Ltd case, supra note 674, at 209.
} 
and, accordingly, the expropriation of the value of Mr Biloune's interest in [the company], unless the Respondents can establish by persuasive evidence sufficient justification for these events. ${ }^{692}$

Recently, international tribunals established under BITs have shown a certain inclination to asses the public purpose claimed by the host-state adopting the challenged regulatory measure. This tendency reflects the debate in the context of NAFTA, following a number of claims lodged against the US. It also jeopardises the dominance of the sole-effect rule in ad hoc and ICSID panels.

\subsubsection{Exceptions to an approach}

$S P P$ is an early example of the application of a sole-effect solution to an expropriation claim. The investment in this case involved the development of tourist complexes: one at the Pyramids area near Cairo, and another at Ras El Hekma, on the Mediterranean coast of Egypt. The foreign investor was a Hong Kong corporation, owning a joint venture with the Egyptian authorities, incorporated for the purpose of developing the projects. The Pyramids project encountered political opposition in Egypt, on the grounds that it posed a threat to undiscovered antiquities. As a result of a series of governmental decrees and resolutions, the Pyramids project was cancelled. SPP initiated an arbitration before the ICC, relying on the dispute settlement clause of the investment agreement concluded with the host state. The tribunal established Egypt's obligation to pay compensation to the claimant. The Egyptian authorities appealed the ICC award to the French Cour d'Appel, which annulled it for jurisdictional reasons. SPP then commenced arbitral proceedings under the

${ }^{692}$ Ibid. 
Washington Convention relying on the dispute settlement provision of the Egyptian

investment code. In the award issued in 1992, the tribunal recognised that the hoststate's cancellation of the project to protect antiquities "constituted a lawful exercise of the right of eminent domain". ${ }^{693}$ Nevertheless -it added-, the rules of Egyptian and international law governing the exercise of this right impose an obligation to indemnify those affected by it. An obligation that "applies equally where antiquities are involved". ${ }^{694}$ The panel quoted the Chorzow Factory case, and the judgments in Amoco and Phillips ${ }^{695}$, for rejecting the argument of the respondent that expropriation applies only to real property rights. SPP was granted compensation for the taking of its contractual rights in the joint venture as a consequence of the cancellation by the Egyptian authorities of the Pyramids project. ${ }^{696}$

The clearest statement of the sole-effect rule is found in one of the few arbitrations dealing in recent years with a direct expropriation claim: Santa Elena. In it, the tribunal made the following declaration: ${ }^{697}$

While an expropriation or taking for environmental reasons may be classified as a taking for a public purpose, and thus may be legitimate, the fact that the Property was taken for this reason does not affect either the nature or the measure of the compensation to be paid for the taking. That is, the purpose of protecting the environment for which the Property was taken does not alter the legal character of the taking for which adequate compensation must be paid. The international source of the obligation to protect the environment makes no difference.

Expropriatory environmental measures -no matter how laudable and beneficial to society as a whole- are, in this respect, similar to any other expropriatory measures that a state may take in order to implement its policies: where property is expropriated, even for environmental purposes, whether domestic or international, the state's obligation to pay compensation remains. ${ }^{698}$

\footnotetext{
${ }^{693}$ Southern Pacific Properties (Middle East) Limited (SPP) v. Arab Republic of Egypt, ICSID Case No. ARB/84/3, Award, 20 May 1992, (1993) 32 ILM 933, para. 158.

${ }^{694}$ Ibid., para. 159.

${ }^{695}$ See Chapter 4 supra.

${ }^{696}$ Southern Pacific Properties (Middle East) Limited (SPP) case, supra note 693, paras. 164, 169 \& 172.

${ }^{697}$ This case was not based in a BIT and the dispute referred to the amount of compensation paid by Costa Rica to the US investor.

${ }^{698}$ Compañia del Desarrollo de Santa Elena S.A. case, supra note 39, para. 71.
} 
The tribunal referred to TAMS in support of this view. ${ }^{699}$ It also said that:

[a] decree which heralds a process of administrative and judicial considerations of the issue in a manner that effectively freezes or blights the possibility for the owner reasonably to exploit the economic potential of the property, can, if the process thus triggered is not carried out within a reasonable time, properly be identified as the actual act of taking. ${ }^{700}$

A year later, the ad hoc panel in CME expressly acknowledged the policepowers exception to the sole-effect rule of the Convention Establishing the Multilateral Investment Guarantee Agency (MIGA). ${ }^{701}$ According to it, nondiscriminatory measures of general application, which governments normally take for the purpose of regulating economic activity in their territories, do not constitute a taking. ${ }^{702}$ Then, in 2003, Generation Ukraine quoted TAMS and Santa Elena with approval. ${ }^{703}$ This award expressly stated that the intent of the government is less important than the effects of the measures on the owner, and that the form of the measures of control or interference is less important than the reality of their impact. ${ }^{704}$ Predictability and the respect for legitimate expectations were stressed as elements of the protection against expropriation. ${ }^{705}$ That same year, another ICSID panel initially endorsed the sole-effect rule, only to implicitly refute it later.

TECMED involved a Spanish investor that bought a controlled landfill of hazardous industrial waste in Mexico and was granted a renewable license to operate it by the local authorities. The Mexican state later rejected the alien's application for renewal, and requested the closure of the landfill. This resolution moved the foreign investor to institute arbitral proceedings under the applicable BIT. The tribunal started

\footnotetext{
${ }^{699}$ Ibid., para. 77.

${ }^{700} \mathrm{Ibid}$., para. 76.

${ }^{701}$ See Chapter 6 infra.

${ }^{702}$ CME Czech Republic B.V. case, supra note 691, para. 321.

${ }^{703}$ Generation Ukraine, Inc. case, supra note 46, paras. 20.24-5.

${ }^{704}$ Ibid., paras. $20.23 \& 20.25$.

${ }^{705}$ Ibid., paras. $20.29,20.37 \& 23$.
}

No taking was found in this case. 
its analysis of the expropriation claim from the standpoint of the sole-effect doctrine. Quoting Metalclad ${ }^{706}$, the arbitral panel understood takings to materialise "through actions or conduct, which do not explicitly express the purpose of depriving one of rights or assets, but actually have that effect" ${ }^{707}$ To establish whether the resolution is a measure equivalent to an expropriation under the terms of the BIT -the tribunal said-, it should be first determined that the claimant was, due to this resolution, "radically deprived of the economical use and enjoyment of its investments, as if the rights related thereto - such as the income or benefits related to the Landfill or to its exploitation- had ceased to exist". ${ }^{708}$ According to the panel:

This determination is important because it is one of the main elements to distinguish, from the point of view of an international tribunal, between a regulatory measure, which is an ordinary expression of the exercise of the state's police power that entails a decrease in assets or rights, and a de facto expropriation that deprives those assets and rights of any real substance. ${ }^{709}$

The panel found support for this view in the wording of the BIT, covering expropriations, nationalisations or "any other measure with similar characteristics or effects". ${ }^{710}$ With quotes on the case-law of the Inter-American Court of Human Rights, the European Court of Human Rights and the Iran US CT -which included Ivcher $^{711}$, Matos ${ }^{712}$, TAMS and Phelps Dodge ${ }^{713}$-, the panel reasoned that in an indirect taking claim the decision-maker should not restrict itself to the evaluation of

\footnotetext{
${ }^{706}$ See Chapter 6 infra.

707 Técnicas Medioambientales TECMED S.A. v. The United Mexican Status, ICSID case No. ARB (AF)/00/2, Award, 29 May, 2003, paras. 113-4, available at $<\mathrm{http}$ ///ita.law.uvic.ca/documents/Tecnicas_001.pdf> (last visited 31 March, 2008).

${ }^{708}$ Ibid., para. 115.

The tribunal referred to Pope \& Talbot and the Third Restatement on this point.

See Chapter 6 infra

${ }^{709}$ Técnicas Medioambientales TECMED S.A. , case, supra note 707, para. 115.

${ }^{710}$ Ibid.

${ }^{711}$ See Chapter 3 supra.

${ }^{712}$ See ibid.

${ }^{713}$ See Chapter 4 supra.
} 
whether a formal dispossession occurred, but should look beyond mere appearances

and determine the reality behind the situation that was denounced, for:

it is understood that the measures adopted by a State, whether regulatory or not, are an indirect de facto expropriation if they are irreversible and permanent and if the assets or rights subject to such measure have been affected in such a way that '....any form of exploitation thereof...' has disappeared; i.e. the economic value of the use, enjoyment or disposition of the assets or rights affected by the administrative action or decision have been neutralized or destroyed. Under international law, the owner is also deprived of property where the use or enjoyment of benefits related thereto is exacted or interfered with to a similar extent, even where legal ownership over the assets in question is not affected, and so long as the deprivation is not temporary. The government's intention is less important than the effects of the measures on the owner of the assets or on the benefits arising from such assets affected by the measures; and the form of the deprivation measure is less important than its actual effects. $^{714}$

The arbitral panel in TECMED concluded that the measure adopted by Mexico fulfilled these characteristics. Surprisingly, it then decided to approach the claim from a police-powers perspective, using the fair balance test developed by the European Court, and at least two of the three factors of the US Penn Central case for this purpose. $^{715}$ The tribunal declared that a state measure is expropriatory if it has a negative financial impact and is proportional to the public interest protected. ${ }^{716}$ It recognised that due deference is owed to the host-state's definition and implementation of its public policy. The panel considered, however, that this circumstance did not prevent it from establishing whether such measures were reasonable "with respect to their goals, the deprivation of economic rights and the legitimate expectations of who suffered such deprivation". ${ }^{717}$ Only the third factor of the Penn Central case was missing from this assessment, i.e. the character of the governmental action. In a direct reference to the case-law of the European Court, the

\footnotetext{
${ }_{714}^{71}$ Técnicas Medioambientales TECMED S.A. , case, supra note 707, para. 116.

${ }^{715}$ See Chapter 3 supra and Chapter 6 infra.

See, also Newcombe, supra note 50, at 17-20.

${ }^{716}$ Técnicas Medioambientales TECMED S.A. , case, supra note 707, para. 122.

${ }^{717}$ Ibid.
} 
tribunal added that there must be a balance between the charge or weight imposed on the foreign investor and the aim sought to be realized by the conduct of the state, and "[t]o value such charge or weight, it is very important to measure the size of the ownership deprivation caused by the actions of the state and whether such deprivation was compensated or not". ${ }^{718}$ The panel reviewed the motives of the resolution -that is to say, its public purpose- not to determine if it was legally issued, but to establish if the BIT was violated. It concluded that the measure was adopted solely on political considerations. $^{719}$ No justification for the resolution was found, and compensation was awarded for the taking to the foreign investor. ${ }^{720}$

\subsubsection{Conforming a trend?}

The standard of substantial interference, as required in the Pope \& Talbot case, was upheld in Occidental, an UNCITRAL arbitration settling an investment dispute in 2004. The tribunal concluded that "there has been no deprivation of the use or reasonably expected economic benefit of the investment, let alone measures affecting a significant part of the investment". ${ }^{721}$ The ICSID panel in CMS rejected a claim of expropriation in 2005 from the standpoint of the sole-effect approach advanced in TAMS, Metalclad and CME. Quoting Lauder, the CMS award defined

\footnotetext{
${ }^{718} \mathrm{Ibid}$.

The tribunal quoted profusely from the case-law of the European Court for this purpose. Matos, Mellacher, Pressos Compania Naviera, and James were mentioned in its decision.

See Chapter 3 supra.

${ }^{719}$ Técnicas Medioambientales TECMED S.A. , case, supra note 707, paras. 129-32, 139, 144-5, \& 148.

${ }^{720}$ Ibid., para. 151.

${ }^{721}$ Occidental Exploration and Production Co. (OEPC) v. The Republic of Ecuador, UNCITRAL arbitration, Award, 1 July 2004, para. 89, available at

$<$ http://ita.law.uvic.ca/documents/Oxy-EcuadorFinalAward_001.pdf> (last visited 31 March, 2008).
} 
indirect taking as measures that do not involve an overt expropriation, but that effectively neutralise the enjoyment of the property. ${ }^{722}$ The standard applied in this case was that of substantial deprivation, as developed in Pope \& Talbot. ${ }^{723}$ No such deprivation was found by the tribunal, persuaded by Argentina's argument that after the measures adopted in response to the financial crisis in the country, the US investor retained the full ownership and control of its investment. ${ }^{724}$

That year, an ad hoc tribunal held that certain acts and omissions of the Polish authorities did amount to a deprivation of the claimant's investment. Eureko referred to the failed privatisation of a wholly state-owned insurance company. The panel considered that, though the Dutch investor was not deprived of its shares in the company or of its dividends, the refusal of the authorities to conduct the agreed public offering of shares was discriminatory and in blunt violation of its expectations. ${ }^{725}$ TECMED, Metalclad ${ }^{726}$, and CME were mentioned in support for the arbitral panel's finding that the contractual rights of Eureko were indirectly deprived by the host state in breach of the Netherlands/Poland BIT. ${ }^{727}$ The question of intent was directly, though controversially, addressed in Saluka. This BIT arbitration endorsed in 2006 the police-powers solution adopted months before in Methanex. ${ }^{728}$ The panel expressly declared that:

\footnotetext{
${ }^{722}$ CMS Gas Transmission Company v. Republic of Argentina, ICSID case No. ARB/01/8, Award, 12 May, 2005, para. 261, available at <http://ita.law.uvic.ca/documents/CMS_FinalAward_000.pdf > (last visited 31 March, 2008).

${ }^{723} \mathrm{Ibid}$., para. 263.

See Chapter 6 infra.

${ }^{724}$ CMS Gas Transmission Company case, supra note 722, para. 263.

${ }^{725}$ Eureko B.V. v. Republic of Poland, Ad hoc arbitration, Partial Award, 19 August, 2005, para. 241, available at <http://ita.law.uvic.ca/documents/Eureko-PartialAwardandDissentingOpinion.pdf $>$ (last visited 31 March, 2008).

See ibid., para. 242.

${ }^{726}$ See Chapter 6 infra.

${ }^{727}$ Eureko B.V. case, supra note 725 , paras. 241 \& 243.

${ }^{728}$ See Chapter 6 infra.
} 
It is now established in international law that States are not liable to pay compensation to a foreign investor when, in the normal exercise of their regulatory powers, they adopt in a non-discriminatory manner bona fide regulations that are aimed at the general welfare. ${ }^{729}$

In other words, "certain takings or deprivations are non-compensable", ${ }^{730}$

According to this tribunal, international law has yet to draw:

a bright and easily distinguishable line between non-compensable regulations on the one hand and, on the other, measures that have the effect of depriving foreign investors of their investment and are thus unlawful and compensable in international law. ${ }^{731}$

Saluka's solution forgets that compensation is a requirement of a lawful taking, not just a consequence of the breach of an international obligation. The panel reached such a conclusion, even though the provision of the applicable BIT was worded on the traditional terms of the international law of expropriation, establishing the four conditions for a lawful taking: public purpose, non-discrimination, payment of compensation, and due process. ${ }^{732}$ Without further reasoning, the tribunal in Saluka decided that the Czech Republic had not crossed the line that separates permissible regulatory action from expropriation. As a result, the host-state was not held responsible for breaching the treaty. ${ }^{733}$ This view has not been followed in later BIT arbitrations.

Months after Saluka, two tribunals adopted TECMED's solution. In Azurix, the panel complemented the sole-effect rule with the proportionality and the legitimate expectations principles. ${ }^{734} L G \& E$ confirmed the applicability of the fair balance test

\footnotetext{
${ }^{729}$ Saluka Investments BV v. The Czech Republic, UNCITRAL arbitration, Partial Award, 17 March, 2006, para. 255, available at <http://ita.law.uvic.ca/documents/Saluka-PartialawardFinal.pdf $>$ (last visited 31 March, 2008).

${ }^{730}$ Ibid., para. 258.

${ }^{731} \mathrm{Ibid}$, para. 263.

${ }^{732}$ See ibid., para. 245.

${ }^{733}$ Ibid., para. 265.

${ }^{734}$ Azurix Corp. v. The Argentine Republic, ICSID case No. ARB/01/12, Award, 14 July, 2006, paras. 310-2, available at <http://ita.law.uvic.ca/documents/AzurixAwardJuly2006.pdf> (last visited 31 March, 2008).
} 
to investment arbitrations. ${ }^{735}$ No taking was found in any of these two BIT cases. ${ }^{736}$ The tribunal in Telenor openly avoided giving its view on the problem of intent, and concluded that it lacked jurisdiction on the basis of the standard of substantial deprivation. ${ }^{737}$ The award of this BIT arbitration, however, expressly declared that to answer the threshold question "the determinative factors are the intensity and duration of the economic deprivation suffered by the investor as the result of them". ${ }^{738} \mathrm{~A}$ month later, the arbitral panel in $A D C$ awarded compensation to the claimant for the breach by the host-state of the requirements of a lawful taking. The claimants in this case were companies incorporated in Cyprus, chosen in a tender process by the Hungarian authorities to expand and operate the Budapest international airport. After the renovation and construction work was over, the host state decided to change its national aviation strategy. All the foreign investor's operations and related activities in the airport were taken over effectively by a state entity, acting under a decree issued by the governmental authorities.

$A D C$ declared that a just compensation in case of deprivation is within the legitimate and reasonable expectations of a foreign investor. In a rather uncommon approach in investment disputes, the panel then decided to asses the requirement of public purpose claimed by Hungary. The tribunal reasoned that this condition requires some proven genuine general interest, for the mere reference to public purpose does

\footnotetext{
${ }^{735}$ LG\&E Energy Corp., LG\&E Capital Corp., LG\&E International Inc. V. Argentine Republic, ICSID case No. ARB/02/1, Decision on liability, 3 October, 2006, paras. 189 \& 194-5, available at $<\mathrm{http} / /$ ita.law.uvic.ca/documents/ARB021_LGE-Decision-on-Liability-en.pdf> (last visited 31 March, 2008).

${ }^{736}$ Azurix Corp. case, supra note 734, para. 322; and LG\&E Energy Corp., LG\&E Capital Corp., LG\&E International Inc. case, supra note 735, paras. 198-200.

${ }^{737}$ Telenor Mobile Communications A.S. v. The Republic of Hungary, ICSID case No. ARB/04/15, Award, 13 September 2006, paras. 65-7 \& 79-80, available at $<$ http://ita.law.uvic.ca/documents/Telenorv.HungaryAward_001.pdf> (last visited 31 March, 2008).

${ }^{738} \mathrm{Ibid}$., para. 70.
} 
not "magically put such interest into existence". ${ }^{739}$ No public purpose appeared from the conduct of the Hungarian authorities. Furthermore, no due process of law was found in their conduct. For these reasons, compensation was awarded in favour of the foreign investor. In 2007, another BIT-based panel approached the requirement of public purpose in the same way as $A D C$, followed the sole-effect rule, and found an indirect taking. Siemens involved a German investor in Argentina. ${ }^{740}$ The claimant won a bidding process for the provision of an immigration control, personal identification and electoral information system. A contract was subsequently awarded and approved by decree for these purposes. The agreement came into effect and production of national identity cards started, after some postponement not attributable to the foreign investor. The Argentinian authorities detected a problem in some of the cards printed and suspended their production and distribution. The investor was prohibited from introducing any modification to correct this problem and a new contract was agreed between the parties. An economic-financial emergency law was then enacted and the government gave the foreign investor a new non-negotiable draft proposal, with different terms from that of the formerly agreed document. The original contract was finally terminated by decree in conformity with this law, and the investor initiated arbitration proceedings under the Argentina-Germany BIT.

The tribunal in Siemens considered the contract to be included in the definition of investment of the treaty. It further concluded that there was an interference in the execution of the contract through governmental action that amounted to a creeping

\footnotetext{
${ }^{739}$ ADC Affiliate Limited and ADC \& ADMC Management Limited $v$. The Republic of Hungary, ICSID case No. ARB/03/16, Award, 2 October, 2006, para. 423, available at

$<$ http://ita.law.uvic.ca/documents/ADCvHungaryAward.pdf> (last visited 31 March, 2008).

Particularly damaging on Hungary's plea of public purpose was its subsequent privatisation of the airport, acquired by a company not related with the foreign investor.

${ }_{740}$ Siemens was the fourth award against Argentina in 18 months.

See International Institute for Sustainable Development, Investment Treaty News, 19 February, 2007, available at $<\mathrm{http}: / / \mathrm{www}$.iisd.org/investment/itn/archive.asp $>$ (last visited 31 March, 2008).
} 
expropriation, in its "effect and permanence" $"$ "741 The tribunal quoted the Norwegian

Shipowners 's claim and confirmed the traditional sole-effect rule by recalling:

that Article 4(2) refers to measures that "a sus efectos" (in its Spanish original) would be equivalent to expropriation or nationalization. The Treaty refers to measures that have the effect of an expropriation; it does not refer to the intent of the State to expropriate. [...] A different matter is the purpose of the expropriation, but that is one of the requirements for determining whether the expropriation is in accordance with the terms of the Treaty and not for determining whether an expropriation has occurred. $^{742}$

The panel analysed the public purpose claimed by the Argentinian authorities and found no such requirement in the uncompensated measures adopted by it, described in the award as "an exercise of public authority to reduce the costs to Argentina of the Contract recently awarded through public competitive bidding, and as part of a change of policy by a new Administration eager to distance itself from its predecessor", 743

Compañia de Aguas del Aconquija returned to a more traditional approach on the problem of indirect takings later on that year. This BIT-based arbitration was related to a concession agreement which unsuccessfully privatised the water and sewage services of the Province of Tucumán. The panel found Argentina responsible for expropriating the French investor. This award quoted profusely the case-law of the Iran-US CT, other BIT arbitrations, and NAFTA panels to support its choice on the problems of the degree of interference and of the motives behind it. Regarding the former, the tribunal said:

it is not infrequent in cases of indirect expropriation that the investor suffers a substantial deprivation of value of its investment. Numerous tribunals have looked at the diminution of the value of the investment to determine whether the contested measure is expropriatory. The weight of authority [...] appears to draw a

\footnotetext{
${ }^{741}$ Siemens A.G. v. The Argentine Republic, ICSID case No. ARB/02/8, Award, 6 February, 2007, paras. 253, 260, $267 \& 271$, available at <http://ita.law.uvic.ca/documents/Siemens-ArgentinaAward.pdf $>$ (last visited 31 March, 2008).

${ }^{742} \mathrm{Ibid}$., para. 270.

${ }^{743}$ Ibid., para. 273.
} 
distinction between only a partial deprivation of value (not an expropriation) and a complete or near complete deprivation of value (expropriation). ${ }^{744}$

On the question of intent, Compañia de Aguas del Aconquija adopted the soleeffect rule, as found in TAMS, Phillips, Pope \& Talbot, and Metalclad:

There is extensive authority for the proposition that the state's intent, or its subjective motives are at most a secondary consideration. While intent will weigh in favour of showing a measure to be expropriatory, it is not a requirement, because the effect of the measure on the investor, not the state's intent, is the critical factor. $[\ldots]$

Also, the structure of Article 5(2) of the Treaty directs the Tribunal first to consider whether the challenged measures are expropriatory, and only then to ask whether they can comply with certain conditions, ie public purpose, non-discriminatory, specific commitments, et cetera. If we conclude that the challenged measures are expropriatory, there will be violation of Article 5(2) of the Treaty, even if the measures might be for a public purpose and non-discriminatory, because no compensation has been paid. ${ }^{745}$

\subsection{Conclusion}

BITs have transformed the protection of foreign investment into one of the most active fields of international-law making of the last decades. Countries in the Americas, Africa, Asia, Europe and Oceania have concluded these treaties, most of which are in force, embracing the international minimum standard described in them. The extent of state practice is such, that the taking provisions in BITs can be fairly considered to evidence customary international law. The dispute settlement clauses have allowed international arbitral panels to add some flesh to the bony descriptions of indirect expropriation in treaty-law. These clauses have enabled foreign investors in developing countries to challenge state measures that interfere with their property.

\footnotetext{
${ }^{744}$ Compañia de Aguas del Aconquija S.A. and Vivendi Universal S.A. v. Argentine Republic (Vivendi II), ICSID case No. ARB/97/3, Award, 20 August, 2007, para. 7.5.11, available at $<$ http://ita.law.uvic.ca/documents/VivendiAwardEnglish.pdf> (last visited 31 March, 2008). See, also, ibid., paras. 7.5.24, 7.5.30. \& 7.5.34.

${ }^{745} \mathrm{Ibid}$., paras. 7.5.20-1.
} 
They have even enabled foreign investors in developed states to do so. For this reason, last-generation US and Canadian BIT models have been modified to influence the interpretation of international tribunals settling claims of indirect expropriation against these contracting parties.

BITs and the case-law on investment disputes of ad hoc and ICSID panels adopt a broad concept of property. These tribunals have applied various tests to establish when the conduct of a state amounts to an indirect taking. Their awards focus on the severity of its impact in the foreign investment, the degree of the interference, or the intention of the host-state. Arbitral panels will normally require a substantial interference, effectively and permanently depriving the foreign investor of the use, enjoyment and disposition of his property. This deprivation can be the result of either actions and omissions of the host-state, or both. Generation Ukraine, TECMED, Occidental, Eureko, and $A D C$ highlight the important role of the legitimate expectations of the foreign investor in that determination. This element has been emphasised in the latest Canadian and US BIT models too.

As to the intention of the host-state, arbitral panels have generally granted it a wide discretion at the moment of identifying the public purpose involved in the measure adopted. Consequently, they have refrained from challenging the state's assessment. The sole-effect approach is dominant in ad hoc and ICSID panels. SPP, Goetz, Santa Elena, Lauder, Generation Ukraine, CMS, Eureko, ADC, Siemens and Compañia de Aguas del Aconquija have applied it. The most prominent exceptions to this trend are found in TECMED and Saluka. The police-powers solution in the former, later adopted in Azurix and partly in $L G \& E$, mixed the fair balance test of the European Court of Human Rights and some of the factors of the US Supreme Court 
case of Penn Central. The tribunal issued a confusing statement in TECMED. It declared that its review of the public purpose was aimed at establishing whether the BIT was breached, not at determining the legality of the expropriatory measure. Four years later, the award in Siemens returned to a more traditional position. This award expressly stated that the panel considered the purpose of the expropriation as one of the requirements of a lawful taking, and not as an element for the determination of whether the taking had occurred. Although it applied the sole-effect rule, the intrusive approach on the issue of public purpose, also adopted in $A D C$, cast doubts to the preeminence of this view in future arbitrations. Time will tell if the sole-effect approach applied in Compañia de Aguas del Aconquija will remain the general rule in the international law of expropriation. 


\section{MULTILATERAL RULES ON EXPROPRIATION}

From 1929 to 1998 , several attempts to regulate the property of aliens in a multilateral treaty failed at the League of Nations, the International Chamber of Commerce; the OECD, the UN, and the World Bank, among other organisations. The interest of the League of Nations and the International Chamber of Commerce in foreign investment was brief. The UN dealt initially with expropriation at the General Assembly, during the debates on the permanent sovereignty over natural resources and the NIEO. After the 1970s, its involvement with the treatment of aliens diminished significantly. The OECD played a leading role in the evolution of investment treaty-law during the 1960 s. It also had a centre-stage part in its involution during the 1990s. The World Bank established in the 1960s and the 1980s two of the most important organisations in the history of international investment law: ICSID and MIGA. Additionally, it drafted a set of general guidelines for the treatment of foreign investors, which filled the gap for multilateral rules on takings in international law.

In the meantime, a couple of institutions in the US issued non-binding instruments tackling the question of foreign investment. Both included an adaptation of their domestic takings doctrine to international law, in the form of a police-powers rule. NAFTA and the ECT incorporated investment provisions among their articles in the 1990s, which repeat to a large extent the takings clause found in BITs. Consequently, none of them openly opted for a sole-effect or a police-powers 
solution. Arbitral panels established under NAFTA have interpreted the undefined concepts of indirect expropriation and measures tantamount to it mentioned in this treaty. Early judicial decisions of these tribunals adopted a sole-effect approach. Such a solution was convenient for the US government when other host-states were in the dock. It became a threat when foreign investors started lodging expropriation claims against the US. The reaction was swift. Rejecting a position defended for more than a hundred years in the international fora, this country limited the protection of aliens to a national treatment rule and included its domestic regulatorytakings doctrine in recently concluded BITs and FTAs. The international minimum standard has thus been implicitly discarded by the US.

The various instruments that emerged out of these failed efforts of international organisations are studied in the present chapter. From the Havana Charter to the Multilateral Agreement on Investment. And beyond, for the expropriation clauses of EIAs currently in force are briefly analysed too. NAFTA case-law on indirect takings, particularly its answer to the threshold question, is addressed in detail. The US takings doctrine is also explained, and its progressive translation to international law is duly tracked down.

\subsection{Unsuccessful attempts and soft-law}

The creation of an international organisation focused on world trade was proposed in 1944 at a conference on economic affairs, held in Bretton Woods, New Hampshire, USA. Negotiations on its constitutive treaty took place within the UN Economic and Social Council (ECOSOC) in the following years. During them, the 
issue of expropriation of foreign property was discussed. The second session of the ECOSOC Preparatory Committee, held at Geneva in 1947, finished with a draft establishing that "just compensation" should be paid in case of taking. ${ }^{746}$ This provision was later deleted due to its lack of precision. The Charter for an International Trade Organization (Havana Charter) finally signed in Cuba's capital in 1948 included only generally-worded articles on the regulation of international investment. $^{747}$

Two unsuccessful initiatives to regulate foreign investment at a multilateral level were undertaken before the Havana Charter. In 1929, the League of Nations convened in Paris a diplomatic conference aimed at concluding an international convention on the treatment of aliens and foreign enterprises. A year later, the Hague Conference on the Codification of International Law included, among the issues to discuss, the responsibility of states for damage caused in their territory to the person or property of foreigners. Neither initiative achieved its objective, as Muchlinski points out, "owing to the refusal of Latin American, East European and ex-colonial states to accept the traditional international minimum standards of treatment insisted upon by the capital-exporting states", 748

\footnotetext{
${ }^{746}$ G Jaenicke, 'Havana Charter', in R Bernhardt (ed.), EPIL (1995), Vol. II, 680. See, also, Lowenfeld, supra note 102, at 405.

In this conference, a draft of a multilateral treaty containing general principles of trade was completed under the name of General Agreement on Tariffs and Trade (GATT). As the negotiations of the Havana Charter continued, GATT parties adopted a Protocol of Provisional Application to apply this treaty from 1948 without waiting for the Havana Charter to be enforceable.

M Matsushita, T Schoenbaum and P Mavroidis, The World Trade Organization. Law, Practice, and Policy (2004), 2.

${ }^{747}$ See Jaenicke, supra note 746, at 680; and Matsushita, Schoenbaum and Mavroidis, supra note 746, at $1-2$.

${ }^{748}$ P Muchlinski, Multinational Enterprises and the Law (1995), 573-4.

See, also, S Picciotto, 'Linkages in International Investment Regulation: The Antinomies of the Draft Multilateral Agreement on Investment', (1998) 19 UPenn. JIEL 731, at 742-3.
} 
Following the demise of the Havana Charter, private-sector bodies in Europe made several efforts to conclude a multilateral treaty on foreign investment. International organisations took part in this attempt as well. But while the failed OECD Draft Convention of 1967 indirectly developed international investment law through European BIT models, the abandonment of its Multilateral Agreement on Investment (MAI) was an important set-back in the evolution of this branch of law thirty years later. The World Bank group has been more successful. Its progressive engagement with international investment law led not only to the creation of ICSID in 1965 and MIGA in 1985, but also to the publication of its Guidelines on the Treatment of Foreign Direct Investment in 1995.

\subsubsection{Early efforts to address expropriation}

Although the Havana Charter was signed by fifty-four countries, a good number in those days, it eventually failed to enter into force. ${ }^{749}$ The investment articles of this treaty were reduced to two generally worded provisions, after the payment of just compensation for takings was excluded from its final version. ${ }^{750}$ Article 11 established a broad protection of foreign investment in the form of a negative obligation on the members of the International Trade Organization (ITO) to avoid adopting unreasonable or unjustifiable measures within its territory, injurious to the rights or interests of nationals of other members. The great value of foreign investment in the promotion of economic development and social progress was recognised in Article 12. It required ITO members to stimulate the flow of foreign

\footnotetext{
749 Jaenicke, supra note 746 , at 679 .

${ }^{750}$ Available at <http://www.worldtradelaw.net/misc/havana.pdf $>$ (last visited $31 \mathrm{March}, 2008$ ).
} 
capital to their territories, while acknowledging the right of the host-state to regulate its entry. Endorsing FCNs, the same provision encouraged the conclusion of bilateral and multilateral treaties for the promotion and protection of foreign investment among its members.

Because US support for the Havana Charter was decisive, other contracting states decided to wait for its ratification in this country. President Truman submitted this treaty to the US Congress in 1948. Two years later, his administration announced that it would no longer seek the approval for the ITO. ${ }^{751}$ The Havana Charter was abandoned in 1950, according to Lowenfeld, mostly for reasons not related with its investment provisions. ${ }^{752}$ In his view, the US administration considered:

that support for the Havana Charter might impair support for higher-priority issues of foreign affairs such as the Marshall Plan for the reconstruction of Europe [...] and (from the summer of 1950 on) pursuit of the war in Korea. ${ }^{753}$

Not all authors agree with this position. Tschofen considers that among the main reasons for the failure of the Havana Charter was its "unsatisfactory provisions on foreign investment" ${ }^{754}$ Muchlinski recalls that these provisions caused widespread opposition to the treaty among the business community in the US. ${ }^{755}$ Riesenberg is of the same opinion. US business interests had particularly strong objections to Article 12, whose investment protection was considered to be "too vague and too weak". ${ }^{756}$ Loppacher and Keer add that the same countries that had pushed for investment to be included in the Havana Charter, including the US, began to fear that the agreement, as negotiated, did not provide adequate guarantees against

\footnotetext{
${ }_{752}^{751}$ Matsushita, Schoenbaum and Mavroidis, supra note 746, at 2.

${ }^{752}$ Lowenfeld, supra note 102 , at 405.

${ }^{753}$ Ibid., 25-6.

${ }^{754}$ Tschofen, supra note 236 , at 387.

${ }^{755}$ Muchlinski, supra note 748, at 574; and Muchlinski, supra note 639, at 1037.

${ }^{756}$ Riesenfeld, supra note 186 , at 436.
} 
expropriation. ${ }^{757}$ Whatever the cause was, the abandonment of the Havana Charter in the US led the other signatories to desist from securing its ratification in their respective states.

The ICC, a non-governmental organisation based in Paris, drafted the International Code of Fair Treatment for Foreign Investments in 1949. Among other protections, this instrument provided that the expropriation of the property of aliens should only be adopted with the appropriate legal procedure and fair compensation, to be determined prior to the taking according to international law. ${ }^{758}$ Designed as a model to be followed in the negotiation of bilateral and multilateral treaties, the ICC Code was presented to the UN for consideration by the governments and the ECOSOC, but it was never adopted. ${ }^{759}$ Almost ten years later, the Society to Advance the Protection of Foreign Investments -a private organisation based in Cologne, Germany- drew up the International Convention for the Mutual Protection of Private Property Rights in Foreign Countries. This draft, prepared under the guidance of Hermann Abs, chairperson of the Deutsche Bank, was combined in 1957 with another one prepared under the leadership of the UK's attorney-general, Lord Shawcross. Issued in 1959 as the Draft Convention on Investments Abroad, and commonly referred to as the Abs/Shawcross Draft, this instrument did not expressly establish the right to expropriate, but acknowledged it by implication. ${ }^{760}$ According to its authors, Article III of the draft was based on the idea that every state enjoys a sovereign right to nationalise or expropriate all property situated in its territory. In the case of alien property, they added, this right may only be exercised under certain

\footnotetext{
${ }^{757}$ Loppacher and Kerr, supra note 753 , at 40.

${ }^{758}$ Tschofen, supra note 236, at 388.

${ }^{759}$ Ibid.

${ }^{760}$ See ibid., $389 \& 407$.
} 
conditions. $^{761}$ Article III followed some of the requirements of a lawful expropriation:

No Party shall take any measures against nationals of another Party to deprive them directly or indirectly of their property except under due process of law and provided that such measures are not discriminatory or contrary to undertakings given by that Party and are accompanied by the payment of just and effective compensation. Adequate provision shall have been made at or prior to the time of deprivation for the prompt determination and payment of such compensation, which shall represent the genuine value of the property affected, be made in transferable form, and be paid without undue delay. ${ }^{762}$

The comment on the Abs/Shawcross Draft explained that the purpose of this provision was to restate the international minimum standard. ${ }^{763}$ The just compensation mentioned in the draft closely resembled the Hull formula. It was, for the authors, the same standard applied in the Norwegian Shipowners' claim and the Chorzow Factory case, among other judicial decisions. The comment further recognised that the Abs/Shawcross Draft closely followed US FCNs. In fact, it was more protective than them and the multilateral efforts that foundered in the past. ${ }^{764}$ For instance, Article III's protection against direct and indirect takings had to be read in connection to Article IX (b) of the same instrument. Adopting a broad concept of investment, the circular definition of this provision stated: "'property' includes all property, rights, and interests, whether held directly or indirectly". ${ }^{765}$ Article IX (b) went on to explain that "[a] member of a company shall be deemed to have an interest in the property of the company" ${ }^{766}$ From this perspective, Schwarzenberger

\footnotetext{
${ }^{761}$ See 'Comment on the Draft Convention by its Authors', (1960) JPL 119, at 121.

${ }^{762}$ Art. III of the Abs/Shawcross Draft, available at

<http://www.unctad.org/sections/dite/iia/docs/Compendium//en/137\%20volume\%205.pdf> (last visited 31 March, 2008).

${ }^{763}$ See 'Comment on the Draft Convention by its Authors', supra note 761, at 121.

${ }^{764} \mathrm{~S}$ Metzger, 'Multilateral Conventions for the Protection of Private Foreign Investment', (1960) 9 $J P L 133$, at 133-4.

${ }^{765}$ Art. IX (b) of the Abs/Shawcross Draft.

See note 762, supra.

${ }^{766}$ Ibid.
} 
noted, the omission of the public interest requirement for lawful takings was all the more surprising. ${ }^{767}$ The Abs/Shawcross Draft was submitted by the Federal Republic of Germany to the OECD for "consideration and appropriate action" ${ }^{768}$ Never concluded as a treaty, it was the basis of yet another unsuccessful attempt: the Draft Convention on the Protection of Foreign Property of the OECD.

\subsubsection{Guidelines for a lack of agreement}

The OECD Draft Convention was prepared by a committee of this international organisation. Though its publication was approved by a resolution of the Council of the OECD in 1967, the draft failed to gain sufficient international support and was never opened to signature. It was only recommended by this international organisation to its members as a model for investment protection treaties. Muchlinski points out that the opposition of less developed southern-European members of the OECD prevented the convention from being adopted. ${ }^{769}$ Dolzer and Stevens add another reason for the failure of the Draft Convention: the fact that it was originally intended as a multilateral instrument applicable to all states, and not only to OECD members. ${ }^{770}$ Negotiating a treaty within an international organisation formed by developed states, aimed mainly at the protection of foreign investments in developing countries, would also prove to be fatal thirty years later for the MAI.

\footnotetext{
${ }^{767}$ G Schwarzenberger, 'The Abs-Shawcross Draft Convention on Investments Abroad: A Critical Commentary', (1960) 9 JPL 147, at 156.

${ }^{768}$ Tschofen, supra note 236, at 389.

${ }^{769}$ Muchlinski, supra note 748, at 574; and Muchlinski, supra note 639, at 1036.

${ }^{770}$ Dolzer and Stevens, supra note 16, at 2.
} 
Article 3 of the OECD Draft Convention referred to expropriation, declaring that no party shall adopt any measure depriving directly or indirectly a national of another party of his property, unless the host-state complied with the conditions of a lawful taking: public interest, non-discrimination, payment of compensation, and due process of law. In conformity with its official commentary, Article 3 was meant to cover in particular "creeping nationalisations", defined as measures otherwise lawful, applied in such a way as to "deprive ultimately the alien of the enjoyment or value of his property", without any specific identifiable act of outright expropriation. ${ }^{771}$ The commentary mentioned, as examples of this type of taking, excessive or arbitrary taxation; prohibition of dividend distribution coupled with compulsory loans; imposition of administrators; prohibition of dismissal of staff; and refusal of access to raw materials or of essential export or import licenses. ${ }^{772}$ The same notes and comments stressed that "[t]he taking of property, within the meaning of the Article, must result in a loss of title or substance". ${ }^{773}$

In this context, the police-powers solution adopted by the OECD Draft Convention is unexpected. Although nothing in the actual wording of Article 3 denoted such an approach, its commentary made this solution explicit, by stating that the provision brought "within its compass any measures taken with the intent of wrongfully depriving the national concerned of the substance of his rights and resulting in such loss". ${ }^{774}$ This is a confusing statement. The notes and comments on Article 3 had acknowledged before the right of the host-state to expropriate, and expressly reconciled this right with its correspondent obligation to respect and

\footnotetext{
771 'O.E.C.D. Draft Convention on the Protection of Foreign Property', (1968) 7 ILM 117, note 4 (b) at $125-6$.

${ }^{772}$ OECD Draft Convention, note 4 (b) at 126.

${ }^{773} \mathrm{Ibid}$.

${ }^{774}$ OECD Draft Convention, note 4 (a) at 125.
} 
protect foreign property through the fulfilment of the four conditions of a lawful taking. ${ }^{775}$ Why add "with the intent of wrongfully depriving" then? This confusion still haunts the debate on indirect takings today.

As to other aspects of a taking, the official commentary followed recognised rules of international law. Regarding indirect expropriations, it made clear that whether the host-state's interference with property amounted to a deprivation depended "on its extent and duration". ${ }^{776}$ In a position later adopted by the Iran-US CT, the notes and comments explained that though a measure may purport to be temporary, there comes a stage at which there is no immediate prospect that the owner will be able to resume the enjoyment of his property. ${ }^{777}$ On the requirement of public purpose, the commentary to Article 3 said that it implies that the expropriatory measures must be adopted in the interest of the state or any of its political subdivisions, not solely for private gain. ${ }^{778}$ Just compensation in Article 3 was described in the terms of the Hull formula. Its notes and comments confirmed this approach. ${ }^{779}$ Finally, the official commentary equated due process with the AngloSaxon concept of rule of law or the Continental notion of rechtsstaat, containing both substantive and procedural elements present not only in the domestic law of the state concerned, but also in the principles of international law. ${ }^{780}$ The judicial review of the expropriatory measure by an independent administrative or judicial tribunal

\footnotetext{
${ }^{775}$ Ibid., notes 1 (a) \& 3 at 125.

${ }^{776}$ Ibid., note 4 (b) at 125 .

${ }^{777}$ Ibid.

See Chapter 4 supra.

${ }^{778}$ OECD Draft Convention, note 5 at 126.

${ }^{779}$ Ibid., notes 8 \& 9 at 126.

${ }^{780} \mathrm{Ibid}$., note 6 at 126 .
} 
was highlighted as an important safeguard included in this requirement of due process. ${ }^{781}$

More than two decades after the adoption of the OECD Draft Convention, the UN abandoned its Draft Code of Conduct on Transnational Corporations (TNCs). ${ }^{782}$ The legitimacy of the claims of capital-importing states for greater control over TNCs was gradually accepted by international organisations, which began to study in the 1970 s how to balance the interests of foreign investors and of the host-states. ${ }^{783}$ It was against this background that the UN Code of Conduct was negotiated within the Commission on TNCs, established in 1974 by ECOSOC for the purpose of drafting this instrument. The last version available of the UN Draft Code is the text submitted in 1990 to ECOSOC by the chairman of the Commission on TNCs, reflecting the status of the negotiations as at $1986 .{ }^{784}$ In the end, this instrument was never adopted, mainly because of strong disagreements between capital-importing and capitalexporting countries over fundamental issues related to its content, legal status and relationship with general international law. ${ }^{785}$ The UN Draft Code, nonetheless, still informs issues of corporate responsibility debated in the negotiation of investment treaties. ${ }^{786}$ It recognised the sovereign right to expropriate foreign property, directly or indirectly, which must be exercised in accordance with international law. In relation to the requirements of a lawful taking, the UN Draft Code mentioned not only public purpose, the payment of compensation and due process of law, but also the respect of specific undertakings not to expropriate, adopted by contract or other

\footnotetext{
${ }^{781}$ Ibid., note 6 (c) at 126.

${ }^{782}$ See Muchlinski, supra note 748 , at $592-7$.

${ }^{783}$ Muchlisnki, supra note 639 , at 1037.

${ }^{784}$ Available at

$<$ http://www.unctad.org/sections/dite/iia/docs/Compendium//en/13\%20volume\%201.pdf > (last visited 31 March, 2008).

${ }^{785}$ Muchlisnki, supra note 748 , at 594.

${ }^{786}$ Muchlinski, supra note 639 , at 1037.
} 
agreement, already recognised in the Abs/Shawcross Draft. Compensation was described as prompt, adequate and effective, and as appropriate in an alternative version. According to the UN Draft Code, expropriation claims should be settled under the domestic law of the host-state and by its tribunals, respecting the international obligations freely undertaken by the authorities of this country. ${ }^{787}$

Another instrument that informs the negotiation and application of investor protections in BITs and EIAs is the Guidelines on the Treatment of Foreign Direct Investment adopted by the World Bank group in $1992 .{ }^{788}$ Its Development Committee, a joint body with the International Monetary Fund, decided in 1991 to set-up a working group consisting of lawyers from each of the institutions of the World Bank for the purpose of drafting a legal framework to FDI. ${ }^{789}$ A report was prepared by this working group and submitted a year later to the Development Committee. It explained that the World Bank Group could not issue binding rules to states, and that although a multilateral treaty could be drawn and opened for signature, such a solution was not recommended, given the reluctance of states to commit themselves to this type of instruments in the area of foreign investment. The working group recommended the World Bank to issue non-binging guidelines instead, based on the general trends identified in the review of existing legal instruments, doctrine, available practice, and on the policies advocated by it in recent

\footnotetext{
${ }^{787}$ See UN Code of Conduct, para. 54.

${ }^{788}$ See note 616, supra.

See, in general, I Shihata, Legal Treatment of Foreign Investment: The World Bank Guidelines (1993).

${ }^{789}$ I.e., the International Bank for Reconstruction and Development (IBRD), the International Finance Corporation (IFC), the International Development Association (IDA), ICSID, and MIGA.
} 
years. The resulting text was approved by the Development Committee for circulation among the member states of the World Bank group. ${ }^{790}$

The preamble of the Guidelines expressly state their purpose and nature. They are aimed at achieving a desirable overall framework of essential principles that would promote FDI in the common interest of all of the World Bank's members. As it declares, the Guidelines are "not ultimate standards but an important step in the evolution of generally acceptable international standards which complement [BITs or EIAs]". ${ }^{791}$ In fact, investment treaties take precedence to them in case of conflict between the two. ${ }^{792}$ There is no doubt that the Guidelines fit the description of softlaw found in the writings of some scholars. ${ }^{793}$ That is to say, instruments which are normative in substance, but not in a legally binding form. Although the choice of words in "soft-law" -attributed to McNair- is certainly poor, for it reveals a contradiction in terms, the concept has generally been accepted in international doctrine. Not without dissenters, though, most notably Klabbers and Weil. ${ }^{794}$ The Guidelines encourage the admission of foreign investment, and at the same time recognise the right of the host-state to make regulations governing its admittance. ${ }^{795}$ They also acknowledge the right of the state to expropriate "or otherwise take" -in whole or in part- foreign investment, or to adopt "measures which have similar

\footnotetext{
${ }^{790}$ See Muchlinski, supra note 748 , at 598.

${ }^{791}$ Preamble, para. 6.

See note 616, supra.

${ }^{792}$ Guideline I, Section 1.

${ }^{793}$ See C Chinkin, 'The Challenge of Soft Law: Development and Change in International Law', (1989) 38/IV ICLQ 850; H Hillgenberg, 'A Fresh Look at Soft Law', (1999) 10/III EJIL 499; P Birnie and A Boyle, International Law \& the Environment (2002), 24-7; C Chinkin, 'Normative Development in the International Legal System', in D Sheldon (ed.), Commitment and Compliance. The Role of Non-Binding Norms in the International Legal System (2003); A Boyle, 'Soft Law in International Law-Making', in M Evans (ed.), International Law (2006); and Boyle and Chinkin, supra note 54 , at $210-29$.

${ }^{794}$ See P Weil, 'Towards Relative Normativity in International Law?', (1983) 77 AJIL 413; and J Klabbers, 'The Redundancy of Soft Law', (1996) 65 Nor. JIL 167.

${ }^{795}$ Guideline II.

See note 616, supra.
} 
effects", following these conditions: "in accordance with applicable legal procedures, in pursuance in good faith of a public purpose, without discrimination on the basis of nationality and against the payment of appropriate compensation". ${ }^{796}$ The latter is described in the terms of the Hull formula. ${ }^{797}$ In case of nationalisation, the Guidelines recommend the determination of its compensation through negotiations between the host-state and the state of the expropriated foreigner, and failing this, through international arbitration. ${ }^{798}$ Regarding the settlement of investment disputes, the Guidelines declare that they should be normally settled through negotiations. Failing this, through domestic courts or other agreed mechanisms, including binding independent arbitration, agreed upon in writing, in which case they encourage states to accept ICSID's jurisdiction. ${ }^{799}$

\subsection{The US doctrine in international law}

The Fifth Amendment of the US Constitution, passed in 1791, declares that no person shall be deprived of property without due process of law, nor shall it be taken for public use, without just compensation. This provision is commonly known as the takings clause. ${ }^{800}$ The inherent power of federal and state authorities to expropriate privately owned property under these conditions is called eminent domain. ${ }^{801}$ The takings clause was applied by the US Supreme Court exclusively to

\footnotetext{
${ }^{796}$ Guideline IV, Section 1.

${ }^{797}$ Ibid., Section 2-9.

${ }^{798}$ Ibid., Section 10.

${ }^{799}$ Guideline V.

${ }^{800}$ Garner, supra note 11 , at 1467.

${ }^{801}$ Ibid., 541.

It is called compulsory acquisition of property in the UK.

Mann, supra note 9, at 188.
} 
the direct appropriation of property until the $20^{\text {th }}$ century. ${ }^{802}$ After Lochner, this tribunal used a combination of the Fifth and Fourteenth Amendments -the latter insisting on the prohibition of deprivations without due process of law-, to construe virtually any change in the law or its application that altered property as a taking. ${ }^{803}$ The concept of regulatory taking emerged in Pennsylvania Coal. In this case, the US Supreme Court recognised that regulation could amount to an expropriation depending on the extent of the diminution of the property's value. ${ }^{804}$ According to Lucas, however, this tribunal will normally get to this conclusion when the measure eliminates all or substantially all this value. ${ }^{805}$ Concrete Pipe stated that the mere diminution, however serious, is insufficient to establish a taking. ${ }^{806}$

The two per se rules in the US takings doctrine are that the permanent physical occupation of property, or a one hundred percent destruction of its value as a result of a regulatory measure, will require compensation. ${ }^{807}$ Outside these situations, an $\mathrm{ad}$ $h o c$ inquiry is needed for determining whether a regulation constitutes a taking. The three factors that aid this inquiry were first articulated in Penn Central. This is, the economic impact of the regulation on the claimant, the extent to which it has

\footnotetext{
${ }^{802}$ E Graham, Regulatory Takings, Supernational Treatment, and the Multilateral Agreement on Investment: Issues Raised by Nongovernmental Organizations, (1998) 31 Corn. ILJ 599, at 604; and R Stumberg, 'Sovereignty by Subtraction: The Multilateral Agreement on Investment', (1998) 31 Corn. ILJ 491, at 557.

${ }^{803}$ See Lochner v. People of the State of New York, (1905) 198 US 45.

See, also, Graham, supra note 802, at 604-5.

${ }^{804}$ See Pennsylvania Coal Co. v. Mahon, (1922) 260 US 393.

See, also, Graham, supra note 802, at 605-6; Stumberg, supra note 802, at 557; and E Shenkman, 'Could Principles of Fifth Amendment Takings Jurisprudence be Helpful in Analyzing Regulatory Expropriation Claims under International Law?', (2003) 11 NYU ELJ 174, at 174.

${ }^{805}$ See Lucas v. South Carolina Coastal Council, (1992) 505 US 1003.

See, also, Stumberg, supra note 802, at 557-8.

${ }^{806}$ See Concrete Pipe and Products of California, Inc. v. Construction Laborers Pension Trust for Southern California, (1993) 508 US 602.

See, also, Stumberg, supra note 802, at 558.

${ }^{807}$ Been and Beauvais, supra note 583, at 61-2.
} 
interfered with distinct investment-backed expectations, and the character of the governmental action. ${ }^{808}$ Nonetheless, as Been and Beauvais explain:

it is extremely difficult to prove a regulatory taking under U.S. takings jurisprudence: U.S. Courts almost never find that a regulation has destroyed one hundred percent of the value of the property, and they seldom find that a regulation effects a taking under the Penn Central analysis. ${ }^{809}$

The investment chapters of the FTAs concluded in recent years by the US, as well as its latest BIT model, include an international protection against expropriation strongly rooted in this domestic regime. Timidly introduced in international instruments at the second half of the $20^{\text {th }}$ century, it was only after the regulatory powers of developed states were challenged recently in investor-to-state disputes that the US openly adopted the Penn Central factors in its treaties.

\subsubsection{Different formulations for different approaches}

The UN Secretariat requested Harvard University professors Louis Sohn and Richard Baxter in 1961 to revise and update a draft convention on the international responsibility of states for injuries to aliens prepared by this academic institution in 1929. Their work was done with the help of an advisory committee formed by professors of other law schools and practising lawyers in the US, and was presented to the ILC on the same year. ${ }^{810}$ According to its authors, the Draft Convention on the International Responsibility of States for Injuries to Aliens -generally known as the Harvard Draft- was based on the principle of an international minimum standard governing the treatment of aliens. Its purpose was not only "to codify with some

\footnotetext{
${ }^{808}$ See Penn Central Transportation Co. v. New York City, (1978) 438 US 104.

${ }^{809}$ Been and Beauvais, supra note 583 , at $61-2$.

${ }^{810}$ L Sohn and R Baxter, 'Responsibility of States for Injuries to the Economic Interests of Aliens', (1961) 55 AJIL 545, at 545-6.
} 
particularity the standards established by international law for the protection of aliens and thereby to obviate, as far as possible, the necessity of looking to customary international law", but also to develop these norms when necessary by the incorporation of "international standards of the principles of law or of justice recognized by the principal legal systems of the world". 811

The Harvard Draft was by far the most detailed instrument regulating the protection against expropriation in its time. The elements of a lawful taking included in Article 10 were public purpose, and payment of compensation in conformity with the Hull formula. The first requirement had to be "clearly recognized as such by a law of general application in effect at the time of the taking" 812 The explanatory note on Article 10 points out that this qualification was intended to preclude ad hoc determinations of public purpose by government officials "acting without any express authority in law". 813 The same note observed that the content of this condition had never been defined with any degree of precision in comparative law, and that international tribunals had rarely embarked upon a survey of what in fact constitutes public purpose. ${ }^{814}$ The second requirement was described in Article 10 and its explanatory note following Hull's formulation. ${ }^{815}$ If no compensation was paid, damages would provide reparation for the unlawful taking. In case of a taking adopted not for a public purpose or in violation of a treaty, restitution was the ordinary remedy. The owner would have no obligation to accept the compensation tendered. But if he did accept it, his claim to restitution of the property should be

\footnotetext{
811 Ibid., 547.

${ }^{812}$ Harvard Draft, Art. 10, para. 1 (a) \& para. 2.

${ }^{813}$ Sohn and Baxter, supra note 810 , at 556.

${ }^{814}$ Ibid., 555-6

${ }^{815}$ Harvard Draft, Art. 10 paras. $2 \& 6$.

See Sohn and Baxter, supra note 810, at 557-8 \& 562-3.
} 
considered waived. ${ }^{816}$ The requirement of compensation was applicable also for nationalisations. In this case, however, Article 10 allowed the host-state to pay it over a "reasonable period of years", under certain conditions. ${ }^{817}$ The Harvard Draft defined the concept of property applicable to this provision in broad terms, comprising tangibles and intangibles ${ }^{818}$. Article 10 explicitly included in its coverage not only outright takings, but also:

any such unreasonable interference with the use, enjoyment, or disposal of property as to justify an inference that the owner thereof will not be able to use, enjoy, or dispose of the property within a reasonable period of time after the inception of such interference. $^{819}$

Several examples of indirect takings are mentioned in the explanatory note blocking the entrance of a factory to make impossible its operation by the alien; denying entry visas for foreign technical personnel; the appointment of managers and inspectors interfering with the free use by the alien of its investment, among others. ${ }^{820}$ The case-law of the Iran-US CT and early ad hoc arbitrations had to deal with some of them. ${ }^{821}$ Although still possible, they seem rather dated today. Current investment disputes are aimed mostly at challenging highly-sophisticated contractual and regulatory schemes. The note also explained that whether an interference with property constituted an expropriation depends upon the duration of the interference. This determination might prove particularly difficult, considering that Article 10 expressly recognised the possibility of temporary takings. ${ }^{822}$ The unreasonableness of the interference was to be determined in conformity with general principles of law. ${ }^{823}$

\footnotetext{
${ }^{816}$ Ibid., 556-7.

${ }^{817}$ See Harvard Draft, Art. 10 para. 4.

See, also, Sohn and Baxter, supra note 810, at 557 \& 559-61.

${ }^{818}$ Harvard Draft, Art. 10 para. 7.

${ }^{819}$ Harvard Draft, Art. 10, para. 3 (a).

${ }^{820}$ Sohn and Baxter, supra note 810 , at 559.

${ }^{821}$ See Chapter 4 supra.

${ }^{822}$ Harvard Draft, Art. 10, para. 3 (b).
} 
The Harvard Draft followed, to some extent, the US regulatory-takings doctrine. Article 10 described certain non-compensable state regulations in such wide terms, that in practice it established a police-powers rule. According to this, an uncompensated deprivation of property derived from the execution of tax laws; the general change in the value of currency; the action of competent authorities in the maintenance of public order, health, or morality; the valid exercise of belligerent rights; or the normal operation of the laws of the state, was not considered wrongful if it complied with the following requirements: it did not amount to a clear and discriminatory violation of the host-state; it was not in breach of due process of law; it was not an "unreasonable departure from the principles of justice recognized by the principal legal systems of the world"; and it was not a result of the abusive exercise of the regulatory powers of the host-state with the intention of depriving an alien of his or her property. ${ }^{824}$ The explanatory note confirmed this approach when it mentioned "the requisite intent" necessary in the adoption of a measure that amounts to an expropriation. ${ }^{825}$

The police-powers exception included almost twenty years later in the 1985 MIGA Convention ${ }^{826}$ was not worded in the terms of the Harvard Draft, but from a sole-effect perspective. ${ }^{827}$ MIGA is an international organisation, member of the World Bank group, aimed at encouraging FDI into developing states mainly by providing insurance to investors against political or non-commercial risks in these

\footnotetext{
See Sohn and Baxter, supra note 810, at 554.

${ }^{823}$ Ibid., 559.

${ }^{824}$ Harvard Draft, Art. 10 para. 5.

See Sohn and Baxter, supra note 810, at 561-2.

${ }^{825}$ Ibid., 559.

${ }^{826}$ In force since 1988.

${ }^{827}$ See Newcombe, supra note 50 , note 88 at 22.
} 
countries. ${ }^{828}$ Article 11 of its constitutive treaty describes expropriation and similar measures as one of the covered risks, in these terms:

any legislative action or administrative action or omission attributable to the host government which has the effect of depriving the holder of a guarantee of his ownership or control of, or a substantial benefit from, his investment, with the exception of non-discriminatory measures of general application which governments normally take for the purpose of regulating economic activity in their territories. ${ }^{829}$

Regarding the concept of property protected, the MIGA Convention did not innovate either in relation with former international investment treaties: eligible investments for coverage under this treaty can be both portfolio investment and FDI. ${ }^{830}$

The American Law Institute prepared the Third Restatement of the Foreign Relations Law of the United States in $1987 .{ }^{831}$ It adopted a police-powers rule closer to the Harvard Draft's than to an exception from a sole-effect standpoint. Section 712 , on state responsibility for economic injury to nationals of other states, mentions three requirements for a lawful taking: public purpose, non-discrimination -i.e. no unreasonable distinction- and payment of just compensation, described on the terms of the Hull formula. ${ }^{832}$ The commentary on this section observes that although public purpose is reiterated in most formulations of the protection against expropriation, this condition has not figured prominently in international case-law "perhaps because the concept $[\ldots]$ is broad and not subject to effective re-examination by other states", 833

\footnotetext{
${ }^{828}$ It also advises developing governments on how to attract foreign investment, shares information by means of online services, and mediates investor-to-state disputes.

See, in general, <http://www.miga.org> (last visited 31 March, 2008).

${ }^{829}$ MIGA Convention, Art. 11 (a) (ii), available at

$<$ http://www.unctad.org/sections/dite/iia/docs/Compendium//en/16\%20volume\%201.pdf $>$ (last visited 31 March, 2008).

${ }^{830}$ Art. 12 of the MIGA Convention.

${ }^{831}$ The American Law Institute is an NGO established in 1923 for the improvement of the law and the administration of justice in the US.

${ }^{832}$ American Law Institute, supra note 51 , at $196-7$ \& 200.

${ }^{833}$ Ibid., 200.
} 
That direct and indirect takings are included in this provision is confirmed in another comment, which describes the latter as an unreasonable interference, preventing or delaying the effective enjoyment of an alien's property. ${ }^{834}$ Nonetheless, the same explanatory note adds:

A state is not responsible for loss of property or other economic disadvantage resulting from bona fide general taxation, regulation, forfeiture for crime, or other action of the kind that is commonly accepted as within the police powers of states, if it is not discriminatory. ${ }^{835}$

Not surprisingly, the reporters' notes to Section 712 of the Third Restatement stated that generally the line between compensable and non-compensable regulatory actions in international law is similar to that drawn in the US case-law on the Fifth Amendment. ${ }^{836}$

The issue of expropriation was addressed in a multilateral treaty two years after the conclusion of the MIGA Convention. The 1987 Agreement for the Promotion and Protection of Investments, of the Association of Southeast Asian Nations (ASEAN) as amended by its 1996 Protocol-, includes in Article VI the four requirements of a lawful taking found in most BITs. ${ }^{837}$ Besides the conditions of public purpose, nondiscrimination, compensation, and due process of law, it adheres to the Hull formula, and refers to "expropriation, nationalisation or any measure equivalent thereto". Nothing in the wording of this provision reflects a sole-effect or a police-powers approach. Article I has a broad asset-based definition of investment, complemented by a list of examples that comprises tangibles and intangibles. FDI and portfolio

\footnotetext{
${ }^{834}$ Ibid.

${ }^{835}$ Ibid., 201.

${ }^{836}$ Ibid., 211.

837 This treaty was concluded in 1987 by Brunei, Indonesia, Malaysia, Philippines, Singapore, and Thailand, and entered into force in 1990. Lao and Myanmar acceded to it in 1996. Available at <http://www.aseansec.org/12812.htm> (last visited 31 March, 2008).

See, also, Tschofen, supra note 236, at 392; Sornarajah, supra note 3, at 290-1; and $<\mathrm{http}$ //www.aseansec.org/12807.htm> (last visited $31 \mathrm{March}, 2008$ ).
} 
investment are covered by the ASEAN agreement, but only if they have been approved by the host-state, according to Article II. The effectiveness of the treaty protections is guaranteed by Article $\mathrm{X}$, which gives the foreign investor the possibility of bringing a claim -after consultation- before ICSID, UNCITRAL or any regional centre of arbitration in ASEAN, in order to settle investment disputes with the host-state. These controversies can also be brought before the ASEAN Dispute Settlement Mechanism, as provided in the 1996 Protocol.

The ECT also referred to expropriation in $1994 .{ }^{838}$ Concluded as a reaction to the collapse of the Soviet Union, the ECT was an international effort to integrate the energy sector of former Soviet states with that of Western Europe and provide the legal foundations for energetic security, based on an open and competitive market. Today, it has more than 50 member-states in Asia and Europe. The investment regime in ECT was largely based in UK BITs and NAFTA's Chapter $11 .^{839}$ As a consequence, the definition of investment is wide, followed by a list of examples that comprise tangibles and intangibles, though limited to a specific sector of the economy: energy. ${ }^{840}$ Article 13 repeats the four conditions of a lawful taking, including the Hull formula, and mentions measures having an effect equivalent to an expropriation or nationalisation. As with the ASEAN Agreement, neither a soleeffect nor a police-powers solution is reflected in its wording. The settlement of investor-to-state disputes is regulated in Article 26. It gives the claimant the choice of initiating arbitrations proceedings under the Washington Convention, the

\footnotetext{
${ }^{838}$ See note 220 , supra.

The ECT is in force since 1998.

${ }^{839}$ T Waelde, 'Energy Charter Treaty-based Investment Arbitration. Controversial Issues', (2004) 5/III JWIT 373, at 376.

${ }^{840}$ UNCTAD, supra note 19 , at 125.
} 
Additional Facility Rules of ICSID ${ }^{841}$, the UNCITRAL rules, or before the Arbitration Institute of the Stockholm Chamber of Commerce, after consultation.

\subsubsection{Replacing the minimum for a maximum}

The investment provisions of the 1992 NAFTA are found in Chapter 11, called by some the investors' bill of rights. ${ }^{842}$ NAFTA was an expansion to the earlier 1988 Canada-US FTA, based in the US BIT-model then available. The Canada-US FTA did not include the direct referral of investment disputes to international arbitration. ${ }^{843}$ NAFTA provides for such possibility. Its Article 1120 gives the investor the chance of opting among the Washington Convention, the Additional Facility Rules of ICSID, or the UNCITRAL Arbitration Rules, following a period of consultation between the disputing parties. The takings provision is Article 1110 . The requirements of a lawful expropriation included in it are, again, public purpose, non-discrimination, payment of compensation, and due process of law. Compensation is described in detail according to the Hull formula. Article 1110 also adds another condition: the expropriatory measure must be adopted in accordance with FET, and full protection and security. As to the investment protected by the international standard, NAFTA contains an innovative definition. While BITs

\footnotetext{
${ }^{841}$ These rules authorise the ICSID Secretariat to administer conciliation and arbitration proceedings between host-states and foreign investors for disputes which fall outside the scope of the Washington Convention.

${ }^{842}$ Been and Beauvais, supra note 583 , at 40 .

NAFTA entered into force in 1994.

See note 216 , supra.

${ }^{843}$ Instead, these disputes had to be brought before to an intergovernmental commission, which had the discretionary power to refer them later to arbitration.

See Arts. 1801-06 of the Canada-US FTA, (1988) 27 ILM 281.

See, also, Been and Beauvais, supra note 583, at 51-2.
} 
normally provide an illustrative list of assets, Article 1139 establishes a closed or exhaustive one, with specific exclusions. In other words, what is not in this definition is not covered by the treaty. The list in NAFTA includes tangible and intangible property. $^{844}$

Direct and indirect nationalisations and expropriations are expressly mentioned in Article 1110, as well as measures tantamount to them. Measure is defined in Article 201, paragraph 1, as any law, regulation, procedure, requirement or practice. Like other investment treaties, NAFTA gives no concept of expropriation and nationalisation, whether direct or indirect. This was a deliberate omission. The strategy of its drafters was to leave the solution to the problem of how to distinguish non-compensable regulation and indirect takings to the arbitration panels. As one of the principal US negotiators in NAFTA recalls:

If the United States Supreme Court and arbitral tribunals could not do it in over 200 years, it was unlikely that the negotiators were going to do it in a matter of weeks with one line in a treaty. ${ }^{845}$

No clear solution is found in the treaty on the problem of intent. In conformity with Article 1114, nothing in Chapter 11 shall be construed to prevent a contracting party from adopting, maintaining or enforcing any measure otherwise consistent with it, that this party considers appropriate to ensure that the investment activity in its territory is undertaken in a manner sensitive to environmental concerns. ${ }^{846}$ This provision might well be interpreted as a police-powers rule, or a police-powers exception from a sole-effect perspective. In both cases, however, confined to environmental measures.

\footnotetext{
${ }^{844}$ See Art. 1139 of NAFTA, cited at note 216, supra.

${ }^{845} \mathrm{D}$ Price, quoted in Been and Beauvais, supra note 583 , at 55. See, also, AlQurashi, supra note 49, at $901 \&$ note 45 at 904.

${ }^{846}$ Art. 1114 para. 1 , of NAFTA, cited at note 516 , supra.
} 
The investment provisions in NAFTA, particularly their application by arbitral panels, have strongly influenced other FTAs of the US and its recent BITs. These treaties normally include references to the four requirements for a lawful expropriation, adopt the Hull formula, and merely mention indirect expropriation and measures equivalent to it. Measure is sometimes defined. The covered investment in them comprises both tangibles and intangibles, but unlike NAFTA, the list that describes it is not exhaustive. The latest US BIT-model and its FTAs do not only follow NAFTA. They are also drafted in conformity with the guidelines of the 2002 Trade Promotion Act of the US, enacted in the wake of the award in Metalclad, while Methanex was still pending and other arbitrations threatening US interests loomed in the horizon. Section 2102 (b) (3) of this statute, on foreign investment, declares the following:

Recognizing that United States law on the whole provides a high level of protection for investment, consistent with or greater than the level required by international law, the principal negotiating objectives of the United States regarding foreign investment are to reduce or eliminate artificial or trade-distorting barriers to foreign investment, while ensuring that foreign investors in the United States are not accorded greater substantive rights with respect to investment protections than United States investors in the United States, and to secure for investors important rights comparable to those that would be available under United States legal principles and practice, by- (D) seeking to establish standards for expropriation and compensation for expropriation, consistent with United States legal principles and practice. ${ }^{847}$

This statement is remarkable. By giving foreigners in the US no greater substantive rights than its domestic investors, the father and main advocate of an absolute minimum standard of treatment in international law has adopted a relative maximum standard linked to a specific national treatment. Such a limitation goes against the system of protection established at present in most BITs and EIAs,

\footnotetext{
${ }^{847}$ The 2002 Trade Promotion Act is available at $<$ http://www.bilaterals.org/IMG/pdf/TPAA_2002.pdf> (last visited 31 March, 2008).
} 
consisting on the complementary application of the international and national principles.

The principle of non-discrimination, as both a minimum and maximum standard of treatment, was developed in Latin America by the end of the $19^{\text {th }}$ century. ${ }^{848}$ Today, the prohibition of discrimination is part of the international minimum standard advanced by the US and recognised in most treaties and several judicial decisions of international tribunals. The statement of the 2002 Trade Promotion Act is, in substance, identical to one of the principles of international law adopted by the First International Conference of American States held in 1889-90, which said:

A nation has not, nor recognizes in favour to foreigners, any other obligations or responsibilities than those which in favour of the natives are established in like cases by the constitution and the laws.

Paulsson singled out this principle as one of the early formal recognitions of the Calvo doctrine in state practice. ${ }^{849}$ The statement of the Trade Promotion Act also matches Article 9, paragraph 2, of the 1934 Montevideo Convention on the Rights and Duties of States, identified by Garcia-Amador as one of the most prominent examples of the Calvo doctrine in treaty-law. ${ }^{850}$ It is even close to the Calvo clause interpreted in North American Dredging Company of Texas, which established that:

The contractor and all persons who, as employees or in any other capacity, may be engaged in the execution of the work under this contract either directly or indirectly [...] shall not claim, nor shall they have, with regard to the interests and the business connected with this contract, any other rights or means to enforce the same than those granted by the laws of the Republic [of Mexico] to Mexicans, nor shall they enjoy any other rights than those established in favour of Mexicans. ${ }^{851}$

\footnotetext{
${ }^{848}$ Francioni, supra note 81 , at 269.

${ }^{849}$ Paulsson, supra note 82 , at 21.

${ }^{850}$ See Garcia-Amador, supra note 86, at 521.

See, also, Chapter 2 supra.

${ }^{851}$ Shea, supra note 78, at 200.
} 
A US official document employing the wording of one the most fought-upon

Latin American doctrines on the treatment of aliens surely represents a turning point in this area of international law. The reasons behind this radical change of mind in US authorities is found in the report of the Senate Finance Committee on the bill from which the Trade Promotion Act's provisions derived. As this document explains:

\begin{abstract}
one concern expressed about investment agreements currently in force is that the concept of what constitutes an expropriation may be interpreted more broadly than the concept of what constitutes a 'taking' under U.S. law. U.S. takings law has evolved through more than two centuries of decisions by the Supreme Court and lower courts. While there is no fixed set of criteria, that jurisprudence has given rise to certain guidelines, such as criteria for determining when a government regulation (as opposed to a physical appropriation of land) amounts to a compensable 'taking'. By contrast, certain complaints under NAFTA chapter 11 have urged arbitrators to find expropriations where the applicable tests under U.S. law may not support compensation for a taking. While there is unlikely ever to be a perfect overlap, and U.S. courts themselves differ on these issues, section 2 (b) (3) (D) directs negotiators to draw on the guidelines developed in U.S. takings jurisprudence in seeking to refine the concept of expropriation for purposes of international investment agreements. This should help ensure that investment agreements do not confer on foreign investors in the United States a right to compensation for expropriation that differs substantially from the right to compensation for takings that U.S. citizens already enjoy. ${ }^{852}$
\end{abstract}

After the Trade Promotion Act was enacted, the US has signed and ratified FTAs and BITs which include a description of indirect expropriation in the form of the three Penn Central factors developed in US regulatory-takings doctrine. In this way, international tribunals are guided towards a police-powers solution in those indirect takings cases where the US is involved under any of these treaties. ${ }^{853}$ Among the US treaties that include such a statement, as well as other clarifications that spring from the same doctrine, are the 2003 Chile and Singapore FTAs ${ }^{854}$; the 2004

\footnotetext{
${ }^{852}$ Quoted in Sampliner, supra note 8, at 37.

${ }^{853}$ See Fortier and Drymer, supra note 8, at 317-9; and UNCTAD, supra note 373, at 107-8. .

${ }^{854}$ See 2003 Chile-US FTA, Chapter 10, and Annexes 10-A and 10-D, cited at note 209, supra; and 2003 Singapore-US FTA, Chapter 15, and the letter exchanges on customary international law and on expropriation, available at:
} 
Australia, Central America and Dominican Republic (CAFTA-DR), and Morocco FTAs ${ }^{855}$; and the 2006 Oman FTA. ${ }^{856}$ Following the US doctrine, these treaties also exclude judicial or administrative actions from the open-ended definition of investment. Most FTAs and BITs concluded by countries other than the US have not yet included the qualifications put forward by this state in its treaty-models. ${ }^{857}$ The 2006 Panama-Singapore FTA is still an exception to this trend. ${ }^{858}$

\subsection{NAFTA arbitrations and the demise of MAI}

The protection of foreign investments from expropriation by Mexican authorities was the main concern of the US government at the moment of signing NAFTA. ${ }^{859}$ Nevertheless, the cases brought before arbitral panels under this treaty have gone on other directions too. Taking-claims have been lodged not only against Mexico, but also against Canada and the US. These actions usually refer to an

$<$ http://www.ustr.gov/Trade_Agreements/Bilateral/Singapore_FTA/Final_Texts/Section_Index.html $>$ (last visited 31 March, 2008).

${ }^{855}$ See 2004 Australia-US FTA, Chapter 11, and Annexes 11-A and 11-B, available at $<$ http://www.ustr.gov/Trade_Agreements/Bilateral/Australia_FTA/Final_Text/Section_Index.html > (last visited 31 March, 2008);

2004 CAFTA-DR, Chapter 10, and Annexes 10-B and 10-C, available at

$<$ http://www.ustr.gov/Trade_Agreements/Bilateral/CAFTA/CAFTA-

DR_Final Texts/Section_Index.html $>$ (last visited 31 March, 2008);

and 2004 Morocco-US FTA, Chapter 10, and Annexes 10-A and 10-B, available at <http://www.ustr.gov/Trade Agreements/Bilateral/Morocco_FTA/FInal_Text/Section_Index.html> (last visited 31 March, 2008).

${ }^{856}$ See 2006 Oman-US FTA, Chapter 10, and Annexes 10-A and 10-B, available at $<\mathrm{http}: / /$ www.ustr.gov/Trade Agreements/Bilateral/Oman FTA/Final Text/Section_Index.html $>$ (last visited 31 March, 2008).

${ }^{857}$ See, e.g., 2003 Mexico-Uruguay FTA, Chapter XIII, available in Spanish at $<$ http://www.sice.oas.org/Trade/mexurufta_s/Text3_s.asp\#CAPÍTULO_XIII> (last visited 31 March, 2008);

2004 Chile-South Korea FTA, Chapter 10, available in Spanish at $<$ http://www.direcon.cl/index.php?accion=tlc_corea_01_va> (last visited 31 March, 2008); and 2005 Economic Partnership Agreement between Japan and Malaysia, Chapter 7, available at $<$ http://www.mofa.go.jp/region/asia-paci/malaysia/epa/content.pdf> (last visited 31 March, 2008).

${ }^{858}$ See 2006 Panama-Singapore FTA Chapter 9, available at $<$ http://www.sice.oas.org/Trade/PAN_SGP/PAN_SGP e/Text_e.pdf> (last visited 31 March, 2008). ${ }^{859}$ Loppacher and Kerr, supra note $5 \overline{73}$, at 46. 
indirect rather than a direct expropriation, challenging the host-state's regulatory power in sensitive areas like the protection of the environment or public health, and taxation, among others. Moreover, the arbitral panels' interpretation of concepts like investment and measures, closely related to Article 1110, have expanded the scope of the protection afforded by this provision. NAFTA tribunals have gone beyond what the negotiators of the treaty originally considered an investment, regarding even a company's market share as part of this concept. ${ }^{860}$ The definition of measure in Article 201 of NAFTA has also been interpreted broadly, comprising legislative and administrative action, judicial decisions included. ${ }^{861}$

The experience of NAFTA arbitrations affected the OECD's MAI, as well as any future attempt to regulate investment in a multilateral treaty. The MAI drowned not only in the opposition of developing states, but also in the growing apprehension of developed countries and NGOs towards international claims directed against the host-state's exercise of its regulatory powers. For the first time, the treatment expected from developing countries with regards to foreign investors is demanded from developed states too. This new international context has come to threaten the network of BITs and EIAs concluded worldwide. In the past, the opposition to the international minimum standard came exclusively from second and third world countries. At present, NGOs headquartered mostly in developed states have joined their fray. In an incredible twist of events, the US government has endorsed the national treatment standard, so strongly objected by it for more than a hundred years. Such an unusual framework explains the, until not so long, unlikely fact that Canada

\footnotetext{
${ }^{860} \mathrm{G}$ Akpan, 'The Investment Provisions of the United States-Singapore Free Trade Agreement and the NAFTA. Old Wine in a New Skin or Something Else?', (2005) 6/VI JWIT 873, at 877.

${ }^{861}$ Been and Beauvais, supra note 583, at 41.

See, also, Madalena, supra note 62 , at 73.
} 
and Mexico advocated a police-powers solution to the problem of indirect takings in their written submissions to the tribunal in Methanex; a proceeding where the respondent was the US, upholding the same approach. ${ }^{862}$

\subsubsection{Two rules for one standard}

The arbitral panel that rejected the takings claim in Pope \& Talbot followed a sole-effect approach. Canada had argued that regulations constitute an exercise of police-powers which is beyond the reach of NAFTA's rules on expropriation, unless adopted in a discriminatory manner. The tribunal considered the formulation of Canada to go too far. Quoting the Third Restatement, the award declared that regulations can indeed be exercised in a way that would constitute creeping expropriation. ${ }^{863}$ A blanket exception for regulatory measures would create, it said, a "gaping loophole in international protections against expropriation" ${ }^{864}$. Nonetheless, Pope \& Talbot avoided espousing the claimant's position on the issue. The US investor had argued that the phrase "measure tantamount to nationalization or expropriation" in Article 1110 broadens the ordinary concept of takings under international law, in the sense that it would require compensation for measures affecting property without regard to the magnitude or severity of that effect. The panel rejected this contention and plainly stated: “"Tantamount' means nothing more than equivalent. Something that is equivalent to something else cannot logically

${ }^{862}$ Methanex Corporation v. United States of America, NAFTA, UNCITRAL arbitration, Final Award, 3 August, 2005, Part II, Chapter C, paras. 31-2. Available at $<$ http://ita.law.uvic.ca/documents/MethanexFinalAward.pdf> (last visited 31 March, 2008).

${ }^{863}$ Pope and Talbot. Inc. v. The Government of Canada, NAFTA, UNCITRAL arbitration, Interim Award, 26 June, 2000, para. 99. Available at <http://ita.law.uvic.ca/documents/PopeInterimAward.pdf $>$ (last visited 31 March, 2008).

${ }^{864} \mathrm{Ibid}$. 
encompass more". ${ }^{865}$ Pope \& Talbot consequently applied the test of substantial deprivation, citing both the Harvard Draft and the Third Restatement for this purpose. $^{866}$

A second NAFTA award settled an expropriation claim in 2000. Metalclad was a US investor that bought a Mexican company to develop and operate a hazardouswaste landfill located in the municipality of Guadalcazar, in the state of San Luis Potosi, Mexico. After getting authorisations from the Mexican federal state, the national ecological institute, and the state of San Luis Potosi, the claimant was refused a construction permit by the municipality of Guadalcazar. Its request for reconsideration of the denial of the permit was also rejected by the municipality, which then effectively prevented Metalclad from opening the finished landfill. The claimant unsuccessfully lodged an administrative complain, as well as a constitutional action. The governor of the state of San Luis Potosi finally issued an ecological decree declaring a natural area for the protection of a rare cactus encompassing the landfill.

The panel found a violation of Article 1110. According to it, the exclusive authority regarding a hazardous-waste landfill resided with the Mexican federal state, which permitted or tolerated the conduct of Guadalcazar in relation to Metalclad, and participated or acquiesced in the denial of its right to operate the landfill, notwithstanding the fact that the project had been fully approved and endorsed by federal authorities. As a result, Mexico's conduct amounted to a measure equivalent to expropriation in breach of NAFTA. ${ }^{867}$ Referring to Biloune, the tribunal held that

\footnotetext{
${ }^{865}$ Ibid., para. 104.

${ }^{866}$ Ibid., para. 102.

${ }^{867}$ Metalclad Corporation v. United Mexican States, NAFTA, ICSID case No. ARB(AF)/97/1, Award, 30 August, 2000, paras. 104-5. Available at
} 
the actions of the municipality effectively and unlawfully prevented the claimant's operation of the landfill. These measures, together with the representations of the Mexican federal government, on which Metalclad had relied, "and the absence of a timely, orderly or substantive basis for the denial by the Municipality of the local construction permit", were equivalent to an indirect taking. The ecological decree of the governor of the state of San Luis Potosi was considered by the tribunal as a further ground for a finding of expropriation. ${ }^{868}$ Metalclad based its conclusions in one of the most famous statements of the sole-effect doctrine in international caselaw:

expropriation under NAFTA includes not only open, deliberate and acknowledged takings of property, such as outright seizure or formal or obligatory transfer of title in favour of the host State, but also covert or incidental interference with the use of property which has the effect of depriving the owner, in whole or in significant part, of the use or reasonably-to-be-expected economic benefit of property even if not necessarily to the obvious benefit of the host State. ${ }^{869}$

A third decision rejected a takings claim before the end of 2000 , implicitly endorsing the sole-effect rule. S.D. Myers declared that:

The general body of precedent usually does not treat regulatory action as amounting to expropriation. Regulatory conduct by public authorities is unlikely to be the subject of legitimate complaint under Article 1110 of the NAFTA, although the Tribunal does not rule out that possibility. ${ }^{870}$

The panel differentiated expropriations from regulations in their effects: the former tends to involve the deprivation of ownership right, while the latter a lesser interference ${ }^{871}$. S.D. Myers accepted the possibility of partial or temporary takings, and agreed with Pope \& Talbot's conclusion that the phrase "measure tantamount to"

\footnotetext{
$<$ http://ita.law.uvic.ca/documents/MetacladAward-English.pdf> (last visited 31 March, 2008).

${ }^{868}$ Ibid., paras. $106-9 \& 111$.

${ }^{869} \mathrm{Ibid}$., para. 103.

${ }^{870}$ S.D. Myers, Inc. v. The Government of Canada, NAFTA, UNCITRAL arbitration, Partial Award, 13 November, 2000, para. 281. Available at

$<$ http://ita.law.uvic.ca/documents/SDMeyers-1 stPartialAward.pdf> (last visited 31 March, 2008).

${ }^{871}$ Ibid., para. 282.
} 
means "equivalent to", adding that the drafters of NAFTA intended the word "tantamount" to embrace the concept of creeping expropriation, "rather than to expand the internationally accepted scope of the term expropriation". ${ }^{872}$

Two years later, the arbitral panel in Feldman turned down another expropriation claim. As in Metalclad and S.D. Myers, the tribunal adopted the soleeffect doctrine. It said:

If there is a finding of expropriation, compensation is required even if [sic] the taking is for a public purpose, non-discriminatory and in accordance with due process of law and Article 1105(1) [on FET, and full protection and security]. ${ }^{873}$

The award explained the difference of regulation and indirect takings by

formulating a police-powers exception from a sole-effect standpoint:

The Tribunal notes that the ways in which governmental authorities may force a company out of business, or significantly reduce the economic benefits of its business, are many. In the past, confiscatory taxation, denial of access to infrastructure or necessary raw materials, imposition of unreasonable regulatory regimes, among others, have been considered to be expropriatory actions. At the same time, governments must be free to act in the broader public interest through protection of the environment, new or modified tax regimes, the granting or withdrawal of government subsidies, reductions or increases in tariff levels, imposition of zoning restrictions and the like. Reasonable governmental regulation of this type cannot be achieved if any business that is adversely affected may seek compensation, and it is safe to say that customary international law recognizes this. ${ }^{874}$

The panel relied heavily on the Third Restatement and its comments to this

respect. Feldman referred also to Azinian, when it stated that:

not all government regulatory activity that makes it difficult or impossible for an investor to carry out a particular business, change in the law or change in the application of existing laws that makes it uneconomical to continue a particular business, is an expropriation under Article 1110. Governments, in their exercise of regulatory power, frequently change their laws and regulations in response to changing economic circumstances or changing political, economic or social

${ }^{872}$ Ibid., paras. $283 \&$ 285-6.

See, also, Been and Beauvais, supra note 583, at 52-3; Sampliner, supra note 8, at 6; Shenkman, supra note 804 , at 177-8; and Newcombe, supra note 50, at 22-3.

${ }^{873}$ Marvin Feldman v. Mexico, NAFTA, ICSID Case No. ARB(AF)/99/1, Award, 16 December, 2002, para. 98. Available at

$<$ http://ita.law.uvic.ca/documents/feldman_mexico-award-english.pdf> (last visited 31 March, 2008).

${ }^{874}$ Ibid., para. 103. 
considerations. Those changes may well make certain activities less profitable or even uneconomic to continue. ${ }^{875}$

Regarding the phrase "measure tantamount to nationalization or expropriation", the award followed Pope \& Talbot and S.D. Myers. ${ }^{876}$ On the level of interference necessary to amount to an expropriation, the tribunal quoted Metalclad, but had its doubts as to whether the lack of transparency alone rises to the level of a violation of NAFTA and international law. ${ }^{877}$

The claimant in GAMI was not successful either. According to the panel in this case, Pope \& Talbot may suggest that the "impairment" of the value of the property of an investor would not be equivalent to its taking. ${ }^{878}$ Quoting not only S.D. Myers and Metalclad, but also TAMS and Santa Elena, the tribunal supported the proposition that the partial destruction of the value may amount to expropriation. ${ }^{879}$ A NAFTA tribunal embraced the police-powers rule a year later. In Methanex, a Canadian investor in the US claimed compensation for the losses caused by the state of California's ban on the sale and use of a gasoline additive, to which its main product was a feedstock. Methanex alleged damages to "a substantial portion of [its] customer base, goodwill, and market for methanol in California", as a result of the ban. ${ }^{880}$ On this regard, the award agreed with Pope \& Talbot's broad concept of property. Nevertheless, it concluded that items such as goodwill and market share may figure in the valuation of a comprehensive taking, "[b]ut it is difficult to see

\footnotetext{
${ }^{875}$ Ibid., para. 112.

${ }^{876} \mathrm{Ibid}$, para. 100.

See, also, Fortier and Drymer, supra note 8, note 10 at 297; and Kunoy, supra note 51, at 475-6.

${ }^{877}$ Marvin Feldman case, supra note 873, paras. 133 \& 145.

${ }^{878}$ GAMI Investments, Inc. v. The Government of the United Mexican States, NAFTA, UNCITRAL arbitration, Award, 15 November, 2004, para. 128. Available at

$<$ http://ita.law.uvic.ca/documents/Gami.pdf > (last visited 31 March, 2008).

${ }^{879}$ Ibid., para. 131.

${ }^{880}$ Methanex Corporation case, supra note 862, Part IV, Chapter A, para. 2.
} 
how they might stand alone, in a case like the one before the Tribunal". ${ }^{881}$ The tribunal considered the taking-claim within the limits of the phase "measure tantamount to" expropriation, and analysed it from a police-powers perspective, worded in these terms:

as a matter of general international law, a non-discriminatory regulation for a public purpose, which is enacted in accordance with due process and, which affects, inter alios, a foreign investor or investment is not deemed expropriatory and compensable unless specific commitments had been given by the regulating government to the then putative foreign investor contemplating investment that the government would refrain from such regulation. ${ }^{882}$

This statement limits indirect takings to those measures that go against specific commitments made by the host-state to the foreign investor. The panel quoted Revere Cooper and Waste Management on the issue of a government's assurances, representations or undertakings given to aliens, but forgot that compensation is one of the requirements of a lawful expropriation under international law. ${ }^{883}$ In the tribunal's declaration, public purpose, non-discrimination, and due process of law are the elements that differentiate a regulation from an indirect taking, rather than conditions of a lawful one. Although the panel starts its statement by saying "as a matter of general international law", such an interpretation owes more to the US regulatory-takings doctrine than to international norms. At the end, the tribunal found that no commitments were given to Methanex by the host-state. It declared that the California ban was made for a public purpose, was non-discriminatory and followed a due process. The panel concluded that "[f]rom the standpoint of international law, the California ban was a lawful regulation and not an expropriation". ${ }^{884}$

\footnotetext{
${ }^{881}$ Ibid., Part IV, Chapter D, para. 17.

${ }^{882}$ Ibid., Part IV, Chapter D, para. 7.

${ }^{883}$ Ibid., Part IV, Chapter D, para. 4.

${ }^{884}$ Ibid., Part IV, Chapter D, paras. $9 \& 15$.
} 


\subsubsection{A good idea wrongly executed}

The MAI's negotiations took place within the OECD between 1995 and 1998, when the first NAFTA arbitrations were being settled. More precisely, among its then 29 members, mostly developed states ${ }^{885}$, and the Commission of the European Community. 8 non-OECD members participated only as observers. ${ }^{886}$ Other nonOECD members were informed on a regular basis about the status and substance of the negotiations. The MAI had been planned as a multilateral treaty open to all OECD members and non-OECD members, based on three pillars: investment liberalisation, investment protection, and dispute settlement. ${ }^{887}$ It followed, and improved, the investment protections of NAFTA and the ECT ${ }^{888}$ BITs, modelled on the 1967 OECD Draft Convention, were also an important source for the international minimum standard included in it. The MAI had a clear leaning towards foreign investors and was promoted as an effort to transform these protections into multilateral rules, with some additional provisions. ${ }^{889}$ The concept of property included in its consolidated text was broad. ${ }^{890}$ Chapter II, Article 2, defined investment as every kind of asset owned or controlled, directly or indirectly, by an alien. Some OECD members and NGOs expressed their concerns over the inclusion

\footnotetext{
${ }^{885}$ Australia, Austria, Belgium, Canada, Czech Republic, Denmark, Finland, France, Germany, Greece, Hungary, Iceland, Ireland, Italy, Japan, Korea, Luxembourg, Mexico, Netherlands, New Zealand, Norway, Poland, Portugal, Spain, Sweden, Switzerland, Turkey, UK, and the USA.

${ }^{886}$ Argentina, Brazil, Chile, Estonia, Hong Kong, China, Latvia, Lithuania, and the Slovak Republic. The latter is today a member of OECD.

${ }^{887}$ Sacerdoti, supra note 8, at 293-4, and Matsushita, Schoenbaum and Mavroidis, supra note 746, at 536.

${ }^{888}$ Waelde and Kolo, supra note 8 , at 816.

${ }^{889}$ Muchlinski, supra note 639 , at 1036 \& 1038.

${ }^{890}$ MAI, Draft Consolidated Text, DAFFE/MAI(98)7/REV1, 22 April 1998, available at <http://www1.oecd.org/daf/mai/pdf/ng/ng987rle.pdf> (last visited 31 March, 2008).
} 
of investments indirectly owned. ${ }^{891}$ An interpretative note was added to this provision, stating that in order to qualify as an investment under the MAI, "an asset must have the characteristics of an investment, such as the commitment of capital or other resources, the expectation of gain or profit, or the assumption of risk". ${ }^{892}$ The definition was followed by an illustrative list, including tangibles and intangibles in wide terms. Portfolio investment and FDI were protected, and the commentary to the consolidated text explained that this exemplary list of assets covered "all recognised and evolving forms of investment". 893

Chapter IV, Article 2, was the expropriation provision. It protected foreign investments against direct and indirect takings, as well as "any measure or measures having equivalent effect". The four requirements of a lawful taking, normally found in BITs and EIAs, were mentioned in this provision. The first one was described as "a purpose which is in the public interest". According to the commentary, the terms "public purpose" and "public interest" have similar meanings, but derive from different legal traditions. The wording chosen was considered to be consistent with them. ${ }^{894}$ Chapter IV, Article 2, employed the Hull formula at the moment of describing the payment of compensation, and due process was construed as expressly including the judicial review of the expropriatory measure by a competent and independent authority of the host-state.

Concerns over the limits of indirect takings led to an explicative note in the commentary to this provision, stating that the violation of criminal laws resulting in

\footnotetext{
${ }^{891}$ Picciotto, supra note 748, at 755-6; M Vallianatos, 'De-Fanging the MAI', (1998) 31 Corn. ILJ 713, 714-5; and Muchlinski, supra note 639, at 1041.

${ }^{892}$ MAI, Draft Consolidated Text, note 2 at 11.

See note 890, supra.

${ }^{893}$ MAI, Commentary to the Consolidated Text, DAFFE/MAI(98)8/REV1, 22 April 1998, available at $<$ http://wwwl .oecd.org/daf/mai/pdf/ng/ng988rle.pdf> (last visited 31 March, 2008).

${ }^{894}$ Ibid., para. 1, at 30.
} 
the total or partial loss of an investment would not be deemed an expropriation, "provided those laws and their application are non-discriminatory and otherwise consistent with the standards of this agreement". ${ }^{895}$ This approach conforms to the police-powers exception acknowledged by the sole-effect doctrine. The 1998 report by the Chairman of the negotiating group added that the takings provision was intended to incorporate into the MAI existing international norms, and that the reference to expropriation or nationalisation, and measures tantamount to either, reflected the fact that international law requires compensation for a taking without regard to the label applied to it, even if the title to the property is not taken. In other words, as the report said, it did not establish "a new requirement that Parties pay compensation for losses which an investor or investment may incur through regulation, revenue raising and other normal activity in the public interest undertaken by governments" ${ }^{896}$ A declaration adopted by the OECD Council of Ministers that same year further stated that "the MAI would establish mutually beneficial international rules which would not inhibit the normal non-discriminatory exercise of regulatory powers by governments and such exercise of regulatory powers would not amount to expropriation". 897

The commentary to the consolidated text explained that the phrase "measure or measures having equivalent effect" meant, in general, creeping expropriation. ${ }^{898}$ Regarding the practical consequence of distinguishing between a lawful and an unlawful taking, it said that the former would be subject to the Hull formula, while

\footnotetext{
${ }^{895} \mathrm{Ibid}$., para. 2, at 30 .

${ }^{896}$ MAI, Report by the Chairman of the Negotiating Group, DAFFE/MAI(98)17, 4 May 1998, note 2 at 13, available at <http://www1 .oecd.org/daf/mai/pdf/ng/ng9817e.pdf> (last visited 31 March, 2008). See, also, Graham, supra note 802, at 611.

${ }^{897}$ Yannaca-Small, supra note 306 , at 9.

${ }^{898}$ MAI, Commentary to the Consolidated Text, para. 5, at 30.

See note 893, supra.
} 
the latter would give rise to a right of restitution under customary law. ${ }^{899}$ Such a view is not found expressly stated in BITs or EIAs, but has been endorsed in doctrine. ${ }^{900}$ To effectively protect the property of aliens, the MAI included a dispute settlement device for investor-to-state controversies. Chapter V gave the investor the choice, commonly found in BITs and some EIAs, to submit the respective controversy to the domestic courts or administrative tribunals of the host state, or to international arbitration under ad hoc, ICSID, UNCITRAL, or the ICC rules.

Though the protection of foreign investment in the MAI was not particularly new in international law, it failed in the end mainly for the lack of a representative body of states in the negotiations that undermined the global character of the draft treaty. ${ }^{901}$ One of the main reasons for the adoption of the MAI was to liberalise and protect foreign investment in developing countries. However, these states were not adequately represented in the negotiating process from the beginning. The OECD, rather than the World Bank or the World Trade Organization, was not the best forum for drafting such a multilateral treaty. On the other hand, NGOs resented not being invited to participate in the negotiations and criticised the secretiveness of the whole process. ${ }^{902}$ In this context, the clear inclination of the MAI towards foreign investors, derived from BITs and EIAs, became suspicious and a prime target of criticism for developing states and NGOs, which related the treaty with the widespread antiglobalisation campaigning against international economic organisations. ${ }^{903}$ The growing opposition even distressed European governments, eager not to upset their

\footnotetext{
${ }^{899}$ Ibid., para. 6, at 30.

${ }^{900}$ See Chapter 1 supra.

${ }^{901}$ See Juillard, supra note 579, at 478-9; Picciotto, supra note 748, at 741-2; Muchlinski, supra note 639, at 1039; and R Geiger, 'Regulatory Expropriations in International Law: Lessons from the Multilateral Agreement on Investment', (2003) 11 NYU ELJ 94, at 98.

${ }^{902}$ E.g., the consolidated negotiating text was a restricted internal document of the OECD, only published in the internet in 1997, after it was leaked out

${ }_{903}$ Waelde and Kolo, supra note 8, at 816; and Sornarajah, supra note 3, at 3-4.
} 
electorates. ${ }^{904}$ The timing of the MAI was also not the best. At the end of the $1990 \mathrm{~s}$, claims of indirect takings were lodged against developed countries in the context of NAFTA. Ethyl and Metalclad, for instance, affected the negotiations. ${ }^{905}$ There were other problems too. For example, the right of entry and establishment, borrowed from NAFTA and US BITs, was only accepted with significant general and countryspecific exceptions, resulting in what was called a "Swiss cheese" agreement. ${ }^{906}$ Several countries had expressed their concern to the liberalisation of the media sector to foreign investment, fearing an "Americanisation" of this industry. The cultural exception to the national treatment standard of the MAI became a deal breaker for these states, particularly to France. ${ }^{907}$ Eventually, it was the Prime Minister of this country, Lionel Jospin, who declared in 1998 that his government would take no further part in the negotiations of the MAI. Few days later, the OECD announced that it would not proceed with them. ${ }^{908}$

\subsection{Conclusion}

The attempts to regulate expropriation in a multilateral treaty span from the beginning of the $20^{\text {th }}$ century to its end. Various instruments emerged from these efforts. Early ones, like the 1949 ICC Code of Fair Treatment for Foreign

\footnotetext{
${ }^{904}$ Sornarajah, supra note 3, at 292.

${ }^{905}$ See Been and Beauvais, supra note 583, at 35-6; Geiger, supra note 901, at 96-7; Sornarajah, supra note 3, at 293; UNCTAD, supra note 19, at 241-2; Akpan, supra note 860, at 874; and Newcombe, supra note 50 , at $1-3$.

See, also, Ethyl Corporation v. The Government of Canada, NAFTA, UNCITRAL arbitration, Award, 24 June 1998, available at $<$ http://ita.law.uvic.ca/documents/Ethyl-Award.pdf $>$ (last visited $31 \mathrm{March}$, 2008); and Metalclad Corporation case, supra note 867.

${ }_{907}^{906}$ Picciotto, supra note 748, at 760; and Muchlinski, supra note 639, at 1042.

${ }_{907}^{902}$ Sallianatos, supra note 891, at 718-9; and Muchlinski, supra note 639, at 1948.

${ }^{908}$ See Muchlinski, supra note 639, 1048-9; and Geiger, supra note 901, at 95-6.
} 
Investments or the 1959 Abs/Shawcross Draft Convention on Investments Abroad, implicitly or explicitly recognised the international minimum standard and briefly referred to takings. The first of these instruments to adopt an open police-powers approach was the 1967 OECD Draft Convention. Its text was highly influential in the BITs subsequently concluded by Western European states. Nevertheless, none of these countries followed in their treaties the police-powers solution included in the commentary of the OECD Draft. Inspired on the domestic takings doctrine of the US, the 1961 Harvard Draft and the 1987 Third Restatement also adopted a policepowers rule regarding the issue of indirect expropriation. The 1990 UN Draft Code of Conduct of TNCs and the 1992 World Bank Guidelines on the Treatment of Foreign Direct Investment, followed the traditional requirements of a lawful expropriation, but did not refer expressly to the problem of intent in indirect takings.

Multilateral treaties that mention or regulate expropriation, effectively concluded and in force today, have usually not adopted either a sole-effect or a police-powers solution in explicit terms. The 1985 MIGA did opt for the sole-effect rule, but neither the 1987 ASEAN Agreement nor the 1992 ECT are openly inclined to any of these two approaches. The 1992 NAFTA is silent on the issue too. Not its case-law, however. The protections included in NAFTA, originally aimed at guaranteeing the investments of nationals of Canada and the US in Mexico, have also been used by aliens in the former countries, thus challenging regulatory measures adopted by developed states. Arbitral panels established under Chapter 11 of NAFTA have generally approached the question of indirect takings from a soleeffect perspective. Examples of this solution can be found in Pope \& Talbot, Metalclad, S.D. Myers, and Feldman. The police-powers rule followed by the 
tribunal in Methanex is still an exception to this trend, though an exception whose impact is still felt throughout the international society.

The response of the US to the threat posed by international claims directed against it, within the context of the sole-effect approach endorsed by NAFTA awards, was made official in the 2002 Trade Promotion Act. After this statute, BITs and FTAs concluded by the US have incorporated its domestic takings doctrine, expressly naming the Penn Central factors as a guideline to decision-makers facing claims of indirect expropriation. The international minimum standard, the US flagship in its approach to the protection of aliens under the law of nations, has been replaced by a national treatment standard limited to that granted by the US to those foreigners investing within its territory. By modifying its latest BIT model version, Canada has followed on the footsteps of the US. These efforts to introduce the police-powers rule in international law has been well-received by those developing countries involved in BIT or EIA arbitrations. NGOs, mainly those concerned with the protection of the environment, have joined this heterogeneous group favouring the police-powers rule. As a consequence, the future of the international minimum standard, and the sole-effect solution to the threshold question that forms part of it, seems more uncertain that ever. 


\section{FROM TAKINGS TO FAIR AND EQUITABLE TREATMENT}

The international law of expropriation has a long history, much longer than that of international investment law, the branch to which it currently belongs. In the past, the debate on takings was centred on the problem of compensation. It was not until the second half of the $20^{\text {th }}$ century that the concept of indirect expropriation came to the fore, relegating the issue of compensation to a second place of importance. The network of BITs and EIAs recently concluded and currently in force explains this new state of affairs. The exercise of the host-state's regulatory power can be challenged today by a foreign investor under the settlement provisions of these treaties. International tribunals have generally felt uncomfortable looking at in the intention of the host-state behind the adoption of its sovereign measures. As a consequence, the police-powers doctrine has rarely been followed by judges and arbitrators at the moment of establishing the limits between non-compensable measures and indirect takings. The sole-effect rule, conversely, has provided a clear guideline which allows decision-makers to abstain from such an exercise when faced with this thorny question. For this reason, it has been generally adopted in international case-law.

The US and European states upheld the sole-effect rule when its application was restricted to African, Asian, and Latin American countries. Now, that any hoststate can see its regulatory policy challenged by an expropriation claim, it has fallen into disgrace. Not just developing countries and NGOs favour a police-powers rule at 
present, then: developed states have started to support it too. But does this solution conform to the international law of expropriation? The potential application of the police-powers rule has compounded the uncertainty that surrounds the application of the international norms on expropriation. To avoid being left with no compensation, claimants have turned to another dormant provision in investment treaty law: the FET clause. The strategy is simple. Confronted with an eventual reluctance of arbitrators to award compensation for a taking, foreign investors add to their claims alleged breaches to other treaty protections. The FET provision is usually mentioned among these. The aim of the claimants is to obtain compensation for lesser interferences. That is to say, for those measures affecting property which do not amount to an expropriation. The ubiquity of the FET clause in current investment arbitration is such that the focus in international investment law has begun to shift once again. This time, from the problem of indirect takings to that of FET.

The present chapter assesses the sole-effect/police-powers debate from the standpoint of international law. It also deals with other compensable measures under investment treaties. Particularly, FET -its origin, meaning, and scope. The study of the constitutive elements of this protection is followed by that of the relation between FET and the minimum standard in customary international law. The boundaries of indirect takings and FET, as well as the interaction of the two concepts, are analysed as well.

\subsection{Changes in international case-law}

Schreuer recalls that "[e]ven before the introduction of pertinent treaty provisions, international courts and tribunals have treated indirect takings and 
equivalent measures in the same way as direct expropriations". ${ }^{909}$ These tribunals, however, rarely addressed this question before the 1980s. For years, the only clear references to the international law of expropriation were found in the Norwegian Shipowners claim and the Oscar Chinn case, regarding indirect takings, and the Chorzow Factory case, concerning restitution and compensation. ${ }^{910}$ It was not until the 1970 s that international tribunals dealt with this area of law again. The Libyan oil concession cases and the Aminoil arbitration illustrated the uncertainties that surrounded the question of nationalisation and its compensation. ${ }^{911}$ Nonetheless, they did not refer to indirect takings.

The problem of expropriation came before the ICJ in the Anglo-Iranian Oil Co. and the Barcelona Traction cases, but the substantive matter remained undecided due to lack of jurisdiction. ${ }^{912}$ It reappeared in the ELSI case, where a claim of disguised expropriation was rejected. Once again, the ICJ avoided giving any insight on the issue, concluding that the alleged deprivation could not be attributed to the state authorities. ${ }^{913}$ By then, the European Court of Human Rights and the Iran-US CT had already started settling expropriation claims. Their decisions originated the first comprehensive case-law on takings available in international law. In the

\footnotetext{
${ }^{909} \mathrm{C}$ Schreuer, 'The Concept of Expropriation under the ECT and other Investment Protection Treaties', in C Ribeiro (ed.), Investment Arbitration and the Energy Charter Treaty (2006), at 115.

${ }^{910}$ See Norwegian Shipowners case, supra note 425; Oscar Chinn case, supra note 425; and Factory at Chorzow case, supra note 24.

${ }^{911}$ See British Petroleum Exploration Co. v. Libyan Arab Republic, Lagergren, sole arbitrator, Award, 10 October, 1973, (1973) 53 ILR 297; Texas Overseas Petroleum Co. \& California Asiatic Oil Co. (Topco/Calasiatic) case, supra note 120; Libyan American Oil Co. v. Libyan Arab Republic, Mahmassani, sole arbitrator, Award, 12 April 1977, (1981) 20 ILM 1; and American Independent Oil Co.(Aminoil) case, supra note 521.

See, also, R von Mehren and P Kourides, 'International Arbitration Between States and Foreign Private Parties: The Libyan Nationalization Cases', (1981) 75 AJIL 476; and Norton, supra note 77, at 479-82.

${ }^{912}$ See Anglo-Iranian Oil Co. (UK v. Iran), International Court of Justice, Judgment, 22 July, 1952, available at <http://www.icj-cij.org/docket/files/16/1997.pdf> (last visited 31 March, 2008); and Barcelona Traction case, supra note 43.

${ }^{913}$ See Elettronica Sicula S.p.A. (ELSI) case, supra note 12, para 119.
} 
following years, arbitral panels established under the dispute settlement provision of investment codes, investment agreements, BITs and EIAs, would further enlarge this jurisprudence.

\subsubsection{National agendas, comparative solutions}

Judges and arbitrators facing claims of indirect expropriation apply the sources of international law described in Article 38 of the Statute of the ICJ. For this purpose, they resort to the judicial decisions of other international tribunals, as a subsidiary mean for the determination of the rules of law. Judgments of the European Court and the Iran-US CT have therefore influenced the awards of ad hoc and ICSID panels. Sornarajah calls this process cross-fertilisation. In investment treaty arbitration, it derives from the fact that many of the members of tribunals settling controversies have already sat in the Iran-US CT or other arbitral panels dealing with investment disputes. This trend has been strengthened by the publication and ready availability of judicial decisions, the growing esprit de corps among arbitrators, and a body of law predisposed to development by case-law. ${ }^{914}$

No jurisprudence constante arises out of these intertwined decisions, however. It is not only the different jurisdiction of international tribunals that prevents judges and arbitrators from giving a structured response to the problem of indirect takings. ${ }^{915}$ It is also the ad hoc nature of most of the tribunals dealing with

\footnotetext{
914 See J Commission, 'Precedent in Investment Treaty Arbitration. A Citation Analysis of a Developing Jurisprudence', (2007) 24/II JIA 129, at 135-42.

${ }^{915}$ See Sornarajah, supra note 3 , note 6 at $317, \& 351$.

See, also, Pellonpää and Fitzmaurice, supra note 8, at 56; and C Gibson and C Drahozal, 'Iran-United States Tribunal Precedent in Investor-State Arbitration', (2006) 23/VI JIA 521.
} 
expropriation claims and the system of res judicata in international law which cause this situation. ${ }^{916}$ More precisely, the lack of a system of stare decisis -i.e. one that abides by precedents. ${ }^{917}$ The principle of res judicata is a feature of the ICJ, as well as of the European Convention on Human Rights, the Iran-US CT, and ad hoc and ICSID arbitration. While Article 59 of the ICJ Statute provides that the decisions of the Court has no binding force except between the parties and in respect of that particular case, Article 53 (1) of the Washington Convention declares that the award of ICSID panels is only binding on the parties to the investment dispute. The principle of res judicata is also established, with different wording, in Article 44 and 46 (1) of the European Convention; Article IV of the 1981 Claims Settlement Declaration, establishing the Iran-US CT; and Art. 32 (2) of the 1976 UNCITRAL Arbitration Rules. ${ }^{918}$

In spite of these provisions, international tribunals normally consider the judicial decisions of other tribunals as authoritative statements, giving them great weight in practice. ${ }^{919}$ Judges and arbitrators refer and quote regularly the judicial decisions of other international tribunals to a degree unseen in domestic jurisdictions were the principle of res judicata is also applied. The steady reliance on case-law by arbitrators in international investment disputes has derived in what has been called a soft-precedent jurisprudence. ${ }^{920}$ Regarding the question of indirect takings, this jurisprudence has resorted largely to a sole-effect solution, not only in the Iran-US

\footnotetext{
${ }^{916}$ B Kunoy, 'The Notion of Time in ICSID's Case Law on Indirect Expropriation', (2006) JIA 337, at 337.

${ }^{917} \mathrm{~J}$ Trayner, Latin Maxims and Phrases (1986), 585.

${ }^{918}$ The 1976 UNCITRAL Arbitration Rules are available at $<$ http://www.uncitral.org/pdf/english/texts/arbitration/arb-rules/arb-rules.pdf > (last visited 31 March, 2008).

${ }^{919}$ See Boyle and Chinkin, supra note 54, at 293-300.

${ }^{920}$ Commission, supra note 914 , at 142.
} 
CT, ad hoc and ICSID arbitral panels, but also in NAFTA arbitrations. ${ }^{921}$ The policepowers rule adopted in Methanex, and later in Saluka, cast a shadow of doubt over such a trend.

Sornarajah recognises three moments in the post-colonial protection of aliens in international law:

In [the first] period, there was an effort to construct theories [...] which sought to remove the foreign investment process from the scope of the host state's control. [...] The second phase was the reaction of the host states to these attempts through the efforts to relocalise the process. In this period, the host states articulated norms like permanent sovereignty over natural resources and the competing standard of appropriate compensation for nationalisation [and the NIEO] [...] The third phase is one of accommodation of these principles through efforts to make bilateral investment treaties which set out the rules of investment protection as between the parties to these treaties. ${ }^{922}$

These periods cover the establishment of the international minimum standard, its challenge by the national treatment standard, and the interaction of the two principles in treaties that enshrine, in practice, the supremacy of the former over the latter. But, as the same author admits, "[i]n international life, nothing seems final. It would be brash to say that one regime has had a final triumph over another" ${ }^{923}$ So there is now a fourth period, heralded by the attempt of the US to transform international minimum standard into a national one. An essential part of this attempt is the support of the police-powers approach over the sole-effect rule.

Although the police-powers doctrine dates back to the Oscar Chinn case, it was not until NAFTA arbitrations challenged regulatory measures in the US that it became a serious contender to its more traditional counterpart, the sole-effect rule. The undefined terms of indirect expropriation and measures tantamount to it, once promoted by US negotiators and drafters, opened the door to a bulk of regulatory-

\footnotetext{
${ }^{921}$ See Chapters 4, 5 \& 6 supra.

${ }^{922}$ Sornarajah, supra note 68 , at 62 .

${ }^{923}$ Ibid., 52.
} 
taking claims. ${ }^{924}$ As Sands claims, "[t]he rules which were intended to constrain others became constraining of their creators". ${ }^{925}$ Because amending treaties is more difficult than modifying domestic legislation, this situation has gained some permanence. $^{926}$ The US reacted to it by discarding the position on the treatment of aliens that its authorities had previously defended for more than a century in the international fora. In Sands words:

The US is belatedly recognizing that foreign investment is a two-way street, and that the US too is vulnerable to challenge. This is forcing a rethink as to the real purpose of the international rules on expropriation. ${ }^{927}$

This reaction must be seen within the broader context of the relations of the US and the law of nations, for this deflection from well-accepted and frequently-observed norms currently involves other areas of international law too. Particularly, trade law; the protection of the environment; international criminal law; the use of force; and international humanitarian law. ${ }^{928}$ Other developed countries have joined the US in its attempt to replace the sole-effect approach for a police-powers rule. These states, like the US, had accepted the application of the international minimum standard and the sole-effect rule in the past, when investment disputes referred to the implementation of treaty provisions in favour of their nationals investing in developing countries.

The uncertainty produced by this new scenario is worsened by the implicit, and sometimes explicit, endorsement given by some NGOs and developing states to the US and other developed countries. These NGOs have formed an unexpected alliance with mainly capital-exporting, pro-globalisation governments. Each part,

\footnotetext{
${ }^{924}$ Been and Beauvais, supra note 583 , at $120 \& 128$.

${ }^{925}$ P Sands, Lawless World. America and the Making and Breaking of Global Rules (2005), xi.

${ }^{926}$ Been and Beauvais, supra note 583, at 138-9.

927 Sands, supra note 925 , at 141.

See, also, Sornarajah, supra note 3 , at 26.

${ }^{928}$ See, in general, Sands, supra note 925.
} 
nevertheless, approaches the issue from different angles. While NGOs are concerned about sustainable development and the protection of the environment, among other things, developed states care about the encroachment of their sovereignty. Developing countries also fear a diminution in their regulatory powers. These states are normally weak and very sensitive to any threat to their already limited sovereignty. More so, when it involves a potential confrontation with affluent TNCs.

The factual association among developed and developing states and NGOs gives more weight to the claim of the US, for it adds a much needed touch of legitimacy to the attempt of replacing the international standard for the national treatment offered by its domestic legislation. With or without NGOs and developing states, nevertheless, an important caveat should be made. Been and Beauvais expressed it in the following terms:

even if it were possible to tie international compensation requirements to U.S. takings jurisprudence, this would not be a desirable solution from an international standpoint. [A]ny effort simply to equate NAFTA's Chapter 11 with the Fifth Amendment would ignore differences between domestic and international contexts that render the reasons for affording regulatory takings protections within any given country inapplicable in the context of international investment agreements. ${ }^{929}$

The same caveat which is applicable to the translation of domestic solutions to international problems is also pertinent regarding the indiscriminate translation of concepts advanced by one international tribunal to another. ${ }^{930}$ These courts and arbitral panels are born and exist within a certain context: that provided by their respective constituent treaty. From this perspective, not only the attempt of the tribunal in TECMED to bring some of the factors of the US doctrine to international investment law must be rejected. Its intention to transfer the fair balance test of

\footnotetext{
${ }^{929}$ Been and Beauvais, supra note 583, at 141 . See, also, Shenkman, supra note 804 , at 180-2 \& 196-7.

${ }^{930}$ See Paulsson and Douglas, supra note 8 , at 147-8.
} 
European human rights law to this branch of international law, followed later by Azurix and $L G \& E$, must also be discarded..$^{931}$ The principle of proportionality was developed by the European Court of Human Rights within the three-rule system of Article 1 of the First Protocol. The possibility of distinguishing among lesser interferences, controls of the use, and deprivations of property is simply not available in the international law of expropriation, as it stands today.

The same reasoning is applicable to Kriebaum's version of the proportionality principle. Inspired in the case-law of the European Court, Kriebaum has suggested an alternative to what she calls the "all or nothing" paradigm in international investment law. This paradigm requires full compensation for an indirect taking, leaving the tribunal "no discretion to apportion the economic burden resulting from the measure between the investor and the State". ${ }^{932}$ In her opinion, the application of the proportionality principle would allow investment panels to give property-owners less compensation than the fair market value, if there is a special interest of the host-state to interfere and, at the same time, this causes no excessive burden for the individual. ${ }^{933}$ The difference between TECMED's solution and Kriebaum's is that, while the former applied the balance test at the moment of establishing whether a taking had occurred, the latter applies it at the moment of establishing the amount of compensation due. ${ }^{934}$ But Kriebaum forgets that most BITs and EIAs currently provide for a prompt, adequate and effective compensation or other formulas similar to Hull's. And modifying this large network of treaties is not an easy task, for it involves across-the-board negotiations throughout the international society.

\footnotetext{
${ }^{931}$ See Chapter 5 supra.

${ }^{932}$ Kriebaum, supra note 35 , at 720 .

933 Ibid., 730.

${ }^{934}$ Ibid., 728-30 \& 744.
} 


\subsubsection{The problems of intention and degree}

The concept of sovereignty still lies at the heart of the law of nations. In the often-quoted passage of the Isle of Palmas case, Judge Huber equated sovereignty with independence, defining it as the right to exercise the functions of a state within a portion of the globe, to the exclusion of any other state. ${ }^{935}$ Based on this notion, international tribunals will normally not question the public purpose requirement claimed by a host-state, except in the most evident cases of abuse. ${ }^{936}$ According to the Third Restatement, "[p]resumably, a seizure by a dictator or oligarchy for private use could be challenged under [the public purpose] rule". ${ }^{937}$ Letco offers a good example of an evident case of abuse. This arbitration referred to the successive reduction of the territorial scope of a concession by Liberia, which the tribunal concluded to have "the effect of greatly reducing the concession area and of effectively rendering the investment by LETCO useless". ${ }^{938}$ No public purpose was found in the measures adopted by the host-state. On the contrary, "evidence was given to the Tribunal that areas of the concession taken from LETCO were granted to other foreign owned companies [ran] by people who were 'good friends' of the Liberian authorities". 939 Most expropriation cases, however, do not present such an open disregard for this requirement.

\footnotetext{
${ }^{935}$ Isle of Palmas (The Netherlands v. US), Huber, sole arbitrator, Award, 4 April, 1928, (1928) 2 RIAA 829, at 838 .

${ }^{936}$ See G White, Nationalisation of Foreign Property (1961), 146; Pellonpää and Fitzmaurice, supra note 8, at 63; Dolzer and Stevens, supra note 16, at 104; Sacerdoti, supra note 8, at 387; and Kriebaum, supra note 35 , at 727.

${ }_{937}$ American Law Institute, supra note 51, at 200.

${ }^{938}$ Liberian Eastern Timber Corporation (Letco) $v$. The Government of the Republic of Liberia, ICSID case No. ARB/83/2, Award, 31 March 1986, (1987) 26 ILM 647, at 662.

${ }^{939}$ Ibid., 665 .
} 
There is no internationally agreed-upon definition of public purpose, policy or interest. What in fact constitutes it will rest, to a large extent, with the respective hoststate. $^{940}$ To question the existence of public purpose in a specific situation would entail evaluating the motivation of a sovereign state-policy. For this reason, international tribunals generally abstain from such an assessment. Otherwise, arbitral panels with even less structural independence and democratic legitimacy than domestic judges would be second-guessing decisions of the executive or the legislative, without the necessary protections and institutional credibility to review them. ${ }^{941}$ The European Court of Human Rights has supported this view. It has refrained from challenging the host-state's motives not only in its judgments on deprivations of property, like the James case, but also on those related with lesser interferences and controls of its use. $^{942}$ The Iran-US CT also granted an extensive discretion to the host state in Amoco and other of its judgments. ${ }^{943}$ Ad hoc and ICSID panels, until recently, have consistently followed this trend too. ${ }^{944}$

Public interest or utility is an old principle of international law. It was identified by Grotius as one of the two conditions for the exercise of the right of eminent domain. The other was the payment of compensation. ${ }^{945}$ Today, non-discrimination and due process complete the conditions of a lawful expropriation. There is no distinction between direct and indirect taking to this effect. Kriebaum sees a major departure from the traditional approach on the international law of expropriation in

\footnotetext{
${ }^{940}$ See American Law Institute, supra note 51, at 200.

${ }^{941}$ Been and Beauvais, supra note 583, at 105-6 \& 108. See, also, Sands, supra note 925, at xvii \& 122-3.

${ }^{942}$ See Chapter 3 supra.

${ }^{943}$ See Chapter 4 supra.

${ }^{944}$ See Chapter 5 supra.

${ }^{945}$ White, supra note 936 , at 145.
} 
the position of those that consider public purpose as an element of the existence of an indirect taking, rather than an element of its lawfulness. ${ }^{946}$ In her view:

If the approach of the Methanex and Saluka tribunals were to be followed, this would lead to a considerable gap in international investment protection: any non discriminatory measure, taken in the public interest that interferes with property rights will no longer be an expropriation regardless of its consequences. ${ }^{947}$

This conclusion is similar to that arrived at in Compañia de Aguas del Aconquija: "If public purpose automatically immunises the measure from being found to be expropriatory, then there would never be a compensable taking for a public purpose". ${ }^{948}$ The concept of indirect taking would loose its current meaning. ${ }^{949}$ Compensation is an essential part of the minimum standard of protection granted by international law to those investing abroad. In the law of expropriation, the deprivation of an alien's property must be compensated by the host-state, even if there is a legitimate general interest involved in the adoption of the expropriatory measure. As Schreuer points out:

the fact that a measure is in the public interest and non-discriminatory cannot be the answer to the question whether an expropriation has occurred. An expropriation may take place under perfectly legitimate circumstances. Arbitrariness, bad faith, lack of proportionality and other improprieties are not constitutive elements of expropriation. Their absence does not mean that an expropriation could not have taken place. ${ }^{950}$

Higgins supports this view. ${ }^{951}$ So does Dinstein, among others. ${ }^{952}$ Focusing on the effects of the measures adopted, in order to establish whether a regulation amounts to a taking, does not deprive the intent of the domestic authorities from

\footnotetext{
${ }^{946}$ Kriebaum, supra note 35 , at 726.

947 Ibid.

See Chapter 1 supra.

${ }^{948}$ Compañia de Aguas del Aconquija S.A. and Vivendi Universal S.A. (Vivendi II) case, supra note 744, para. 7.5.21.

${ }^{949}$ Kriebaum, supra note 35 , at 727.

${ }^{950}$ Schreuer, supra note 909 , at 110-1.

${ }^{951}$ Higgins, supra note 5, at 331.

952 Dinstein, supra note 8 , at 869.

See Chapter 1 supra.
} 
playing a role in this determination. However, this role is quite different from that attributed to it by the supporters of the police-powers doctrine. Reisman and Sloane explain that:

Even though a state's responsibility to pay compensation for expropriation does not, in any event, 'depend on proof that the expropriation was intentional', the manifestation of that intent at some level of the state's government generally furnishes a tribunal with a useful demarcation. ${ }^{953}$

Newcombe agrees with them. According to him, the intent will be relevant in the determination of whether a government measure is expropriatory or not, for a tribunal is more likely to find a taking where there is clear evidence of intent to expropriate. As he adds, "[t]hat intent is not a necessary element of expropriation simply means that a government cannot use lack of intent as a defence to a claim of expropriation". 954

The term police-powers is a source of significant confusion. ${ }^{955}$ In international law, the state has a right to regulate the society it governs. ${ }^{956}$ Nevertheless, the state can only interfere with property to the point of deprivation, without paying compensation, in exceptional circumstances. For instance, in those described under its criminal law. In certain cases of imminent and grave danger to the public health, the authorities might also adopt measures that deprive the owner of its property without paying compensation. Examples like these illustrate the meaning of police-powers from a sole-effect perspective. ${ }^{957}$

The main question regarding indirect takings is that of the moment in which a regulatory measure becomes compensable. The answer to it does not lie in the

\footnotetext{
${ }_{953}$ Reisman and Sloane, supra note 41, at 131-2.

${ }^{954}$ Newcombe, supra note 50 , at 25.

${ }^{955}$ See ibid., 26.

${ }^{956}$ See Beveridge, supra note 10, at 5-6.

${ }^{957}$ See Dolzer, supra note 60, at 80; and Fortier and Drymer, supra note 8, at 308 \& note 66 at 320.
} 
intention of the host-state that adopted the challenged measure. It lies in the degree of interference required to effectively and permanently deprive the foreign investor of his property. ${ }^{958}$ The problem of the degree has received different answers, depending on the forum in which they were given. The European Court of Human Rights considers the extinction of the rights of the owner as the chief criterion at the moment of determining whether a deprivation has occurred. ${ }^{959}$ The Iran-US CT required a non-ephemeral and unreasonable interference of the state in the rights of the alien. ${ }^{960}$ Some authors have seen a more flexible position in the judgments of the Iran-US CT than in those of the European Court. ${ }^{961}$ Both standards, nonetheless, involve at least a substantial and permanent interference; the same threshold usually required by ad hoc, ICSID and NAFTA arbitral panels in their awards. ${ }^{962}$

Related with the problem of degree is that of partial expropriations. ${ }^{963}$ Measures that affect an investment by merely reducing its value or profitability are normally not considered expropriatory in case-law and doctrine. At first sight, this approach would rule-out the possibility of partial takings. International judicial decisions, nevertheless, are divided on the issue. ${ }^{964}$ Kriebaum rightly argues that an answer to this question depends on the notion of substantial deprivation, which she describes in these words:

What it obviously does not mean is a total taking that leaves the investor without any residual rights. In a wider sense, almost all cases of indirect expropriation are only partial. Typically, there is no transfer of title and the physical property is not taken but the investor is deprived of the substance of the investment. The decisive point for an expropriation is the destruction of the capability to make use of the investment in

\footnotetext{
${ }^{958}$ See Waelde and Kolo, supra note 8 , at 825.

${ }^{959}$ See Chapter 3 supra.

${ }^{960}$ See Chapter 4 supra.

${ }^{961}$ Madalena, supra note 62, at 78; and Gutbrod and Hindelang, supra note 51, at 64-5.

${ }^{962}$ See Kriebaum, supra note 35 , at 723 .

See, also, Chapters 5 and 6 supra.

${ }^{963}$ See Herz, supra note 1, at 251.

${ }^{964}$ Kriebaum, supra note 661 , at $69, \& 73-82$.
} 
an economic sense. The investor need not be deprived of its physical property, but it has to be deprived of the economic benefit of its investment. ${ }^{965}$

The author concludes that a partial expropriation should be accepted if three requirements are fulfilled. First, the overall investment project must be able to be separated into a number of discrete rights. Second, the host-state must have deprived the foreign investor of a right which is covered by one of the items in the definition of investment in the applicable treaty. And third, this right must be capable of economic exploitation independently of the remainder of the investment. ${ }^{966}$

\subsection{Other compensable measures}

Whether the taking is total or partial, the host-state's obligation to pay an amount of money to a foreign investor may be based either on the law of expropriation or on the law of state responsibility. The former is known in doctrine as compensation; the latter as damages. In practice, both the requirement of a lawful taking and the obligation derived from an internationally wrongful act are normally referred to as compensation. ${ }^{967}$ Marboe argues that a lawful taking would require a prompt, adequate and effective compensation, while an unlawful taking would require full compensation. ${ }^{968}$ International case-law generally does not differentiate between the two types of expropriation at the moment of awarding an amount to the foreign investor on this basis. They will require the payment of compensation in conformity to the fair market value, i.e. the Hull formula, whether the expropriation was lawful or

\footnotetext{
${ }^{965}$ Kriebaum, supra note 35 , at 71.

See, also, Fortier and Drymer, supra note 8, at 308.

${ }^{966}$ See Kriebaum, supra note 35 , at 83.

${ }^{967}$ Marboe, supra note 27 , at 725-6.

See Chapter 1 supra.

${ }^{968}$ See Marboe, supra note 27, at 729-34.
} 
unlawful. ${ }^{969}$ But there is more to compensation than takings in international investment law. The expropriation clause is not the only treaty protection that will engage the international responsibility of the host-state if breached. Others include national and MFN treatment, the obligation of full protection and security, and nondiscrimination. And, most notably, FET.

The earliest FET clause is found in the 1948 Havana Charter. ${ }^{970}$ Article 11 (2) of this treaty provided that the ITO would be able to recommend and promote bilateral or multilateral agreements designed "to assure just and equitable treatment" for foreign investments. That same year, the Ninth International Conference of American States adopted the Economic Agreement of Bogotá. Its Article 22 provided for equitable treatment, but the treaty never entered into force. ${ }^{971}$ In the period that followed the failure of the Havana Charter and the Economic Agreement of Bogotá, the US dropped the term "just" from its FCNs, referring instead to equitable or FET in many of its treaties. ${ }^{972}$ The same standard appeared in the provisions of several other instruments too, like Article I of the 1959 Abs/Shawcross Draft; Article 1 (a) of the 1967 OECD Draft Convention; Paragraph 48 of the UN Draft Code of Conduct on TNCs; the guideline III (2) of the 1992 World Bank Guidelines; Articles 3 (1) and 2 (c) of the 1994 Colonia and Buenos Aires Investment Protocols of Mercosur, respectively; and Article 1.1 of the Draft MAI. Today, FET is included in Article 12

\footnotetext{
${ }^{969}$ See ibid., 731 \& 755-8.

${ }^{970}$ C Schreuer, 'Fair and Equitable Treatment in Arbitral Practice', (2005) 6/III JWIT 357, at 357.

${ }_{971}$ Available in Spanish at <http://www.oas.org/juridico/spanish/tratados/a-43.html> (last visited 31 March, 2008).

See C Yannaca-Small, 'Fair and Equitable Treatment Standard in International Investment Law', in OECD, Working Papers on International Investment (2004), Nr. 3, at 4.

See, also, <http://www.oas.org/juridico/english/Sigs/a-43.html> (last visited $31 \mathrm{March}, 2008$ ); and UNCTAD supra note 19, at 211.

${ }_{972} \mathrm{~S}$ Vasciannie, 'The Fair and Equitable Treatment Standard in International Investment Law and Practice', (1999) 70 BYIL 99, at 109-11; UNCTAD, supra note 19, at 211; and Yannaca-Small, supra note 971 , at 4 .
} 
(d) of the 1985 MIGA Convention; Article IV (2) of the 1987 ASEAN Agreement; Article 1105 (1) of the 1992 NAFTA; and Article 10 (1) of the 1994 ECT. It is also a common feature of BITs and FTAs, concluded and in force worldwide.

\subsubsection{Fair and equitable treatment}

The wording of the FET clause varies slightly from one treaty to another. Early BITs generally did not refer to FET. ${ }^{973}$ In the 1960 s, German and Swiss BITs included it in relation to the rules on the transfer of payments. FET started to appear in the following years of that decade as a general standard of treatment. ${ }^{974}$ Currently, the vast majority of these treaties include FET as one of its investment protections. ${ }^{975}$ An example of a typical FET clause, which resembles that of the Economic Agreement of Bogotá, is Article 3 (1) of the 1992 Argentina-Netherlands BIT:

Each Contracting Party shall ensure fair and equitable treatment to investments of investors of the other Contracting Party and shall not impair, by unreasonable or discriminatory measures, the operation, management, maintenance, use, enjoyment or disposal thereof by those investors. ${ }^{976}$

The FET in Article 1105 (1) of NAFTA is quite similar to the one included in most BITs. Under the heading of "minimum standard of treatment", this provision states that "[e]ach Party shall accord to investments of investors of another Party treatment in accordance with international law, including fair and equitable treatment and full protection and security".

\footnotetext{
${ }^{973}$ UNCTAD, supra note 19 , at $212 \& 217$.

${ }^{974}$ R Dolzer, 'Fair and Equitable Treatment: A Key Standard in Investment Treaties', (2005) 39 IL 87 , note 12 at 89 .

${ }_{975}$ Dolzer and Stevens, supra note 16 , at 58.

${ }^{976}$ Available at

$<$ http://www.unctad.org/sections/dite/iia/docs/bits/netherlands argentina.pdf $>$ (last visited 31

March, 2008).
} 
According to Dolzer, the purpose of FET is to fill those gaps that might be left by the other provisions of a treaty. FET would then be an independent standard of treatment referring to different types of governmental measures that deter foreign investment, which more specific standards are not suitable to address. As a consequence, FET will complement the investment protection offered by other clauses of the treaty. It will not replace them. In this sense, the FET clause would constitute a conventional application of the principle of equity praeter legem in international law. ${ }^{977}$ Like the takings provision, the FET clause establishes an absolute or non-contingent standard of treatment. ${ }^{978}$ It provides a fixed reference point for the alien and the authorities of the country were the investment was made. This means that the FET provision may be violated even if the foreign investor receives the same treatment as investors of the host-state or of other states.

Some BITs combine FET with the national and MFN treatments, i.e. with relative or contingent standards which depend upon those granted to other entities. ${ }^{979}$ Other BITs combine the FET standard with full protection and security. ${ }^{980}$ As with FET, it is difficult to give a precise meaning to full protection and security. In contrast with most investment protections, which impose restrictions on host-state activity, full protection and security seeks to impose certain positive duties on it. This

\footnotetext{
${ }^{977}$ Dolzer, supra note 974 , at $90-1$.

See, also, Higgins, supra note 72, at 219-20; M Janis, 'Equity in International Law', in R Bernhardt (ed), EPIL (1995), Vol. 2, at 109 \& 112; Brownlie, supra note 15, at 25; and UNCTAD, supra note 19, at 222-3 \& 226-7.

${ }^{978}$ Yannaca-Small, supra note 971, at 2; UNCTAD, supra note 19, at 214-5; and Schreuer, supra note 970 , at 367 .

${ }^{979}$ See, e.g., Art. 4 (1) of the 1997 Iran-South Africa BIT, available at $<$ http://www.unctad.org/sections/dite/iia/docs/bits/iran_southafrica.pdf> (last visited 31 March, 2008); and Art. 2 (1) of the 2001 Portugal-Turkey BIT, available at $<$ http://www.unctad.org/sections/dite/iia/docs/bits/turkey_portugal.pdf > (last visited 31 March, 2008). ${ }^{980}$ See, e.g., Art. 2 (2) of the 1983 Sweden-Yemen BIT, available at $<$ http://www.unctad.org/sections/dite/iia/docs/bits/sweden yemen.pdf> (last visited 31 March, 2008); and Art. 2 (2) of the 2002 Bosnia and Herzegovina-UK BIT, available at <http://www.unctad.org/sections/dite/iia/docs/bits/uk_bosnia.pdf> (last visited $31 \mathrm{March}, 2008$ ).
} 
standard originated in FCNs and has been held to involve an obligation of due diligence, requiring the governmental authorities to exercise reasonable care to protect foreign investments. ${ }^{981}$ Full protection and security is an absolute or noncontingent standard, and has been considered an obligation de moyens, thus not establishing a strict liability standard for the host-state. The alien would have to prove in court that the injury claimed is attributable to a lack of reasonable care in the conduct of the host-state, but without having to establish bad faith. ${ }^{982}$ This distinction is important, for if full protection and security were to be considered an obligation de résultat, the failure to comply with a specific result by the host-state would make it liable for damages, unless the governmental authorities could prove that this circumstance was attributable to a cause not imputable to them, i.e. a cas fortuit, fault of the claimant, or fault of a third party. ${ }^{983}$ While this standard has normally been applied in situations of physical protection of real and tangible property, the scope ascribed to FET by international tribunals has been broader. ${ }^{984}$

It has been sometimes questioned whether FET actually contains two standards -namely "fair" and "equitable", both with different meanings. No evidence of state practice supports this distinction, and the general assumption is that FET is a single, unified standard. ${ }^{985}$ International arbitral tribunals called upon to settle cases involving the FET standard have proved unwilling to give a specific definition of it. Instead, they have decided on a case-by-case basis, in accordance with the plain-

\footnotetext{
${ }^{981}$ See Dolzer and Stevens, supra note 16, at 60-1;

N Blackaby and L Paradell, 'Investment Treaty Arbitration', in J Tackaberry and A Marriott (eds.), Bernstein's Handbook of Arbitration and Dispute Resolution Practice (2003), Vol. I, at 723; and Redfern and Hunter, supra note 62, at 584.

${ }_{982}$ See Blackaby and Paradell, supra note 981 , at 723 , and Redfern and Hunter, supra note 62, at 584.

${ }^{983}$ See K Zweigert and H Kötz, Introduction to Comparative Law (1998), 501-2.

${ }^{984}$ Exceptionally, the range of full protection and security has also been extended to other circumstances.

See Redfern and Hunter, supra note 62, at 584-5.

${ }^{985}$ Dolzer, supra note 974 , at 91.
} 
meaning approach; whether the treatment provided by a particular host-state to a particular investor was both fair and equitable. ${ }^{986}$ The Oxford English Dictionary defines fair as according to rule. This is: equitable, impartial, just. ${ }^{987}$ In the same dictionary, equitable is related to acts characterized by fairness. This is: reasonable, just acts. Fair and equitable would, therefore, appear to be synonyms, and closely connected to the idea of justice. Nonetheless, the concept of fairness derives from the requirement of due process in US constitutional law, and it is not equated with justice there. In the US, fair refers to the procedure, while justice refers to the outcome of the trial. $^{988}$

The lack of a notion of fairness in some languages has obscured the already hazy meaning of the FET standard in international law. The following example illustrates this situation. The French version of certain BITs refer to un traitement juste et equitable, while the Spanish version mentions un tratamiento justo $y$ equitativo. ${ }^{989}$ These phrases have been normally translated as FET $^{990}$. Nevertheless, as Fletcher and Sheppard explain, Romance languages do not distinguish between "fairness" and "justice". The authors highlight the problems derived from this fact,

\footnotetext{
${ }^{986}$ Redfern and Hunter, supra note 62 , at 581.

${ }^{987}$ A vailable at <http://www.oed.com> (last visited 31 March, 2008).

${ }^{988}$ See Fletcher and Sheppard, supra note 628, at 60-3.

${ }^{989}$ See, e.g., Art. 2 of the 1996 France-Lebanon BIT, available in French at $<$ http://www.unctad.org/sections/dite/iia/docs/bits/france_lebanon_fr.pdf> (last visited 31 March, 2008);

and Art. 3 (1) of the 1999 Belgium and Luxembourg-Côte d'Ivoire BIT, available in French at $<$ http://www.unctad.org/sections/dite/iia/docs/bits/BLEU-Ivoire-fr.pdf> (last visited 31 March, 2008). See, also, e.g., Art. 4 (1) of the 1995 Chile-Paraguay BIT, available in Spanish at $<$ http://www.unctad.org/sections/dite/iia/docs/bits/chile_paraguay_sp.pdf> (last visited 31 March, 2008);

and Art. 3 (1) of the 2002 Guatemala-Spain BIT, available in Spanish at $<$ http://www.unctad.org/sections/dite/iia/docs/bits/spain_guatemala_sp.pdf> (last visited 31 March, 2008).

See, also, Art. 3 (1) of the Colonia Protocol; and Art. 2 (c) of the Buenos Aires Protocol of Mercosur, both cited at note 205 , supra.

${ }^{990}$ See, e.g., UNCTAD, supra note 19 , at 220.
} 
with the difficulties in translating Rawl's expression "justice as fairness". ${ }^{991}$ In French or Spanish it would stand as "justice as justice", and the meaning of this concept $-i . e$. that the principles of justice should be grounded in fair procedures of negotiationswould be lost. ${ }^{992}$ Fletcher and Sheppard argue that:

The particular attachment of Anglo-American legal culture to the concept of 'fairness' derives from the emphasis in the common law on procedural regularity as a value in itself, a value worth respecting apart from justice in the individual case. Our notions of fairness and fair play draw heavily on analogies from competitive sports and games, which pervade idiomatic English. Fair procedures are those in which both sides have an equal chance of winning. The playing field is level. Neither side hides the ball. No one draws from the bottom of the deck. Regardless of the sport or game, no one seeks an 'unfair' advantage -by 'hitting below the belt', 'stacking the deck', or 'loading the dice'. 993

This sports analogy can also be used in international law. FET would refer then to nothing less, and nothing more, than procedural propriety in the treatment given by the host-state to the foreign investor. Under the FET clause, the governmental authorities have an obligation de moyens, not an obligation de résultat. ${ }^{994}$ In other words, it is not the justice of the governmental treatment that would be guaranteed by FET, but its fairness. Though the distinction between these two concepts was made in the context of due process as a constitutional requirement in the US, it should be employed to interpret the undefined meaning of FET in investment treaties. After all, it was this country that introduced the term as it is currently found in treaty-law.

\footnotetext{
${ }^{991}$ See, in general, J Rawls, A Theory of Justice (2005).

${ }^{992}$ See Fletcher and Sheppard, supra note 628, at 62.

${ }^{993}$ Ibid., 63.

${ }^{994}$ See Zweigert and Kötz, supra note 983, at 501-2.
} 


\subsection{2. . Elements of procedural propriety}

Arbitral panels rarely find expropriations these days. They turn instead to FET, when available under the applicable treaty. ${ }^{995}$ No international case-law on FET existed before the year 2000. Since then, several judicial decisions have referred to this standard. The open-ended wording of these clauses has allowed international tribunals to identify different elements which form the obligation of procedural propriety. Their breach by the host-state, either individually or combined, will amount to a violation of the FET clause. ${ }^{996}$ Among the elements distinguished is due process, a basic requirement of the rule of law. Its violation constitutes the international wrongful act of denial of justice. ${ }^{997}$ MTD, Saluka and Compañia de Aguas del Aconquija refer to this duty, which may be breached by the judiciary, as well as by the executive. ${ }^{998}$ S.D. Myers, Loewen, and Thunderbird also mention it, in the context of NAFTA. ${ }^{999}$ The importance of due process as an element of FET has been recognised in the latest version of the US BIT. It expressly declares that FET "includes the obligation not to deny justice in criminal, civil, or administrative

\footnotetext{
${ }^{995}$ Kriebaum, supra note 35 , at 718 .

${ }^{996}$ See Dolzer, supra note 974 , at 87-8.
}

See, in general, Yannaca-Small, supra note 971, at 25-40; Schreuer, supra note 970, at 373-85; and S Schill, 'Fair and Equitable Treatment under Investment Treaties as an Embodiment of the Rule of Law', (2006) 6 International Law and Justice Working Papers 1, at 11-23.

${ }^{997}$ See Schreuer, supra note 970, at 381-2.

${ }_{998}$ See, e.g., MTD Equity Sdn. Bhd. and MTD Chile S.A. v. Republic of Chile, ICSID case No. ARB/01/7, Award, 25 May, 2004, para. 109, available at <http://ita.law.uvic.ca/documents/MTDAward_000.pdf> (last visited 31 March, 2008); Saluka Investments BV case, supra note 729, paras. 303 \& 307; and Compañia de Aguas del Aconquija S.A. and Vivendi Universal S.A.case, supra note 744, para. 7.4.11.

${ }^{999}$ See S.D. Myers, Inc. case, supra note 870, para. 134; Loewen Group, Inc. and Raymond L. Loewen v. United States of America, ICSID case No. ARB(AF)/98/3, Award, 26 June, 2003, para. 132, available at $<\mathrm{http}: / /$ ita.law.uvic.ca/documents/Loewen-Award-2.pdf $>$ (last visited $31 \mathrm{March}, 2008$ ); and International Thunderbird Gaming Corporation v. The United Mexican States, UNCITRAL arbitration, Award, 26 January, 2006, paras. 194, 197, \& 200, available at

$<$ http://ita.law.uvic.ca/documents/ThunderbirdAward.pdf> (last visited 31 March, 2008). 
adjudicatory proceedings in accordance with the principle of due process embodied in the principal legal systems of the world". ${ }^{100}$ This declaration has been also incorporated in FTAs recently concluded by the US. ${ }^{1001}$

The obligation of due process is closely connected to the concept of arbitrariness, as defined in the ELSI case, which ultimately followed the Neer claim: i.e. an act which shocks, or at least surprises, a sense of juridical propriety. ${ }^{1002}$ Many cases refer to arbitrariness in relation to the FET clause. For instance, Genin, TECMED, Eureko, Saluka, and PSEG ${ }^{1003}$, all BIT arbitrations. Some NAFTA tribunals, like those in S.D. Myers, Mondev, Loewen, Waste Management, and Thunderbird, have approached FET from this perspective too. ${ }^{1004}$ Due process is also related with the obligation of non-discrimination. BIT-based cases that refer to this element include Lauder, CMS, Eureko, and Saluka. ${ }^{1005}$ Among NAFTA arbitrations, Waste Management and Loewen mention it as well. ${ }^{1006}$ The obligation of due diligence is another vital part of the FET standard. Also called obligation of vigilance,

\footnotetext{
${ }^{1000}$ Art. 5 (2) of the 2004 Uruguay-US BIT, cited at note 51, supra.

${ }^{1001}$ See, e.g., Art. 10.5 (2)(a) of the 2004 CAFTA-DR, cited at note 855, supra.

${ }^{1002}$ Elettronica Sicula S.p.A. (ELSI) case, supra note 12, para. 128.
}

${ }^{1003}$ See Alex Genin, Eastern Credit Limited, Inc. and A.S. Baltoil v. Republic of Estonia, ICSID case No. ARB/99/2, Award, 25 June, 2001, paras. 367 \& 371, available at <http://ita.law.uvic.ca/documents/Genin-Award.pdf> (last visited 31 March, 2008); Técnicas Medioambientales TECMED S.A. case, supra note 707, para. 154; Eureko B.V. case, supra note 725 , para. 233; Saluka Investments BV case, supra note 729, para. 297; and PSEG Global Inc. and Konya Ilgin Elektrik Üretim ve Ticaret Limited Sirketi v. Republic of Turkey, ICSID Case No. ARB/02/5, Award, 19 January, 2007, para. 223, available at <http://ita.law.uvic.ca/documents/PSEGGlobalTurkey-Award.pdf> (last visited 31 March, 2008).

${ }^{1004}$ See S.D. Myers, Inc. case, supra note 870, para. 263; Mondev International Ltd. v. United States of America, ICSID case No. ARB(AF)/99/2, Award, 11 October, 2002, para. 127, available at $<$ http://ita.law.uvic.ca/documents/Mondev-Final.pdf> (last visited 31 March, 2008); Loewen Group, Inc. and Raymond L. Loewen case, supra note 999, para. 132; Waste Management, Inc. case, supra note 45, paras. 98 \& 115; and International Thunderbird Gaming Corporation case, supra note 999, paras. 194, 197, $199 \& 200$.

${ }^{1005}$ See Ronald S. Lauder case, supra note 680, para. 292-4; CMS Gas Transmission Company case, supra note 722, paras. 295; Eureko BV case, supra note 725 , para. 233; and Saluka Investments BV case, supra note 729 , paras. $303 \& 307$.

${ }^{1006}$ See Waste Management, Inc. case, supra note 45, para 98; and Loewen Group, Inc. and Raymond L. Loewen case, supra note 999 , para. 135. 
it has been mentioned as a part of FET in some cases that have interlocked it with the standard of full protection and security. ${ }^{1007}$

The focus on the FET debate has recently shifted to the respect for legitimate expectations. Several cases based on BITs mention this obligation: TECMED, Occidental, Eureko, PSEG, Siemens, and Enron. ${ }^{1008}$ Saluka even referred to it as the dominant element in FET. ${ }^{1009}$ A number of NAFTA disputes also mention the respect for legitimate expectations: Metalclad, ADF, Waste Management, GAMI, and Thunderbird. ${ }^{1010}$ The specific treatment expected by the foreign investor must be based on the host-state's legal framework, or on an undertaking made explicitly or implicitly by it. ${ }^{1011}$ The obligation to respect legitimate expectations generally adopts the form of a duty of consistent conduct by the authorities of the country in which the investment was made. ${ }^{1012}$ In practice, problems do not so much arise from changes in host-state legislation, but from inconsistent positions taken by organs of the

${ }^{1007}$ See, e.g., American Manufacturing \& Trading, Inc. (AMT) v. Republic of Zaire, ICSID case No. ARB/93/1, Award, 21 February, 1997, para. 6.05, available at <http://ita.law.uvic.ca/documents/AmericanManufacturing.pdf> (last visited 31 March, 2008); and Wena Hotels Ltd. case, supra note 677, paras. 84-95.

${ }^{1008}$ See Técnicas Medioambientales TECMED S.A. case, supra note 707, para. 154; Occidental Exploration and Production Co. (OEPC) case, supra note 721, para. 185; Eureko BV case, supra note 725, paras. 232 \& 235; PSEG Global Inc. and Konya Ilgin Elektrik Üretim ve Ticaret Limited Sirketi case, supra note 1003, paras. 223 \& 240-1; Siemens A.G. case, supra note 741, para. 299; and Enron Corporation Ponderosa Assets, L.P. v. Argentine Republic, ICSID case No. ARB/01/3, Award, 22 May, 2007, para. 262, available at <http://ita.law.uvic.ca/documents/Enron-Award.pdf $>$ (last visited 31 March, 2008).

${ }^{1009}$ See Saluka Investments BV case, supra note 729, paras. $302 \& 304$.

${ }^{1010}$ See Metalclad Corporation case, supra note 867, paras. 85 et seq.; ADF Group Inc. v. United States of America, ICSID case No. ARB(AF)/00/1, Award, 9 January, 2003, para. 189, available at <http://ita.law.uvic.ca/documents/ADF-award 000.pdf> (last visited 31 March, 2008); Waste Management, Inc. case, supra note 45, para. 98; GAMI Investments, Inc. case, supra note 878, paras. 100 et seq.; and International Thunderbird Gaming Corporation case, supra note 999, paras. 147-8 \& 196.

1011 Schreuer, supra note 970 , at 374.

See, e.g., CME Czech Republic B.V. case, supra note 681, para. 157; Saluka Investments BV case, supra note 729, para. 301-2; and Enron Corporation Ponderosa Assets, L.P. case, supra note 1008, para. 260.

${ }^{1012}$ See, e.g., Ronald S. Lauder case, supra note 680, paras. 295 et seq.; Técnicas Medioambientales TECMED S.A. case, supra note 707, para.154; MTD Equity Sdn. Bhd. and MTD Chile S.A. case, supra note 998, paras. 114, 163 \& 189; CMS Gas Transmission Company case, supra note 722, para. 279; Saluka Investments BV case, supra note 729, para. 307; and PSEG Global Inc. and Konya Ilgin Elektrik Üretim ve Ticaret Limited Sirketi case, supra note 1003, paras. 240, 248-9 \& 252. 
executive. For instance, the reversal of assurances by the host-state which led to legitimate expectations will violate the principle of FET. In any case, this is not an absolute obligation: it does not amount to a requirement for the host-state to freeze its legal system for the investor's benefit. A reasonable evolution of the former's law is part of what the investor must legitimately expect. ${ }^{1013}$ What FET requires is a stable and predictable legal and business framework for the foreign investor. ${ }^{1014}$

The obligation of transparency is related with the respect for legitimate expectations. It means that domestic authorities must make clear what they want from the investor, and cannot hide behind their own ambiguity or contradiction. ${ }^{1015}$ Maffezini, TECMED, MTD, Saluka, PSEG, and Siemens mention this element. ${ }^{1016}$ Metalclad, refers to it in the context of NAFTA. ${ }^{1017}$ Another element recognised in the FET standard is the obligation of good faith. This is a general principle of law that requires parties to a transaction to deal honestly and fairly with each other. ${ }^{1018}$

\footnotetext{
${ }^{1013}$ See, e.g., CMS Gas Transmission Company case, supra note 722, para. 277; Saluka Investments BV case, supra note 729, paras. 305-7; and Enron Corporation Ponderosa Assets, L.P. case, supra note 1008 , para. 261.

See, also, Schreuer, supra note 970, at 374-5; and Gutbrod and Hindelang, supra note 51, at 73-4.

1014 See, e.g., CMS Gas Transmission Company case, supra note 722, paras. 274 \& 276; Occidental Exploration and Production Co. (OEPC) case, supra note 721, paras. 183, 185, \& 192; Técnicas Medioambientales TECMED S.A. case, supra note 707, para. 154; Saluka Investments BV case, supra note 729, para. 303; and PSEG Global Inc. and Konya Ilgin Elektrik Üretim ve Ticaret Limited Sirketi case, supra note 1003 , paras. 253-4.

See, also, Metalclad Corporation case, supra note 867, para. 99.

${ }_{1015}$ T Waelde, 'Energy Charter Treaty-based Investment Arbitration. Controversial Issues', (2004) 5/III JWIT 373, at 387 .

${ }^{1016}$ See Emilio Agustin Maffezini case, supra note 599, para. 83; Técnicas Medioambientales TECMED S.A. case, supra note 707, para. 154; MTD Equity Sdn. Bhd and MTD Chile S.A. case, supra note 998, para. 109; Saluka Investments BV case, supra note 729, para. 307; PSEG Global Inc. and Konya Ilgin Elektrik Üretim ve Ticaret Limited Sirketi case, supra note 1003,, para. 223; and Siemens A.G. case, supra note 741 , para. 308.

${ }^{1017}$ See Metalclad Corporation case, supra note 867, paras. 76 \& 99.

See, also, Gutbrod and Hindelang, supra note 51, note 68 at 72.

${ }^{1018}$ A D'Amato, 'Good Faith', in R Bernhardt (ed.), EPIL (1995), Vol. II, at 599.
} 
TECMED, Saluka, PSEG, and Siemens refer to it ${ }^{1019}$; as well as S.D. Myers, and Waste Management. ${ }^{1020}$

In all, FET is an abstract legal term whose content is normally determined by international law in its application to the facts presented by the parties to an investment dispute. ${ }^{1021}$ The nature of FET is broad. Compliance with this clause can also depend, for example, on the breach or the lack of breach of a domestic provision, as Noble Ventures recognise, along with GAMI. ${ }^{1022}$ Arbitral practice shows that this standard can be violated even if no mala fides is involved. ${ }^{1023}$

\subsection{The international minimum standard}

One of the most debated issues regarding FET has been that of its relation with the customary standard of minimum treatment. According to Mann, Dolzer, Stevens, Vasciannie, and Schreuer, it must be presumed that if the parties to a treaty wanted to

1019 See Técnicas Medioambientales TECMED S.A. case, supra note 707, para. 153; Saluka Investments BV case, supra note 729, para. 303; PSEG Global Inc. and Konya Ilgin Elektrik Üretim ve Ticaret Limited Sirketi case, supra note 1003, para. 223; and Siemens A.G. case, supra note 741, para. 308.

${ }^{1020}$ S. D. Myers, Inc. case, supra note 870, para. 134; and Waste Management, Inc. case, supra note 45, para. 138.

${ }^{1021}$ Dolzer, supra note 974 , at 88 .

See, also, Muchlinski, supra note 748 , at 625.

${ }^{1022}$ See Noble Ventures, Inc. v. Romania, ICSID case No. ARB/01/11, Award, 12 October, 2005, para. 178, available at <http://ita.law.uvic.ca/documents/Noble.pdf> (last visited $31 \mathrm{March}, 2008$ ); and GAMI Investments, Inc. case, supra note 878, para. 91.

See, also, Schill, supra note 996, at 13-5.

An exception to this trend can be found in $A D F$, where the tribunal considered that "something more than simple illegality or lack of authority under the domestic law of a State is necessary to render an act or measure inconsistent with the customary international requirements of Article 1105(1)".

ADF Group Inc. case, supra note 1010, para. 190.

See Dolzer, supra note 974, at 88; and Yannaca-Small, supra note 971, at 35.

${ }^{1023}$ Schreuer, supra note 970 , at 384.

See, e.g., Occidental Exploration and Production Co. (OEPC) case, supra note 721, para. 185; CMS Gas Transmission Company case, supra note 722, para. 280; Siemens A.G. case, supra note 741, para. 299; Enron Corporation Ponderosa Assets, L.P. case, supra note 1008, para. 263; and Compañía de Aguas del Aconquija S.A. and Vivendi Universal S.A. (Vivendi II) case, supra note 744, para. 7.4.12. See, also, Mondev International Ltd. case, supra note 1004, para. 116; and Loewen Group, Inc. and Raymond L. Loewen case, supra note 999, para. 132. 
refer to customary international law, they would have referred to it as such, rather than using a different expression. ${ }^{1024}$ Dolzer rightly points out that it is doubtful that the international minimum standard, first described in the Neer case in relation to the physical security of an alien before 1945 , should govern the contemporary regime of international investment law. ${ }^{1025}$ In the absence of a clear indication to the contrary Schreuer adds-, the FET standard contained in BITs should be considered an autonomous concept, whose meaning will ultimately depend on the specific wording of the clause establishing it. ${ }^{1026}$ International case-law tends to support this doctrinal approach. Tribunals have not restricted the application of the FET clause to the lack of due diligence, wilful neglect, clear unreasonableness, or bad faith, already covered by the customary standard. ${ }^{1027}$

The most intensive discussion on the relationship between the two standards has taken place in the context of Art. 1105 (1) of NAFTA. ${ }^{1028}$ Early arbitral decisions, notably S.D. Myers and Pope \& Talbot, did not regard the FET standard in this provision as restricted to customary international law. ${ }^{1029}$ The tribunal's reasoning on the issue was detailed in Pope \& Talbot, and one of the arguments given was particularly persuasive. Namely, that:

the contrary view [...] would provide to NAFTA investors a more limited right to object to laws, regulation and administration than accorded to host country investors and investments as well as to those from countries that have concluded BITs with a NAFTA party. This state of affairs would surely run afoul of Articles 1002 and 1003,

\footnotetext{
${ }^{1024}$ Schreuer, supra note 970 , at 360 .

${ }^{1025}$ See Dolzer, supra note 974 , at 93.

${ }^{1026}$ Schreuer, supra note 970, at 364.

${ }^{1027}$ Blackaby and Paradell, supra note 981 , at 722 .

See, also, Redfern and Hunter, supra note 62, at 583-4.

${ }^{1028}$ See Schreuer, supra note 970 , at 362-4.

${ }^{1029}$ See S.D. Myers, Inc. case, supra note 870, para. 264; and Pope and Talbot. Inc. v. The Government of Canada, NAFTA, UNCITRAL arbitration, Award, 10 April, 2001, paras. 110-8, available at <http://ita.law.uvic.ca/documents/Award_Merits2001_04_10_Pope_001.pdf> (last visited 31 March, 2008).
} 
which give every NAFTA investor and investment the right to national and most favoured nation treatment ${ }^{1030}$

The NAFTA Free Trade Commission (FTC), a body composed of representatives of the three parties to this treaty with the power to adopt binding statements on it, issued a Note of Interpretation in 2001 on the question. In it, the FTC declared that Art. 1105 (1) "prescribes the customary international law [...] standard of treatment of aliens as the minimum [...] to be afforded to investments of investors of another Party". ${ }^{1031}$ The Note of Interpretation further stated that FET does "not require treatment in addition or beyond that which is required by the customary international $[\ldots]$ minimum standard". Subsequent decisions of NAFTA tribunals have accepted the FTC interpretation without resistance. ${ }^{1032}$

\subsubsection{Developments in treaty-law}

The FTC's interpretation embodied the concern of NAFTA members on the expansion of the traditional minimum standard recognised in international law. Recent US FTAs and BITs, as well as latest BIT models of Canada and Mexico, expressly follow this approach. ${ }^{1033}$ NAFTA awards, issued after this interpretation,

\footnotetext{
${ }^{1030}$ Pope \& Talbot Inc. case, supra note 1029, para. 117.

${ }^{1031}$ Available at <http://www.international.gc.ca/trade-agreements-accords-commerciaux/disp$\mathrm{diff} /$ nafta-interpr.aspx?lang=en $>$ (last visited 31 March, 2008).

${ }^{1032}$ Schreuer, supra note 970 , at 363.
}

See, e.g., Mondev International Ltd. case, supra note 1004, paras. 111-3 \& 118-25; United Parcel of America Inc. (UPS) v Government of Canada, Award on Jurisdiction, 21 November, 2002, para. 97, available at <http://ita.law.uvic.ca/documents/UPS-Jurisdiction.pdf> (last visited 31 March, 2008); ADF Group Inc. case, supra note 1010, paras. 176-9 \& 186; Loewen Group, Inc. and Raymond L. Loewen case, supra note 999, paras. 125-6 \& 128; and International Thunderbird Gaming Corporation, supra note 999, paras. 192-3.

${ }^{1033}$ See, e.g., Art. 15.5 para. 2 of the 2003 Singapore-US FTA, cited at note 854 , supra; Art. 5 para. 2 of the 2004 Uruguay-US BIT, cited at note 51, supra; and Art. 10.5 para. 2 of the 2006 Oman-US FTA, cited at note 856 , supra. 
have struggled to comply with the views of the FTC, while acknowledging at the same time the dynamic nature of the international standard. The tribunal in Mondev, for instance, refused to accept that the meaning of Article 1105 was limited to the Neer claim's formula. ${ }^{1034}$ In its wording:

Neer and like arbitral awards were decided in the 1920s, when the status of the individual in international law, and the international protection of foreign investments, were far less developed than they have since come to be. In particular, both the substantive and procedural rights of the individual in international law have undergone considerable development. In the light of these developments it is unconvincing to confine the meaning of 'fair and equitable treatment' and 'full protection and security' of foreign investments to what those terms - had they been current at the time - might have meant in the 1920s when applied to the physical security of an alien. To the modern eye, what is unfair or inequitable need not equate with the outrageous or the egregious. In particular, a State may treat foreign investment unfairly and inequitably without necessarily acting in bad faith. ${ }^{1035}$

According to this panel, the customary standard of minimum treatment has been

modified by state practice:

Investment treaties run between North and South, and East and West, and between States in these spheres inter se. On a remarkably widespread basis, States have repeatedly obliged themselves to accord foreign investment [a FET, and full protection and security]. In the Tribunal's view, such a body of concordant practice will necessarily have influenced the content of rules governing the treatment of foreign investment in current international law. It would be surprising if this practice and the vast number of provisions it reflects were to be interpreted as meaning no more than the Neer Tribunal (in a very different context) meant in 1927 [sic]. ${ }^{1036}$

The evolutionary potential of Article 1105 was recognised again in $A D F$, where the panel profusely quoted Mondev on the issue. ${ }^{1037}$ A year later, Waste Management

See, also, Art. 5 para. 2 of the 2006 Canada-Peru BIT, cited at note 1, supra; and International Institute for Sustainable Development, Investment Treaty News, 16 May, 2006, available at: $<$ http://www.iisd.org/pdf/2006/itn_may16_2006.pdf> (last visited $31 \mathrm{March}, 2008$ ); referring to the 2006 Mexico-UK BIT.

${ }_{1034}$ Mondev International Ltd. case, supra note 1004, para. 114.

${ }^{1035}$ Ibid., para. 115 .

${ }^{1036} \mathrm{Ibid}$., para. 117

See, also, ibid., paras. $119 \& 123$.

${ }^{1037}$ See ADF Group Inc. case, supra note 1010, paras. 179, $180 \& 183-4$. 
summarised both Mondev and $A D F .{ }^{1038}$ Thunderbird conformed to these decisions, but in its own terms. ${ }^{1039}$

In general, BIT arbitrations have not followed the FTC's interpretation. ${ }^{1040}$ As Schreuer explains, tribunals outside the NAFTA context have construed the relevant provisions in BITs on the basis of their respective wording. ${ }^{1041}$ Notwithstanding the legal gymnastics to which NAFTA awards have undergone to integrate a customarybound notion of FET and a modern interpretation of Article 1105, the solution given by the FTC should not be applied beyond the scope of this treaty. FET is a conventional standard: one that incorporates the minimum standard developed in customary international law, and complements it. At present, the minimum treatment guaranteed in BITs and EIAs comprise not only FET, but also the protection against expropriation, as well as the principles of national and MFN treatment, full protection and security, and non-discrimination. This protective framework was designed by the US and Western European countries. Most countries in Africa, Asia, Eastern Europe, Latin American, and Oceania adhere to it today. Foreign investors and their counsel are well aware of these treaty-protections, and they are not shy at the moment of referring to them when lodging a claim under a BIT or a EIA. The following observation of the arbitral panel in PSEG illustrates a common situation these days:

\footnotetext{
${ }^{1038}$ Waste Management, Inc. case, supra note 45, paras. 91-3.

See, also, GAMI Investments, Inc. case, supra note 878, para. 95.

${ }_{1039}$ International Thunderbird Gaming Corporation, supra note 999, para. 194.

${ }^{1040}$ See, e.g., MTD Equity Sdn. Bhd. and MTD Chile S.A. case, supra note 998, paras. 110-2; CMS Gas Transmission Company case, supra note 722, paras. 282-4; Occidental Exploration and Production Co. (OEPC) case, supra note 721, para. 192; Saluka Investments BV case, supra note 729, paras. 2945; Siemens A.G. case, supra note 741, paras. 291-9; and Enron Corporation Ponderosa Assets, L.P. case, supra note 1008, paras. 256-8.

Compañia de Aguas del Aconquija did endorse the evolutionary principle of the minimum standard of treatment, as expressed in Mondev and $A D F$.

Compañia de Aguas del Aconquija S.A. and Vivendi Universal S.A. (Vivendi II), supra note 744, note 325 at para. 7.4.7.

${ }^{1041}$ Schreuer, supra note 970 , at 364.
} 
As it is by now customary in investment arbitration, the aggrieved party invokes the breach of every BIT clause dealing with the standards of the investor's protection, while the Respondent vehemently denies any breach. ${ }^{1042}$

From these protections, that against takings is one of the two most relied-upon by claimants in investor-to-state disputes. The other is FET. ${ }^{1043}$

In the case-law of the Iran-US CT, every time the judges wanted to award compensation for measures that did not amount to a taking, the tribunal applied the concept of other measures affecting property rights. FET has sometimes been seen as an equivalent notion. ${ }^{1044}$ In several arbitrations where no expropriation was found, the tribunal concluded that the FET clause was breached. These cases include Maffezini, MTD, Occidental, Saluka, PSEG, and Enron ${ }^{1045}$, among BIT arbitrations; S.D. Myers, and Pope \& Talbot, among NAFTA disputes. ${ }^{1046}$ At first sight, it would appear that an interference that amounts to a substantive deprivation of the alien's property will constitute an indirect taking, while a lesser interference will amount to a breach of the FET clause. However, an indirect expropriation can overlap with an unfair and inequitable treatment. In a number of arbitrations where a taking was found, the tribunal concluded that the FET clause was also breached by the host-state. CME, Middle East Cement, TECMED, ADC and Siemens are examples of such a

1042 PSEG Global Inc. and Konya Ilgin Elektrik Üretim ve Ticaret Limited Sirketi case, supra note 1003 , para. 220.

${ }^{1043}$ Dolzer, supra note 974 , at 87.

See, also, Schreuer, supra note 970, at 357; and M Kantor, 'Fair and Equitable Treatment: Echoes of FDR's Court-Packing Plan in the International Law Approach Towards Regulatory Expropriation', (2006) 5 LPICT 231, at 238.

${ }_{1044}^{10}$ See, e.g., Heiskanen (2007), supra note 60, at 218-9.

${ }^{1045}$ See Emilio Agustin Maffezini case, supra note 599; MTD Equity Sdn. Bhd. and MTD Chile S.A. case, supra note 998; Occidental Exploration and Production Co. (OEPC) case, supra note 721; Saluka Investments BV case, supra note 729; PSEG Global Inc. and Konya Ilgin Elektrik Üretim ve Ticaret Limited Sirketi case, supra note 1003; and Enron Corporation Ponderosa Assets, L.P. case, supra note 1008.

${ }^{1046}$ See S.D. Myers, Inc. case, supra note 870; and Pope and Talbot. Inc. case, supra note 1029. 
situation ${ }^{1047}$. Metalclad too. ${ }^{1048}$ These cases show that FET and the protection against indirect expropriation are related but distinct standards. They do share some of their constitutive elements. Nevertheless, their legal nature is different. While the FET clause establishes an obligation de moyens, the protection against expropriation combines the latter with an obligation de résultat -the payment of compensation.

One of these shared elements is due process. It is a requirement of a lawful expropriation, and a constituent part of the notion of FET. Another of these elements is the respect for prior commitments and the legitimate expectations of the foreign investor. This obligation is not only a part of procedural propriety, but also of the concept of indirect takings, as traditionally understood in international law. Far from being opposed to the sole-effect rule, the respect for legitimate expectations complements such an approach. The threshold question is answered by the application of the substantive-deprivation test. Other elements might help in the determination of the expropriatory nature of the respective measure. The frustration of the foreign investor's reliance on representations or undertakings, made explicitly or implicitly by the host-state, is another. ${ }^{1049}$ These commitments can have a legal nature, either national or international, or a non-legal nature. ${ }^{1050}$ Representations and undertakings can be found in a treaty, a law, a license or a permit, or even in an investment brochure. ${ }^{1051}$ To be legitimate, the expectation must be reasonable. Expecting the host-state not to subject its legal system to any alterations with regards

\footnotetext{
${ }^{1047}$ See CME Czech Republic B.V. case, supra note 681; Middle East Cement Shipping and Handling Co. case, supra note 685; Técnicas Medioambientales TECMED S.A. case, supra note 707; ADC Affiliate Limited and ADC \& ADMC Management Limited case, supra note 739; and Siemens A.G. case, supra note 741.

${ }^{1048}$ See Metalclad Corporation case, supra note 867.

1049 See Paulsson and Douglas, supra note 8, at 158; and Kunoy, supra note 51, at 478-82.

${ }^{1050}$ See Waelde and Kolo, supra note 8, at 843-5; Kunoy, supra note 51, at 482; and Newcombe, supra note 50 , at 45 .

${ }^{1051}$ Madalena, supra note 62, at 77; and Gutbrod and Hindelang, supra note 51, note 33 at 65-6.
} 
to the foreign investors, for instance, would not be reasonable. ${ }^{1052}$ Fortier and Drymer point out that the allowed level of interference with the foreign investor's legitimate expectations is a matter of degree. Furthermore, it is largely a question of consistency and, ultimately, fairness in the behaviour of the host-state towards the alien. ${ }^{1053}$ It is not strange, then, that this concept reappears as one of the elements of the FET standard. Hence, as a separate cause of action for claiming damages.

\subsubsection{The protection of foreign investors}

Dolzer asks the supporters of the sole-effect doctrine to explain why the treatment of aliens in international law should require a higher standard of protection than that established by the major domestic legal orders. ${ }^{1054}$ The relevance of this question is not limited to the problem of indirect expropriation, for in its answer lies the raison d'être of international investment law as a whole. Sornarajah contends that the dominance of this regime, originally designed by the US to protect its investors abroad, can only be explained in terms of power, and not in terms of logic or reasoning:

The positivist notions of sovereignty which were the dominant notion in public international law during this period should have supported the claims of the Latin American states for the regime they argued [was] more consistent with state sovereignty than the intrusive regime which the [US government] argued for on the basis of values which were not universal but were constructed to achieve investment protection. $^{1055}$

\footnotetext{
${ }^{1052}$ See, Kunoy, supra note 51, at 479; and Gutbrod and Hindelang, supra note 51, at 73-4

${ }^{1053}$ Fortier and Drymer, supra note 8 , at 306.

${ }^{1054}$ Dolzer, supra note 60 , at 91 .

See, also, Gutbrod and Hindelang, supra note 51, note 23 at 64.

${ }^{1055}$ Sornarajah, supra note 3 , at 55.
} 
Sornarajah is right on the role played by power in the establishment of the international minimum standard. His assessment of sovereignty and the protection of aliens, however, is wrong. Independence and sovereignty are synonyms in international law. ${ }^{1056}$ As a sovereign, the state is not subject within its territory to the jurisdiction of any state other than itself, or bound by any law other than its own and international law. ${ }^{1057}$ Sornarajah forgets this last part of the concept of independence, i.e. that the sovereign state can choose to bind itself to international law, whether customary or conventional, thus limiting its own sovereignty. The consent of the state to a customary norm may be express or implied. It requires state practice and opinion juris -or, in the words of Article 38 (1) (b) of the ICJ's Statute: a general practice accepted as law. The consent of the state may even be presumed in case of acquiescence; that is to say, the silence or passivity of the state towards the conduct of other states that would otherwise deserve a protest. The consent in treaties will generally be explicit. ${ }^{1058}$ Once given, the state will have to keep its agreement under the principle of pacta sunt servanda. This principle that does not only apply to treaties, but to any instrument concluded by the state in any form. ${ }^{1059}$ But there is more to sovereignty and the protection of aliens. It can be fairly claimed that the international minimum standard is the forerunner of the international system of human rights that governs the treatment of nationals and foreigners alike. Currently, an international minimum standard is enshrined in BITs and EIAs, as well as in the

\footnotetext{
${ }^{1056}$ Malanczuk, supra note 72 , at 17-8.

On the relation between territorial sovereignty and international law, see Dunn, supra note 1, at 171-2.

${ }^{1057}$ See H Steinberger, 'Sovereignty', in R Berhardt (ed.), EPIL (2000), Vol. IV, at 511-2.

${ }^{1058}$ In relation to treaties establishing rights for third states, Art. 36 of the 1969 Vienna Convention on the Law of Treaties provides that the consent of the third state is presumed "so long as the contrary is not indicated" and "unless the treaty otherwise provides".

Available at <http://untreaty.un.org/ilc/texts/instruments/english/conventions/1_1_1969.pdf> (last visited 31 March, 2008).

In force since 1980.

${ }^{1059}$ See, in general, Lachs, supra note 1046.
} 
UN Covenants, the European Convention, the American Convention, and the African

Charter on human rights. ${ }^{1060}$ Arguing that the norms on the treatment of aliens go against the state's sovereignty is equivalent to arguing that the norms on human rights go against it.

Sornarajah has dubbed the international law on foreign investment as a law of greed. ${ }^{1061}$ His answer to Dolzer's question can only be formulated in negative terms:

there is no reason why a foreigner investor who voluntarily assumes a risk by entering a host state should be insulated from the risks inherent in the host state and should not bear the costs of his own adventure. ${ }^{1062}$

$\mathrm{He}$ is wrong again. There are several reasons for protecting aliens. Relying on the law of the host-state alone has never been an attractive option for foreign investors. Salacuse points out some of the risks to which an alien is subject abroad. It is not only that domestic law can be easily changed after the investment has been made by the host-state, or that the government officials of the latter -responsible for applying this law- may act impartially towards him. It is also that, in the past, hoststates have treated foreign investors in an arbitrary and discriminatory manner in the past, imposing onerous conditions on the operation of foreign investment. ${ }^{1063}$

The US-Mexican General Claims Commission had already observed in the 1926 Hopkins case that:

The citizens of a nation may enjoy many rights which are withheld from aliens, and, conversely, under international law aliens may enjoy rights and remedies which the nation does not accord to its own citizens. ${ }^{1064}$

\footnotetext{
${ }^{1060}$ See Paulsson, supra note 82 , at 35.

${ }^{1061}$ A Newcombe, 'Sustainable Development and Investment Treaty Law', (2007) 3/VIII JWIT 357, at 359.

1062 Sornarajah, supra note 68 , at 55.

1063 Salacuse, supra note 634 , at 659.

See, also, Been and Beauvais, supra note 583, at 107 \& 118; and Newcombe, supra note 50, at 46-7.

1064 George W. Hopkins (US v. Mexico), US-Mexican General Claims Commission, Opinion and decision, 31 March, 1926, (1926) 21 AJIL 160, para. 16.

This case was quoted in S.D. Myers, Inc. case, supra note 870, para. 260.
} 
Dunn developed this idea two years later:

From a practical point of view, the foreigner, although he may be accorded full civil rights on the same basis as citizens, is often at a disadvantage in any dispute which he may have with the agents of the state of his sojourn merely by reason of the fact that he is a foreigner. Furthermore, being deprived of political rights outside of his own country, he is not at liberty to participate in the determination of the social and economic order and has not the political means for the protection of his interests that are at the disposal of the citizen. Perhaps for these reasons as much as any other, it has been found necessary, in a world of diverse cultures and heterogeneous peoples, of strong governments and weak governments, of orderly countries and disorderly countries, to work out a common code of treatment of aliens in order that there might be some basis of security and predictability upon which to build the present complex structure of international intercourse.

This common code of treatment is technically called the 'minimum standard of justice ${ }^{, 1065}$

Aliens constitute a minority that requires special protection. Ignatieff illustrates

this fact by reference to the problem of balancing liberty and security in the fight

against of terrorism. He says:

Democratic citizens do not actually have to balance their [sic] liberty against their security, but their security against the liberty of others, usually non-citizens. Decisions to abridge civil liberties for non-nationals have aroused little public resistance since September 11 , while measures aimed at citizens, like national identity cards or more intrusive security screenings at airports, have been stymied. ${ }^{1066}$

Ignatieff concludes that "[o]bserving international law is the best way to correct the partiality that states feel towards their own citizens and mitigate the discrimination that it meets out towards non-citizens". ${ }^{1067}$ The same conclusion is applicable regarding the balance of interests between the community and the individual involved in the problem of indirect expropriation. In the James case, the European Court of Human Rights recognised aliens as a minority that should receive special protection. ${ }^{1068}$ So did the arbitral panel in TECMED. ${ }^{1069}$ The special

\footnotetext{
${ }^{1065}$ Dunn, supra note 1, at 174.

See, also, E Root, 'The Basis of Protection to Citizens Residing Abroad', (1910) 4 AJIL 517, at 521-2.

${ }^{1066} \mathrm{M}$ Ignatieff, The Lesser Evil. Political Ethics in an Age of Terror (2005), xvi.

1067 Ibid.

1068 James and others case, supra note 295, para. 63.

See, also, Lithgow and others case, supra note 304, paras. 111-9.

${ }^{1069}$ Técnicas Medioambientales TECMED S.A. case, supra note 707, para. 122.
} 
protection expected by foreign investors comprises the payment of compensation in case of a taking, and of damages in case of any breach of the applicable investment treaty. It also includes the possibility to settle any investment dispute before an international tribunal. On this respect, Paulsson remarks:

The great difficulty is to understand that international adjudication is not foreign [sic] adjudication. The citizens of a given country have no stake in foreign justice; they did not create it, and whatever they may think of its qualities in the abstract it has no legitimate basis on which to judge them (unless they venture abroad). Therefore, as long as international justice is thought of as foreign justice, it will be resisted. The key is the perception of inclusiveness; when 'we' are part of the processes of international law, consulted in its formation and benefiting from its protections and remedies, it becomes 'our' law too. ${ }^{1070}$

The protection of aliens is, nonetheless, not unlimited. It does not cover them from any risk faced while investing abroad. Ordinary commercial risks are excluded. ${ }^{1071}$ The tribunal in Maffezini, for example, emphasized that BITs are not insurance policies against bad business judgments. ${ }^{1072}$ This approach goes back to Oscar Chinn, and can also be found in the case-law of the Iran-US CT. ${ }^{1073}$

\subsection{Conclusion}

Judges and arbitrators have generally followed a sole-effect rule on the problem of indirect takings. Its counterpart, the police powers solution, has been a mere exception to an established trend in international case-law. NAFTA arbitrations have prompted a change in this state of affairs. The protections designed to promote

\footnotetext{
${ }^{1070}$ Paulsson, supra note 82 at 27.

${ }^{1071}$ See, e.g., Kunoy, supra note 51, at 477-8; Gutbrod and Hindelang, supra note 51, at 63; or Kunoy, supra note 916 , at 342 .

${ }^{1072}$ Emilio Agustin Maffezini case, supra note 599, para. 64.

See, also, Middle East Cement Shipping and Handling Co. case, supra note 685, para. 153.

${ }^{1073}$ See Oscar Chinn case, supra note 425, at 88.

See, also, Starrett Housing Corporation, Starrett Systems, Inc., Starrett Housing International, Inc. case, supra note 426, at 149.
} 
the investment of nationals of developed states in developing countries are now being used to challenge the regulatory measures adopted by any governmental authority, whether of a developing or of a developed state. Against this background, the US has decided to substitute its long-standing advocacy of the international minimum standard for that of the national treatment it so strongly opposed in the past. Abandoning the international standard means abandoning the sole-effect rule, and the best way to achieve this is by transforming treaty-law, as a guideline for decisionmakers in order to, ultimately, transform customary international law. Canada and other Western European countries are starting to see the convenience of the US approach.

While the police-powers rule derives from the US regulatory takings doctrine, the sole-effect variant is strongly grounded in international law. It is true: African, Asian, and Latin American countries did come to accept the sole-effect approach because they had no other choice. This rule was part of the international minimum standard required by capital-importing states as a condition to invest the funds or materials developing states need to build or rebuild their economies. And it is also true that the sole-effect approach may not be completely consistent in international case-law, not even within the reasoning of a particular tribunal in a specific award. But it is a position that has provided a useful guidance to foreign investors and hoststates, as well as to judges and arbitrators. Furthermore, it is a solution that finds support in the traditional concepts of sovereignty and lawful expropriation, and ultimaltely in the minimum standard of treatment in which international investment law is based. 
The challenge to the regulatory powers of the host-state is, nevertheless, not restricted to the question of indirect expropriation. In the exercise of its authority, a government may breach different provisions of a BIT or an EIA. These are designed to reflect the various aspects of the international minimum standard protected by treaty-law. The violation of any investment protection by the host-state will trigger its international responsibility. Against the uncertainty provoked by the current soleeffect/police-powers debate, claimants in investment disputes have opted to allege the breach of the FET clause in virtually every proceeding brought before an arbitral panel established under a BIT or an EIA. The undefined concepts of indirect takings and FET have led to some confusion on the relation between the two clauses. The answer to the threshold question in each case lies on two independent but complementary concepts -substantial deprivation, for indirect takings, and procedural propriety, for FET. 


\section{CONCLUSION}

The protection of property is currently part of not one, but two areas of international law. Both human rights and investment treaties provide for a minimum standard of treatment. There are, nonetheless, some differences which go beyond the fact that under international human rights law the minimum standard is applicable to aliens and nationals of the host-state alike. The most developed human rights caselaw on the subject comes from Europe. It has neither adopted the sole-effect nor the police-powers rules as a solution to the threshold question. The reason for this approach lies in a distinction which is not available under BITs and EIAs. Controls on the use of property and lesser interferences give the decision-maker in Europe the option of achieving a similar result to that aimed at by supporters of the policepowers doctrine -i.e. no compensation for justified measures. The fair balance test on which this conclusion must be based is, however, significantly more complete than the purpose test applied to the police-powers rule. In case of deprivation, the affected individual or legal entity does have a right to be compensated under European human rights law. Nevertheless, the host-state is not constrained by a Hull formula applicable to all events. It is, furthermore, given a wide margin of appreciation regarding compensation for nationalisations. No need for a police-powers solution here, either.

Investment-dispute panels only exceptionally refer to international human rights law. The treaty protections over which they have jurisdiction are closer to that 
of the Iran-US CT, so arbitrators in these controversies tend to follow and develop its case-law on the protection of property. The Iran-US CT considered compensation for expropriation as part of the minimum standard of treatment. It answered the threshold question on a case-by-case basis, applying a sole-effect rule. An interference amounted to an expropriation when it was non-ephemeral and unreasonable, irreversibly depriving the owner of the effective use and control of his property. The Iran-US CT distinguished lawful from unlawful takings concerning restitution, but not with regards to the applicable standard of compensation. In its decisions, any expropriation required the payment of a full compensation. This standard was not extended to other measures affecting property rights. The tribunal relied on the concept of lesser interferences, as developed in European human rights law, to construe this phrase of the Claims Settlement Declaration. Such an interpretation offered the Iran-US CT an alternative to the sole-effect rule and the full compensation standard in those cases were an interference not amounting to an indirect taking was found. Claimants affected by these measures were awarded partial compensations.

BITs and EIAs expressly recognise today the host-state's right to expropriate foreign property. Nonetheless, it is a right that must be exercised in conformity with certain requirements. One of these conditions is the adoption of the respective measure for a public purpose; another is the payment of prompt, adequate and effective compensation. As in the case-law of the European Commission and Court of Human Rights, and the Iran-US CT, national authorities are now granted a wide margin of appreciation in relation to the public purpose involved in the adoption of the expropriatory measure. And like the Iran-US CT, arbitrations instituted under 
investment codes, investment agreements, and BITs have followed a sole-effect approach, as a general rule. They normally apply the standard of substantial and permanent deprivation, derived from actions or omissions. This means, the destruction of the ability of the foreign investor to use, enjoy and dispose his property.

NAFTA arbitrations originally adopted the sole-effect rule too. But when expropriation claims started being lodged against the US and other developed states, the international minimum standard strongly advocated by these countries became more than suspicious: it became undesirable. The Trade Promotion Act of the US was enacted in 2002, shortly after the award in Metalclad was issued. This statute openly declared that one of the main negotiating objectives of the US is to ensure a national treatment standard for anyone investing within its borders. For that purpose, the guidelines domestically developed by US courts were included in its treaties. The police-powers rule had not been adopted in a judicial decision since Sea-Land, the Iran-US CT case of 1984. It was applied again in 2005 and 2006, by Methanex and Saluka, respectively. The same year of the latter, Canada concluded a BIT which closely resembles the terms of US treaties. Before these international agreements, only the Harvard Draft, the OECD Draft Convention and the Third Restatement had timidly incorporated a police-powers solution to the question of intent. In other words, no treaty had done so.

Although the police-powers rule is still exceptional in investment treaty arbitrations, even in those instituted under NAFTA, its eventual application has driven claimants to other compensable measures included in BITs and EIAs. Among these, foreign investors have mostly resorted to FET, a clause which complements 
the protection against expropriation. This absolute standard forms part of the minimum treatment guaranteed in investment treaties since the 1960s. As with indirect takings, the definition of FET does not answer the threshold question. The distinction between non-compensable regulatory measures and breaches to this clause, entitling the foreign investor to damages, can only be found on a case-by-case basis. International arbitral panels have identified certain elements which should guide the decision-maker's assessment. These elements include due process; nondiscrimination; due diligence; the respect for legitimate expectations; transparency; and good faith. The overarching obligation comprising them all is the duty of procedural propriety in the treatment of the alien. This is an obligation de moyens, rather than an obligation the résultat, for it is not the justice of this treatment that will be guaranteed by FET, but its fairness.

Unlike other measures affecting property rights under the Claims Settlement Declaration of the Iran-US CT, FET is a precise treaty standard which cannot be equated to any interference short of taking. Procedural propriety is also relevant with regards to the law of expropriation. Restricted in this case to the obligations of due process and the respect for legitimate expectations, the concept of fairness must aid the decision-maker at the moment of establishing whether a taking was lawful and whether an indirect expropriation had occurred, respectively. Besides this circumscribed obligation de moyens of procedural propriety, the protection against expropriation also imposes on the host-state an obligation the résultat. And the main guideline to its compliance is still the substantial deprivation of the alien, i.e., the effect of the measure in his property. 
Even though the threshold question of indirect expropriation involves important economical, political and social aspects, it is primarily a legal issue. This problem cannot be reduced to a policy-oriented choice between favouring the foreign investor or the host-state. Being a problem of law, the analysis of indirect takings must start from this standpoint. The power of national authorities to adopt sovereign measures should be appraised against the international minimum standard to which states have consented to in an express or implied form. This standard of treatment, first described in the Neer case, has certainly evolved since the 1920s. Treaties have codified and progressively developed the customary protection of foreigners, an essential part of which is the international law of expropriation. Its norms recognise the right of the host-state to take foreign investments, a right which must be exercised in conformity with four requirements. Public purpose is one of them. It is meant to avoid openly abusive measures, adopted for purely private reasons. The payment of compensation in Hull's terms, to the affected individual or legal entity, is another one. The sole-effect rule guarantees that this compensation is paid every time a foreigner is substantially deprived of his investment. These norms on the protection of aliens provide legal certainty to foreign investors, as well as host-states. In them, police-powers is an exception, not the rule.

It took several decades to achieve an agreement in the international society regarding the protection of aliens. This consensus can be found in the network of BITs and EIAs in force. The question is for how long. The absolute minimum standard of treatment, on which it is based, was initially advocated by the US with the support of Western-European states. Their multiple interventions in Latin America led to the Calvo doctrine, which proposed a relative standard of national 
treatment for all investors in the host-state, whether alien or not. The long-standing conflict that ensued is far from settled. The minimum standard continues to be threatened by its counterpart, the national treatment. This time, mostly advocated not by Latin American or African or Asian states, but by the US and Western European countries. Ironically, the national agendas currently pursued by developed states are not different from those pursued by developing countries some years ago. New BITs and EIAs have included a police-powers rule aimed at transforming the international standard of treatment into a national one. This policy not only threatens the international law of expropriation. Other compensable measures under BITs and EIAs might be assessed against this background in the future. And then, the international protection of aliens itself will be threatened. 


\section{Bibliography}

\section{Books}

1. Aldrich, G, The Jurisprudence of the Iran-United States Claims Tribunal (1996).

2. Allen, T, Property and The Human Rights Act 1998 (2005).

3. Avanessian, A, Iran-United States Claims Tribunal in Action (1993).

4. Beveridge, F, The Treatment and Taxation of Foreign Investment under International Law (2000).

5. Birnie, P, and Boyle, A, International Law \& the Environment (2002).

6. Bishop, R, Crawford, J, and Reisman, M, Foreign Investment Disputes. Cases, Materials and Commentary (2005).

7. Brower, C, and Brueschke, J, The Iran-United States Claims Tribunal (1998).

8. Boyle, A, and Chinkin, C, The Making of International Law (2006).

9. Brownlie, I, Principles of Public International Law (2003).

10. Calvo, C, Le Droit International Théorique et Pratique (1896).

11. Carreau, D, and Juillard, P, Droit International Économique (2003).

12. Cassese, A, International Law (2005).

13. Cassese, A, International Law in a Divided World (1994).

14. Clayton, R, and Tomlinson, H, The Law of Human Rights (2000).

15. Comeaux, P, and Kinsella, N, Protecting Foreign Direct Investment under International Law. Legal Aspects of Political Risk (1996). 
16. Crawford, J, The International Law Commission's Articles on State Responsibility. Introduction, Text and Commentaries (2005).

17. Davidson, S, The Inter-American Human Rights System (1997).

18. Dolzer, R, and Stevens, M, Bilateral Investment Treaties (1995).

19. Dugard, J, International Law. A South African Perspective (2000).

20. Fletcher, G, and Sheppard, S, American Law in a Global Context. The Basics (2005).

21. Harris, D, O'Boyle, M, and Warbrick, C, Law of the European Convention on Human Rights (1995).

22. Higgins, R, Problems \& Process. International Law and How We Use It (1994).

23. Ignatieff, M, The Lesser Evil. Political Ethics in an Age of Terror (2005).

24. Jennings, R and Watts, A, Oppenheim's International Law (1996).

25. Lowenfeld, A, International Economic Law (2003).

26. Malanczuk, P, Akehurst's Modern Introduction to International Law (1997).

27. Matsushita, M, Schoenbaum, T, and Mavroidis, $\mathrm{P}$, The World Trade Organization. Law, Practice, and Policy (2004).

28. Merrills, J, and Robertson, A, Human Rights in Europe. A Study of the European Convention on Human Rights (2001).

29. Mouri, A, The International Law of Expropriation as Reflected in the Work of the Iran-U.S. Claims Tribunal (1994). 
30. Mowbray, M, Cases and Materials on the European Convention on Human Rights (2007).

31. Muchlinski, P, Multinational Enterprises and the Law (1995).

32. Ovey, C, and White, R, Jacobs and White, The European Convention on Human Rights (2006).

33. Ridruejo, $\mathrm{P}$, Curso de Derecho Internacional y Organizaciones Internacionales (2000).

34. Paulsson, J, Denial of Justice in International Law (2005).

35. Quataert, D, The Ottoman Empire 1700-1922 (2006).

36. Rawls, J, A Theory of Justice (2005).

37. Redfern, A, and Hunter, M, Law and Practice of International Commercial Arbitration (2004).

38. Robertson, A, and Merrills, J, Human Rights in the World (1996).

39. Sands, P, Lawless World. America and the Making and Breaking of Global Rules (2005).

40. Seidl-Hohenveldern, I, International Economic Law (1992).

41. Schrijver, N, Sovereignty over Natural Resources. Balancing Rights and Duties (1997).

42. Shea, D, The Calvo Clause: A Problem of Inter-American and International Law and Diplomacy (1955).

43. Shihata, I, Legal Treatment of Foreign Investment: The World Bank Guidelines (1993).

44. Sornarajah, M, The International Law on Foreign Investment (2004).

45. Trayner, J, Latin Maxims and Phrases (1986). 
46. Van Dijk, P, and Van Hoof, G, Theory and Practice of the European Convention on Human Rights (1998).

47. White, G, Nationalisation of Foreign Property (1961).

48. Zweigert, K, and Kötz, H, Introduction to Comparative Law (1998).

\section{Articles}

1. Akpan, G, 'The Investment Provisions of the United States-Singapore Free Trade Agreement and the NAFTA. Old Wine in a New Skin or Something Else?', (2005) 6/VI JWIT 873.

2. Aldrich, G, 'What Constitutes a Compensable Taking: The Decisions of the Iran-United States Claims Tribunal', (1994) 88 AJIL 585.

3. AlQurashi, Z, 'Indirect Expropriation in the Field of Petroleum', (2004) 5/VI JWIT 897.

4. Anderson, D, 'Compensation for Interference with Property', (1999) 4/VI Eur. HRLR 543.

5. Appleton, B, 'Regulatory Takings: The International Law Perspective', (2003)11 NYU ELJ 35.

6. Been, V, and Beauvais, J, 'The Global Fifth Amendment: NAFTA's Investment Protection and the Misguided Quest for an International “Regulatory Takings" Doctrine', (2003) 78 NYU LR 30.

7. Bernardini, P, 'Investment Protection under Bilateral Investment Treaties and Investment Contracts', (2001) 2/II JWIT 235. 
8. Bowett, D, 'State Contracts with Aliens: Contemporary Developments on Compensation for Termination or Breach', (1988) 59 BYIL 49.

9. Brower, C, 'Current Developments in the Law of Expropriation and Compensation: A Preliminary Survey of Awards of the Iran-United States Claims Tribunal', (1987) 21 IL 639.

10. Brunetti, M, 'Indirect Expropriation in International Law', (2003) 5/III FORUM 150.

11. Brunetti, M, 'The Iran-United States Claims Tribunal, NAFTA Chapter 11, and the Doctrine of Indirect Expropriation', (2001) 2 Chic. JIL 203.

12. Christie, G, 'What Constitutes a Taking of Property under International Law?', (1962) BYIL 307.

13. Chinkin, C, 'The Challenge of Soft Law: Development and Change in International Law', (1989) 38/IV ICLQ 850.

14. Commission, J, 'Precedent in Investment Treaty Arbitration. A Citation Analysis of a Developing Jurisprudence', (2007) 24/II JIA 129.

15. Dalrymple, C, 'Politics and Foreign Direct Investment: The Multilateral Investment Guarantee Agency and the Calvo Clause', (1996) 29 Corn. ILJ 161.

16. Dolzer, R, 'Fair and Equitable Treatment: A Key Standard in Investment Treaties', (2005) 39 IL 87.

17. Dolzer, R, 'Indirect Expropriations: New Developments?', (2003) 11 NYU ELJ 64.

18. Dolzer, R, 'Indirect Expropriation of Alien Property', (1986) 1/I ICSID Rev. 41. 
19. Dolzer, R, 'New Foundations of the Law of Expropriation of Alien Property', (1981) 75/III AJIL 553.

20. Dolzer, R, and Bloch, F, 'Indirect Expropriation: Conceptual Realignments?', (2003) 5/III FORUM 155.

21. Dunn, F, 'International Law and Private Property Rights', (1928) 28 Colum. LR 166.

22. Elkins, Z, Guzman, A, and Simmons, B, 'Competing for Capital: The Diffusion of Bilateral Investment Treaties, 1960-2000', (2008) 1 UILR 265.

23. Escobar, A, 'Introductory Note on Bilateral Investment Treaties Recently Concluded by Latin American States', (1996) 11/I ICSID Rev. 86.

24. Fortier, Y, and Drymer, S, 'Indirect Expropriation in the Law of International Investment: I Know It When I See It, or Caveat Investor', (2004) 19/II ICSID Rev. 293.

25. Francioni, F, 'Compensation for Nationalisation of Foreign Property: The Borderline between Law and Equity', (1975) 24/II ICLQ 255.

26. Garcia-Mora, M, 'The Calvo Clause in Latin American Constitutions and International Law', (1950) 33/IV MLR 205.

27. Geiger, R, 'Regulatory Expropriations in International Law: Lessons from the Multilateral Agreement on Investment', (2003) 11 NYU ELJ 94.

28. Gibson, C, and Drahozal, C, 'Iran-United States Tribunal Precedent in Investor-State Arbitration', (2006) 23/VI JIA 521. 
29. Graham, E, 'Regulatory Takings, Supernational Treatment, and the Multilateral Agreement on Investment: Issues Raised by Nongovernmental Organizations', (1998) 31 Corn. ILJ 599.

30. Graham, F, 'The Calvo Clause: Its Current Status as a Contractual Renunciation of Diplomatic Protection', (1970) 6 Tex. ILF 289.

31. Gutbrod, M, and Hindelang, S, 'Externalization of Effective Legal Protection against Indirect Expropriation. Can the Legal Order of Developing Countries Live up to the Standards Required by International Investment Agreements? A Disenchanting Comparative Analysis', (2006) 7/I JWIT 59.

32. Guzman, A, 'Why LDCs Sign Treaties that Hurt Them: Explaining the Popularity of Bilateral Investment Treaties', (1998) 38 Virg. JIL 639.

33. Heiskanen, V, 'The Contribution of the Iran-United States Claims Tribunal to the Development of the Doctrine of Indirect Expropriation', (2003) 5/III FORUM 176.

34. Heiskanen, H, 'The Doctrine of Indirect Expropriation in Light of the Practice of the Iran-United States Claims Tribunal', (2007) 8/II JWIT 215.

35. Herz, J, 'Expropriation of Foreign Property', (1941) 35 AJIL 243.

36. Higgins, R, 'The Taking of Property by the State: Recent Developments in International Law', (1982) 176/III RdC 259.

37. Hillgenberg, H, ‘A Fresh Look at Soft Law', (1999) 10/III EJIL 499. 
38. Hindelang, S, 'Bilateral Investment Treaties, Custom and a Healthy Investment Climate - The Question of Whether BITs Influence Customary International Law Revisited', (2004) 5/V JWIT 769.

39. Juillard, P, ‘MAI : A European View', (1998) 31 Corn. ILJ 477.

40. Kantor, M, 'Fair and Equitable Treatment: Echoes of FDR's CourtPacking Plan in the International Law Approach Towards Regulatory Expropriation', (2006) 5 LPICT 231.

41. Kishaiyian, B, 'The Utility of Bilateral Investment Treaties in the Formulation of Customary International Law', (1994) 14 NW JILB 327. 42. Klabbers, J, 'The Redundancy of Soft Law', (1996) 65 Nor. JIL 167.

43. Kriebaum, U, 'Partial Expropriation', (2007) 8/I JWIT 69.

44. Kriebaum, U, 'Regulatory Takings: Balancing the Interests of the Investor and the State', (2007) 8/V JWIT 717.

45. Kunoy, B, 'Developments in Indirect Expropriation Case Law in ICSID Transnational Arbitration', (2005) 6/III JWIT 467.

46. Kunoy, B, 'The Notion of Time in ICSID's Case Law on Indirect Expropriation', (2006) JIA 337.

47. Loppacher, L, and Kerr, K, 'Investment Rules. The U.S. Agenda in Bilateral Trade Agreements', (2006) 7/I JWIT 39.

48. Lowenfeld, A, 'Investment Agreements and International Law', (2003) 42 Colum. JTN 123.

49. Madalena, I, 'Foreign Direct Investment and the Protection of the Environment: the Border between National Environmental Regulation and Expropriation', (2003) 12/III Eur. ELR 70. 
50. Maniruzzaman, A, 'Expropriation of Alien Property and the Principle of Non-Discrimination in International Law of Foreign Investment: An Overview', (1998) 8 JTLP 57.

51. Mann, F, 'British Treaties for the Promotion and Protection of Investments', (1981) BYIL 241.

52. Mann, F, 'Outlines of a History of Expropriation', (1959) 75 LQR 188.

53. I Marboe, 'Compensation and Damages in International Law. The Limits of the 'Fair Market Value", (2006) 7/V JWIT 723.

54. Metzger, S, 'Multilateral Conventions for the Protection of Private Foreign Investment', (1960) 9 JPL 133.

55. Mountfield, H, 'Regulatory Expropriations in Europe: The Approach of the European Court of Human Rights', (2003) 11 NYU ELJ 136.

56. Muchlinski, P, 'The Rise and Fall of the Multilateral Agreement on Investment: Where Now?', (2000) 34 IL 1033.

57. Neumayer, E, and Spess, L, 'Do Bilateral Investment Treaties Increase Foreign Direct Investment to Developing Countries?', (2005) LSE Research Online.

58. Newcombe, A, 'The Boundaries of Regulatory Expropriation in International Law', (2005) 20/I ICSID Rev. 1.

59. Newcombe, A, 'Sustainable Development and Investment Treaty Law', (2007) 3/VIII JWIT 357.

60. Norton, P, 'A Law of the Future or a Law of the Past? Modern Tribunals and the International Law of Expropriation', (1991) 85 AJIL 474. 
61. Orrego Vicuña, F, 'Carlos Calvo, Honorary NAFTA Citizen', (2002) $11 N Y U E L J 19$.

62. Orrego Vicuña, F, 'Regulatory Authority and Legitimate Expectations: Balancing the Rights of the State and the Individual under International Law in a Global Society', (2003) 5/III FORUM 188.

63. Parra, A, 'Principles Governing Foreign Investment, as Reflected in National Investment Codes', (1992) 7/II ICSID Rev. 428.

64. Paulsson, J, 'Arbitration Without Privity", (1995) 10/II ICSID Rev. 232.

65. Pellonpää, M, and Fitzmaurice, M, 'Taking of Property in the Practice of the Iran - United States Claims Tribunal', (1988) 19 Neth. YIL 53.

66. Picciotto, S, 'Linkages in International Investment Regulation: The Antinomies of the Draft Multilateral Agreement on Investment', (1998) 19 UPenn. JIEL 731.

67. Reisman, M, and Sloane, R, 'Indirect Expropriation and its Valuation in the BIT Generation', (2003) 74 BYIL 115.

68. Root, E, 'The Basis of Protection to Citizens Residing Abroad', (1910) 4 AJIL 517.

69. Ruiz Fabri, H, 'The Approach Taken by the European Court of Human Rights to the Assessment of Compensation for "Regulatory Expropriations" of the Property of Foreign Investors', (2003) $11 \mathrm{NYU}$ ELJ 148 .

70. Sacerdoti, G, 'Bilateral Treaties and Multilateral Instruments on Investment Protection', (1997) 269 RdC 251. 
71. Sacerdoti, G, 'The Admission and Treatment of Foreign Investment under Recent Bilateral and Regional Treaties', (2000) 1/I JWIT 105.

72. Salacuse, J, 'BIT by BIT: The Growth of Bilateral Investment Treaties and Their Impact on Foreign Investment in Developing Countries', (1990) 24/III IL 655.

73. Salacuse, J, and Sullivan, N, 'Do BITs Really Work: An Evaluation of Bilateral Investment Treaties and Their Grand Bargain', (2005) 46/I Harv. ILJ 67.

74. Sampliner, G, 'Arbitration of Expropriation Cases under U.S. Investment Treaties - A Threat to Democracy or the Dog That Didn't Bark?', (2003) 18/I ICSID Rev. 1.

75. Schill, S, 'Fair and Equitable Treatment under Investment Treaties as an Embodiment of the Rule of Law', (2006) 6 ILJWP 1.

76. Schreuer, C, 'Fair and Equitable Treatment in Arbitral Practice', (2005) 6/III JWIT 357.

77. Schwarzenberger, G, 'The Abs-Shawcross Draft Convention on Investments Abroad: A Critical Commentary', (1960) 9 JPL 147.

78. Sedigh, H, 'What Level of Host State Interference Amounts to a Taking under Contemporary International Law', (2001) 2/II JWIT 631.

79. Shenkman, E, 'Could Principles of Fifth Amendment Takings Jurisprudence be Helpful in Analyzing Regulatory Expropriation Claims under International Law?', (2003) 11 NYU ELJ 174.

80. Sohn, L, and Baxter, R, 'Responsibility of States for Injuries to the Economic Interests of Aliens', (1961) 55 AJIL 545. 
81. Sornarajah, M, 'Power and Justice in International Law', (1997) 1 SJICL 28.

82. Stumberg, R, 'Sovereignty by Subtraction: The Multilateral Agreement on Investment', (1998) 31 Corn. ILJ 491.

83. Tobin, J, and Rose-Ackerman, S, 'Foreign Direct Investment and the Business Environment in Developing Countries: the Impact of Bilateral Investment Treaties', (2004) 293 Yale LERP.

84. Tobin, J, and Rose-Ackerman, S, 'When BITs have some bite', (2006) Yale LSDWP.

85. Tschofen, F, 'Multilateral Approaches to the Treatment of Foreign Investment', (1992) 7/II ICSID Rev. 384.

86. Vallianatos, M, 'De-Fanging the MAI', (1998) 31 Corn. ILJ 713.

87. Vandevelde, K, 'The Bilateral Investment Treaty Program of the United States', (1988) 21 Corn. ILJ 201.

88. Vandevelde, K, 'U.S. Bilateral Investment Treaties: the Second Wave', (1993) 14 Mich. JIL 621.

89. Vasciannie, S, 'The Fair and Equitable Treatment Standard in International Investment Law and Practice', (1999) 70 BYIL 99.

90. von Mehren, R, and Kourides, P, 'International Arbitration Between States and Foreign Private Parties: The Libyan Nationalization Cases', (1981) 75 AJIL 476.

91. Waelde, T, 'Energy Charter Treaty-based Investment Arbitration. Controversial Issues', (2004) 5/III JWIT 373. 
92. Waelde, T, and Kolo, A, 'Environmental Regulation, Investment Protection and 'Regulatory Taking' in International Law', (2001) 50/IV ICLQ 811 .

93. P Weil, 'Towards Relative Normativity in International Law?', (1983) 77 AJIL 413.

94. Weiner, A, 'Indirect Expropriations: The Need for a Taxonomy of “Legitimate” Regulatory Purposes', (2003) 5/III FORUM 166.

95. Wetsberg, J, 'Applicable Law, Expropriatory Takings and Compensations in Cases of Expropriation: ICSID and Iran - United States Claims Tribunal Case Law Compared', (1993) 8/I ICSID Rev. 1.

96. Westberg, J, 'Compensation in Cases of Expropriation and Nationalization: Awards of the Iran-United States Claims Tribunal', (1990) 5/II ICSID Rev. 256.

97. Weston, B, “Constructive Takings' under International Law: A Modest Foray into the Problem of 'Creeping Expropriation', (1975) 16/I Virg. JIL 103.

\section{Contributions to compilations \& edited volumes}

1. American Law Institute, Restatement of the Law Third. The Foreign Relations Law of the United States (1987).

2. Benedek, W, 'Drago-Porter Convention (1907)', in Bernhardt, R, (ed.), EPIL (1992), Vol. I. 
3. Blackaby, N, and Paradell, L, 'Investment Treaty Arbitration', in Tackaberry, J, and Marriott, A, (eds.), Bernstein's Handbook of Arbitration and Dispute Resolution Practice (2003), Vol. I.

4. Blumemwitz, D, 'Treaties of Friendship, Commerce and Navigation', in Bernhardt, R, (ed.), EPIL (2000), Vol. IV.

5. Boyle, A, 'Soft Law in International Law-Making', in M Evans (ed.), International Law (2006).

6. Brower, B, 'Natural Resources, Sovereignty over', in Bernhardt, R, (ed.), EPIL (1997), Vol. III.

7. Buxbaum, R, and Riesenfeld, S, 'Investment Codes', in Bernhardt, R, (ed.), EPIL (1995), Vol. II.

8. Chinkin, C, 'Normative Development in the International Legal System', in Sheldon, D, (ed.), Commitment and Compliance. The Role of Non-Binding Norms in the International Legal System (2003).

9. Condorelli, L, 'Premier Protocole Additionel. Article 1', in L Pettiti, E Decaux and P Imbert (eds.), La Convention Europeénne des Droits de l'Homme (1999).

10. D'Amato, A, 'Good Faith', in R Bernhardt (ed.), EPIL (1995), Vol. II.

11. Davidson, S, 'The Civil and Political Rights Protected in the InterAmerican Human Rights System', in Harris, D, and Livingstone, S, (eds.), The Inter-American System of Human Rights (1998).

12. Dinstein, Y, 'Deprivation of Property of Foreigners under International Law', in Ando, N, et al (eds.), Liber Amicorum Judge Shigeru Oda (2002). 
13. Dolzer, R, 'Expropriation and Nationalization', in Bernhardt, R, (ed.), EPIL (1995), Vol. II.

14. Dolzer, R, 'Requisitions', in R Bernhardt (ed.), EPIL (2000), Vol. IV.

15. Dolzer, R, 'Sequestration', in R Bernhardt (ed.), EPIL (2000), Vol. IV.

16. Evans, M, (ed.), International Law (2004).

17. Evans, M, and Murray, R, (eds.), The African Charter on Human Rights and Peoples': the System in Practice, 1986-2000 (2002).

18. Garcia-Amador, F, 'Calvo Doctrine, Calvo Clause', in Bernhardt, R, (ed.), EPIL (1992), Vol. I.

19. Garner, B, (ed), Black's Law Dictionary (1999).

20. Gretton, G, 'The Protection of Property Rights', in A Boyle et al (eds.), Human Rights and Scots Law (2002).

21. Hartwig, M, 'Colonies and Colonial Régime', in Bernhardt, R, (ed.), EPIL (1992), Vol. I.

22. Heyns, C, 'Civil and Political Rights in the African Charter', in Evans, M, and Murray, R, (eds.), The African Charter on Human Rights and Peoples': the System in Practice, 1986-2000 (2002).

23. Houde, M-F, and Yannaca-Small, C, 'Relationships between International Investment Agreements', in OECD, Working Papers on International Investment (2004), Nr. 1.

24. Jaenicke, G, 'Havana Charter', in Bernhardt, R, (ed.), EPIL (1995), Vol. II.

25. M Janis, 'Equity in International Law', in Bernhardt, R, (ed), EPIL (1995), Vol. 2. 
26. Lachs, M, 'Pacta Sunt Servanda', in Bernhardt, R, (ed.), EPIL (1997), Vol. III.

27. Lillich, R, 'Lump Sum Agreements', in Bernhardt, R, (ed.), EPIL (1997), Vol. III.

28. Paulsson, J, and Douglas, Z, 'Indirect Expropriation in Investment Treaty Arbitrations', in Horn, N, (ed), Arbitrating Foreign Investment Disputes. Procedural and Substantive Legal Aspects (2004).

29. Petersmann, E, 'Charter of Economic Rights and Duties of States', in Bernhardt, R, (ed.), EPIL (1992), Vol. I.

30. Riesenfeld, S, 'Foreign Investments', in Bernhardt, R, (ed.), EPIL (1995), Vol. II.

31. Riesenfeld, S, and Caron, D, 'United States-Iran Agreement of January 19, 1981 (Hostages and Financial Agreements)', in Bernhardt, R, (ed.), EPIL (2000), Vol. IV.

32. Rubins, R, 'The Notion of 'Investment' in International Investment Arbitration', in Horn, N, (ed.), Arbitrating Foreign Investment Disputes. Procedural and Substantive Legal Aspects (2004).

33. Schreuer, C, 'The Concept of Expropriation under the ECT and other Investment Protection Treaties', in C Ribeiro (ed.), Investment Arbitration and the Energy Charter Treaty (2006).

34. Seidl-Hohenveldern, I, 'Aliens, Property', in Bernhardt, R, (ed.), EPIL (1992), Vol. I.

35. Silagi, M, 'Preferential Claims against Venezuela Arbitration', in Bernhardt, R, (ed.), EPIL (1997), Vol. III. 
36. Steinberger, H, 'Sovereignty', in Berhardt, R, (ed.), EPIL (2000), Vol. IV.

37. Tomuschat, C, 'New International Economic Order', in Bernhardt, R, (ed.), EPIL (1997), Vol. III.

38. UNCTAD, Developments in International Investment Agreements in 2005 (2006).

39. UNCTAD, International Investment Agreements: Key Issues (2004), Vol. I.

40. UNCTAD, Investment Provisions in Economic Integration Agreements (2006).

41. UNCTAD, Latest Developments in Investor-State Dispute Settlement (2005).

42. UNCTAD, Recent Developments in International Investment Agreements (2005).

43. UNCTAD, The Entry into Force of Bilateral Investment Treaties (2006).

44. Vagts, D, 'Minimum Standard', in R Berhardt (ed.), EPIL (1997), Vol. III.

45. Waelde, T, 'Requiem for New International Economic Order', in Hafner, G, et al (eds.), Liber Amicorum I. Seidl-Hohenveldern (1998).

46. Wallace, D, 'Case Study under NAFTA: Lessons for the Wise?', in N Horn (ed), Arbitrating Foreign Investment Disputes. Procedural and Substantive Legal Aspects (2004). 
47. Yannaca-Small, C, 'Fair and Equitable Treatment Standard in International Investment Law', in OECD, Working Papers on International Investment (2004), Nr. 3.

48. Yannaca-Small, C, 'Indirect Expropriation' and the 'Right to Regulate' in International Investment Law', in OECD, Working Papers on International Investment (2004), Nr. 4. 